$\mathrm{Ma}-\mathrm{O}$ 


\section{HARVARD UNIVERSITY}

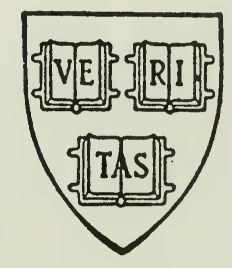

\section{LIBRARY}

$$
\text { OF THE }
$$

Museum of Comparative Zoology 


33,120

DEPARTMENT OF THE INTERIOR

UNITED STATES GEOLOGICAL SURVEY GEORGE OTIS SMITH, DIRECTOR

\title{
BULLETIN 361
}

\section{CENOZOIC MAMMAL HORIZONS OF WESTERN NORTH AMERICA}

\author{
BY \\ HENRY FAIRFIELD OSBORN
}

WITH

FAUNAL LISTS OF THE TERTIARY MAVIMALIA OF THE WEST

BY

WILLIAM DILLER MATTHEW

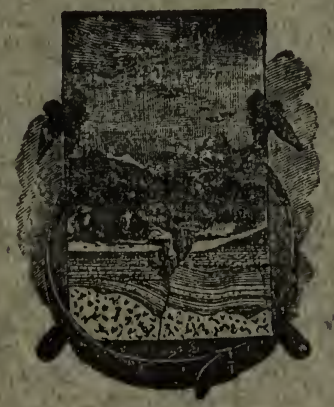

WASHINGTON

GOVERNMENT PRINTING OFFICE

1909 


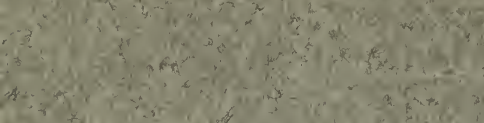

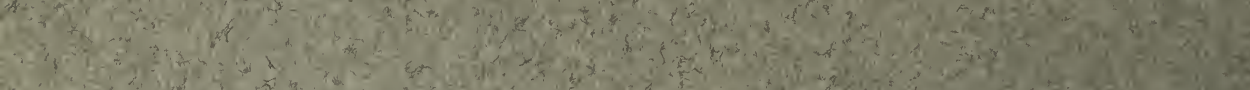

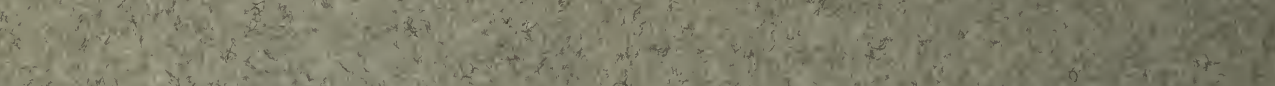

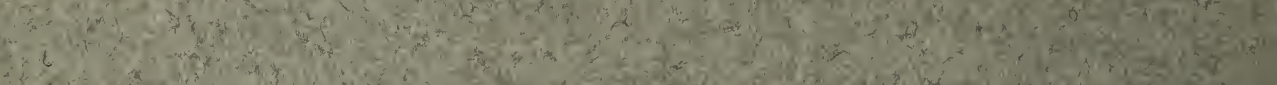
4.

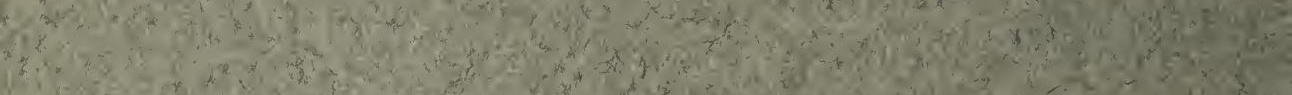

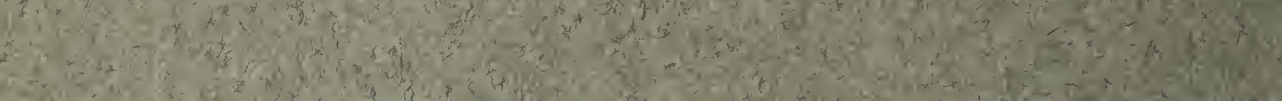

(2) (3) 4.

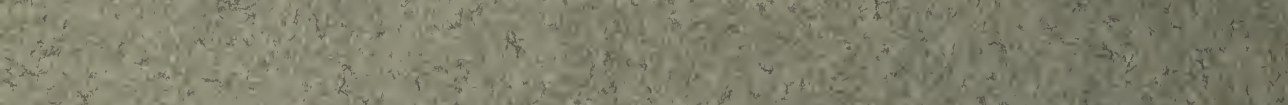
60 (3)

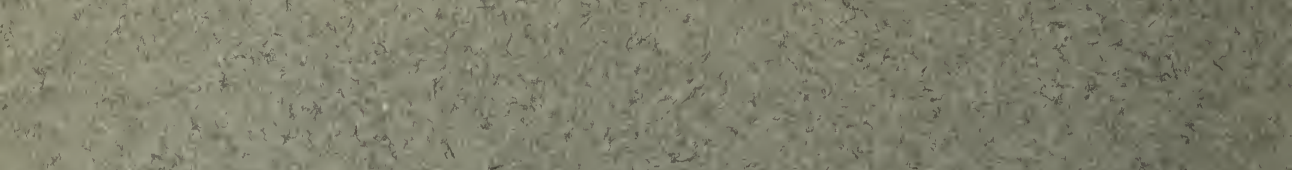

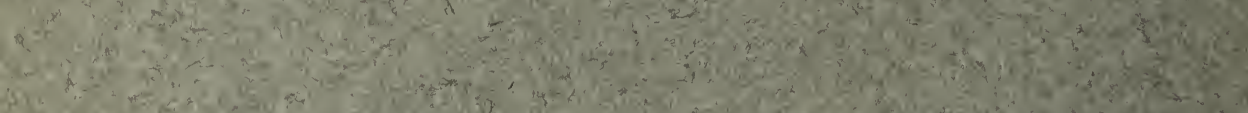

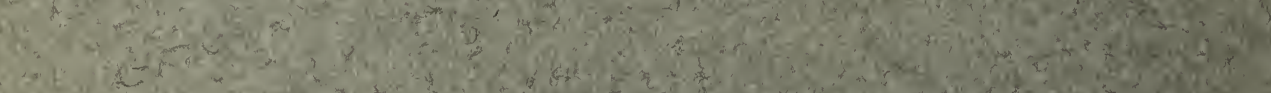

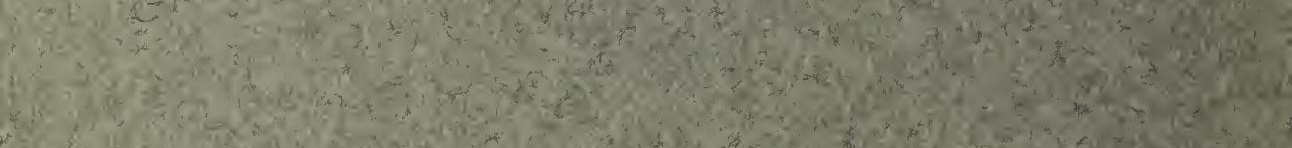
(6)

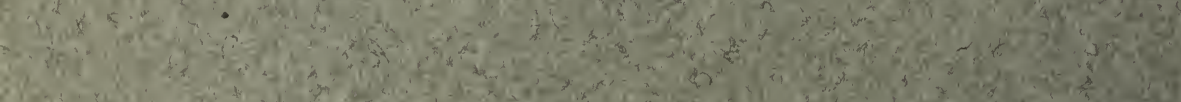
3.

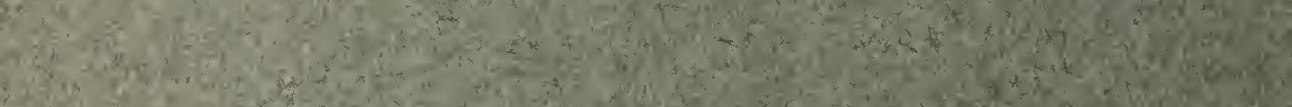

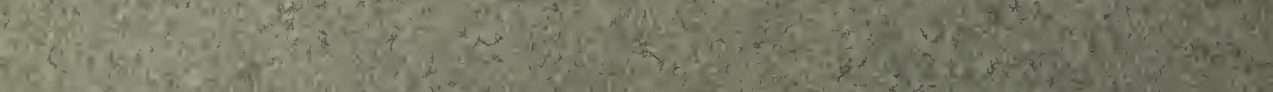

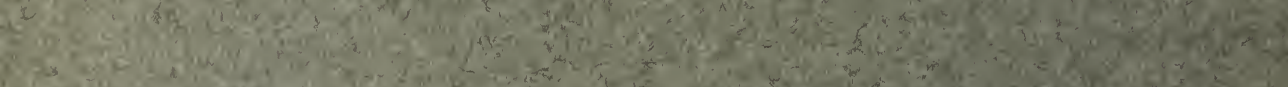

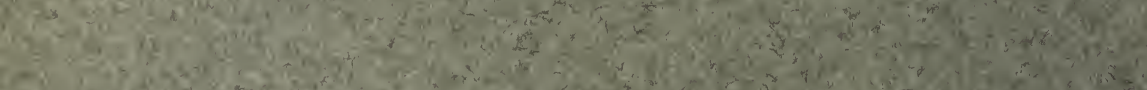
(a)

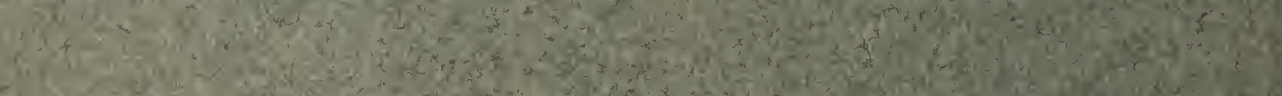
Exis

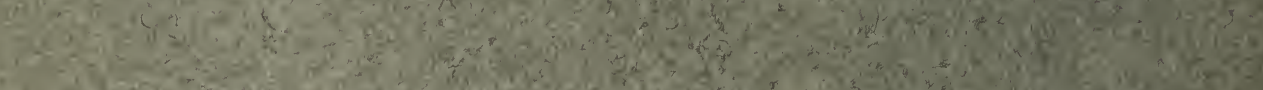

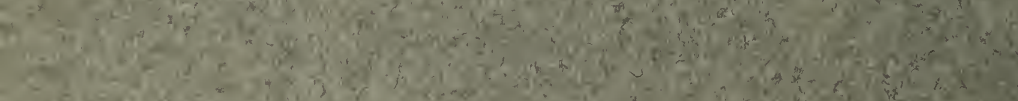


DEPARTMENT OF THE INTERIOR

UNITED STATES GEOLOGICAL SURVEY GEORGE OTIS SMITH, DIRECTOR

BULLETIN 361

\title{
CENOZOIC MAMIIAL HORIZONS OF WESTERN NORTH AVERICA
}

\author{
BY \\ HENRY FAIRFIELD OSBORN \\ WITII
}

FAUNAL LISTS OF THE TERTIARY MAMMALIA OF THE WEST'

$13 Y$

WILLIAM DILLER MATTHEW

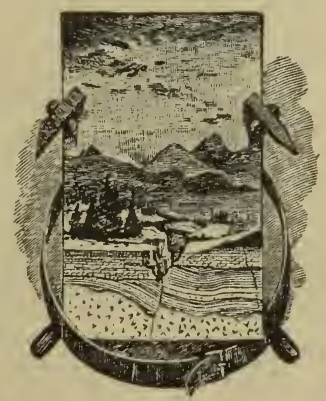

WASHINGTON

GOVERN IENT PRINTING OFEICE 1909 



\section{CONTENTS.}

Page.

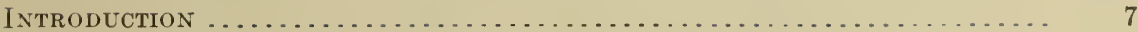

Formations and zones..................................

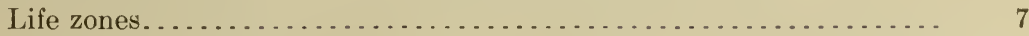

Geologic formations ................................. 7

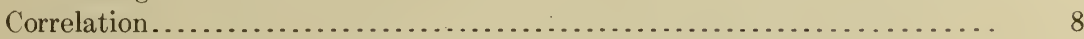

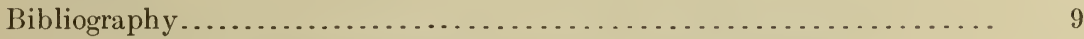

Chapter I. General geologic and climatic history of the Tertiary.......... 19

The Mountain Region.................................. 19

The Plains Region..................................... 20

Resemblances and contrasts between Mountain and Plains regions....... 21

Resemblances..................................... 21

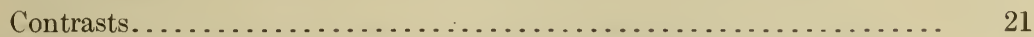

Geologic history of Mountain basin deposits of the Eocene and Oligocene. 24

Geologic history of the Great Plains deposits of the Oligocene to lower

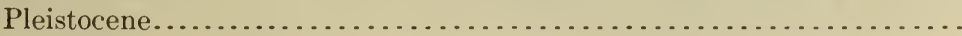

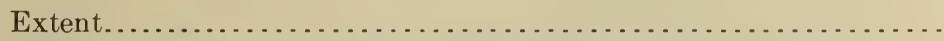

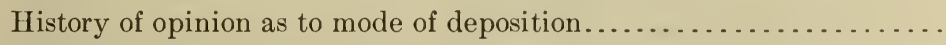

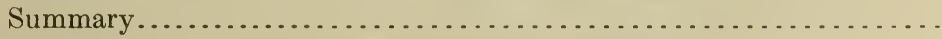

Chapter II. Time correlation of mammal-bearing horizons.............

The two grand problems.............................

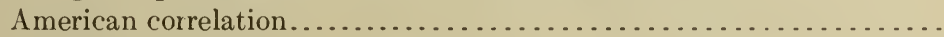

American and Eurasiatic correlation........................ 29

Methods of correlation................................ 30

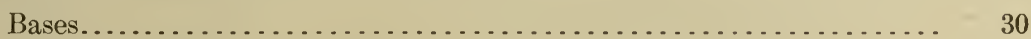

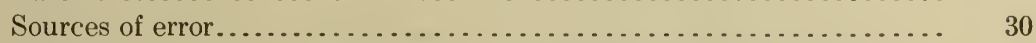

Preliminary correlation of the Eocene and Oligocene Mountain deposits... 31

Preliminary correlation of the Oligocene to lower Pleistocene Mountain and

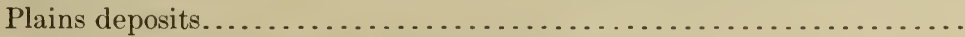

Chapter III. Western American Cenozoic horizons. . . . . . . . . . . . . . .

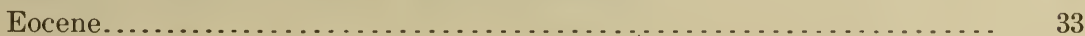

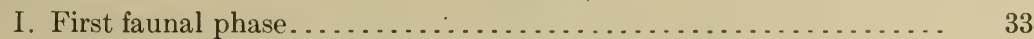

Post-Cretaceous or basal Eocene (étage Thanétien)........... 33

1. Puerco formation, Polymastodon zone............... 33

2. Torrejon formation; Pantolambda zone............. 34

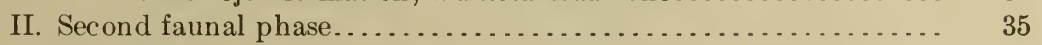

Lower Eocene (étages Sparnacien, Yprésien)................ 36

3. Wasatch formation; Coryphodon zone................ 36

3a. Wasatch of the Bighorn basin .................. 41

III. Third faunal phase............................. 42

Lower to middle Eocene (étages Yprésien, Lutétien inférieur).... 43

4. Wind River formation; Lambdotherium and Bathyopsis zones...................................

4a. Huerfano formation; Lambdotherium and ? Uintatherium zones. 
Chapter III. Western American Cenozoic horizons-Continued.

Page.

Eocene-Continued.

III. Third faunal phase-Continued.

Middle Eocene (étages Lutétien supérieur, Bartonien)

5. Bridger formation; Orohippus and Uintatherium zones.... 50

Middle to upper Eocene (étage Bartonien)............... 53

Later Eocene deposits of IVashakie basin; Uintatherium and

Eobasileus zones...............................

Upper Eocene (étages Bartonien in part, Ludien (Ligurien) in

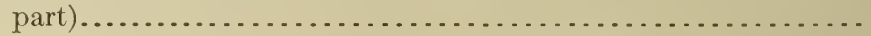

7. Later Eocene deposits of Uinta basin; Uintatherium, Eobasileus, and Diplacodon zones......................

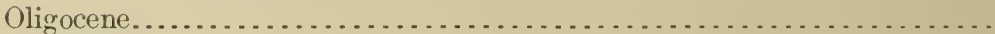

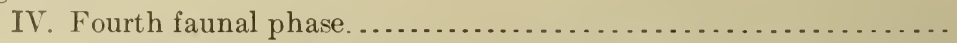

Lower Oligocene, White River group of Hayden (étage Sannoisien [Tongrien inférieur]) ............................. 60

8. Chadron formation; Titanotherium zone............. 60

Middle Oligocene (étage Stampien [Tongrien supérieur])......... 62

9. Lower part of Brule clay; Oreodon zone and "Metamynodon sandstones"....................................

Upper Oligocene, first phase..........................

10. Upper part of Brule clay; Leptauchenia zone and "Protoceras sandstones"............................ 63

Oregon Cenozoic formations......................... 64

Résumé of the Oregon deposits as a whole............ 64

John Day formation.......................... 64

Upper Oligocene, second phase....................... 67

11. Niddle part of John Day formation; Diceratherium zone (also upper part of John Day, transitional)............ 67

Upper Oligocene, latest phase........................ 68

12. Upper part of John Day formation; Promerycochœrus zone.. 68

Miocene............................................ 70

IV. Fourth faunal phase-Continued ....................... 70

Lower Miocene (étages Aquitanien, Burdigalien) ... . . . . . . . . $\quad 70$

13. Arikaree formation; Promerycochœrus zone............ 70

General features.............................. $\quad 70$

Westerly section............................. 73

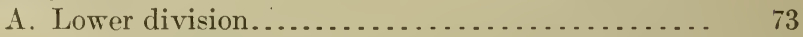

(a) Gering formation..................... $\quad 73$

(b) Monroe Creek formation ............ . . . . . $\quad 73$

(c) Harrison formation, Hatcher............... 73

(d) Harrison formation, Agate Spring quarry .... 74

B. Upper division........................... 74

(e) Upper part of Harrison formation......... $\quad 74$

Easterly section............................. 74

A. Lower part of Rosebud..................... $\quad 75$

B. Upper part of Rosebud.................. $\quad 75$

V. Fifth faunal phase................................. 76

Middle Miocene (étages Helvétien, Sarmatien, Tortonien)....... 76

Faunal changes............................... $\quad 76$

14. Deep River sequence; Ticholeptus zone............. 76

Upper Miocene (étage Pontien) ........................... $\quad 79$

15. Ogalalla formation (in part); Procamelus zone........ 79 
Chapter III. Western American Cenozoic horizons-Continued.

Miocene-Continued.

V. Fifth faunal phase-Continued.

Last phase of Miocene of first phase o. Pliocene (étages Pontien, Messinien)

16. Ogalalla formation (in part); Peraceras zone.......... 80

16a. Rattlesnake formation of John Day Valley, Oregon...... 81

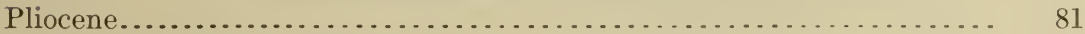

VI. Sixth faunal phase......................................... 82

Middle Pliocene or second phase (étage Astien)............. 82

17. Blanco formation; Glyptotherium zone............... 82

Upper Pliocene or lower Pleistocene..................... 83

18. Elephas imperator zone.......................... 83

Pleistocene................................................. 84

VII. Seventh faunal phase.............................. 84

Lower Pleistocene (preglacial) ......................... 84

19. Equus zone................................. 85

Middle Pleistocene (glacial) .......................... 86

General characters................................ 86

Early phases.................................. 87

Subsequent phases............................... 88

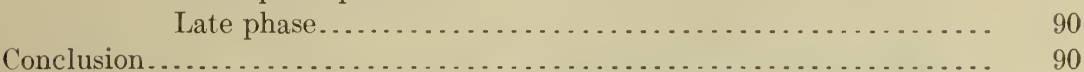

Appendix. Faunal lists of the Tertiary Mammalia of the West, by W. D.

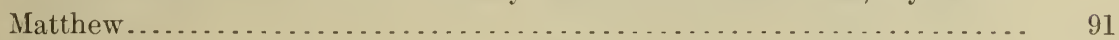

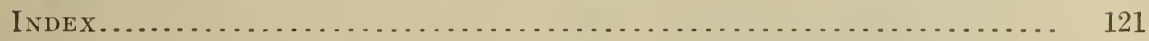




\section{ILLUSTRATIONS.}

Plate I. Map of the United States, showing general Mountain and Great Plains regions, also location of the principal formations, sections, and

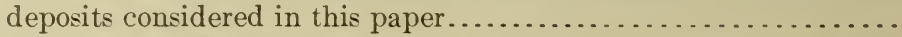

II. Oligocene and Miocene exposures in South Dakota, northwestern

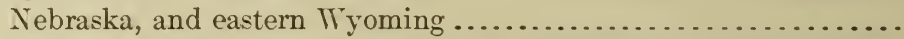

III. Idealized bird's-eye view of the great Badlands of South Dakota, showing channel and overflow deposits in the Oligocene and lower

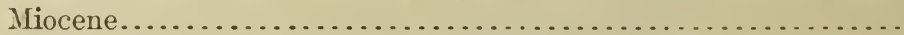

FIG. 1. Composite section of the Tertiary deposits of the West.............

2. Map of southwestern Wyoming and northern Utah, showing partial areas of the Wasatch, Wind River, Bridger, and Uinta formations....

3. Composite columnar section of the Wasatch formation of Bighorn Basin..

4. Columnar section showing the relations of the typical Wasatch section, including the Knight formation, to the overlying and underlying

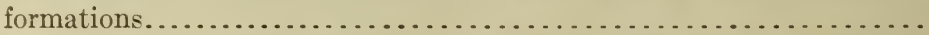

5. Columnar section of the Wind River basin, based on the descriptions

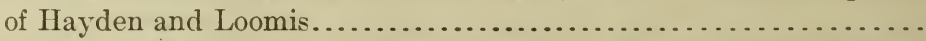

6. Columnar section of the Bridger formation, Henrys Fork, western Tyoming............................................ 51

7. Preliminary columnar section of the "liashakie formation," "Wyoming... 53

8. Columnar section of the Uinta formation, northern Utah........... 5.5

9. Diagrammatic section of the White River group, South Dakota....... 62

10. Provisional correlation of some of the chief epicontinental OligocenePleistocene deposits and formations of the liest in which fossil mammals have been recorded . . . . . . . . . . . . . . . . . . . . . . . .

11. Columnar section of the John Day formation, Oregon . . . . . . . . . . . .

12. Columnar section of the Rosebud formation. . . . . . . . . . . . . . . .

13. Columnar section of the Gering, Monroe Creek, and Harrison formations, western Nebraska. . . . . . . . . . . . . . . . . . . . . . . .

14. Diagrammatic section of the Gering, Monroe Creek, and Harrison formations, western Nebraska.........................

15. Diagrammatic section of the Staked Plains (Llano Estacado), Texas, showing the relations of the "Clarendon," "Rock Creek," and

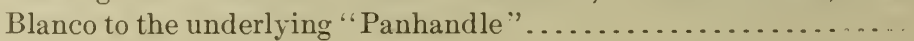




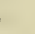




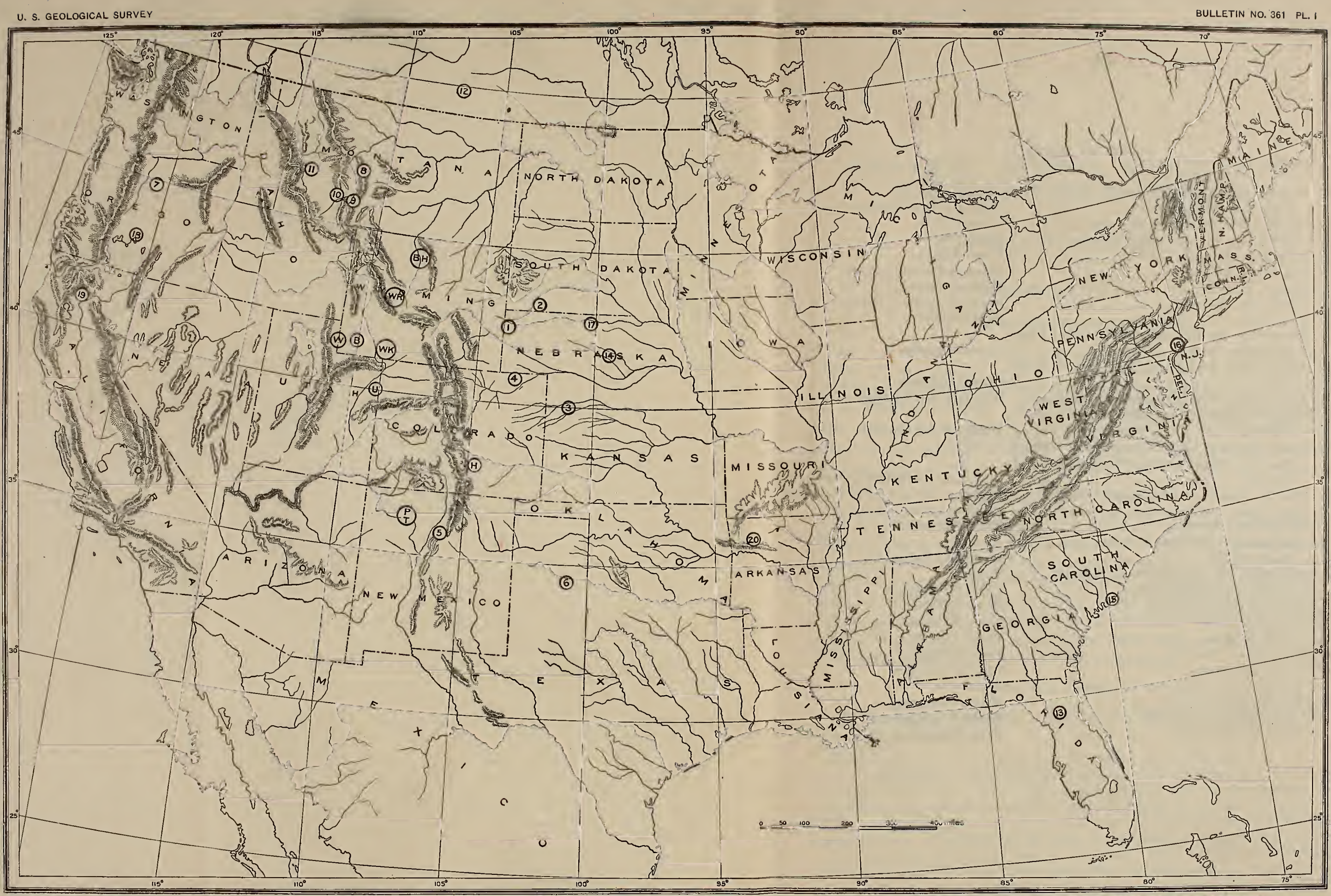

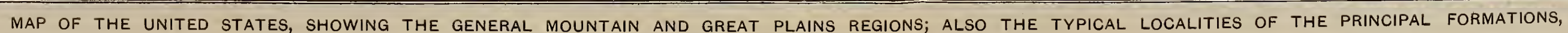
SECTIONS, AND DEPOSITS CONSIDERED IN THIS PAPER. 


\section{KEY TO PLATE I.}

PT-Puerco, Torrejon, and Wasatch of San Juan basin. New Mexico

BH-Wasatch of Bighorn Basin, Wyoming ...........

W-Wasatch (typical), Evanston, Wyoming..........

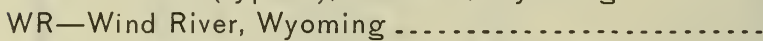

H-Huerfano, Colorado

B-Bridger, Wyoming

WK-"Washakie," Wyoming

U-Uinta, Utah

$12-$ White River deposits along Swift Current Creek, Assiniboia, Canada.

10-White River deposits along Pipestone Creek, Montana

2-Typical White River and Rosebud, South Dakota..

1-White River, Monroe Creek, and Harrison, Nebraska

4-Pawnee Buttes section ("Pawnee Creek," "Martin Canyon," "Cedar Creek," "Horsetail Creek"), Colorado

7-John Day, Mascall, and Rattlesnake, Oregon.

8- "Fort Logan" and Deep River, Montana

1 - "Flint Creek," Montana

6-"Panhandle," "Clarendon," Blanco, and "Rock Creek," Texas$$
\text { "Santa Fe marls," New Mexico. }
$$$$
\text { 9-"Madison Valley," Montana }
$$$$
\text { 3-"Republican River," Kansas...................... }
$$$$
\text { 13-"Archer," Florida........................... }
$$$$
\text { 14-"Loup River," Nebraska ....................... Up }
$$$$
\text { 18-Silver Lake, Oregon ....................... }
$$$$
\text { 15-Ashley River, South Carolina.................. }
$$$$
\text { 16-Port Kennedy, Pennsylvania.................. Mic.... }
$$$$
\text { 19-Potter Creek cave, California ................... Mic }
$$$$
\text { 20-Conard fissure, Arkansas. }
$$

Basal and lower Eocene.

Lower Eocene.

Lower Eocene.

Lower Eocene.

Lower and middle Eocene.

Middle Eocene.

Middle and upper Eocene.

Upper Eocene.

\section{Lover Oligocene.}

Lower Oligocene.

Oligocene and Miocene.

Oligocene and Miocene.

Oligocene to middle Miocene.

Oligocene, Miocene, and Pliocene. Lower and middle Miocene.

Middle Miocene.

Miocene to Pleistocene.

Miocene.

Upper Miocene.

Upper Miocene.

Lower Pliocene.

Lower Pliocene.

Upper Pliocene.

Lower Pleistocene.

Pleistocene.

Middle Pleistocene.

Middle Pleistocene.

Upper Pleistocene. 


\title{
CENOZOIC MAMMAL HORIZONS OF WESTERN NORTH AMERICA.
}

\author{
By Henry Fairfield Osborn.
}

\section{INTRODUCTION. \\ FORMATIONS AND ZONES.}

The main purpose of this paper is faunistic rather than geologic. Many of the geologic "groups" and "formations" referred to are still imperfectly defined and known, either as to geographic extent or as to lithologic content. Many of the geologic terms used are therefore not to be regarded as final. It should be clearly understood also that the geologic sections are largely diagrammatic and in most cases are not to be interpreted as giving a clue to the lithologic content.

\section{LIFE ZONES.}

It is proposed, according to the ruling of the International Geological Congress and the old practice of invertebrate paleontologists, to use the word "zone" for the faunistic levels of such geologic formations or groups as may be synchronized by the presence of certain distinctive animals. Thus we may speak of the Uintatherium zone of the upper Bridger formation or of the lower "Washakie." The word "beds," previously used in the same sense, is liable to cause confusion because it is used also for formations.

\section{GEOLOGIC FORMATIONS.}

A "formation" has been defined as follows by the United States Geological Survey:

In all classes of rocks the cartographic units shall be called formations.

The discrimination of sedimentary formations shall be based upon the local sequence of the rocks * * * and the geologist must select for the limitation of formations such horizons of change as will best express the geologic development and structure of the region and will give to the formations the greatest practical unity of constitution. In determining this unity of constitution all available lines of evidence, including paleontology, shall be considered. Each formation shall contain between its upper and lower limits either rocks of uniform character or rocks more or less uniformly varied in character as, for example, a rapid alternation of shale and limestone. * * * The definition of a formation *** should include a 
statement of the important facts which led to its discrimination and of the characteristics by which it may be identified in the field, whether by geologist or layman.

As uniform conditions of deposition were local as well as temporary, it is to be assumed that each formation is limited in horizontal extent. The formation should be recognized and should be called by the same name as far as it can be traced and identified by means of its lithologic character, its stratigraphic association, and its contained fossils.

The Survey has a committee on geologic names, which considers all questions of nomenclature that are raised by every paper offered for publication. The matter now stands as follows:

1. According to the ruling of the Survey all formations shall receive geographic names.

2. The necessity for this rule is demonstrated in the present review, because no two formations are found which are altogether coincident in time, although they may partly or very largely overlap in time.

3. Both formation and faunistic names are more or less subject to the law of priority of definition; but it is considered desirable by the committee on geologic names that certain names which are appropriate and have become well established in the literature should be retained, although their meanings may be preoccupied technically by other names which have not come into such general use.

\section{CORRELATION.}

The correlation of the Tertiary mammal horizons of western North America with those of Europe has engaged the attention especially of Cope (1879, 1884), Scott (1887), Clark (1891, 1896), Dall (1896, $1897)$, and Osborn $(1897,1898,1900)$. As exact correlation appeared to be an essential for the writer's phylogenetic studies of the rhinoceroses and other groups, he published in 1897 a "Trial sheet of the typical and homotaxial horizons of Europe" as the basis of cooperation with various European geologists. Their kind criticisms and corrections were embodied in a "Second trial sheet" (1898) and in a "Third trial sheet" (1900).

In the years 1899 and 1900 the writer gave two addresses ${ }^{a}$ before the New York Academy of Sciences, entitled "Correlation between Tertiary mammal horizons of Europe and America" and "Faunal relations of Europe and America during the Tertiary period and theory of the successive invasions of an African fauna into Europe." In 1899 Dr. W. D. Matthew published "A provisional classification of the fresh-water Tertiary of the West."b In June, 1905, there began in the Comptes Rendus a series of papers by Prof. Charles Depéret,

\footnotetext{
a Osborn, II.F., Correlation between Tertiary mammal horizons of Europe and America; an introduction to the more exact investigation of Tertiary zoogeography; preliminary study, with third trial sheet: Ann. New York Acad. Sci., vol. 13, No. 1, July 21, 1900, pp. 1-64.

Osborn, II. F., Corrélation des horizons de mammifères tertiaires en Europe et en Amérique: Compt. Rend. 8e Cong. géol. intern., 1900, pp. 357-363.

$b$ Bull. Am. Mus. Nat. Hist., vol. 21, 1899, pp. 19-75.
} 
entitled "L'évolution des mammifères tertiaires, méthodes et principes, importance des migrations,"a covering with fullness and precision the same subject of the Tertiary mammal succession of Europe and the migrations between the continents of Eurasia, North America, and Africa. For reasons fully set forth in the writer's correlation paper of 1899, he has adopted the faunistic subdivisions of France as classified by Depéret.

Taking renewed advantage of Professor Depéret's research and availing himself of the able cooperation of Doctor Matthew, the writer now outlines the methods and data of Tertiary correlation of the continental mountain and plains regions, and again treats the subject of migrations and American and European parallels from the standpoint of the remarkable American succession, which is now without a gap except in the Pliocene. The Pacific coast and Atlantic coast Tertiaries are not included in this review.

Many of the ideas are developments of those first expressed in the writer's correlation addresses above referred to and in his other addresses: "Rise of the Mammalia in North America" (1893), "and "Ten years' progress in mammalian ṕaleontology" (1903).c A preliminary abstract of the present paper was published by permission of Director Walcott in March, 1907.d

\section{BIBLIOGRAPHY OF WESTERN CENOZOIC HORIZONS AND THEIR CORRELATION.}

The following bibliography contains only the most significant papers:

\section{RECENT BIBLIOGRAPHY AND FORMATION NAMES.}

Weeks, F. B. Bibliography of North American geology, paleontology, petrology: and mineralogy for the years 1892-1900, inclusive. U. S. Geol. Survey, Bulls. Nos. 188, 189, 1902.

North American geologic formation names. Bibliography, synonymy, and distribution. U. S. Geol. Survey Bull. No. 191, 1902.

Bibliography and index of North American geology, paleontology, petrology, and mineralogy for the years 1901-1905, inclusive. U. S. Geol. Survey, Bull. No. 301, 1906.

\section{GENERAL CORRELATION OF TERTIARY HORIZONS.}

Clark, W. B. Correlation papers-Eocene. The Eocene of the United States. U. S. Geol. Survey, Bull. No. 83, 1891, pp. 9-159.

Eocene of the Atlantic coast, Gulf States, Pacific coast; historical sketch of the Eocene of the interior. Table showing relative position of interior Eocene deposits. Map. Extensive bibliography.

\footnotetext{
$a$ L'évolution des mammifères tertiaires. [1] Méthodes et principes: Compt. Rend. Acad. Sci. Paris, vol. 140 (June 5, 1905), p. 1517. [2] Réponse aux observations de M. Boule: Idem, vol. 141 (July 3, 1905), p. 22. [3] Importance des migrations: Idem, vol. 141 (Nov. 6, 1905), p. 703 . [4] Importance des migrations: Idem, vol. 142 (Mar. 12, 1906), p. 618.

$b$ Proc. Am. Assoc. Adv. Sci., 1894, pp. 188-277. Am. Jour. Sci., 3d ser., vol. 46, 1893, pp. 379-392, 448-446. $c$ Compt. Rend. 6e Cong. intern. de zoologie, 1904, pp. 86-113.

d'Tertiary mammal horizons of North America: Bull. Am. Mus. Nat. Hist., vol. 23, art. 11, March 30, 1907, pp. 237-253.
} 
COPE. E. D. The relations of the horizons oi extinct Vertebrata of Europe and North America. L. S. Geol. and Geog. Survey Terr., Bull.. vol. 5. No. 1. 1879. Correlation of Mesozoic and Cenozoic horizons of Europe and North America.

The Vertebrata of the Tertiary formations of the West. Rept. L. S. Geol. Survey Terr.. vol. 3, 1883 (18s4). Section I.-The Tertiary formations of the central region of the Lnited States. Section II.-The horizontal relations of the North American Tertiaries with those of Europe.

DALl. W. H. A table of the Jorth American Tertiary horizons correlated with one another and with those of western Europe; with annotations. U. S. Geol. Survey. 18th Ann. Rept., 1896-97, pt. 2, 1898.

Marine Tertiary horizons of the Atlantic coast and of the Gulf States correlated with one another, with those of the Western States and those of western Europe.

Dathiss. W. Bord. The classification of the Tertiary period by means of the Mammalia. Quart. Jour. Geol. Soc.. 18\$0, pp. 379-405.

Tertiary and Quaternary horizons and faunæ of Great Britain, France, and Italy correlated.

Filhol. H. Observations sur le mémoire de M. Cope intitulé Pélations des horizons *** d'animaux vertébrés fossiles en Europe et en Amérique. Ann. sci. géol. vol. 17, art. う. 1855. pp. 1-18.

MARsH. O. C. Geologic horizons as determined by vertebrate fossils. Am. Jour. Sci.. Oct.. 1591. 3d ser.. vol. 42. pp. 336-338.

Comparative value of different kinds of fossils in determining geological age. Am. Jour. Sci.. Dec., 1898, 4th ser., vol. 6. pp. 483-486.

Value of a form depends upon its modifiability in accordance with changing conditions.

Osвors. H. F. Correlation between Tertiary mammal horizons of Europe and America: an introduction to the more exact investigation of Tertiary zoogeography: preliminary study. with third trial sheet. Yew York Acad. Sci.. Ann.. vol. 13. 1900. pp. 1-64.

Corrélation des horizons de mammifères tertiaires en Europe et en Amérique. Compt. Rend. \&e Cong. géol. intern.. 1900. pp. 35i-363.

The geological and faunal relations of Europe and America during the Tertiary period and the theory of the successive invasions of an African fauna. science. n. s.. vol. 2. 1900. pp. 561-5i4.

Popular presentatinn of abore-cited address.

\section{GENERAL GEOLOGY AND FALXe (YORTH AMERICA).}

DAvis. W. If. The fresh-water Tertiary formations of the Rocky Mountain region. Am. Acad. Arts and Sci., Proc.. vol. 35, 1900. pp. 346-373.

History of opinion on mode of formation; eridence against lake-bed hrpothesis and in faror of fluriatile origin.

Gilbert. G. K. The underground waters of the Arkansas Valley in eastern Colorado. L. S. Geol. Survey, 17th Ann. Rept.. pt. 2, 1896, pp. 553-601.

Rocky Mountain deposits mas be of fluriatile and not of lacustrine origin.

Johrsox. II. D. The High Plains and their utilization. U. S. Geol. Survey. 21st Ann. Rept.. pt. 4. 1901, pp. 601-741; 22d Ann. Rept., pt. 4, 1902. pp. 631-669.

Tertiary deposits of the plains, of fluriatile and flood-plain origin.

MARsH. O. C. Ancient lake basins of the Rocky Mountain region. Am. Jour. Sci., Jan.. 18i5. 3d ser.. vol. 9. pp. 49-52.

Introduction and succession of vertebrate life in America. Am. Jour. Sci., 3d ser.. vol. 9. 18i i. pp. 33i-3is.

Plate showing successire horizons named from characteristic genera. 
Matthew, W. D. A provisional classification of the fresh-water Tertiary of the West. Am. Mus. Nat. Hist., Bull., vol. 12, 1899, pp. 19-77.

Divisions of the Tertiary lake basins; fossiliferous horizons of the G reat Plains; extensive faunal lists.

Osborn, H. F. Ten years' progress in the mammalian paleontology of North America. Compt. Rend. 6e Cong. intern. de zoologie, session de Berne, 1904, pp. 86-113. Reprinted without the plates in Am. Geologist, vol. 36, 1905, pp. 199-229.

A summary. New phylogenetic problems. Review of the successive faunæ. Extensive references.

Wortman, J. L. Studies of Eocene Mammalia in the Marsh collection, Peabody Museum. Pt. II, Primates. Am. Jour. Sci., June, 1903, vol. 15, pp. $419-436$.

European and American early Tertiary faunæ and floræ, probably derived from temperate Aretic land mass.

\section{EOCENE.}

Cope, E. D. The badlands of Wind River and their fauna. Am. Naturalist, vol. 14, 1880, pp. $745-748$.

Eocene.

Darton, N. H. Geology of the Bighorn Mountains. U. S. Geol. Survey, Prof. Paper No. 51, 1906.

See especially Bridger [i. e., Wind River] formation. p. 70.

Dotglass, Earl. The discovery of Torrejon mammals in Montana. Science, n. s., vol. 15, 1902, pp. 272-273.

A Cretaceous and lower Tertiary section in south-central Montana. Am. Philos. Soc., Proc., vol. 41, 1902, pp. 207-224.

Sketch of the Jurassic and Cretaceous deposits. Probable relations of the Laramie and overlying beds. Fossil mammals of the Fort Union beds.

Earle, Charles. See Osborn, H. F., and Earle, Charles.

HaY, O. P. The fossil turtles of the Bridger basin. Am. Geologist, vol. 35, June, 1905, pp. 327-342.

Evidence showing that the Bridger basin is of flood-plain, not lacustrine origin.

Hills, R. C. Recently discovered Tertiary beds of the Huerfano basin, Denver, 1888. Additional notes on the Huerfano beds. Colorado Sci. Soc., Proc., Oct. 7, 1889.

Remarks on the classification of the Huerfano Eocene. Colorado Sci. Soc., Proc., vol. 4, 1891, pp. 7-9.

HAYDEn, F. V. Geological report of the exploration of the Yellowstone and Missouri rivers, by F. V. Hayden, assistant to Col. William F. Raynolds, U. S. Engineers, Washington, 1869.

Preliminary field report of the United States Geological Survey of Colorado and New Mexico (separate), Washington, 1869.

Bridger group, type description, p. 91.

Loomis, F. B. Origin of the Wasatch deposits. Am. Jour. Sci., May, 1907 th ser., vol. 23 , pp. $356-364$.

Analysis of the fauna, of the stratigraphy, and of the petrography disproves lake-bed hypothesis and supports flood-plain hypothesis of the origin of the deposits. Detailed section. Lambdotherium primævum sp. nov., Glyptosaurus obtusidens sp. nov.

Matthew, W. D. A revision of the Puerco fauna. Am. Mus. Nat. Hist., Bull., vol. 9, 1897, pp. 259-323.

Faunal distinctiveness of the Puerco and Torrejon. 
McMaster, J. B. Stratigraphical report upon the Bridger beds in the Washakie basin, Wyoming Territory, accompanied by profiles of three sections. In Osborn. H. F., A memoir upon Loxolophodon and Cintatherium ... E. M. Mus. Geol. Archæol. Princeton, etc., Contr., 4º, vol. 1, No. 1, 1881.

Waskakie formation.

Osborx, H. F. A memoir upon Loxolophodon and Uintatherium. E. M. Mus. Geol. Archæol. Princeton, etc., Contr., vol. 1, No. 1, 1881.

' Washakie' more recent than Bridger formation.

The Perissodactyla. Part III of Scott, II. B., and Osborn, H. F., The Mammalia of the Linta formation. Am. Philos. Soc., Trans., n. s., rol. 16, pt. 3, Aug. 20, 1889, pp. 505-530.

Fossil mammals of the Linta Basin; Expedition of 1894. Am. Mus. Nat. Hist., Bull., vol. ‘. 1895, pp. 71-105.

Geology of the Cinta Basin; the three faunal lerels (horizons A, B. C). with faunal lists. New genera and species, especially of Mesonyx, Telmatherium, Sphenocœlus, and Elotherium.

The Huerfano lake hasin, southern Colorado, and its Wind River and Bridger fauna. Am. Mus. Xat. Hist., Bull., vol. 9, 1897, pp. 247-258.

Stratigraphy; analysis of Hill's report; faunal division into a lower horizon of Wind River age and an upper horizon of Bridger age.

and Earle, Charles. Fossil mammals of the Puerco beds; collection of 1892. Am. Mus. Nat. Hist., Bull., vol. 7,1895 , pp. 1-70.

Notes on the geology (Wortman). Analysis and description of the fauna.

and Wortu.x, J. L. Fossil mammals of the Wahsatch and Wind River beds; collection of 1891. Am. Mus. Nat. Hist., Bull., vol. 4, 1892, pp. 81-147

Geology of the Bighorn Basin (Wortman), p. 135: analysis and description of the fauna (Osborn).

Scotт, W. B. The upper Eocene lacustrine formations of the West. Am. Assoc. Adr. Sci.. Proc., 1887 (1888), p. 21\%. Abstract.

The upper Eocene lacustrine formations of the United States. Am. Assoc. Adv. Sci., Proc., vol. 36, 185i, pp. 21i-218.

The geological and faunal relations of the Linta formation. Pt. I of Scott, IV. B., and Osborn, H. F.. The Mammalia of the Uinta formation. Am. Philos. Soc., Trans., n. s., vol. 16, pt. 2, Aug. 20, 1859, pp. 462-470.

The selenodont artiodactyls of the Uinta Eocene. Wagner Free Inst. Sci., Trans., vol. 6, 1899. pp. i-xiii, 1j-122, pls. 1-4.

Angular unconformity between horizons B and C White River bedshomotaxial with Ronzob ol France (vide Hatcher). Cinta compared with Parıs gypsum (Lutétien), 1 e. lower Oligocene [upper Eocene].

Sixclair, W. J. Volcanic ash in the Bridger beds of Wyoming. Am. Mus. Nat. Hist., Bull. 22, 1906, pp. 273-280.

Cieneral features of the geologs. Lithologic and stratigraphic classification of the Bridger group.

VeAtch, A. C. Geography and geology of a portion of southwestern Wyoming, with special reference to coal and oil. L. S. Geol. Survey, Prof. Paper No. 56,190 \%.

Deposits of the period between the known Cretaceous and the known Eocene: Evanston formation (Eocene?), p. 86; Wasatch group, pp. 87-96; Green River formation, p. 97; Bridger formation, p. 99. 
Wortman, J. L. Geological and geographical sketch of the Bighorn Basin. In Osborn, H. F., and Wortman, J. L., Fossil mammals of the Wahsatch and Wind River beds. Am. Mus. Nat. Hist., Bull., vol. 4, 1892, pp. 135-144.

Wind River beds distinct from and successive to the Wasatch of Bighorn Basin.

and Osborn, H. F. See Osborn, H. F., and Wortman, J. L.

\section{OLIGOCENE, MIOCENE, PLIOCENE.}

Cockerell, T. D. A. The fossil fauna and flora of the Florissant (Colorado) shales. Univ. Colorado, Studies, vol. 3, 1906, Boulder, Colo., pp. 157-176.

Birds, fishes, insects, mollusks, plants.

Cope, E. D. Observations on the faunæ of the Miocene Tertiaries of Oregon. U.S. Geol. and Geog. Survey Terr., Bull., vol. 5, 1879-80, pp. 55-69. John Day (Oligocene).

Second contribution to a knowledge of the Miocene fauna of Oregon. Am. Philos. Soc., Proc., vol. 18, 1879, pp. 370-376.

John Day (Oligocene).

The White River beds of Swift Current River, Northwest Territory. Am. Naturalist, vol. 19, 1885, p. 163.

Oligocene, White River.

The Vertebrata of the Swift Current Creek region of the Cypress Hills. Geol. and Nat. Hist. Survey Canada, Ann. Rept., vol. 1, 1885 (1886), appendix to Article C, pp. 79-85.

Oligocene.

A preliminary report on the vertebrate paleontology of the Llano Estacado. Geol. Survey Texas, 4th Ann. Rept., 1892 (1893), pp. 1-136.

Description of the vertebrate fauna of the Loup Fork beds of the Llano Estacado, Texas.

Cummins, W. F.. Notes on the geology of northwest Texas. Geol. Survey Texas, 3d Ann. Rept., 1891 (1892), pp. 129-200; 4th Ann. Rept., 1892 (1893), pp. 179-238.

Geology of the Llano Estacado.

Dall, W. H. Age of the Peace Creek bone beds of Florida. Acad. Nat. Sci. Philadelphia, Proc., 1891, p. 121.

Included in Pliocene.

Geological results of the study of the Tertiary fauna of Florida, 1886-1903.

Wagner Free Inst. of Science, Philadelphia, Trans., vol. 3, pt. 6, 1903, pp. 1541-1620.

Oligocene and later formations. Tertiary Mollusca.

and Harris, G. D. Correlation papers. The Neocene of North America. U. S. Geol. Survey, Bull. No. 84, 1892.

See especially Chapter VI, on the supposed Neocene of the interior region, considered by States, pp. 280-317. Table showing the vertical range of the Neocene of the interior. Map, p. 178. List of names applied to Cenozoic beds and formations of the United States, p. 320.

Darton, N. H. Preliminary report on the geology and underground-water resources of the central Great Plains. U. S. Geol. Survey, Prof. Paper No. 32, Washington, 1905.

See especially Chadron (Titanotherium), Brule (Oreodon), Arikaree, Ogalalla formations. 
Darton, N. H. Age of the Monument Creek formation. Am. Jour. Sci., Sept., 1905, 4th ser., vol. 20 , pp. 178-180.

Titanotherium remains. Oligocene.

Geology and underground waters of the Arkansas Valley in eastern Colorado, U. S. Geol. Survey, Prof. Paper No. 52, 1906.

Monument Creek formation, containing Titanotherium of White River age, p. 34; Nussbaum formation, of late Tertiary age, p. 34 .

Douglass, Earl. The Neocene lake beds of western Montana, and descriptions of some new vertebrates from the Loup Fork. Univ. Montana, thesis, June, 1899.

Geology, faunæ, and correlation of White River, Deep River, ánd Madison Valley; Loup Fork horizons in Montana; systematic description of certain fossil camels, etc.

Fossil Mammalia of the White River beds of Montana. Am. Philos. Soc., Trans., n. s., vol. 20, 1901, pp. 1-42, pl. ix.

Pipestone beds, Toston beds, Blacktail Deer Creek beds. Geology and faunæ; new genera and species of mammals.

New vertebrates from the Montana Tertiary. Carnegie Mus. (Pittsburg, Pa.), Ann., vol. 2, No. 2, 1903, pp. 145-200.

Sage Creek beds (?Eocene), White River deposits, Fort Logan beds (upper Oligocene), Deep River and Flint Creek beds. New mammals described.

The Tertiary of Montana. Carnegie Mus. (Pittsburg, Pa.), Mem., vol. 2, 1905, pp. 203-224.

Chiefly a description of Ictops, Xenotherium, and other lower. W' hite River mammals.

Gidlex; J. W. The fresh-water Tertiary of northwestern Texas, American Museum Expedition of 1899-1901. Am. Mus. Nat. Hist., Bull., vol. 19, 1903, pp. 617-635.

Geologic notes and sections; new mammals described. Rock Creek beds $=$ Sheridan (Equus) beds (Pleistocene); Blanco beds (Pliocene); sections (1) at Mount Blanco of (?) Goodnight (Paloduro) Miocene, (2) showing Panhandle (lower or middle Miocene) beds, and (3) of Clarendon (Loup Fork) and Panhandle. Maps, faunæ.

- See Matthew, W. D., and Gidley, J. W.

Gilbert, G. K. Lake Bonneville. U. S. Geol. Survey, Mon., vol. 1, 1890.

The age of the Equus fauna, p. 393. Faunally later than upper Pliocene of Arno Valley, and earlier than mid-Pleistocene, but surviving in Lake Bonneville region into middle or upper Pleistocene.

Harris, G. D. See Dall, W. H., and Harris, G. D.

Hatcher, J. B. Discovery of Diceratherium, the two-horned rhinoceros, in the White River beds of South Dakota. Am. Geologist, vol. 13, 1894, pp. 360-361.

Top of White River correlated with John Day formation.

On a small collection of vertebrate fossils from the Loup Fork beds of northwestern Nebraska; with note on the geology of the region. Am. Naturalist, vol. 28, 1894, pp. 236-248.

Elurodon, A phelops, Teleoceras, Loup Fork and Equus beds.

The Titanotherium beds. Am. Naturalist, Mar. 1, 1893, pp. 204-221.

Geographic distribution, description, stratigraphy; faunistic divisıon into lower, middle, and upper beds.

Origin of the Oligocene and Miocene deposits of the Great Plains. Am. Philos. Soc., Proc., vol. 41, 1902, pp. 113-131.

Gering, Arikaree, Ogalalla, Monroe Creek, Harrison, and Nebraska of Scott; classification of the Oligocene and Hocene; "lake-bed" hypothesis of origin disproved in favor of fluviatile, flood-plain, and eolian hypothesis. 
Haworth, E. Physical properties of the Tertiary [of Kansas]. ['niv. Geol. Survey Kansas, vol. 2, 1896, pp. 247-281.

Rejects "lake-basin" hypothesis in favor of hypothesis of fluviatile origin of Tertiary of Kansas.

HAy, R. Northwest Kansas; its topography, geology, climate, and resources. Kansas State Bd. Agr., 6th Bien. Rept., 1889.

See especially discussions of the Tertiary geology of Kansas.

Inviva, J. D. The stratigraphical relations of the Browns Park beds of Utah. New York Acad. Sci., Trans., vol. 15, Sept., 1896, p. 252.

The beds in Browns Park Valley assigned to the Pliocene.

Knowlton, F. H. Fossil flora of the John Day basin, Oregon. U. S. Geol. Survey, Bull. No. 204, 1902.

Geology, pp. 14-20, 102-108. Mascall formation referred to upper Miocene.

Leidy, J., and Lucas, F. A. Fossil vertebrates from the Alachua clays of Florida. Wagner Free Inst. Sci., Trans., vol. 4, 1896, pp. vii-xiv, 15-61.

Mastodon fioridanus, A phelops fossiger, A. malacorhinus, Procamelus major, $P$. medius, P. minimus, Itippotherium plicatile, II. gratium, Equus major.

Looms, F. B. Two new river reptiles from the titanothere beds. Am. Jour. Sci., Dec., 1904, 4th ser., vol. 18, pp. 427-432.

Flood-plain origin of Titanotherium beds.

Lucas, F. A. See Leidy, J., and Lucas, F. A.

Matthew, W. D. Is the White River Tertiary an eolian formation? Am. Naturalist, vol. 33,1899 , pp. 403-408.

Summary of the paleontologic evidence against the lake-basin hypothesis.

Fossil mammals of the Tertiary of northeastern Colorado. Am. Mus. Nat. Hist., Mem. 1, pt. 7, Nov., 1901.

Stratigraphy of White River formation (Horsetail Creek, Cedar Creek, and Martin Canyon beds), of Loup Fork formation (Pawnee Creek beds). Evidence as to mode of deposition (chiefly eolian); analysis of faunæ; correlation of horizons; systematic descriptions.

The fauna of the Titanotherium beds at Pipestone Springs, Mont. Am. Mus. Nat. Hist., Bull., vol. 19, 1903, pp. 197-226.

Notes on stratigraphy; systematic descriptions of new fossil mammals.

A lower Miocene fauna from South Dakota. Am. Mus. Nat. Hist., Bull., vol. $23,1907,169-219$.

Lower and upper Rosebud formations and faunæ; comparison with American Oligocene and Miocene faunæ New Carnivora, Rodentia. Artiodactyla.

and Gridey, J. W. New or little-known mammals from the Miocene of South Dakota. Am. Mus. Nat. Hist., Bull., vol. 20, 1904, pp. 241-271.

Upper Miocene Loup Fork beds, geology and Launal list; lower Miocene Rosebud beds (new name) New Carnivora and Rodentia

Merriam, J. C. A contribution to the geology of the John Day basin. Univ. California, Bull. Dept. Geology, vol. 2, 1901, p. 269.

Geology, faunæ, and floræ of the Cretaceous (Chico and Knoxville), Eocene (Clarno), Oligocene (John Day series) Columbia lava, Miocene (Mascall), Pliocene (Rattlesnake), Quaternary.

Carnivora from the Tertiary formations of the John Day region. Univ. California, Bull. Dept. Geology, vol. 5, 1906, pp. 1-64, pls. 1-6.

Brief notes on the Tertiary formations of the John Day region. Description of the Canidæ and Felidæ John Day carnivores more advanced in structure than White River carnivores. less advanced than Loup Fork carnivores. 
[Osbors. H. F.] Professor Fraas on the aqueous vs. eolian deposition of the IThite River Oligocene of South Dakota. Science, n. s.. vol. 14. 1901. pp. $210-212$.

Titanotherium beds formed hy river and flood-plain deposits exposed during iry season. Yiddle Orcodon beds deposited br a shallow lake with dissolved materials of rarying concentration / cf. banded layers. Cpper Oreodon beds formed by eolian loess.

Osвors. H. F. See scott. W. B.. and Osbors. H. F.

and Wortmas. J. L. Perissodactyls of the lower Miocene White River berls.

Am. Mus. Lat. Hist. Bull., vol. 7. 1993. pp. 343-375.

i)tignere.

Fossil mammals of the lower Miocene IThite Piver berls: collection of 1592. Am. Mus. Nat. Hist.. Bull. rol. 5. 1694. pp. 199-229.

succession of species in the White Rirer "Miocene" [= Oligocene]

Petersox. 0. A. Osteolugy of Ondactyliss. I new genus of camels from the Loup Fork of Jebraska. with descriptions of two new species. Carnegie Mus., Ann.. vol. 2. No. 3. Feb.. 1904.

reologic notes and section. pp $5-3-4.5$.

Description of new rodents and discussion of the origin of Dxmonelir. ("arnegie Mus.. Mem.. vol. 2. 1905. pp. 13?-191.

New rodents from the $D x m o n e l i x$ beds. Harrison formation Miocene. I'xmonelix explained as the cast of a spiral burrow made by rodents (Stencofiber.

The Agate spring fnasil quarry. Carnegie Mus.. Ann.. wrol. 3. No. 4. 190t. pp. $45-794$.

Iforizon regarded as equiralent to the top of the lower IIarison formation.

The Miocene berls of western Nebraska and eastern Wyoming and their vertebrate faunze.

Carnegie Mus.. Inn., vol. 4, No. 1. 1\%t, pp. 21--2.2.

Vew suilline remains from the Miocene of Jebraska. Carnegie Mu-.. Ann.. vol. 2. Jo. s. 1906 . pp. 30.5-320.

$\therefore$ sp. in Thinohym. Comparison with John Day species shows greater specialization. p. 320.

scotт. W. B. The mammals of the Deep River berls. Am. Naturalist. vol. 2T. 1693. pp. $6.53-652$.

Preiminary description

The later Tertiary lacustrine iormations of the West. Genl. Sor. America. Bull.. vol. 5. 1593 (1594\% pp. $594-595$.

Velicasica inrmation. Cosorys heds. Type reference.

The Mammalia of the Deep River beds. Am. Philos. Ane.. Trans.. n. s.. vol. 15. 159.5. No. 2. pp. 5.5-15.5.

Geolngy. pp. 3j-13. European homota xis with Sanson and Simorre midfle Miocene .

and Osbors. H. F. Preliminary account of the fossil mammals from the Whit Fiver formation crntained in the Museum of Comparative Zoology. Mus. Comp. Zorl. Hartard Coll. Bull.. val. 13. 185-. pp. 152-171.

Sctuder, S. H. The Tertiary insects of North America. L. S. Gerl. Survey Terr., Pepi.. vol. 13. 1890.

Map oi the Tertiary lake basin at Florissant. Colo. Geology of the deposits yielding Tertiary insects in -tmerica. Florissant $=-1 m$ yzon beds (Oligocene? . Volcanic origin of the deposits. 
Sinclair, IT. J. New or imperfectly known rodents and ungulates from the John Day series. Univ. California, Bull. Dept. Geology, vol. 4, 1905, pp. $125-143$.

Sternberg, C. H. The Loup Fork Miocene of western Kansas. Kansas Acad. Sci., Trans., vol. 20, pt. 1, 1904, pp. 71-74.

Mode of deposition discussed.

Wortman, J. L. On the divisions of the White River or lower Miocene of Dakota.

Im. Mus. Nat. Hist., Bull., vol. 5, 1893, pp. 95-106.

Description and stratigraphic table of the Titanotherium and Oreodon beds; Protoceras beds; faunal distribution and succession of types.

See Osborn, H. F., and Wortman, J. L.

\section{PLEISTOCENE.}

Beede, J. IT. See Haworth, E., and Beede, J. W.

Cope, E. D. Description of some vertebrate remains from the Port Kennedy bone deposit. Acad. Nat. Sci. Philadelphia, Proc., vol. 11, 1876, pt. 2, pp. 193-267.

Pleistocene.

The Silver Lake of Oregon and its region. Am. Naturalist, vol. 23, 1889, pp. 970-982.

Pleistocene. Fauna and geology.

and Wortmax, J. L. An account of the mammalian fauna of the post-Pliocene deposits of Indiana. State Geol. Indiana, 14th Rept., pt. 2, 1884.

Pleistocene.

Furlong, E. L. An account of the preliminary excavations in a recently explored Quaternary cave in Shasta County, Cal. Science, n. s., vol. 20, July 8, 1904, pp. 53-54.

Faunal lists.

The exploration of Samwel Cave. Am. Jour. Sci., September, 1906, 4th ser., vol. 22 , pp. $235-247$.

Pleistocene.

Reconnoissance of a recently discovered Quaternary cave deposit near Auburn, Cal. Science, n. s., vol. 25, 1907, pp. 392-394.

Faunal lists.

Gilbert, G. K. See Hall, J., and Gilbert, G. K.

Hall, J., and Gilbert, G. K. Notes and observations on the Cohoes mastodon. Notes of investigations at Cohoes with reference to the circumstances of the deposition of the skeleton of Mastodon. New York State Cab. Nat. Hist, 21st Ann. Rept., 1871.

Characteristic sections of Pleistocene deposits.

Hatcher, J. B. Discovery of a musk-ox skull (Ovibos cavifrons Leidy) in West Virginia, near Steubenville, Ohio [by Sam Huston]. 'Science, vol. 16, 1902, p. 707.

Faunal changes in the region during glacial period.

Haworth, E., and Beede, J. W. The McPherson Equus beds [of Kansas]. Univ. Geol. Survey Kansas, vol. 2, 1896 (1897), pp. 287-296.

Matthew, W. D. List of the Pleistocene fauna from Hay Springs, Nebr. Am. Mus.

Nat. Hist., Bull., vol. 16, 1902, pp. 317-322.

Hay Springs (Nebraska), Silver Lake (Oregon), Oregon Desert, Washtuckna Lake (Washington).

56092-Bull. $361-09-2$ 
Mercer, H. C. The bone cave at Port Kennedy, Pa. Acad. Nat. Sci. Philadelphia, Jour., vol. 11, 1899, pt. 2.

Referred to the Pleistocene, but without comparison with other cave formations and faunæ.

Merriam, J. C. Recent cave exploration in California. Am. Anthropologist, n. s., vol. 8,1906, pp. 221-228.

Mercer's, Potter Creek, Samwel, and Stone Man caves, probably of Quaternary age.

Scudder, S. H. The effect of glaciation and of the glacial period on the present fauna of North America. Am. Jour. Sci., Sept., 1904, 3d ser., vol. 48, pp. 179-187.

Shufeldt, R. W. A study of the fossil avifauna of the Equus beds of the Oregon desert. Acad. Nat. Sci. Philadelphia, Jour., vol. 9, 1892, p. 389.

Sinclair, W. J. A preliminary account of the exploration of the Potter Creek cave, Shasta County, Cal. Science, n. s., vol. 17, 1903, pp. 708-712.

The exploration of the Potter Creek cave. Univ. California, American Archæology and Ethnology, vol. 2, 1904, pp. 1-27, pls. 1-14.

Late Quaternary age.

New Mammalia from the Quaternary caves of California. Univ. California, Bull. Dept. Geology, vol. 4, 1905, pp. 145-161.

Williston, S. W. An arrowhead found with bones of Bison occidentalis in western Kansas. Am. Geologist, vol. 30, 1902, pp. 313-315.

Arrowhead in undoubted association with an extinct species, Bison occidentalis, in beds referred by Williston to the Equus beds.

- The Pleistocene [of Kansas]. Univ. Geol. Survey Kansas, vol. 2, 1896, pp. 299-308.

Kansas Pleistocene deposits and faunæe.

Wortman, J. L. See Cope, E. D., and Wortman, J. L. 


\section{CHAPTER I。}

\section{GENERAL GEOLOGIC AND CLIMATIC HISTORY OF THE TERTIARY.}

Although, as observed in the introduction (p. 7), we still lack exact knowledge, certain broad generalizations are beginning to emerge from the facts collected chiefly by American paleontologists since the pioneer studies of Hayden and Leidy in the middle of the last century.

Among the earlier contributors to our geologic and stratigraphic knowledge are Hayden, Leidy, Marsh, Cope, King, Scott, and Osborn. Among the more recent contributors are Matthew, Hatcher, Wortman, Darton, Merriam, Peterson, Douglass, Gidley, Granger, and Sinclair. ${ }^{a}$

The most central fact established is that there were during the Tertiary period two grand natural divisions of geologic deposition and of animal and plant habitat, similar to the two natural divisions which exist to-day, namely, (1) the Mountain Region and (2) the Plains Region.

\section{THE MOUNTAIN REGION.}

The mountain and high-plateau region, as a whole, stretched north through British Columbia to its broad Asiatic land connection, which was apparently interrupted and renewed more than once during the Tertiary period. On the south it terminated, according to Suess, in the mountains which form the northern boundary of the southern Mexican State of Oaxaca. We have a few glimpses of the life of limited areas of this vast region in Tertiary time.

The Eocene Tertiaries of the Mountain Region, lying in and west of the Rockies, in which the life is best known, were partly formed by the post-Cretaceous or post-Laramie uplift, accompanied by great volcanic activity, lava flows, and eruptions of volcanic dust, and by the formation of a series of lake, river, and flood-plain basins, filled with volcanic and erosion sediments.

\footnotetext{
$a$ Six of these observers either have been continuously or were for a time connected with the expeditions sent out by the present writer from the department of vertebrate paleontology of the Amer can Museum of Natural History, with instructions to combine very precise geologic and paleontologic observations. Of the others, Hatcher's pioneer work for the United States Geological Survey and for the Carnegie Museum, Merriam's and Sinclair's work in the John Day region (University of California studies), and Douglass's observations in Montana have been most important. Darton's report on the central Great Plains (1905) is the latest and most comprehensive contribution.
} 
The mammalian life of this region from New Mexico on the south to Montana on the north is fully known from the beginning to the close of the Eocene epoch. while it is imperfectly known during the Miocene and Pliocene epochs. It shows four phases in its relations to Europe.

1. Throughout the lower Eocene epoch it is closely similar to the far-distant life of western Europe. (See first and second faunal phases, pp. 33, 35-36.)

2. There follows a middle and upper Eocene interral of faunal separation from Europe. (See third faunal phase, pp. 4.2-43.)

3. Again there is a faunal reunion, near the beginning of the Oligocene epoch: then a dirergence, less marked than before; then a reunion in the middle Miocene, and another in the Pleistocene. But from the Oligocene onward western America, northern Asia, and Europe, or Eurasia, form a single great zoologic prorince until the late Pleistocene. (See fourth, fifth. and sixth faunal phases, pp. $57-60,76$, s.)

t. Finally, the present epoch is one of faunal dirergence or separation. (See serenth faunal phase, p. s4.)

\section{THE PLAINS REGION.}

The Tertiaries of the Plains Region lie east of the Rockies from Montana southward.

During the entire Eocene epoch the country stretching to the Mississippi and eastward to the Appalachians and Atlantic coast is, with a few exceptions, ${ }^{a}$ a terra incognita so far as its terrestrial mammalian life is concerned. Glimpses only of its marine or seashore mammalian life are afforded in the Zeuglodon zone ${ }^{b}$ of Alabama and Floridia and in other littoral marine deposits. While this rast easterm region contains no known Eocene mammal-bearing deposits, it was undoubtedly the scene of a rery actire continental ${ }^{c}$ mammalian life from the time of the emergence of the central area toward the close of the Cretaceous, or during and after Laramie time. Yet our knowledge of the life of eastern North America during the entire Eocene is only what we gain by inference from our knowledge of the life of the Mountain Region from Montana on the north $\left(47^{\circ}\right)$ to New Mexico on the south ( $36^{\circ}$ latitude), a relatively circumscribed area.

Our earliest knowledge of the mammalian life of the Great Plains is that suddenly afforded on its extreme western fringe or border in lower Oligocene time, and it is indeed a revelation. Again, with the

\footnotetext{
a For example. Marsh has reported from the supposed oligocene of New ferser two species of mammals. Elotherusm and Protapirus I Tapirarssi calidus.

$b$ Z euglodon is an aberrant whale-like form which probably originated in the Eocene of North Africa.

c $A$ s pointed ont by Suess, North America has been a continent since the clnse of the Cretaceous. and its great land surfaces are older. more permanent. and more extensive than those of Europe. The land suriaces of Africa. howerer. are far older than either.
} 
exception of important upper Miocene ("Peace Creek" and "Archer" formations) and possibly mid-Pliocene deposits in Florida, the country east of the Great Plains remains unknown until the lower Pleistocene.

These facts, which are often overlooked by paleontologists, have a very important bearing on theories as to the source or origin of the new forms of mammals which suddenly appear from time to time.

\section{RESEMBLANCES AND CONTRASTS BETWEEN MOUNTAIN AND PLAINS REGIONS.}

Resemblances.-Opening with a moderately warm and humid but far from tropical climate, with mild winters, the common physiographic and climatic history of both the Mountain and western Plains regions was that of progressive elevation, slowly progressing aridity, gradual soil denudation and deforestation, progressively sharper definition of the winter and summer seasons, concluding with destruction of most of the larger forms of life during the lower Pleistocene glacial epoch.

Contrasts.- The geologic history of the two regions presents some strong contrasts.

First, with some exceptions, the Tertiary deposits of the Mountain Region are in clearly defined basins drained by the same great river systems which drain them to-day, while those of the Plains Region are widely scattered over broad areas, with frequent changes in the river courses, the present river courses being comparatively modern.

Second, it follows that in the Mountain Region, from the basal Eocene to the summit of the upper Oligocene or John Day formation, there was little or no working over of the older Tertiary rocks into newer deposits, but there exist a number of continuous local depositions. Erosion of these depositions has been retarded fortunately in the John Day basin of Oregon by heavy cappings of lava, in the Bridger basin by a dense Pleistocene (?) conglomerate, and in the Washakie basin by a fine conglomerate. Broad expanses of these historic strata have thus been preserved in their original purity and continuity for the geologist and paleontologist.

Third, by contrast, in the Plains Region the original very extensive Oligocene strata were in part worked over to form Miocene strata, and these in turn were in part eroded to form Pliocene strata; again, all three contributed to the Pleistocene strata; and finally all four are now contributing to the alluvium of the Great Plains. Thus in the Plains Region we find Miocene river deposits laid in old Oligocene channels, and Pliocene deposits embedded in Miocene channels, as well illustrated in Gidley's sections ${ }^{a}$ in the Llano Estacado of Texas

a Gidley, J. W., The fresh-water Tertiary of northwestern Texas. American Museum expeditions of 1899-1901: Bull. Am. Mus. Nat. Hist., vol. 19, 1903, pp. 617-635. 
(fig. 15, p. 82). 'This succession of depositions and erosions has rendered the Tertiary geologic history of the Great Plains very complicated, and has retarded our geologic and paleontologic solutions.

Fourth, owing to the proximity of the volcanic zones, volcanic ash and other fine eruptive materials contributed very largely and in some basins almost exclusively to the Eocene and Oligocene deposits in the Mountain Region, while in the Plains Region, which was more distant from the active craters, volcanic-ash deposits were occasional, and conglomerates, sandstones, and clays make up the main mass of the deposits. In some Plains deposits, however, volcanic ash is a large component.

Fifth, the mammalian life of the Mountain Region was largely that of plateaus, uplands, and elevated basins, of streams and lake borders, of hillsides, and more or less of the forests. The mammalian life of the Plains Region was that of savannas and pampas, of broader plains and rivers, with more restricted forests. There was, however, no sharp life demarcation, because then, as now, some of the Plains types penetrated the Mountains and some of the Mountain types penetrated the Plains.

General homotaxis of some of the Mountain and Plains formations.

\begin{tabular}{|c|c|c|c|}
\hline & $\begin{array}{l}\text { MOUNTAIN BASIN DEPOSITS. } \\
\text { Geologic.-Partly of erosion } \\
\text { materials; largely of vol- } \\
\text { canic materials, partly } \\
\text { eolian, partly deposited } \\
\text { in water. } \\
\text { Faunistic.-Extinct mam- } \\
\text { mals, chiefly inhabiting a } \\
\text { mountainous, hilly, for- } \\
\text { ested, lake- and river- } \\
\text { bord e r, w e ll-watered } \\
\text { country. }\end{array}$ & $\begin{array}{l}\text { GREAT PLAINS DEPOSITS. } \\
\text { Geologic.-Largely of wa- } \\
\text { ter-erosion and wind-ero- } \\
\text { sion materials; partly of } \\
\text { volcanic materials. } \\
\text { Faunistic.-Extinct mam- } \\
\text { mals, chiefly of an open- } \\
\text { plains country, traversed } \\
\text { by broad, slow-moving } \\
\text { rivers, savanna, partly } \\
\text { forested, with shallow } \\
\text { lakes and decreasing rain } \\
\text { supply. }\end{array}$ & \\
\hline $\begin{array}{l}\text { Middle Pliocene.... } \\
\text { Lower Pliocene or } \\
\text { upper Miocene. } \\
\text { Upper Miocene..... } \\
\text { Middle Miocene.... } \\
\text { Lower Miocene and } \\
\text { upper Oligocene. } \\
\text { Upper Oligocene... } \\
\text { Lower Oligocene... }\end{array}$ & $\begin{array}{l}\text { Rattlesnake, Oreg......... } \\
\text { Deep River, Mont.: Mascall, } \\
\text { Oreg. } \\
\text { \{ Fort Logan," Mont....... } \\
\text { John Day (upper part), } \\
\text { Oreg. } \\
\text { John Day (midule and } \\
\text { lower parts), Oreg. } \\
\text { Deposits on Pipestone } \\
\text { Creek, Mont. }\end{array}$ & $\begin{array}{l}\text { Blanco, Tex.... } \\
\text { Ogalalla, in part ("Repub- } \\
\text { lican River"), Nebr. } \\
\text { Ogalalla ("Nebraska"), } \\
\text { Nebr. } \\
\text { "Pawnee Creek," Colo..... } \\
\text { Arikaree (Gering Rose- } \\
\text { bud), Nebr. } \\
\text { White River, S. Dak. (upper } \\
\text { part). } \\
\text { White River (lower part), } \\
\text { of the western plains, of } \\
\text { South Dakota, Nebraska, } \\
\text { etc. }\end{array}$ & $\begin{array}{l}\text { Second deposition pe- } \\
\text { riod of very wide- } \\
\text { s p read fluviatile, } \\
\text { flood-plain, and eoli- } \\
\text { an deposits, chiefly } \\
\text { erosion and volcanic } \\
\text { materials, on the } \\
\text { Great Plains of Da- } \\
\text { kota, Nebra sk a } \\
\text { Colorado, and west- } \\
\text { ern Kansas. Limit- } \\
\text { ed and scattered } \\
\text { depos it s in the } \\
\text { Rocky Mountain } \\
\text { region. } \\
\text { First deposition (or } \\
\text { Eocene) period of } \\
\text { lacustrine, river, and } \\
\text { flood-plain deposits, } \\
\text { largely of volcanic } \\
\text { materials in the } \\
\text { Rocky Mountain ba- } \\
\text { sin, chiefly in the } \\
\text { ancient drainage ba- } \\
\text { sin of Colorado Riv- } \\
\text { er. Plains deposits } \\
\text { of this period eroded } \\
\text { away, buried, or un- } \\
\text { known. }\end{array}$ \\
\hline
\end{tabular}




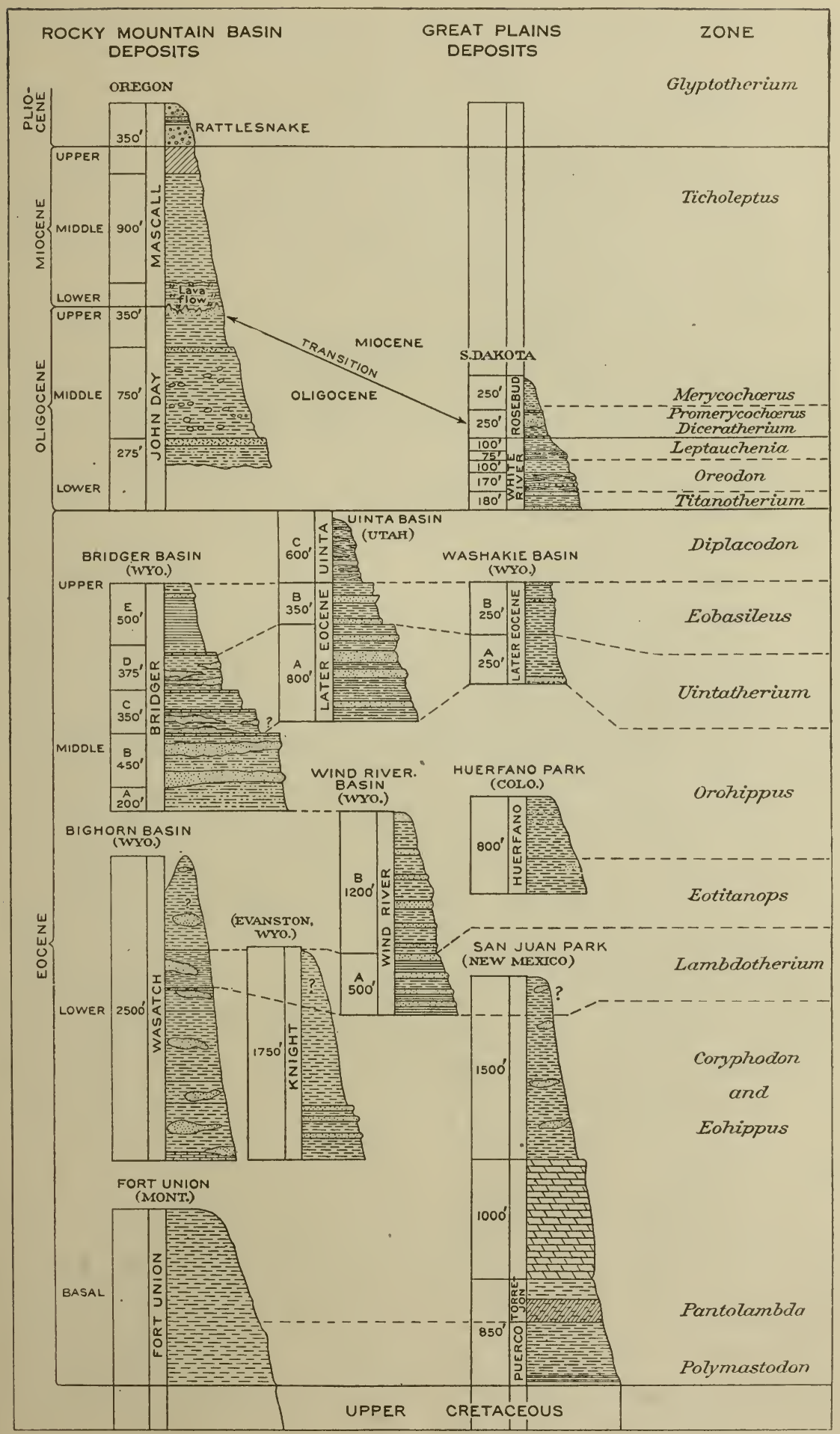

FIG. 1.-Composite section of the Tertiary deposits of the West. The thickness of these deposits is represented on the same scale throughout. The correlations indicated by dotted lines a re preliminary. 


\section{GEOLOGIC HISTORY OF MOUNTAIN BASIN DEPOSITS OF THE EOCENE AND OLIGOCENE.}

The combination by faunistic correlation of all the Eocene sections, as represented in fig. 1, gives a total thickness of 7,200 feet.

The deposits are distinguished by the following chief characters:

1. The axes of the mountain ranges were the same as at present. The mountain ranges, in relation to the surrounding country, were probably higher than at present, because we must allow for two to three million years of erosion.

2. The Eocene drainage systems were broadly the same as the modern, namely, the systems of Colorado Rirer, Arkansas River, the Bighorn branch of Missouri River, and Columbia River. In details, however, the drainage systems have certainly been modified by uplift and erosion.

3. The deposits all lie in the same great mountain basins or mountain ralleys in which they were originally deposited. (See Pl. I.)

4. Except close to the mountain foothills (e. g., Wasatch of the Bighorn Basin) there has been comparatively little Eocene or postEocene disturbance, because these deposits are still horizontal or at gentle angles with their original horizontal position.

5. The surrounding mountain ranges were interspersed with active rolcanic peaks; the upper Colorado River basin especially was surrounded by a circle of rolcanoes which poured out their lara and widely distributed their ashes.

6. From preliminary lithologic examinations the Eocene deposits have been found to consist largely, sometimes exclusirely, of rolcanic-ash materials. ${ }^{a}$ The subject has an interesting history: In 1SS5-S6 Merrill and Peale determined the rolcanic-ash origin of the "Bozeman lake beds" in Gallatin County, Mont. Peale's conclusions were interesting. ${ }^{b}$ These obserrations are in line with King's ${ }^{c}$ (1S76) previous recognition of rolcanic-ash strata in the typical Wasatch of Eranston, Wyo., immediately underlying the true Coryphodon zone of Marsh, with Wortman's note as to the rolcanic-ash nature of the Huerfano basin Pliocene, and with a number of obser-

\footnotetext{
$a$ It is interesting to note the similar rolcanic-ash character of the Santa Cruz, the chief Miocene formation of Patagonia.

$b$ Peale, A. C., Science, vol. 8 , Aug. 20, 1886, p. 163 . The article concludes as follows:

"Will we not, therefore, have to cut down very materially the great leng th of time generally believed to have elapsed in this region from the beginning of this lacustrine period to the present time, when we find that a great portion of the sediment that once filled the lakes is due, not to the products of erosion, as has hitherto been supposed, but to repeated showers of volcanic dust? Again, do not these volcanic materials, which must have fallen in showers over a large extent of country-accumulating in some cases in beds 40 to 90 feet thick-account for the perfect preservation of the vertebrate remains which characterize the formations in so many parts of the West; and is there not also suggested one possible cause for the extinction of some of the many groups of animals which have at present no descendants in this region, and whose only remains are the bony fragments found in these lacustrine deposits?",

cAm. Jour. Sci., 3d ser., vol. 11, 18i6, pp. 47s-450.
} 
vations (Barbour, Darton, and others) as to the volcanic-dust composition of certain Oligocene to Pliocene sands in Nebraska, Montana, and Colorado. Following Merriam's ${ }^{a}$ determination (1901) of the volcanic-ash nature of the deposits of the John Day basin, the next important step of recent years in relation to the Eocene lake basins is the recognition by Sinclair ${ }^{b}$ (1906) that the deposits of the Bridger basin, previously described as sandstones and clays, are also chiefly of volcanic nature or tuffs. The neighboring Washakie basin deposits are of ash (Sinclair, 1907). On preliminary examination the same observer finds tuffs in the Torrejon, Wasatch, Wind River, and Uinta, as well as in the Bridger; in other words, in the entire Eocene series. The lower part of the Wind River formation, however, and probably parts of other basin deposits, appear to be true sandstones and clays. Veatch ${ }^{c}$ (1906) confirms King's observation that just below the typical Coryphodon zone of Evanston are extensive "white beds" largely composed of volcanic ash, which he names the Fowkes formation.

7. The manner of deposition of volcanic ash in these various basins, whether blown about on a dry surface, in flood plains, or in either extensive or shallow lakes, has not been fully determined. In the Bridger formation the ash shows little evidence of prolonged water erosion. Merriam rejects the lacustrine theory of the origin of the John Day formation and speaks of "showers of ash, with tuff deposits on a plain occupied in part by shallow lakes."

8. Admirable studies of the John Day Oligocene, in most of its biotic and geologic aspects, have been made by Merriam, ${ }^{a}$ Sinclair, ${ }^{d}$ and Knowlton.e (See p. 67.)

9. The Bridger formation, 1,800 feet in thickness, is the only Eocene deposit which has been exactly examined $f$ from the standpoint of geology, petrography, and paleontology. Wind-blown volcanic ash, glass, and eruptive feldspar are large ingredients of this formation, which contains no erosion materials from the adjacent Uinta Mountains, such as we should expect to find. There is evidence of the direct deposition of the ash in water, with some working over of the

a Merriam, J. C., A contribution to the geology of the John Day basin: Bull. Dept. Geology, Univ. California, vol. 2, No. 9, A pril, 1901, pp. 269-314.

$b$ Sinclair, W. J., Volcanic ash in the Bridger beds of Wyoming: Bull. Am. Mus. Nat. Hist., vol. 22, 1906, pp. 273-280.

$c$ Veatch, A. C., Geography and geology of a portion of southwestern Wyoming, with special reference to coal and oil: Prof Paper U S. Geol. Survey No. 56, 1907.

$d$ Sinclair, W. J., New or imperfectly known rodents and ungulates from the John Day series: Bull. Univ. Califormia, Dept. Geology, vol 4, 1905, pp. 125-143.

$e$ Knowlton, F. H., Fossil flora of the John Day basin, Oregon: Bull. U. S. Geol. Survey No. 204, 1902, $153 \mathrm{pp}$.

$f$ The writer planned this survey in preparation for the United States Geological Survey monograph on the titanotheres, desiring to ascertain whether or not the Eocene titanotheres were horizontally distributed, i. e. in vertically successive life zones. As conducted by and reported on by Messrs. Matthew, Granger and Sinclair, partly for the United States Geological Survey, but chiefly for the American Museum expeditions, it succeeded tar beyond our most sanguine anticipations. 
coarser materials by streams into the so-called sandstones, while the finer materials, constituting the so-called clays, are actually tuffs. Proofs of temporary lacustrine conditions, or of prolonged high water on base-level, are found in the very widely extended so-called white layers containing calcite and flint; these divide the Bridger formation into five levels (A, B, C, D, E), each characterized by distinctive specific forms of mammalian and reptilian life. These levels demonstrate periodic risings of the water level in this basin.

10. As the fossil mammals which all these Eocene mountain deposits contain are carefully compared and studied, we nearly, if not quite, demonstrate another great fact, namely, that these deposits were successively formed, in one basin after another, throughout the Eocene period; in a number of cases, fortunately, there was a time overlap-in other words, before one deposition closed another began. When fully explored they will thus afford a nearly continuous history of the vertebrate life of the Mountain Region during the Eocene and Oligocene epochs.

\section{GEOLOGIC HISTORY OF THE GREAT PLAINS DEPOSITS OF THE OLIGOCENE, TO LOWER PLEISTOCENE.}

Extent.-The Oligocene to Pleistocene deposits immediately overlie the various divisions of the Cretaceous and form the surface of the plains at different points from 200 to 300 miles east of the Rocky Mountains, from British Columbia on the north to the Mexican plateau on the south, with a combined maximum thickness of about 2,000 feet. Their central area is best shown in Darton's preliminary geologic map of the central Great Plains. ${ }^{a}$

History of opinion as to mode of deposition. ${ }^{b}$ - The lacustrine-origin theory as to the Great Plains deposits was entertained by Owen, King, Hayden, Leidy, Cope, Marsh, Scott, and Darton; it reached its climax in King's proposal to give names to each of the great successive lakes, beginning with those in the Mountain Region. This theory of lake basins of very large extent on the Great Plains has been abandoned in the light of more exact paleontologic and geologic study.

Among the geologists, Johnson, ${ }^{c}$ Gilbert, ${ }^{d}$ Haworth, and especially Davis, who reviewed the whole subject in a broad and critical way, have advocated a fluviatile and flood-plain origin. Hatcher, Fraas, and recently Darton have also set forth strong reasons for fluviatile

\footnotetext{
a Preliminary report on the geology and underground-water resources of the central Great Plains: Prof. Paper U. S. Geol. Survey No. 32, 1905, pl. 35.

$b$ The history of opinion is fully traced in Davis, W. M., The fresh-water Tertiary formations of the Rocky Mountain region: Proc. Am. Acad. Arts and Sci., vol. 35, No. 17, March, 1900, pp. 346-373.

c Johnson, W. D., The High Plains and their utilization: Twenty-first Ann. Rept. U. S. Geol. Survey pt. 4, 1901, pp. 601-741; Twenty-second Ann. Rept., pt. 4, 1902, pp. 631-669.

$d$ Gilbert, G. K., The underground waters of the Arkansas Valley in eastern Colorado: Seventeenth Ann. Rept. U. S. Geol. Survey, pt. 2, pp. 553-601.
} 
or river-channel and flood-plain origin; for river-channel, backwater, lagoon, and shallow-lake origin (Fraas); for flood-plain and eolian origin (Hatcher, $1902^{a}$ ) of various portions of these scattered deposits (Darton).

Among paleontologists, Matthew $\left(1899,{ }^{b} 1901^{c}\right)$ especially attacked the lacustrine theory of the origin of the White River clay of Colorado on both paleontologic and geologic grounds, and set forth cogent reasons for a diametrically opposed eolian theory, comprising a river and flood-plain origin for the sandstones, and a partly backwater and lagoon but chiefly eolian sedimentation for the clays. His paleontologic analysis shows that the fine Oligocene clays contain chiefly the terrestrial and plains animals and thus represent overflow and stillwater formations, while the sandstones traversing these clays are contemporaneous, but contain chiefly the forest and fluviatile animals, and thus represent rapid-water (river) formations.

The paleontologic evidence taken alone strongly favors the theory of dry-land sedimentation of the so-called Oligocene clays, because the entire fauna is terrestrial, while aquatic types are wholly wanting. Thus Matthew ${ }^{d}$ concludes in favor of an eolian theory:

But the nature of the organic remains, where such have been found, seems to definitely negative the idea of any vast lake, and to favor less the theory of a series of lagoons and swamps than that of a broad, open, and comparatively dry plain, with shallow, probably wooded rivers meandering over parts of it, and deposits partly or chiefly brought by rivers, but in large part redistributed over the higher sodded grass land by the agency of the wind. This would mean an approximation to the present conditions of climate, though probably not so dry as that of the region now is.

Osborn, ${ }^{e}$ after a personal survey of the South Dakota Oligocene and lower Miocene section (see Pl. III) in 1906, in general supports the view of Matthew and Hatcher that the lacustrine theory is entirely untenable, but he holds that the eolian theory for the White River Oligocene deposits is also untenable. The chief geologic evidence against the eolian theory as applied to certain areas of the Oligocene or Brule clay (Oreodon and Leptauchenia zones) is the absolutely regular horizontal banding, miles in extent, which points to deposition in tranquil sheets of water. In fact, this banding of the light-colored finer portions of the Brule clay, and even of portions of the underlying Chadron formation, militates as strongly against the eolian theory as the paleontologic evidence militates in favor of it. These buff, horizontally banded strata are, on certain levels, abruptly traversed by grayish to greenish

a Hatcher, J. B., Origin of the Oligocene and Miocene deposits of the Great Plains: Proc. Am. Philos. Soc., vol. 41, 1902, pp. 113-132.

b Matthew, W. D., Is the White River Tertiary an eolian formation? Am. Naturalist, vol. 33, 1899, pp. 403-408.

$c$ Matthew, W. D., Fossil mammals of the Tertiary of northeastern Colorado: Mem. Am. Mus. Nat. Hist., vol. 2, pt. 7, 1901, pp. 359-368 (conditions of deposition).

d. Op. cit., 1901, p. 364.

e Tertiary mammal horizons of North America: Bull. Am. Mus. Nat. Hist., vol. 23, 1907, p. 237. 
river-channel beds of coarse materials, from 700 feet to a mile in width, with an easterly direction. The most tenable theory at present seems to be that of periodic overflow deposition in very shallow sheets of water, too transitory or seasonal to support any of the aquatic animals - such deposition as is left by the annual overflow of the Nile, for example. The nilometer at Roda shows an annual accumulation of silt of 0.12 centimeter, equivalent to 12 meters in ten thousand years, as cited by Lyons ${ }^{a}$ and by Beadnell. ${ }^{b}$

Summary. - The sum of the present opinion appears to be this: The topography of the Plains Region was in Oligocene to lower Pleistocene time, as now, level or gently undulating, not mountainous. On the gentle eastward slopes of the Rocky Mountains and the Black Hills were borne broad streams with varying channels, backwaters, and lagoons, sometimes spreading into shallow lakes but never into vast fresh-water sheets. Savannas were interspersed with grasscovered pampas, traversed by broad, meandering rivers which frequently changed their channels.

This accounts for the presence of true conglomerates, true sandstones, calcareous grits, gypsum, fine clays, fuller's earth, fine loess, eolian sands, and even, far out on the plains of Nebraska ${ }^{c}$ and Kansas, widespread deposits of volcanic dust, wind borne from distant craters in the mountains to the west and southwest. In the early Oligocene and Miocene the deposits were chiefly fluviatile or river sandstones and conglomerates interspersed with fine flood-plain or overflow deposits, perhaps locally lacustrine, partly of volcanic ashes. This interpretation is presented in Pl. III, which has, been prepared to show the actual relations of the unstratified stream-channel deposits to the finer and partly stratified surrounding deposits. These rocks still await petrographic analysis.

As the desiccation or aridity of the country increased, the mountain-fed rivers became smaller and narrower, while the eolian or loess deposits apparently became more common, beginning in the middle Miocene. The deposits also became more and more restricted in extent as the Miocene advanced. The newer river channels cut down into the older series, thus using the erosion materials a second time.

Thus geology and petrography unaided fail to complete the picture. Paleontology goes hand in hand with these sciences to restore the true picture of former conditions on the Great Plains; but far more extensive petrographic and paleontologic investigation than has as yet been made is necessary to establish a final genlogic theory.

\footnotetext{
a Lyons, H. G., The physiography of the River Nile and its basin: Survey Dept. Egypt, Cairo, 1906, pp. $313,317,334$.

$b$ Beadnell, H. J. L., The topography and geology of the Fayûm province of Egypt: Survey Dept. Egypt, Cairo, 1905, p. 80 .

c See Barbour, E. H., The deposits of volcanic ash in Nebraska: Proc. Nebraska Acad. Sci., 1894-95. The heaviest beds and the coarsest ash occur in the soutnwestern counties. Even as far east as Missourı River (Cuming County) there are beds 7 feet in thickness.
} 


\section{CHAPTER II.}

\section{TIME CORRELATION OF MAMMAL-BEARING HORIZONS.}

\section{THE TWO GRAND PROBLEMS.}

American correlation.-The first problem is the chronologic correlation of the purely fresh-water American horizons with one another, a problem which in exact form has hitherto made slow progress owing to the very loose methods of collecting fossils for purely anatomic and descriptive purposes without closely recording geologic levels and other geologic data. Now, thanks to the revival of the more exact methods which characterized some of Hayden's and Leidy's work on the Great Plains, there is promise of very rapid progress. Among paleontologists we are indebted to Scott, Wortman, Matthew, Gidley, Merriam, Sinclair, and others, but especially to Matthew's very accurate and complete manuscript faunal lists. ${ }^{a}$ Accurate faunal leveling began with Hatcher's explorations of the Chadron formation (Titanotherium zone), and has been the invariable rule of the American Museum expeditions since 1901.

American and Eurasiatic correlation.-The second problem, following especially Cope (1879-1884), Marsh (1891), Filhol (1885), Scott (1888-1894), and Osborn (1900), is the approximate chronologic correlation of American horizons with Eurasiatic vertebrate horizons and thus indirectly with European marine invertebrate horizons, which is rendered possible by the well-known alternation of marine and fresh-water horizons over large parts of central Europe. This indirect method of correlation with the European marine stages is facilitated by the partial alternation of marine and fresh-water formations in Florida, as studied by Dall, ${ }^{b}$ and will in time establish the western American Tertiaries in the geologic world time scale.

When these two grand problems of American correlation and of American-Asiatic-European-African correlation are worked out we shall be able (1) to establish a complete and very accurate geologic

$a$ The most thorough previous correlation of the American Tertiaries is that of Matthew, A.provisional classification of the fresh-water Tertiary of the West: Bull. Am. Mus. Nat. Hist., vol. 12, 1899, pp. 19-75. At this writing a second edition is in preparation, the partly completed manuscript of which has been placed at my service by Doctor Matthew. It will be printed herewith as an appendix.-H. F. O. (See pp. 91-120.)

$b$ Dall, W. H., Geological results of the study of the Tertiary fauna of Florida, 1886-1903: Trans. Wagner Free Inst. Sci., Philadelphia, vol. 3, pt. 6, 1903, pp. 1541-1620. Also, A table of the North American Tertiary horizons, correlated with one another and with those of western Europe, with annotations: Eighteenth Ann. Rept. U. S. Geol. Survey, pt. 2, 1898, pp. 323-348. 
time scale for the entire Tertiary and (2) to speak with precision regarding the time of successire migrations, and it is possible that we shall be able (3) to describe our subdivisions in the terms of the stages or étages emplored by our European confrères. These are results toward which the writer has worked for many rears in cooperation with manr colleagues in this country and in Europe. ${ }^{a}$

\section{METHODS OF CORRELATION.}

Bases. - The faunistic bases which the writer laid down ${ }^{a}$ for European and American correlation were:

1. Percentages of common genera and species. To this families should now be added.

2. Similar stages of detailed erolution in related forms, e.. ., Eocene Equidæ, Miocene Rhinocerotidæ.

3. Simultaneous introduction of new forms br migration, e. g., Mastodontinæ in middle Miocene.

4. Predominance or abundance of certain forms, e. g.. Promerycocharus in all lower Miocene deposits.

5. Convergence and divergence of faunæ in comparison with Europe and Asia, e. g., lower Eocene, Oligocene, middle Miocene, middle Pleistocene.

6. Extinction of certain forms, e. g.. Stenenfiber, in lower Miocene.

Similarly the correlation of the Tertiaries of northwestern America, inter se. should be based on-

1. Presence of similar specific and generic stages.

2. Evidence of similar local erolution.

3. Dominance or scarcity of similar animals in the fauna.

4. Disappearance or apparent extinction of similar forms.

5. First appearance of similar forms.

It should alwars be kept in mind that the appearance of a new mammal in any of the Plains or Mountain deposits may occur br migration from one of several possible sources, namelr:

1. From the unknown Plains or Mountain regions of eastern North America or of northern North America.

2. From Europe or Eurasia as a whole.

3. From South America.

4. From Africa.

5. From Australia ria Antarctica.

Sources of error.-This kind of evidence as to the bases of correlation is subject to two great limitations:

First, imperfections in our records, or the possible presence of animals which hare existed in contemporaneous, earlier, or later

a Correlation hetween Tertiar? mammal horizons of Europe and America: Ann. Tew York Acad. Sci., rol. 13. 19:0, pp. 3-44. Also. Trial sheets of trpical and homotaxial Tertiary horizons. issued in 1:a: 1.05 and $190 \mathrm{ij}$. 
geologic stages, but which have not been discovered, owing to the accidents of deposition or to occurrence remote from centers of deposition. We are too apt to assume the absence of a mammal from the entire continent because it has not been found in what was formerly a very restricted region. Many forms previously considered absent from the American Eocene have very recently been discovered; for example, the animals related to the armadillos or Dasypodidæ, found in the Bridger.

Second, the different contemporary conditions of environment and habitat in different parts of the Mountain Region and of the Great Plains Region; that is, local differences of habitat, differences of longitude or of east and west distribution, differences of latitude or of north and south distribution, differences of altitude or vertical distribution-in short, such differences as exist to-day-render correlation somewhat uncertain. Thus, the arboreal primates are very common in the Eocene Mountain deposits, but no trace of them is found in the Oligocene Plains deposits.

\section{PRELIMINARY CORRELATION OF THE EOCENE AND OLIGOCENE MOUNTAIN DEPOSITS.}

Correlation of the Mountain Region basins of the Eocene is of necessity almost exclusively paleontologic owing to the uniform repetition of similar geologic and petrographic conditions in the successive basins.

These deposits, as above noted, fortunately overlapped each other in time - that is, before one ceased, its more or less distant neighbor began. The writer and others are now collecting cxact data for estimating these overlaps. Fig. 1 presents the writer's preliminary correlation of the Eocene and Oligocene deposits, based on personal studies, with the able cooperation of Matthew, Granger, Sinclair, Loomis, and others.

The chief omissions, which will soon be supplied, are (1) the Fort Union section of south-central Montana (Douglass, 1902), with its fauna equivalent to the Torrejon; (2) the typical Wasatch (Coryphodon zone) section, Evanston, Wyo. (Veatch, 1907); and (3) the typical Wind River section (Loomis).

PRELIMINARY CORRELATION OF THE OLIGOCENE TO LOWER PLEISTOCENE MOUNTAIN AND PLAINS DEPOSITS.

The geologic and paleontologic correlation of the Great Plains deposits above the lower Miocene is even more difficult owing (1) to the irregular nature of these deposits and (2) to our present lack of exact analysis of the mammalian fauna.

The accompanying preliminary correlation (fig. 10), based on the researches of Hayden, Leidy, Cope, Scott, Wortman, Merriam, 
Gidley, Douglass, Peterson, Sinclair, and others, was prepared by Dr. W. D. Matthew (May, 1906), and embodies some alterations by the writer and by Messrs. Peterson and Douglass (September, 1906). It is to be regarded as largely tentative and incomplete.

Figs. 1 and 13 bring out the following two facts of chief importance: First, that through examination and comparison of the fauna of local horizons we shall probably be enabled to establish a complete continuity of mammalian life for the entire Eocene, Oligocene, and Miocene epochs of North America in a general sense, but this will never apply to the fauna of the whole Tertiary of either the Great Plains or the Mountain Region.

Second, that while the chief faunistic lacunæ at present are in the American Pliocene, these gaps will probably be filled as time goes on, just as the great lower Miocene gaps which existed only a few years ago have been filled. 
CHAPTER III.

WESTERN AMERICAN CENOZOIC HORIZONS.

EOCENE.

I. FIRST FAUNAI PHASE.

Archaic Mesozoic mammals with partly South American, partly European affinities.

POST-CRETACEOUS OR BASAL EOCENE (EUROPE, ÉTAGE THANÉTIEN). a

1. PUERCO FORMATION; POLYMASTODON ZONE.

(Fig. 1; Pl. I.)

HOMOTAXIS.

North America.-Puerco formation (500 feet), San Juan basin, northwestern New Mexico.

South America.-A contemporary or previous (i. e., Cretaceous) land connection with South America is indicated by the occurrence of similar mammals in the Notostylops zone, Upper Cretaceous or basal Eocene of Patagonia. Additional evidence of South American connection is afforded by the subsequent occurrence of animals related to the Edentata-Dasypoda in the American middle Eocene.

Europe.-No European mammal fauna of this earliest stage is known, therefore no conclusions as to homotaxis can be drawn. It corresponds broadly to the Thanétien.

\section{FAUNA. ${ }^{b}$}

In New Mexico and Montana are found small archaic mammals ${ }^{c}$ evolving from Cretaceous, Jurassic, and Triassic ancestors. Multituberculata, which originated in the Triassic, 3 families. Two orders of archaic ungulates-(1) Amblypoda-Periptychidæ, (2) Condylarthra-Phenacodontidæ. Archaic Carnivora-Creodonta, 3 families: (1) Oxyclænidæ, (2) Mesonychidæ-Triisodontinæ, (3) Arctocyonidæ

$a$ Throughout this paper the French stages Thanétien, Sparnacien, etc., are inserted merely to indicate approximate homotaxis with Europe.

b Matthew, W. D., A revision of the Puerco fauna: Bull. Am. Mus. Nat. Hist., vol. 9, 1897, pp. 259-323. (See Appendix to this volume, p. 91.)

$c$ In the following pages "Archaic mammals" include members of the orders Multituberculata, Marsupialia, Insectivora, Tæniodonta-Edentata, Amblypoda, and Condylarthra, of Mesozoic origin (hence Meseutheria Osborn) and typically of Mesozoic and early Eocene radiation. "Modernized mammals" include members of the orders Primates, Carnivora, Fissipedia, Rodentia, Hyracoidea, Proboscidea, Perissodactyla, and Artiodactyla, which are in general of higher type and of Cenozoic origin and radiation (hence Ceneutheria Osborn).

$$
\text { 56092-Bull. } 361-09-3
$$


(Clænodon protogonoides). Edentata-Tæniodonta, with enameled teeth, 2 families: (1) Stylinodontidæ, (2) Conoryctidæ.

\section{Summary of genera and species.}

Archaic Triassic mammals......................... $33_{5}$

Archaic Cretaceous mammals ......................... $15 \quad 24$

Total archaic mammals..................... $18 \quad 29$

Modernized or distinctively Tertiary mammals ........... $0 \quad 0$

The Puerco is a fauna wholly of Mesozoic origin, and mostly destined to disappear; not a single representative or ancestor of any existing order of Tertiary mammals is certainly known. Cope's opinion $^{a}$ that many of these mammals were ancestral to the modernized mammals lacks direct confirmation at present. Other paleontologists, however, are inclined to connect certain of the creodont families with the modern Carnivora. These and other ancestral connections may be demonstrated in future.

Negatively, therefore, the Puerco is distinguished by the absence of primates, rodents, true carnivores, specialized insectivores, artiodactyls, perissodactyls, etc. ${ }^{b}$ This generalization has hardly less important bearings on paleogeography than on paleozoology.

\section{TORREJON FORMATION; PANTOLAMBDA ZONE.}

(Fig. 1; Pl. I.)

HOMOTAXIS.

North America.-1, Torrejon formation (300 feet), continuous with Puerco formation, San Juan basin, northwestern New Mexico. 2, A portion of the Fort Union formation, Montana (Douglass, ${ }^{c}$ Farr).

Europe.-Thanétien or Cernaysien. Homotaxis with Europe is indicated by the common presence in France and North America of similar stages of evolution in representatives of 3 families, namely, (1) Plagiaulacidæ, (2) Arctocyonidæ, and (3) Mesonychidæ-Triisodontinæ. Other identifications are very uncertain. ${ }^{d}$

\section{FAUNA. ${ }^{e}$}

Like the Puerco, this is ahmost exclusively a Mesozoic fauna, destined to become extinct during the Eocene. The known excep-

$a$ The opposite theory of the nonancestry of the Puerco-Torrejon to the modern fauna was developed by the writer, in Rise of the Mammalia in North America: Proc. Am. Assoc. Adv. Sci., vol.42, 1893 (1894), p. 214. See also Ten years' progress in mammalian paleontology: Compt. Rend. 6o Cong. intern. zoologie, Berne, 1904, pp. 86-113.

$b$ Certain incompletely known mammals (e. g., species of Mioclænus and Pentacodon, of the Oxyclænidæ and Mixodectidæ) may prove to be Insectivora.-W. D. M.

c Douglass, Earl, A Cretaceous and lower Tertiary section in south-central Montana: Proc. Am. Philos. Soc., vol. 41, pp. 207-224. Also, New vertebrates from the Montana Tertiary: Ann. Carnegie Museum, vol. 2, 1903, pp. 145-200.

d Osborn, H. F., A review of the Cernaysian Mammalia: Proc. Acad. Nat. Sci. Philadelphia, May 6, 1890 , pp. 51-62.

$e$ Matthew, W. D., A revision of the Puerco fauna: Bull. Am. Mus. Nat. Hist., vol. 9, 1897, pp. 259-323, (See Appendix to this volume, p. 91.) 
tions in surviving types are the pro-Carnivora-Miacidæ, which first appear at this stage. Others will be discovered.

Mammals of larger size, mostly evolved from the Puerco mammals. Last survivors of the Multituberculata. Edentata-Tæniodonta of larger size. Of archaic Ungulata, 2 orders and 3 families: (1) Condylarthra-Phenacodontidæ, (2) Amblypoda-Periptychidæ, (3) Amblypoda-Pantolambdidæ. Of the latter, Pantolambda is supposed to be ancestral to the Coryphodontidx of the Wasatch. Carnivora-Creodonta, 4 families: (1) Mesonychidx-Triisodon and Dissacus, (2) Oxyclænidæ, (3) Arctocyonidæ, (4) pro-Carnivora-Miacidæ. The primatelike Indrodon and aberrant Mixodectes are of unknown relationships; they are possibly Insectivora.

Summary of genera and species.

\begin{tabular}{|c|c|c|}
\hline Archaic Triassic stock.................... & $\begin{array}{c}\text { Genera. } \\
\quad 3\end{array}$ & $\begin{array}{l}\text { Species. } \\
\quad 4\end{array}$ \\
\hline Archaic Cretaceous stock.... & 21 & 36 \\
\hline Total archaic stock......... & 24 & 40 \\
\hline Modernized Tertiary stock ........... & 1 & 1 \\
\hline
\end{tabular}

\section{SECOND FAUNAL PHASE.}

First modernization-Invasion of the archaic by the modern fauna-South American land connection interrupted-Close faunal connection with western Europe-Initial elimination of the archaic fauna in competition with the modern.

In the period of the deposition of the Wasatch formation, independent deposits were formed in western Wyoming, northern Wyoming, and New Mexico. A momentous change occurs, namely, the sudden modernization of the mammalian fauna of the Mountain Region.

In the San Juan basin of northwestern New Mexico, after a barren deposition interval of only a few hundred feet between fossiliferous Torrejon and Wasatch levels (see fig. 1), there appear representatives of ancestors of 4 or 5 modern orders, including 11 new families, 2 of which persist to the present time. European paleontologists usually attribute the origin of this modernized fauna to North America, but this is without evidence; it is certain that it originated neither in South America nor in Africa. There remain four possible sources; these animals may have entered the central Mountain Region by migration (1) from the Great Plains Region, or (2) from the more northerly American Mountain Region, or (3) from the northerly Eurasiatic Region, or (4) from the northerly AmericanAsiatic land mass.

In the writer's judgment, the simultaneous and sudden appearance in North America, latitude $40^{\circ}$, and in western Europe, latitude $50^{\circ}$, of a similar fauna favors the fourth theory, namely, that of the intermediate or North American-Asiatic or Holarctic origin of this 
fauna. It must be remembered that while there is no evidence of a "Holarctica," or north polar continent, similar to the "Antarctica" in the south, there was certainly a great American-Asiatic land mass to the north, of temperate climate, favorable to the evolution of mammalian life. The vast region between parallels $50^{\circ}$ and $70^{\circ}$ is also a terra incognita until the mid-Pleistocene. There is every reason to believe that even to the north this region was through the whole pre-Pleistocene Tertiary highly favorable to mammalian life, otherwise the faunal continuity between Europe and western America could not have been sustained by constant intermigration. Wort$\operatorname{man}^{a}$ and others have especially advocated the theory of a northerly or Arctic Circle land mass as a source of evolution and southward migration.

The actual origin of this modernized fauna which suddenly appears in North America and Europe is, however, hypothetical and will not be determined until Eocene fossil mammal beds in northern portions of America and Asia shall have been discovered.

\section{LOWER EOCENE (EUROPE, ÉTAGES SPARNACIEN, YPRÉSIEN).}

3. WASATCH FORMATION; CORYPHODON ZONE.

(Figs. 1-4; Pl. I.)

\section{HOMOTAX1S.}

North America.-1, Typical Wasatch (in part), Knight formation, Veatch (1,750 feet), western Wyoming. 2, Wasatch near Black Buttes, Washakie basin, Wyoming. 3, Wasatch of the San Juan basin of northern New Mexico (1,500 feet). 4, Wasatch of the Bighorn Basin of northern Wyoming (2,391 feet, Loomis). 5, Lower portion of the Huerfano formation near Spanish Peaks, Colorado.

South America.-No South American affinities are known.

Europe.-Strong affinities with the fauna of the étage Sparnacien and especially with that of the étage Yprésien (Londinien) of France are found in the evolution of the archaic and in the sudderi appearance of the modernized Mammalia of this period.

The Sparnacien (Soissonais inférieur) includes in France the deposits of Soissons, Meudon, and Vaugirard; in England, the Woolwich beds and lower London clay. The Yprésien (or Soissonais supérieur) of France includes deposits of Ay and Cuis. It is in this stage that the European modernization becomes marked by the sudden appearance of Primates, Rodentia, 2 families, PerissodactylaLophiodontidæ and Artiodactyla-Dichobunidæ. The Lutétien inférieur of France corresponds approximately with the American upper part of the Wind River.

$a$ Wortman, J. L., Studies of Eocene Mammalia in the Marsh collection, Peabody Museum; Part II, Primates: Am. Jour. Sci., June, 1903, 4th ser., vol. 15, pp. 419-436. 
The general parallelism of France, England, and North America is indicated (1) by the common presence in this period of similar

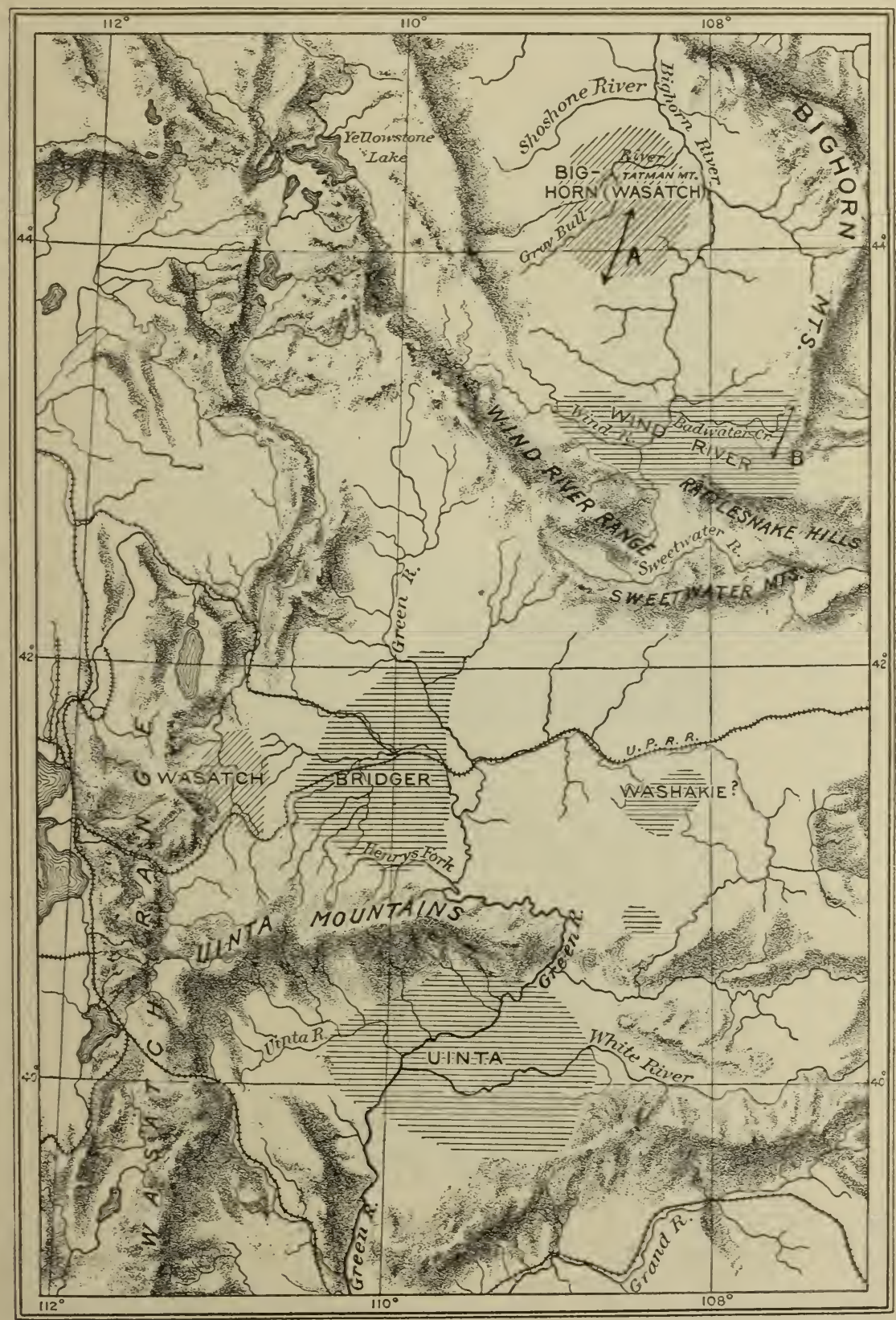

FIG. 2.-Map of southwestern Wyoming and northern Uteh, showing partial areas of the Wasatch Wind River, Bridger, and Uinta formations. Extensive areas of the Wasatch are purposely omitted. A, B, lines of sections by F. B. Loomis.

stages in archaic mammals-among Creodonta: Mesonychidæ, Palæonictidæ, ?Arctocyonidæ, and Oxyænidæ; among Amblypoda: Cory- 
phodontida: (2) by the sudden appearance of the four Tertiary orders. (a) Perissodactyla-Equidae ${ }^{a}$ and -Lophiodontida, (b) Artiodactyla, (c) Primates. and (d) Rodentia.

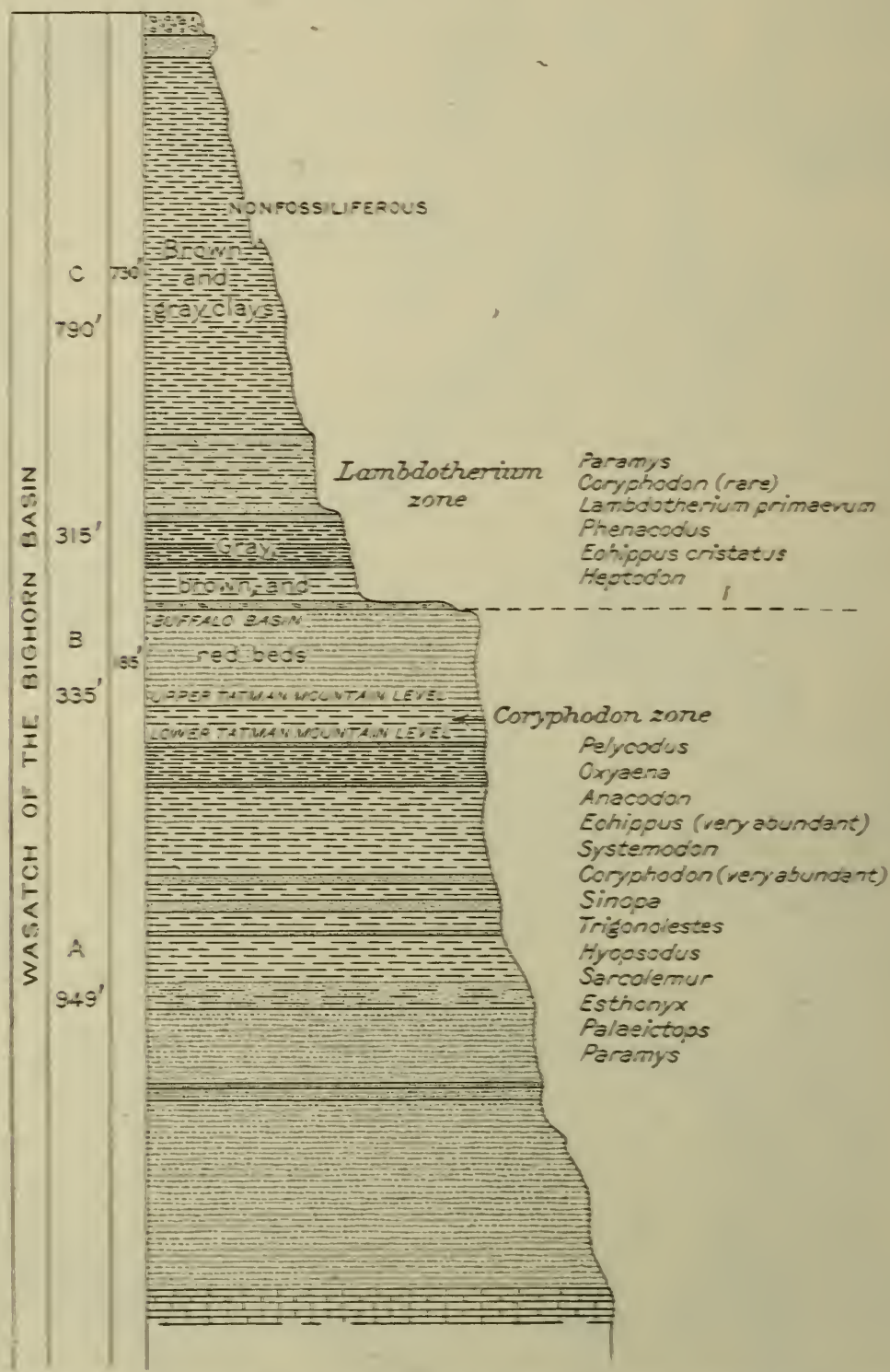

FY. 3-lomposite columns sation of the Wasatch formation of Bighorn Basin. compile I from settims by F. B. Loomis. See section A. fig. 2. Total thichneas 2391 feet.

Other faunal identifications with Europe are premature. With the exception of the archaic and modern families abore listed, the European families and subfamilies are different from the American so far

- The Equilue of the Sparacien are more primitive than the oliest Wasuth spmies. 
as known. H. G. Stehlin ${ }^{a}$ supports the writer's opinion that Rütimeyer was too prone to identify European with American genera;

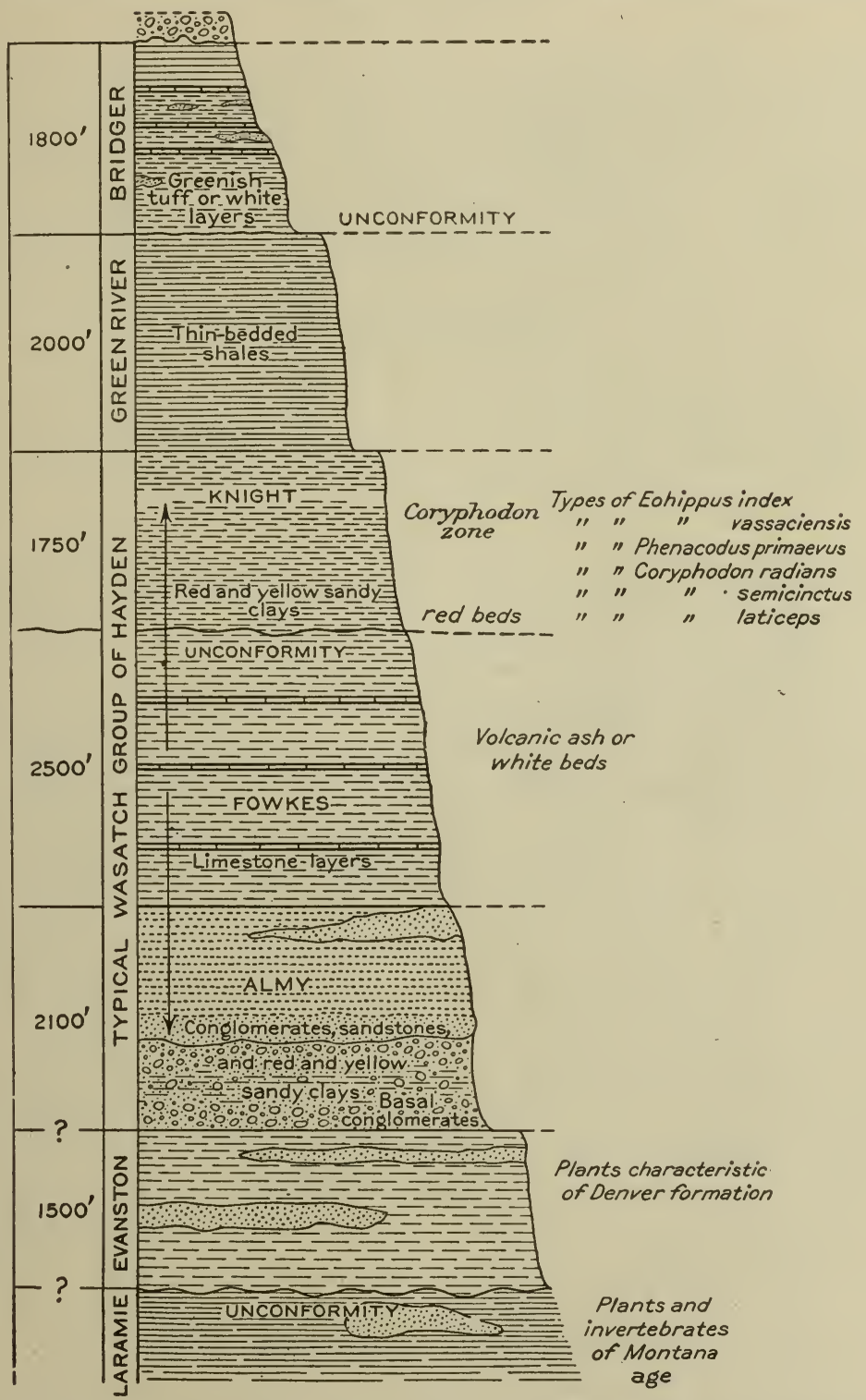

-FIG. 4.-Columnar section showing the relations of the typical Wasatch section, including the Knight formation (near Knight, Wyo.), or Coryphodon zone, to the overlying and underlying formations. After Veatch, 1907.

this removes the American resemblances supposed to exist in the Egerkingen fauna, which now proves to be of middle Eocene (Luté-

$a$ In letter dated July, 1906, Doctor Stehlin states that he is himself engaged in the study of migrations. He, too, finds strong evidence (1) for a lower Eocene connection between America and Europe, (2) for a very decided separation during the middle and upper Eocene, and (3) for a renewed connection in the Oligocene and a great Oligocene faunal interchange. These are substantially the views adopted in the present paper. 
tien) age. The supposed "americoids." Calamodon, Phenacodus, Euprotogonia, Hyopsodus. Pelycorlus, etc., are all European animals.

\section{FACXA. ${ }^{a}$}

The Tasatch fauna consists of a nearly equal or half-and-half mingling of (1) archaic mammals, including 9 families which erolved from the Puerco-Torrejon fauna, with (2) ancestors of the modernized mammals, including 11 families. From this stage onward we have to consider these two great elements in the fauna separately.

\section{Summary of genera.}

Persistent Triassic mammals.......................... 0

Other $\operatorname{archaic} b$ mammals............................

Monlernized mammals.......................... 16

There is thus at this period a slight predominance in number of the archaic mammals orer the modernized. but the individual archaic mammals greatly predominate in size.

The sumiving archaic or Puerco-Torrejon mammals.-Some of these mammals, such as Coryphodon, are of large size. The Multituberculata disappear. Of the Edentata-Tæniodonta, 3 genera of the Stylinodontidæ. Of the archaic ungulates, 2 orders and 3 families are represented: (1) Amblypoda-Coryphodontidæ, as successors to the Pantolambdidæ; (2)Condylarthra-Phenacodontidæ: (3) CondylarthraMeniscotheriidæ. Of the Creodonta-Carnirora there occur 5 families, namely, Palæonictidæ, Oxyænidæ, Hyænodontidæ, Mesonychidæ, and Arctocronidæ; 4 of these families also occur in France.

The Tertiary or modernized mammals.-These mammals are mostly of small size, including the successors of the supposed Torrejon proCarnirora-Miacidæ, a family which now branches out into sereral genera. No other Carnirora. True Primates, 2 families. Rodentia, 1 genus, Paramys with sciuroid teeth. Insectirora, 2 or 3 families, one of doubtful affinity. Among Ungulata-Perissodactryla, 3 families, Equidæ, Tapiridæ, Lophiodontidæ. Among Ungulata-Artiodactyla, 1 family. There are thus 11 families among the modernized mammals, only two of which (Equidæ and Tapiridæ) persist to the present time.

a Osborn H. F., and Wortman. J. L., Fossil mammals of the Wasatch and Wind Rirer beds: Bull. Am. Mus. Nat. Hist., rol. 4. 1692, pp. \$1-14i.

Loomis, F. B. Origin of the Wasatch deposits: Am. Jour. Sci., May, 1907, 4th ser, rol. 23, pp. 356-364. See Appendix. p. 91.

$\checkmark$ See footnote, p. 33. 


\section{3a. WASATCH OF THE BIGHORN BASIN.}

(Figs. 1-3; Pl. I.)

Loomis $^{a}$ examined the Wasatch of the Bighorn Basin when the question of epicontinental versus lake deposition was uppermost in the minds of all. By a careful analysis of the fauna, combined with an exact study of the geologic section, he dismisses the lake theory entirely. Geologically, as displayed in fig. 3, the section is 2,391 feet thick, divided into lower, middle, and upper levels, all showing flood-plain rather than eolian characteristics, but indicating different rates of deposition and consequent longer or shorter exposure of the deposits to the sun and air. Only the middle or red beds are decidedly fossiliferous, and they seem to have been exposed longest to the air, leaving the bones of terrestrial animals on the flats; they contain the typical Wasatch, Coryphodon and Eohippus fauna. Occasionally truly aquatic animals, such as crocodiles, fishes, and turtles, becoming stranded or inclosed in lagoons far from the river, mixed their remains with those of the land animals. Loomis's approximate analysis of the natural habitat of the total vertebrate fauna is: Aerial, 3 per cent; terrestrial and arboreal, 77 per cent; amphibious, 12 per cent; aquatic, 10 per cent.

Remains of Eohippus, typical of a plains or partly open country, alone make up 32 per cent of the total fauna. To this should be added the Perissodactyla-Lophiodontidæ-Helaletinæ (Heptodon), and some of the Condylarthra-Phenacodontidæ, which are very lightfooted forms. The primitive Titanotheriidæ (Lambdotherium) of the period may have been hard-ground dwellers, because their feet are more slender and contracted than those of the modern tapir, while the Amblypoda-Coryphodontidæ were certainly marshy-land dwellers and perhaps partly amphibious or stream dwellers, although this is far from demonstrated. As to relative age, Loomis fixes very positively the typical American Wasatch fauna, or chief Eohippus and Coryphodon zones of Tatman Mountain, as only 100 to 200 feet below the beds of the Buffalo basin. The deposits in the Buffalo basin show; 1,000 feet below the summit, a decided approach if not actual synchronism to the lower deposits of the Wind River valley in the presence of Lambdotherium and in the progressive evolution of the Equidæ. Thus there is a prolonged time overlap between the deposits of the Bighorn and those of Wind River. (See fig. 1, p. 23.) 


\section{THIRD FAUNAL PHASE.}

Absence of fresh Eurasiatic or northern migration-Continuation of similar environmental conditions-Descendants of the archaic and modernized mammals slowly evolving and competing with one another during the lower and middle Eocene-Gradual elimination of the archaic mammals-Gradual divergence from the fauna of western Europe, and little evidence of faunal interchange-Establishment of North American Ungulata-Artiodactyla.

First, as to progressive divergence from Europe, it appears that by the middle and upper Eocene stage there were 13 non-European families of mammals in America and 11 non-American families of mammals in Europe, as against 4 European-American families common to the two regions. This independent and divergent evolution was not sufficiently emphasized until suggested by the writer in 1899. ${ }^{a}$ It points to the existence of prolonged geographic or climatic barriers between the two continents.

Second, as to the continuously uniform conditions in the Mountain Region, Matthew has especially called attention to the prolonged uniformity of life, alike as to families, genera, and species, throughout the Wasatch, Wind River, Huerfano, and lower Bridger depositions. To this uniformity may be added the Uintatherium zone of the Bridger and Uinta basins; in other words, the uniformity extended from the lower to the upper Eocene. The changes are those of modification and development rather than of breaks in the balance of nature by migration and extinction.

Our conclusions are as follows: (1) Environment: Uniform and favorable environmental conditions prevailed during this long period in the Mountain Region, with the competition and balance of nature somewhat in favor of the modernized families, all of which persisted, while 5 families of the archaic mammals disappeared. (2) Evolution: Both the archaic (Cretaceous) and the modernized mammals increased in size and in variety; the changes are chiefly specific rather than generic. (3) Gains and losses: Two archaic families of Ungulata, Condylarthra-Phenacodontidæ and Amblypoda-Coryphodontidæ, appeared for the last time (Wind River); 1 new archaic family, the Amblypoda-Uintatheriidæ, appeared (Wind River); 2 families of archaic Carnivora-Creodonta have disappeared (Wasatch), namely, Palæonictidæ, Arctocyonidæ; ${ }^{b}$ the progressive Carnivora-Miacidæ are represented by 5 genera; 1 new family of Ungulata-Perissodactyla

a Osborn, H. F., Correlations between Tertiary mammal horizons of Europe and America, etc.: Ann. New York Acad. Sci., vol. 13,1900, p. 18. "Fourth, the Ligurien is widely distinct faunally from the American upper Eocene or Uinta, with which it has been heretofore paralleled. At no period of the Tertiary were the Nearetic and Paiæarctic faunæ so widely separated. In fact, a much wider gap exists between western America and Europe in the upper Eocene than in the preceding lower and middle Eocene or in the succeeding lower Oligocene."

$\checkmark$ Matthew considers that the Arctocyonidæ should not be placed among the archaic mammals, but rather that they represent an eally branch of the Pro-Carnivora. 
appeared (Wind River), namely, the Titanotheriidæ, possibly entering from the Great Plains Region to the east; 1 new family related to the Edentata-Dasypoda, or armadillos, appeared (Bridger), probably from the southern Great Plains Region and originally of South American origin before the Cretaceous land connection was interrupted.

ILOWER TO MIDDLE EOCENE (EUROPE, ÉTAGES YPRÉSIEN, LUTÉTIEN INFÉRIEUR).

4. WIND RIVER FORMATION; ${ }^{2}$ LAMBDOTHERIUM AND BATHYOPSIS ZONES.

(Figs. 1-2, 5; Pl. I.)

HOMOTAXIS.

North America.-1, Wind River formation, Hayden, of northern Wyoming (1,200-1,400 feet). 2, Upper half of the Wasatch of the Bighorn Basin. 3, Lower part of Huerfano formation, Hills, of Colorado (200? feet).

Europe (provisional).-The lower part of the Wind River is partly equivalent to the Yprésien of France. The upper part of the Wind River is approximately equivalent to the Lutétien inférieur of France.

\section{FAUNA. ${ }^{b}$}

The mammals of the Wind River deposition are less fully known than those of either the Wasatch or the Bridger. So far as these three faunæ can be separated at present, the lower Wind River presents closer affinities to the Wasatch, while the upper Wind River presents closer affinities to the Bridger. The balance of life between the archaic and the modernized mammals continues to be nearly even.

\section{Summary of genera.}

Archaic or Cretaceous mammals...................... 17

Modernized or Tertiary mammals.................... 17

Faunal sequence to the Wasatch.-Partial faunal continuity with, and partial sequence in time to, the Wasatch is sustained (1) by the presence of 19 genera in common with the Wasatch, (2) by the rarity or absence of a few Wasatch animals, (3) by the occurrence of more advanced (or post-Wasatch) stages of evolution in a large number of descendants of animals which persist from the Wasatch, (4) by

$a$ This section has been revised by Prof. F. B. Loomis, the most recent explorer of this basin.

$b$ Loomis, F. B., Origin ot the Wasatch deposits: Am. Jour. Sci., May, 1907, 4th ser., vol. 23, pp. 356-364. Cope, E. D. The badıands of the Wind River and their fauna: Am. Naturalist, vol. 14, 1880, pp. 745-748. See Appendix, p. 91. 
the significant fact that some of the more advanced stages occur in the base of the Wind River deposition, (5) by the introduction of true primitive Dinocerata or uintatheres, of primitive titanotheres, of new Primates, which are not found in the Wasatch, and of more highly specialized Tæniodonta (Stylinodon).

The writer's conclusions at present are (1) that the base of the Wind River, or Wind River A, began to be deposited during the upper stage of the Wasatch deposition of the Bighorn Basin (see p. 41),

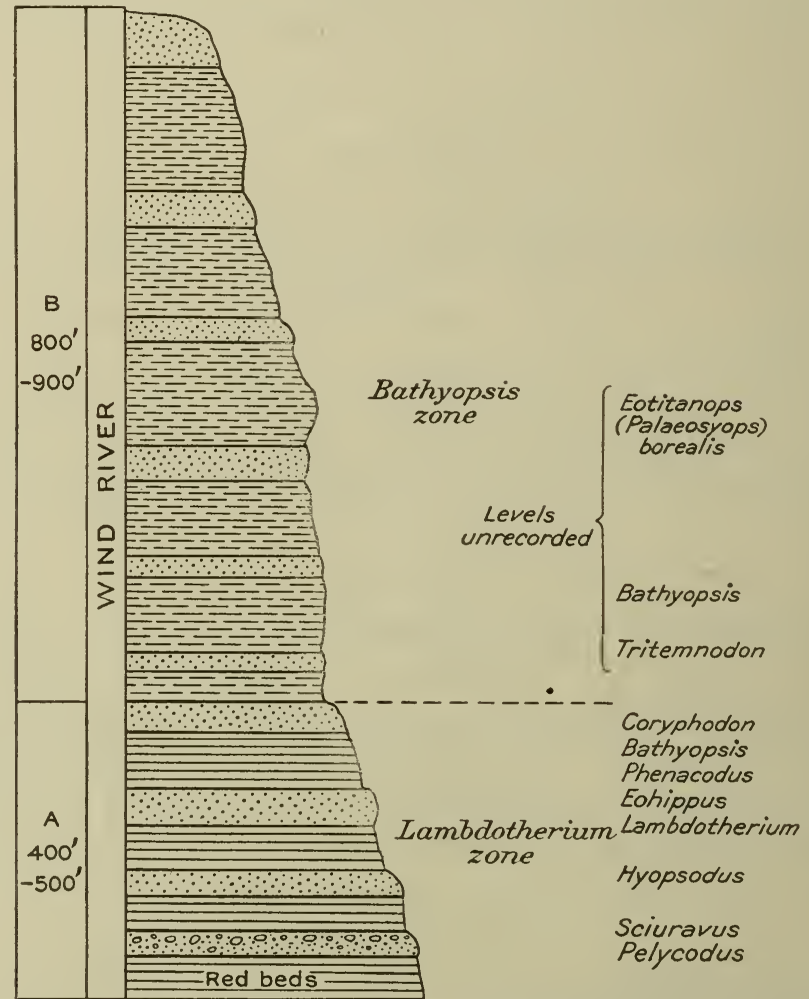

FIG. 5.-Columnar section of the Wind River basin, based on the descriptions of Hayden and Loomis. The horizontal banding of the red and greenish-gray beds in Wind River B is very regular. The occurrence of Eotitanops and Bathyopsis in the upper Wind River is not certainly recorded.

and was thus contemporaneous with most of the upper fossil-bearing strata of the Bighorn Basin Wasatch; (2) that positive evidence of an overlap may be derived from the study of the faunæ; (3) that the Lambdotherium zone occurs in each.

Geologic divisions.-Hayden's exploration of 1859-60, as reported in $1869,^{a}$ afforded materials for the first complete section we have of the Wind River Tertiaries. His "lower division," of 400 to 500

a Geol. Rept. Explor. Yellowstone and Missouri Rivers, by F. V. Hayden, assistant [to Col. William F. Raynolds, U. S. Engineers], Washington, 1869. 
feet, which we may designate Wind River $\mathrm{A}$, is largely fossiliferous and has yielded most of the important forms found in successive explorations by Wortman ${ }^{a}$ (1891), Granger (1905), and Loomis ${ }^{b}$ (1907). Hayden assigned 1,200 feet to an "upper division," which we may designate Wind River B. This is now believed to contain fossils of a higher type, although the field records are not quite clear and fossils are scarce.

Preliminary faunal divisions.-(A) Wind River, lower 500 feet, re! beds. Lambdotherium zone. Contains Coryphodon, Phenacodus, Eohippus, Lambdotherium, etc. (B) Wind River, upper 800 feet. Bathyopsis zone. Contains Coryphodon, Phenacodus, also Bathyopsis Palxosyops borealis (= Eotitanops).

The B stage approximates the middle Eocene, or Lutétien inférieur of France (Argenton, the older Lissieu and older Egerkingen fissureformation faunæ), and the Bracklesham of England.

General faunal characters of the Wind River.-Since the faunal levels which undoubtedly distinguish Wind River A and B have not yet been clearly separated, we must consider the fauna chiefly as found on the lower levels, or red beds. First it must be made clear that the Wind River, as compared with either the Wasatch or the Bridger, is a relatively barren formation and has not been so fully explored.

Archaic or Cretaceous fauna: Of the ancient fauna the Creodonta are represented by 4 families, the members of which are incompletely known. Of these the genera (a) Hapalodectes and Pachyæna (Mesonychidæ), (b) Tritemnodon (Hyænodontidæ), and Oxyæna (Oxyænidæ) are somewhat more advanced than Wasatch forms; (c) Limnocyon, a primitive, and Patriofelis, a specialized member of the Oxyænidæ, appear for the first time, animals which are very characteristic of the Bridger; (d) Anacodon represents the Arctocyonidæ.

Among the Tillodontia the Wasatch genus Esthonyx persists, and among Tæniodonta (Edentata?) the Bridger genus Stylinodon first appears. The Insectivora are undoubtedly represented in Palæictops (Leptictidæ), Palæosinopa (Pantolestidæ), and possibly also by several species of Hyopsodus, all in more advanced evolution stages than those in the Wasatch, but still distinct from the Bridger species. It is noteworthy that Hyopsodus attains its largest size at this time. The reported existence by Cope of Cheiroptera is an error.

The Condylarthra-Phenacodontidæ diminish and disappear. The Amblypoda-Coryphodontidæ also diminish and disappear, being replaced by the Amblypoda-Uintatheriidæ. Of Carnivora-Creodonta, the family Arctocyonidæ is represented by Anacodon (vide 
Loomis); the Palæonictidæ are represented by doubtfully referred specimens in the Wind River and lower Huerfano; the 3 certainly surviving creodont families are the Mesonychidæ, Oxyænidæ, and Hyænodontidæ. The Edentata-Tæniodonta are represented by Stylinodon; the Tillodontia by Esthonyx. A supposed marsupial, Peratherium comstocki, is reported by Cope and Loomis.

Modernized fauna: Among the modernized forms the forest-living primates first deserve notice: (a) Of the animals of larger size the Notharctidæ include Pelycodus, surviving from the Wasatch and continued into the lower Bridger; also Notharctus, a monkey very plentiful in the Bridger, now appearing for the first time; $(b)$ the specialized Anaptomorphidæ recur; $(c)$ the doubtful primates Microsyopidæ are also found.

The Rodentia are represented by the rather abundant Paramys and somewhat more rare Sciuravus. Among Insectivora, 3 families are known, namely, Leptictidæ (Palæictops), and the recently referred families Hyopsodontidæ and Pantolestidæ. The pro-CarnivoraMiacidæ, now become more diversified, including the genera Didymictis, Vulpavus, and Miacis, all found in the Wasatch, which recur here in slightly larger and more progressive forms. These animals resemble the Canidæ in dental structure and the Procyonidæ in other points. The Bridger genera Viverravus and Oödectes appear here for the first time.

Of modernized Ungulata-Perissodactyla there are now 4 families. It is noteworthy that all are represented by light-limbed slenderfooted forms, pointing to rather dry-land conditions in this region at the time. (a) The Equidæ are represented by the persisting Wasatch forms still known as Eohippus because a rudimentary fifth digit still persists in the pes and there is little advance in dentition. (b) Members of the Tapiridæ have not been found, but they undoubtedly existed. (c) The Lophiodontidæ are represented by Heptodon. (d) The newly appearing Titanotheriidæ are represented by 2 genera and 3 species.

The distinctive forms of titanotheres found in the Wind River are:

Lower part of Wind River, Lambdotherium popoagicum, of about the height of a water chevrotain (Dorcatherium aquaticum).

?Upper part of Wind River, Eotitanops borealis, of about the height of a wart-hog (Phacochœrus africanus).

?Upper part of Wind River, Eotitanops brownianus, of about the height of a young pig.

Of these animals the Lambdotherium occurs plentifully only in the upper Wasatch deposits, in the lower part of the Wind River, and in the Huerfano formation of southern Colorado. Nothing at present is known in the Wasatch which could stand ancestral to it, nor is any 
Bridger genus known which could be directly descended from the species L. popoagicum.

Of Ungulata-Artiodactyla Trigonolestes survives from the Wasatch.

WIND RIVER A; LAMBDOTHERIUM ZONE.

Period of lower deposition.-Wortman ${ }^{a}$ concluded on his second visit (1891) that the lower Wind River is absolutely distinct from the Wasatch of the Bighorn Basin and belongs to a succeeding deposition. He supposed that the Wind River country was above water during the laying down of the Wasatch sediments, and that some time after the close of the Wasatch a lake was formed on the site of the present Wind River basin. Loomis ${ }^{b}$ (1907) regards the Wind River formation as epicontinental, fluviatile, and flood-plain, like the Wasatch, and slightly subsequent in the beginning of its deposition.

General characters. - A total thickness of 400 to 500 feet near the sources of Wind River. Readily distinguished geologically by horizontally alternating bands of bright-red and gray fossil-bearing shales and sandstones containing Coryphodon, turtles (Trionyx), crocodiles (Crocodilus), Lacertilia-Anguidx (Glyptosaurus), etc. The conglomerates, indicating rapid stream or river invasions, are barren. The writer is indebted to Professor Loomis for the section (fig. 5, p. 44) and for his observations on stratigraphic distribution.

Fauna.-The chief part of the Wind River fauna listed above is from these red beds. In the lower red beds are found Coryphodon, Eohippus, Lambdotherium, and several species of Hyopsodus; among primates, Notharctus and Pelycodus. The American Museum collections of 1905 , nearly all from the red beds, exhibit a closer degree of affinity to those of the upper Wasatch than is found in specimens from the upper beds. The Amherst collections include from these beds Bathyopsis, the earliest known member of the Dinocerata.

\section{WIND RIVER B; BATHYOPSIS ZONE.}

Period of upper aeposition.-The upper levels, or Wind River B, are naturally to be compared with Bridger $\mathrm{A}$, but unfortunately too few fossils have as yet been found to afford such a basis of correlation.

Hayden (1869) described these beds as consisting of 800 to 900 feet of ferruginous, coarse-grained sandstones, alternations of sandstones and marls, light sandstones, friable sandstones, and indurated marls. They are probably in large part of volcanic-dust origin. Some of these strata indicate great disturbances in the water during their

a. Wortman, J. L., Fossil mammals of the Wasatch and Wind River beds: Bull. Am. Mus. Nat. Hist., vol. 4, 1892, pp. 143-144.

$b$ Loomis F. B , Origin of the Wasateh deposits: Am. Jour. Sci., 4th ser., vol. 23, 1907, pp. 356-364. 
deposition. Altogether the conditions were unfavorable, perhaps prohibitive, for the deposition of fossils.

Fauna.-Although not certainly recorded, it appears probable that Wind River B contains Eotitanops borealis, the second known stage in the evolution of the Titanotheriidæ, the first known stage being Lambdotherium primævum Loomis of Wind River A.

\section{4a. HUERFANO FORMATION; LAMBDOTHERIUM AND ? OINTATHERIUM ZONES.}

\section{HOMOTAXIS.}

North America.-1, Huerfano formation of Hills, 1888 (800-1,000 feet, Wortman). 2, Wind River (Lambdotherium zone) in part. 3, Lower part of Bridger formation.

The only middle Eocene deposit east of the Rocky Mountains is that of the Huerfano River basin of southern Colorado (see Pl. I), first described by Hills ${ }^{a}$ in 1888, explored by the writer and Tortman in 1897, and described by the writer. ${ }^{b}$ The basin opens into the plains immediately north of the famous Spanish Peaks. The sediments described below as marls, clays, shales, etc., will very probably prove to be of volcanic-dust origin.

The writer's present conclusion as to the age of this formation is that it began during the Wind River and continued without a break into the period of the lower Bridger formation.

\section{LOWER PART OF HUERFANO FORMATION; LAMBDOTHERIUM ZONE.}

(Homotaxis, Wind River.)

Wortman explored the immediately underlying levels to the east of Gardner, previous explorations having been made to the north and west, and was surprised to find a fauna containing none of the forms characteristic of the Bridger level (as chiefly found by Hills), but distinguished as of Wind River age by the presence of Coryphodon, Lambdotherium, Oxyæna, Trigonolestes, and other lower Eocene forms. Wortman ${ }^{c}$ says:

These beds of the lower division are indistinguishable, so far as their general appearance and lithological characters are concerned, from those of the upper level. The fossils occur apparently in a single stratum not exceeding 10 or 15 feet in thickness, and not more than 30 or 40 feet from the base of the formation. They underlie the beds of the upper division with perfect conformity, and there is at present no means of determining exactly where the one ends and the other begins. * * * The exact locality from which the greater number of the fossils of the lower beds were obtained is Garcias Canyon, about $1 \frac{1}{2}$ miles south of Talpa or the mouth of Turkey Creek.

$a$ Hills, R. C., 1888.

$b$ Oshorn, H. F., The Huerfano Lake basin: Bull. Am. Mus. Nat. Hist., vol. 9, 1897, p. 251.

cWortman, J. L., Geological and geographical sketch of the Bighorn Basin. In Osborn, H. F., and Wortman. J. L., Fossil mammals of the Wahsatch and Wind River beds: Bull. Am. Mus. Nat. Hist., vol. $4,1892, \mathrm{pp} .135-144$. 
The fauna, as originally determined and subsequently (February, 1906) reexamined by Matthew from the very small American Museum collection, is as follows:

Lower Huerfano fauna and equivalents.

$[X=$ species represented: $(X)=$ genus represented. $]$

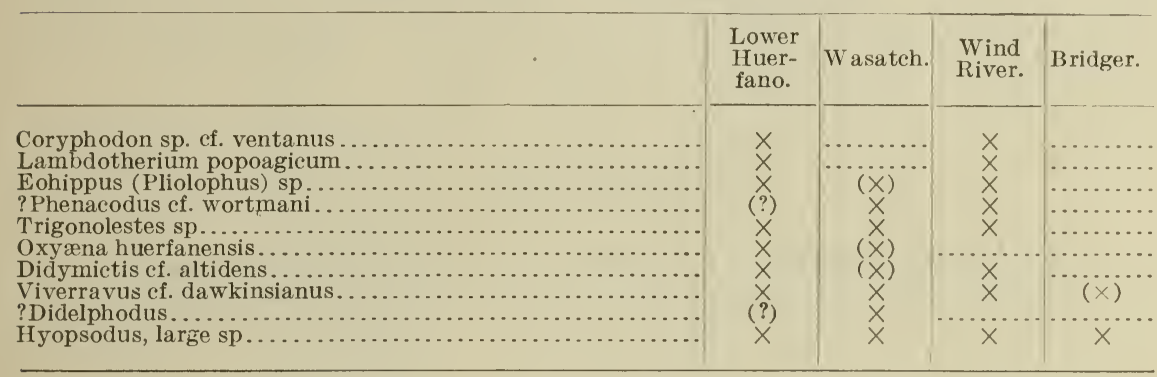

The Eohippus is more advanced than anything in the Wasatch, but distinctly more primitive than the most primitive Orohippus of the Bridger in our collections. The lower part of the Huerfano is, on this showing, homotaxial with a portion of the Wind River.

\section{UPPER PART OF HUERFANO FORMATION; ?UINTATHERIUM ZONE.}

\section{(Homotaxis, lower (?) Bridger.)}

West of Huerfano Canyon the so-called variegated marls, clays, soft shales, and sands aggregate only 800 to 1,000 feet in thickness, are nearly horizontal in position, and constitute the "upper series" of the typical Huerfano lake deposits of Hills. To the west of Gardner all the mammal remains were found in these sands, clays, and marls, varying from red, purple, gray, or green to yellow or whitish in color, the upper arenaceous clays containing the richest deposits. These deposits have not been examined lithologically; it is quite possible that they are largely composed of volcanic ash. Although the fossils are nowhere numerous, they are all of Bridger age, namely, Palæosyops, Hyrachyus, Tillotherium, and Glyptosaurus.

\section{Upper Huerfano fuana and equivalents.}

\begin{tabular}{|c|c|c|c|c|}
\hline 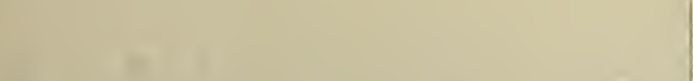 & $\begin{array}{l}\text { Upper } \\
\text { Huer- } \\
\text { fano. }\end{array}$ & Wasatch & $\begin{array}{l}\text { Wind } \\
\text { River. }\end{array}$ & Bridger. \\
\hline 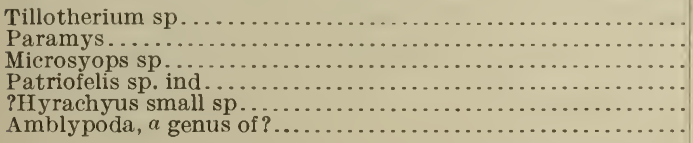 & $\begin{array}{l}x \\
x \\
x \\
x \\
x \\
(x)\end{array}$ & $x$ & $\begin{array}{l}x \\
x \\
x\end{array}$ & $\begin{array}{c}\underset{x}{x} \\
\underset{x}{x} \\
(\underset{x}{x}) \\
x\end{array}$ \\
\hline
\end{tabular}

$a$ The Amblypoda are represented by a tibia of small size which may have belonged to Uintatherium. 56092-Bull. $361-09-4$ 
It is clear that these beds must be referred to the Bridger, not to the Wind River. The Paramys compares most nearly with lower Bridger species, but is too incomplete to settle its position without very careful comparisons. There does not appear to be anything else to indicate whether these beds are equivalent to lower or to upper Bridger. The Patriofelis is a very much smaller species than P. ulta of the lower Bridger or P. ferox of the upper Bridger. The Tillotherium is a characteristic Bridger animal.

\section{MIDDLE EOCENE EUROPE, ÉTAGES LUTÉTIEN SUPÉRIEUR, BARTONIEN).}

\section{BRIDGER FORMATION; OROHIPPUS AND UINTATHERIOM ZONES.}

(Figs. 1, 2, 6, Pl. I.)

HOMOTAXIS.

North America.-1, Bridger formation of western Wyoming (1,850 feet), including levels A, B, C, D, E. 2, Upper part of Huerfano formation of Colorado, 3, Lower beds, or Uintatherium zone, in Uinta and Washakie basins of northern Utah (800 feet) in part. 4, Clarno formation of Oregon, Merriam; homotaxis provisional.

Europe, provisional homotaxis.-Lower part of the Bridger approximately equivalent to Lutétien supérieur, represented by the Calcaire grossier (Paris basin), Issel, Buchsweiler, and later fissure deposits of Lissieu and Egerkingen. Upper part of the Bridger approximately equivalent to Bartonien (Calcaire de Saint Ouen, Grès de Cesséras) in part.

\section{CHIEF CHARACTERS OF THE FAUNA. ${ }^{a}$}

The whole vertebrate fauna, reptilian and mammalian, of this period is better known than that of any of the other Eocene phases. The mammalian summary is as follows:

Summary of genera.

Archaic Cretaceous mammals.......................... 32

Modernized Tertiary mammals....................... 45

A marked numerical predominance, in the ratio of 4 to 3 , of the modern over the archaic genera of mammals. A single South American mammal appears, the primitive armadillo Metacheiromys, related to the Dasypoda. Affinities with western Europe are very 
slight indeed. Independent evolution both of the surviving archaic and of the modern American lower Wasatch stock, with no evidence of fresh Eurasiatic migrations. Establishment of certain characteristically American families of mammals.

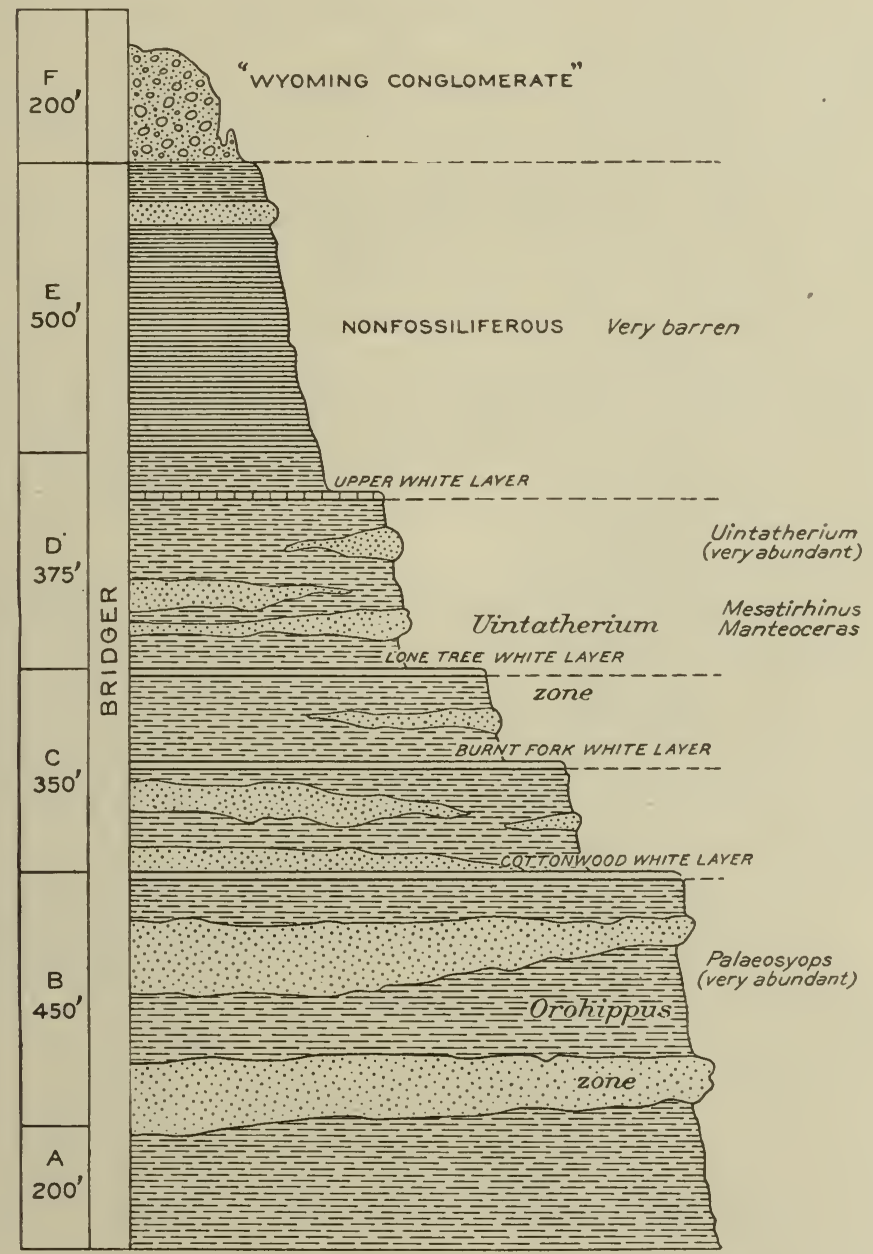

Fig. 6.-Columnar section of the Bridger formation, Henrys Fork, western Wyoming. After studies by Matthew and Granger, 1902.

Preliminary faunal divisions.-The Bridger has been separated (Matthew, Granger) into four distinct faunal levels; A-D, marked by distinct specific stages and generic stages, also by the appearance and disappearance of certain types.

1, Lower part of Bridger, levels A-B. Orohippus zone. ('haracterized by absence of Uintatherium; presence of Tillodontia, 
Trogosus (?Anchippodus ${ }^{a}$ ): Perissodactrla-Equida, Orofiplpus: Carnivora. Oödectes. Tulparus.

2, Upper part of Bridger, levels (-D. Tintatherium zone. Characterized by presence of Cintatherium: Perissodactyla-Titanotheriida, Mesatirhinus megarhinus: Tillodontia. Tillotherium: and lower beds, or Ëintatherium zone, of Uinta and Washakie basins, ?upper part of Huerfano. Colorado.

The fauna of these levels is very fully known and the levels are sharply distinguishable.

The archaic fauna ${ }^{b}$ includes mostly mammals of larger size. As in the Wind River, the Carnirora-Creodonta include 3 familiesOxyænidæ. Hrænodontidæ, and Mesonrchidæ-predaceous types rapidly increasing in size and power. Aberrant Tillodontia, 2 genera (Trogosus. Tillotherium), their last appearance. EdentataTænioclonta, 1 genus (Stylinodon), scarce animals, also their last appearance. Of Ungulata-Amblrpoda, the Uintatheriidæ or giant Dinocerata suddenly appear in the upper Bridger, possibly from the Great Plains Region.

The modern fauna includes mammals of small and intermediate size for the most part. The pro-Carnirora, Miacidæ, rapidly multiply and dirersify into $S$ genera. 20 species, analogous to the modern Canida in tooth structure, and probably drive out the smaller (arnirora-C'reodonta. Primates, 2-3 families, (a) Notharctidæ, (b) Anaptomorphidæ. (c) ?Microsyopidæ. Rodentia more numerous and diversified: the family relationships are uncertain, but inclucle (a) with sciuroid teeth, 2 genera; (b) with arctomroid teeth, 3 genera. Insectirora more dirersified, 4-6 families, including animals analogous to if not actually related to Erinaceidæ. Talpidæ, Soricidæ, Centetidæ, also the aberrant Pantolestidx, ?Hropsodontidæ, and !Leptictida. Related to the Edentata-Dastpoda. Metachiromys, 2 species. Ungulata-Perissodactrla flourishing. 5 families. namely: (a) Equidæ numerous, 9 species: (b) Lophiodontidæ, 3 genera: (c) Tapiridæ, 1 genus; $(d)$ Titanotheriidæ, 4 genera: first appearance of the $(\epsilon)$ Rhinocerotoidea-Hrracodontidæ. 3 genera. UngulataArtiodactyla still of small size, but dirersified into 7 genera, including primitive Selenodonta and Bunodonta.

\footnotetext{
a 1 nchippodus Leids is typically from New Jerser, Shark River. Monmouth Count!. See Proc. Acad. Nat. Sci. Philadelphia. October. 1vis, p 220.

$b$ see Appen dix. p. 91.

c Matthew observes. als to the affinities of these animals: "Ther do not make any approach to the modern Canidæ except for the dentition, which shows three groups-virerroid. crnoid. (erctoleptoid. The skeleton structure raries from cercoleptoid to rivertoid. The skull structure in the riverroid group is much more musteloid."
} 
MIIDLE TO UPPER EOCENE (EUROPE, E'TAGE BARTONIEN).

\section{LATER EOCENE DEPOSITS OF WASHAKIE BASIN; UINTATHERIUM AND EOBA- SILEUS ZONES.}

(Figs. 1, 2, 7; Pl, I.)

\section{HOMOTAXIS.}

North America.-1, Uintatherium zone, equivalent to the upper part of the Bridger formation and to the Uintatherium zone of Uinta Basin. 2, Eobasileus zone, equivalent to the Eobasileus zone of Uinta Basin. ? 3, Deposits on Sage Creek, Montana.

Europe.-Bartonien of France.

\section{HISTORY.}

The Washakie Basin is a distinct area, with deposits mainly of volcanic ash, in which Hayden (1867-1869) first used Washakie as a group name comprising the lower and middle Eocene section. Subsequently he inclined to the belief $a$ " that the upper series is either an extension eastward of the Bridger group or synchronous with it." It was similarly referred to by King as the Bridger group of the Washakie Basin. ${ }^{b}$ This upper series has sometimes been referred to in paleontologic literature as the "Washakie formation."

\section{FAUNA. ${ }^{c}$}

The mammalian fauna of this

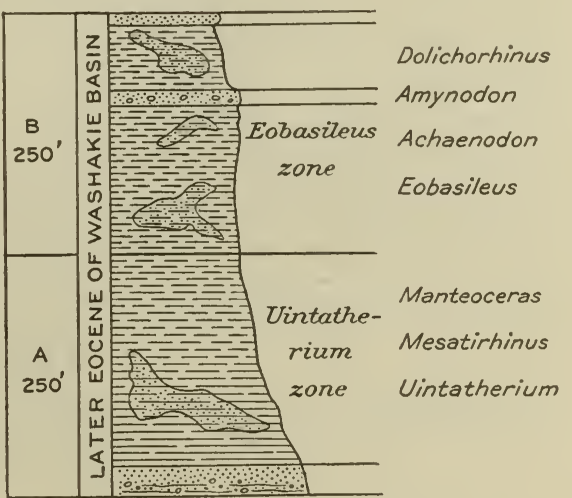

FIG. 7.-Preliminary columnar section of the later Eocene deposits of Washakie Basin, Wyoming. The upper or Eobasileus zone is now (1908) determined as thicker than the lower division.

stage, which has long been recognized (Osborn ${ }^{d} 1881$ ) as in general intermediate between the Bridger and the Uinta, is sparsely known. The American Museum expedition (Osborn, Granger) of 1906 very precisely fixed its age as overlapping the summit of the Bridger and the Uintatherium and Eobasileus zones of the Uinta Basin.

Faunal divisions.-(A) Uintatherium zone. Brown beds (250 feet) containing Uintatherium. Among Perissodactyla, Mesatirhinus mega-

$a$ Prel. Rept. U. S. Geol. Survey Terr., 1871, p. 73.

$b$ King, Clarence, U. S. Geol. Explor. 40th Par., Systematic geology, 1878, p. 396.

$c$ See Appendix, p. 91.

d A memoir upon Loxolophodon and L'intatherium: Contr. E. M. Mus. Geol. Archæol. Princeton, vol. 1 , No. 1, 1881, pp. 1-14.

McMaster, John Bach, Stratigraphical report upon the Bridger beds in the Washakie Basin, Wyoming Territory, accompanied by profiles of three sections, in Oshorn, II. F., A memoir, etc., as above. 
rhinus and Manteoceras indicate equiralence to upper Bridger (C-D). (B) Eobasileus zone. Gray and green beds (250 feet), Harstack Mountain, containing Eobasileusa (Loxolophodon); PerissodactylaAmynodontidæ; Titanotheriidæ, Dotichorhinus cornutus; Artiodactrla-Elotheriidæ.

The lower (A) brown beds are very extensively distributed and contain manr of the same species as the upper Bridger (C-D). The upper (B) gray and green beds, probably composed largely of rolcanic ash, are chiefly restricted to the great butte known as Harstack Mountain and its outlring badlands; the fauna is largely new and marks a very distinct progressive stage.

The new fauna of the Eobasileus zone.-The archaic fauna is distinguished br the final evolution of the Ungulata-Amblypoda into large. specialized Dinocerata. Carnivora-Creodonta certainly include Oxyænidæ and Mesonychidæ; the Hyænodontidæ are represented by Sinopa.

In regard to the modern fauna the most signal fact is the first appearance among the Perissodactrla-Rhinocerotoidea of the new family (a) Amrnodontidæ. The (b) Hrracodontidæ continue from the Bridger; among (c) Titanotheriidæ, Palæosyops disappears: (d) Lophiodontidæ-Helaletinæ, (e) Tapiridæ, and $(f)$ Equidæ persist. Artiodactrla are small but more diversified. Rodentia-Ischrromyidæ. ProCarnivora-Aiacidæ. Large elotheres, Achænodon, occur.

LPPER EOCENE (EUROPE, ÉTAGES BARTONIEN IN PART, LUDIEN (LIGURIEN) IN PART).

\section{LATER EOCENE DEPOSITS OF UINTA BASIN; UINTATHERIUM, EOBASILEUS, AND DIPLACODON ZONES.}

(Fig:. 1. 2. 8; Pl. I.)

\section{HOMOTAXIS.}

North America.-1, Lower $S 00$ feet, Cintatherium zone, provisionally equivalent to upper part of the Bridger formation and equiralent beds in Washakie Basin. 2, Middle 350 feet, Eobasileus zone, equivalent to upper zone of Washakie Basin. 3, Upper 600 feet, Diplacodon zone; equals Uinta formation ("true Uinta"), $b$ approaching if not equiralent to the lowermost levels of the White River Oligocene, i. e., lower Titanotherium zone or Chadron formation.

Europe--Homotaxis is now very difficult owing to the absolute dissimilarity of the European and North American faunæ in these

a The name Loxolophodon, commonly applied by Cope and others to the Dinocerata of this stage, is preoceupied for a Wasatch coryphodont, Loxolophodon semicinctu-s Cope. Tinoceras Marsh is equally inapplicable hecause first applied to a Bridger uintathere.

$b$ The Uinta formation as first noticed by Marsh (Introduction and succession of rertebrate life in America: Am. Jour. Sci., 3d ser., rol. 14, 15\%, p. 33i) included only the highest Eocene deposits, Diplucodon zone (horizon C, the "true or upper Uinta" of King and other writers), to which beds the name is here restricted. 
stages; the climax of separation between the North American and western European faunæ is reached at this stage.

\section{FAUNA. ${ }^{a}$}

It is very important to note, as to the possible lower Oligocene age of the Uinta formation (Diplacodon zone): (1) That in the Bartonien of France, which is reckoned as upper Eocene, but not the highest stage, there appear the families Artiodactyla-Anthracotheriidæ and

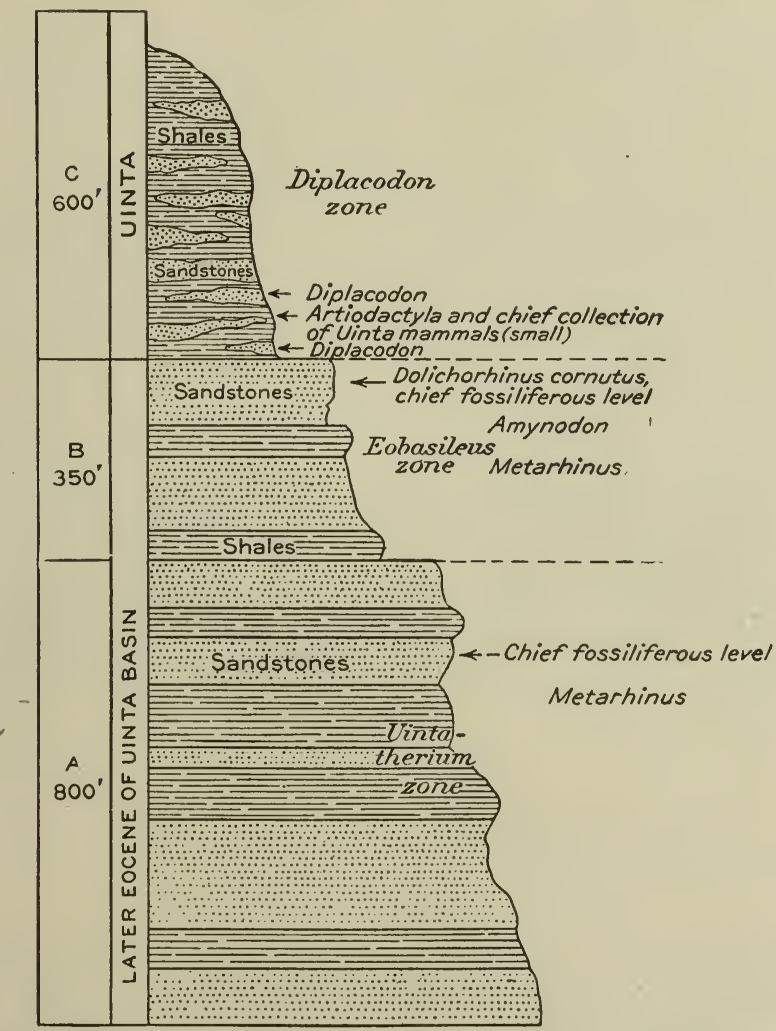

Fic. 8.-Columnar section of the Uinta formation, northern Utah. In A and B the diagram does not properly represent the irregular nature of the so-called sandstones and clays, which are probably in part coarser and finer volcanic-dust deposits. Modified from notes by O. A. Peterson, 1894. Faunistic studies of Osborn.

Perissodactyla-Chalicotheriidæ; (2) that in the Ludien, which is reckoned as uppermost Eocene, or the highest stage, there appear the families Marsupialia-Didelphyidæ and Rodentia-Sciuridæ; (3) that none of these four families are known to occur in deposits older than the lower Oligocene Plains formation of North America. We are therefore not justified, from our present knowledge, in transferring the Uinta formation (Diplacodon zone) to the lower Oligocene, as some authors (Scott) propose. 
Faunistic se paration from uestern Elorope in the upper Eacene.

\begin{tabular}{|c|c|c|c|c|}
\hline & onder. & $\begin{array}{l}\text { Families } \\
\text { Ifeculiar to } \\
\text { Europe. }\end{array}$ & $\begin{array}{l}\text { Families } \\
\text { common } \\
\text { to western } \\
\text { Europe } \\
\text { and Nort } \\
\text { America. }\end{array}$ & $\begin{array}{l}\text { Families } \\
\text { peculiar to } \\
\text { North } \\
\text { America. }\end{array}$ \\
\hline \multirow[t]{2}{*}{ 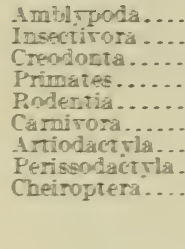 } & & $\begin{array}{l}3 \\
1 \\
0 \\
6 \\
1 \\
1\end{array}$ & 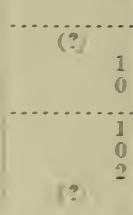 & (?) \\
\hline & & 11 & 4 & 13 \\
\hline
\end{tabular}

Thus in the later Eocene of the Mountain Region (Tintatherium, Eobasiteus, and Diplacodon zones) there are only 4 or 5 families in common with Europe out of a total of 28 to 30 , whereas in the succeeding Oligocene Mountain and Plains regions (see p. 59) there are 21 families in common with Europe out of a total of 45 .

The entire Uinta Basin deposition, as first fully explored br the American Museum expedition under Peterson, ${ }^{a}$ overlaps in time both the upper Bridger and the entire " Washakie" deposition: thus it begins (Osborn) contemporaneously with the uppermost portion of the Bridger. is equiralent to the entire "Washakie," and then continues after the close of the "Washakie" into the Linta (Diplacodon zone, "true or upper Uinta"). ${ }^{b}$ Its sparsely known mammalian fauna ${ }^{c}$ is as follows:

\section{Summary of genera.}

Archaic Cretacerus mammals.......................... G

Modern or Tertiary mammals.........................

The term Uinta formation (Marsh and King) is confined to the upper beds, or Diplacorlon zone ("true Uinta").

PROVISIONAL FACYAL LEVELS.

C. Linta formation, 600 feet. Diplacodon zone. Distinguished by absence of Dinocerata: presence of Canidæ.

B. Middle beds of Uinta Basin, later Eocene, 350 feet. Eobasileus zone. Contains among Amblrpoda-Dinocerata, Eobasiteus (generic

a Gsiom. H F.. Fossil mammals of the Cinta Basin, etc.: Bull. Am. Mus. Nat. Hist., rol. T 1595, pp. $71-105$.

"This "true tinta" fauna was that which was first determined and described br Marsh in 15:0. The underlying Cintatherium and Eobarileus faunce were first discovered by Peterson in 1 wy and descriled by the writer.

c Scott. W. B.. and Oshorn. H. F., The Mammalia of the Linta formation: Trans, Am. Philos. Soc., n. s., rol. $16,15 \%$, pp. $4 ; 1-5 ; 2$. 
reference uncertain); among Perissodactyla-'Titanotheriidæ, Dotichorhinus cornutus. ('reodonta-Mesonychicla (last appearance). Closely equivalent to upper part of "Washakie" (B).

A. Lower beds of Uinta Basin, later Eocene, 800 feet, brown beds. ? Tintatherium zone, approximately equivalent to upper part of the Bridger (C-D) and to corresponding beds in Washakie Basin (A).

Of archaic mammals the Carnivora-Creodonta include 2 families, Mesonychidæ (last appearance) and Oxyænidæ (last appearance); the Hyænodontidæ, if existent, have not been discovered. The Eobasileus zone contains the last of the Amblypoda-Uintatheriidæ. Of modern mammals (Uinta) the Primates are little known as yet. Among Rodentia 2 families, (a) Ischyromyidæ (Paramys, Pseudotomus), (b) Heteromyidæ (Protoptychus). Among Pro-Carnivora, Miacidæ, also true Carnivora ${ }^{a}$ (Cynodictis). Of Ungulata-Perissodactyla, 6 families: (a) Titanotheriidæ, horned animals of much greater size, especially increasing after the extinction of the huge Dinocerata, (b) Equidæ, (c) Lophiodontidæ (still to be discorered), (d) Tapiridæ, (e) Hyracodontidæ, (f) Amynodontidæ. No true Rhinocerotidæ. Ungulata-Artiodactyla now assume the fire divisions or families which are found in the American Oligocene, namely: (a) Elotheriidæ-Achænodontinæ, mammals of large size; (b) Homacodontidæ (Dichobunidæ ?); (c) Oreodontidæ, North America only; (d) Hypertragulidæ, North America only; (e) Camelidæ, the-first definite recognition of this family, North America exclusively until the Pliocene. The Uinta selenodonts ${ }^{b}$ are all brachyodont and much alike in dentition; they are much less abundant than in the lower Oligocene.

\section{OLIGOCENE.}

\section{FOURTH FAUNAL PHASE.}

Second modernization-First knowledge of the Great Plains faunaAbsence of all archaic mammals except Hyænodontidæ-Reestablishment of faunal resemblance with western Europe, followed by a long period of independent evolution and partial extinction of the same fauna to the close of the lower Miocene.

Environment; dry-land conditions in the Great Plains.-In addition to the geologic and faunistic evidence above cited we find collateral evidence from herpetology. The Testudinata, as analyzed by Dr. O.P. Hay, ${ }^{c}$ furnish important proofs of prevailing dry-land conditions

a A rather arbitrary distinction, founded on the union of the scapholunar bones, which first occurs in certain Bridger species of the Miacidæ; the union is exceptional in the Bridger, presumably common in the Cinta, and universal in the White River. More essential distinctions are the small size of the brain and the absence of tympanic bullæ.

$b$ Scott, W. B., The selenodont artiodactyls of the Uinta Eocene: Trans. Wagner Free Inst. Sci., Philadelphia, vol. 6, 1899, pp. ix-xiii, 1-121.

$c$ In his monograph on the fossil turtles of North America, published by the Carnegie Institution. 
in the Great Plains. How long previously these conditions had set in it is impossible to sar. In the entire Oligocene and Miocene beds thus far only 6 species of water-living turtles have been described or recorded, and these are probably from river-channel sandstones, as compared with a rery much larger number of land-living tortoises.

The details are as follows: (1) In the White River group (lower Oligocene) there occur $S$ species of the Testudinidr. including one of the land tortoise Stylemys: one species of Testudo, T. brontops Marsh, belongs to the Chadron formation, or Titanotherium zone: all of these are land tortoises, mostly found in Colorado. Of water-living forms the White River group of South Dakota has furnished one species of the Emydidæ, river turtles, and one of the Dermatemydidæ. a small family related to the Chelydridæ and now confined to Central America. (2) In the middle part of the John Day formation (upper Oligocene, Mountain Region) there are 3 species of Stylemys, land tortoises. In the Deep River sequence (middle Miocene; Mountain Region) occurs a single species of Testudo: from the Mascall formation of Oregon there is known a species of Clemmys, a genus now liring in America and Asia. From the deposits on Pawnee Creek, Colorado, come 2 large species of Testudo. (4) The “Loup Fork beds" (upper Miocene, Plains Region) furnish $T$ species of Testudo, approaching in size the great tortoises of the Galapagos Islands. (5) From the Rattlesnake formation of Oregon (Pliocene) occurs a species of Clemmys, a land tortoise.

Modernization in North America.-A second American modernization, as remarkable as the first or Wasatch modernization, is shown by the first appearance of 16 families of mammals which hare not as ret been certainly recognized in the Mountain Eocene basins, namely, 6 existing families of Rodentia, 4 existing families of Carnivora, 4 existing families of Insectirora, 1 existing family of Perissodactyla, 1 now extinct European family of Artiodactyla.

Modernization in Europe.-A rery similar modernization occurred in western Europe. ${ }^{a}$ In the Ludien (=lower Oligocene, Lapparent, uppermost Eocene, Depéret), Sannoisien, and Stampien (=lower Oligocene) 17 modern or still existing families which hare not been found in earlier geologic stages appear for the first time. Of these new families, 6 appeared simultaneously in North America.

- This generalization is chiefly based upon the faunal lists of Deperet (see footnote, p. 9). 
Faunistic reunion with western Europe in the Oligocene.

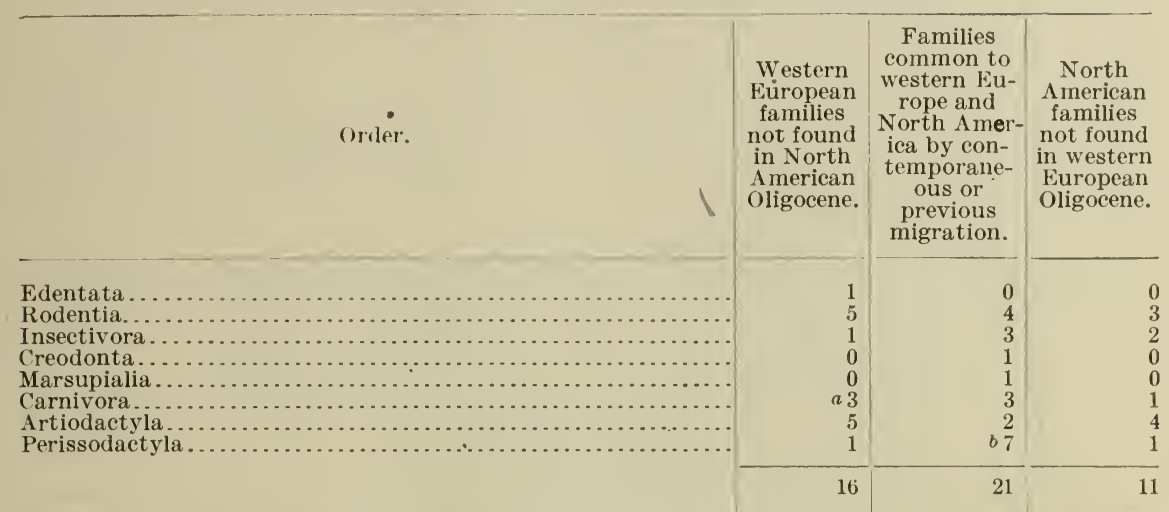

$a$ Subfamily.

$b$ The Titanotheriidæ found in central Europe are included in this number. Dr. Hl. G. Stehlin (letter, April 15, 1907?) regards the geologic level of these animals as Oligocene. They closely resemble certain of our titanotheres.

Thus (1) the faunal community with western Europe becomes much closer than in the upper Eocene (see p. 56); (2) it is important to note that many American lower Oligocene types are represented by more primitive forms of European upper Eocene types and partly of north African types, namely, Hyænodon, Hyopotamus, Elotherium, and Suoidea-Dicotylidæ; (3) the strongest community is among the Perissodactyla, with 7 families out of 9 in common; (4) the least community is among the Artiodactyla, with only 2 families out of 11 in common.

As above noted, this momentous faunal change in North America may be more apparent than real, because attributable to various causes: (1) Partly to the fact that this is our first glimpse of the western portion of the Great Plains fauna; (2) partly to fresh migration from the northerly or North American-Eurasiatic region. The apparent sharp distinctions of this phase from the Uinta faunal phase will probably be partly lessened when a fuller knowledge of the Uinta mammals shall have been gained.

There are many distinctive characters of this North American faunistic stage, as follows: (1) First appearance of MarsupialiaDidelphyidæ and of Rhinocerotidæ-Diceratheriinæ; (2) sudden disappearance of all Primates, which do not again appear in North America; (3) continued evolution of certain of the North American families of mammals derived from the first modernization, 4-toed horses replaced by 3 -toed horses, advanced evolution of American Eocene Rodentia (Paramys, Sciuravus), appearance of Eurasiatic Rodentia; (4) extinction of other modernized North American families, including especially 4 families of Perissodactyla, also, InsectivoraHyopsodontidæ; (5) migration, probably from Eurasia, of some new 
families-Perissodactyla-Chalicotheriidae, Artiodactyla-Anthracotheriidæ, Suoidea, Creodonta-Hyænodontidx; (6) first appearance of Carnivora-Mustelidæ, probably from the northern continental mass, also Canidæ and Felidæ-Machærodontinæ; (7) probable migration to Eurasia of some of the North American families, PerissodactylaTapiridæ, Amynodontidæ.

LOWER OLIGOCENE, WHITE RIVER GROUP OF HAYDEN (EUROPE, ÉTAGE SANNOISIEN [TONGRIEN INFÉRIEUR]).

\section{CHADRON FORMATION ; TITANOTHERIUM ZONE.}

(Figs. 1, 9, 10; Pls. I-III.)

\section{HOMOTAXIS AND SYNONYMY.}

North America.-1, Horizon A of Hayden and Leidy; lower part of the White River group; 2, Chadron formation, 200 feet, of Darton; 3, "Titanotherium beds" a of Leidy and Hayden, South Dakota; 4, "Horsetail Creek beds" of Matthew, ${ }^{b}$ northeastern Colorado and western Nebraska; 5, Monument Creek formation (upper part) of Darton; 6, White River deposits along Pipestone Creek, Montana (Douglass, 1902); and 7, White River deposits along Swift Current Creek, Cypress Hills, British Columbia, ${ }^{c}$ etc.

Europe, provisional homotaxis.-Ludien, in part; Sannoisien (Tongrien inférieur); Stampien (Tongrien supérieur).

\section{FAUNA. ${ }^{d}$}

It is important to note again that four or more of the newly appearing families of mammals are represented in the upper Eocene of Europe. Our knowledge of the animals of this stage, which is at present considered lower Oligocene, is still rather limited except as to the Titanotheriidæ, which are very abundant and characteristic. In the White River beds at Pipestone Springs, Montana, ${ }^{e}$ were first discovered (Douglass ${ }^{f}$ ) the animals of smaller size or microfauna. In all the other deposits chiefly the larger animals are known.

$a$ Hatcher, J. B., The Titanotherium beds: Am. Naturalist, Mar. 1, 1893, pp. 204-221.

$b$ Matthew, W. D., Stratigraphy of the White River and Loup Fork formations: Bull. Am. Mus. Nat. Hist., vol.1, pt. 7, 1901, pp. 355-374.

c Cope, E. D., The White River beds of Swift Current River, Northwest Territory (Geol. Oligocene White River): Am. Naturalist, Feb., 1885. Also Ann. Rept. Geol. and Nat. Hist. Survey Canada, vol. 1, 1885 (1886), appendix to Article C, pp. 79-85.

$d$ See Appendix, p. 91 .

Scott, W. B., and Osborn, H. F., Preliminary account of the fossil mammals from the White River formation contained in the Museum of Comparative Zoology: Bull. Mus. Comp. Zool. Harvard Coll., vol. 13, 1887, pp. 151-171.

Osborn, H. F., and Wortman, J. L., Fossil mammals of the lower Miocene White River beds, coll. 1892: Bull. Am. Mus. Nat. Hist., vol. 6, 1894, pp. 199-228.

e Matthew, W. D., The fauna of the Titanotherium beds of Pipestone Springs, Montana: Bull. Am. Mus. Nat. Hist., vol. 19, 1903, pp. 197-226.

$f$ Douglass, Earl, New vertebrates from the Montana Tertiary: Ann. Carnegie Mus., vol.2, No.2, 1903, pp. 145-200. (White River stratigraphy.) 


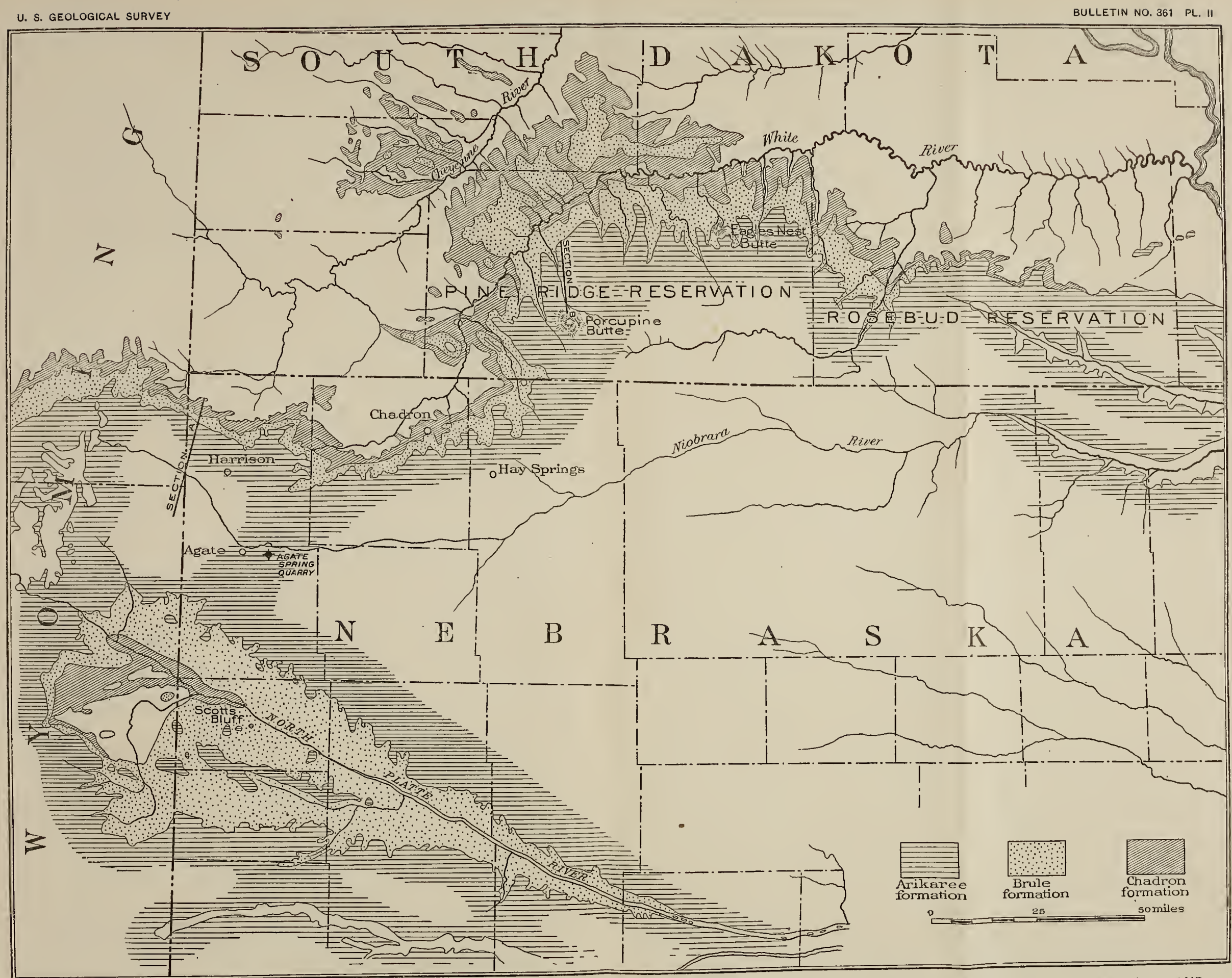

OLIGOCENE (CHADRON, BRULE) AND MIOCENE (ARIKAREE, HARRISON, ROSEBUD) EXPOSURES IN SOUTH DAKOTA, NORTHWESTERN NEBRASKA, AND EASTERN WYOMING.

After Darton's survey, 1905, modified by observations of Matthew and Thomson (1906-7). For section A see fig. 14i for section B see fig. 12 

The archaic mammals are now represented only by the true Hyænodontinæ, which are probably of European and African origin. Among Marsupialia, Didelphyidx are somewhat doubfully recorded in this stage.

Of the modernized mammals, among Rodentia (a) Ischyromyidx, represented by Ischyromys; Paramys disappears or gives rise to Sciurus; and there first appear the modern $(b)$ Leporidæ, $(c)$ Castoridæ, (d) Sciuridæ, and (e) Geomyidæ. Of Insectivora the Leptictidæ continue, as well as animals analogous in dentition to Centetes and Solenodon. The Carnivora are thoroughly modernized by the appearance of true Canidæ (Cynodictis, Daphænus), Mustelidæ, and Felidæ (Machærodontinæ). Eight families are known of Ungulata-Perissodactyla, including 6 Eocene families which survive from the upper Eocene, namely, (a) Equidæ, (b) Tapiridæ, (c) Amynodontidæ, (d) Hyracodontidæ, (e) Lophiodontidæ, (f) Titanotheriidæ, ${ }^{a}$ which reach the climax of their evolution and suddenly disappear, $(g)$ the aberrant Perissodactyla-Chalicotheriidæ are first positively recognized, $(h)$ the Rhinocerotidx, ancestors of Diceratherium, and another subfamily (?Aceratheriinæ) also first appear. Of Artiodactyla 6 families occur, as follows: Three previously known Eocene families, (a) Oreodontidæ, (b) Camelidx, and (c) Hypertragulidæ, continue; $(d)$ the Dicotylidæ first appear, either of American origin from the Great Plains or of Eurasiatic origin as a side branch of the Suoidea; (e) the Anthracotheriidx also first appear, probably by migration from Europe, and are represented by Hyopotamus in the Chadron formation; $(f)$ the bunodont Achænodontinæ of the upper zones in the Washakie and Uinta basins are succeeded or replaced by the Elotheriinæ or Entelodontinæ closely allied to the European Entelodon.

Monument Creek formation.-The following description of this formation is taken from a paper by Darton published in $1906:^{b}$

On the high divide between the Platte and Arkansas drainage basins, at the foot of the Rocky Mountains, there is an extensive deposit of conglomerates, sand, sandstone, gravel, and clay, known as the Monument Creek formation. It lies on the Laramie formation to the east and the Arapahoe formation to the west, and at Palmer Lake it abuts against the granite at the foot of the mountain. There are two members, a lower one of sands and clays and an upper one of conglomerate and sandstone. The latter caps numerous buttes and plateaus in the high region west and north of Calhan and north of Monument.

Fossil bones of Titanotherium have been discovered by the writerc and Mr. C. A. Fisher in the upper member in the region north of Calhan and southwest of Elizabeth, which indicate that this portion of the formation is of Oligocene age. The lower member may be Oligocene, or perhaps Wasatch or Bridger, in age.

a Osborn, H. F., The four phyla of Oligocene titanotheres: Bull. Am. Mus. Nat. Hist., vol. 16, 1902, pp. 91-109.

$b$ Darton, N. H., Geology and underground waters of the Arkansas Valley in eastern Colorudo: Prof. Paper U. S. Geol. Survey No. 52, 1906.

c Darton, N. H., Age of Mlonument Creek formation: Am. Jour. Sci., 4th ser. vol. 20, 1905, pp. 178-180. 


\section{MIDDLE OLIGOCENE (EUROPE, ÉTAGE STAMPIEN [TONGRIEN SUPÉRIEUR]).}

\section{LOWER PART OF BRULE CLAY (DARTON); OREODON ZONE AND "METAMY- NODON SANDSTONES."}

(Figs. 1, 9, 10; Pls. I-III.)

\section{HOMOTAXIS AND SYNONYMY.}

North America.-1, Horizons B and C of Hayden and Leidy. 2, Oreodon zone of Leidy. 3, Lower Brule clay of Darton. ${ }^{a}$ 4, "Metamynodon sandstones" of Wortman. ${ }^{b}$ (1-4 all of South Dakota.) 5, "Cedar Creek beds" of Matthew, ${ }^{c}$ northeastern Colorado. 6, Widespread similar exposures in southeastern Wyoming, South Dakota, and northwestern Nebraska. 7 , Scattered exposures in western Montana.

Europe--Approximate homotaxis with the Stampien or Oligocène moyen of Europe is indicated by similar stages in the evolution of Artiodactyla-Anthracotheriidæ (Hyopotamus), of Perissodactyla-

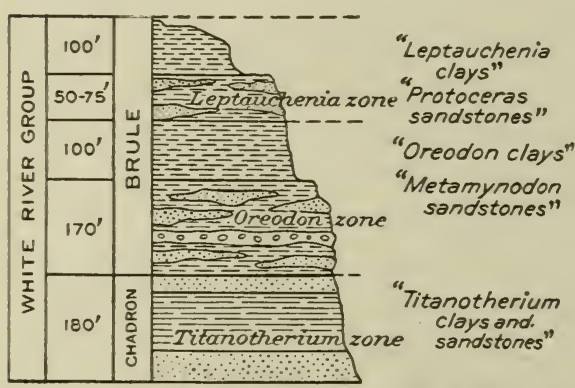

FIG. 9.-Diagrammatic section of the White River group, South Dakota. (Cf. Pl. II.) Chiefly after Wortman. 1892 Amrnodontidæ (e. g., Metamynodon, Cadurcotherium), of Tapiridæ, of Rhinocerotidæ, and of Chalicotheriidæ. Also by the apparent disappearance in both countries of PerissodactylaAmynodontidæe and CreodontaHyænodontidæ in the upper Oreodon zone.

\section{FAUNA. ${ }^{d}$}

The rich mammalian fauna (more than 45 species being known in the big badlands of South Dakota alone) is distinguished negatively by the absence of Titanotherium and positively by the presence of abundant oreodonts.

The important distinction was first made by Matthew ${ }^{e}$ that the Brule clay, or Oreodon zone, of fine, still-water or eolian composition,

a Darton, N H., Preliminary report on the geolog! and underground-water resources of the central Great Plains: Prof Paper C. S Geol Survey No. 32, 1905.

$b$ Wortman, J L, On the divisions of the White River or lower Miocene of Dakota: Bull. Am. Mus. Nat. Hist., rol. 5, 1893. pp. 95-105.

Osborn, H. F and Wortman, J - L, Fossil mammals of the lower Miocene White River beds: Bull. Am. Mus. Nat. Hist, rol 6, 1894, p. 200 (section).

c Matthew, W. D., Fossil mammals of the Tertiary of northeastern Colorado: Mem Am. Mus Nat. Hist., vol. 1, pt. 7,1901 , p. $35 \tilde{i}$.

$d$ See Appendix, p. 91.

e Is the White River Tertiary an eolian formation? Am. Naturalist, vol. 33, 1899, p. 404. 
contains chiefly the Plains fauna, while the irregular "Metamynodon sandstones," traversing the lower Oreodon zone and of river-channel origin, contain chiefly the forest and aquatic fauna. (See fig. 9.) Forested, fluviatile, and plains or open-country conditions are indicated by the mingling of many mammals of modern type in the respective fluviatile and plains deposits.

Among Insectivora the first North American erinaceid (Proterix) appears., Rodentia include 16 genera; we note the last appearance of the Eocene Ischyromyidæ and the first appearance of the modern Muridæ. Of Carnivora-Canidæ, Cynodictis and Daphænus continue from the underlying Titanotherium zone; of Felidæ, 3 genera of Machærodontinæ; of Mustelidæ, Bunælurus. The Perissodactyla are reduced to 7 families: (a) Equidæ (species numerous and diversified); (b) Tapiridæ; (c) Lophiodontidæ (their last appearance); (d) Amynodontidæ (their last appearance); (e) Rhinocerotidæ (including 2 genera); (f) Hyracodontidæ. Artiodactyla include 8 families: (a) Leptochœridæ; (b) Elotheriidæ; (c) Dicotylidæ; (d) Agriochœridæ; (e) Oreodontidæ; $(f)$ Camelidæ; (g) Anthracotheriidæ; (h) Hypertragulidæ.

UPPER OLIGOCENE, FIRST PHASE.

10. UPPER PART OF BRULE CLAY; LEPTAUCHENIA ZONE AND "PROTOCERAS SANDSTONES."

(Figs. 1, 9, 10; Pls. I-III.)

HOMOTAXIS.

North America.-1, Horizon C of the Hayden and Leidy section. 2, Upper part of White River formation of South Dakota. 3, Brule clay (upper part) of Darton, ${ }^{a} 1897$. Leptauchenia zone of Wortman. The "Protoceras sandstones" contain the forest and fluviatile fauna; the clays of the Leptauchenia zone contain the plains fauna. 4, Lower part of "Martin Canyon beds" of Matthew, ${ }^{b}$ northeastern Colorado. 5, Deposits at White Buttes, North Dakota.

\section{FAUNA. ${ }^{c}$}

Characterized negatively, so far as we know, by disappearance or absence of the Hyænodontidæ, the last of the archaic Mammalia; by extinction or absence of the Eocene Rodentia-Ischyromyidæ; by extinction of 2 families of Perissodactyla, Lophiodontidæ and Amynodontidæ.

$a$ Prof. Paper U. S. Geol. Survey No. 32, 1905.

$b$ Fossil mammals of the Tertiary of northeastern Colorado: Mem. Am. Mus. Nat. Hist., vol. 1, pt. 7, 1901, pp. 353-447.

$c$ See Appendix, p. 91. 
Among Carnivora there now appear in North America representatives of all the existing families except (1) Viverridæ and Hyænidæ, which never reached America; (2) true Felinæ, which first appear in the middle Miocene; (3) Procyonidæ, which first appear in the lower Miocene; and (4) Ursidæ, which first appear in the middle Pleistocene of North America. Among Rodentia is noted the first appearance (lower part of the John Day of Oregon) of the distinctively American Haplodontidæ; also of the Castoridæ (Steneofiber). Among Insectivora, first appearance of the Talpidæ in North America (the Eocene forms with analogous teeth may be ancestral). Among surviving Perissodactyla is noted the presence of numerous larger members of the Equidæ, Tapiridæ, and Rhinocerotidæ, the latter family including (a) members of the Diceratheriinæ with very rudimentary horns, and (b) members of the Aceratheriinx of larger size. Artiodactyla now become very distinctive: Among Oreodontidæ Leptauchenia and Eporeodon appear; among Anthracotheriidæ Hyopotamus continues; among Camelidæ Protomeryx replaces Poëbrotherium; among Hypertragulidx Protoceras (first appearance of this type) is the most distinctive form in the sandstones of South Dakota.

While the "Protoceras sandstones" and the clays of the Leptauchenia zone were being deposited in the Plains Region, there began the volcanic-ash depositions of the John Day formation in the Mountain Region of Oregon.

\section{OREGON CENOZOIC FORMATIONS.}

\section{RÉSUMÉ OF THE OREGON DEPOSITS AS A WHOLE.}

The known mammal fauna of Oregon, as determined partly by Cope and Wortman and more precisely as to levels by Merriam and Sinclair, is found on five levels, partly separated by volcanic overflows, as follows:

Rattlesnake

Mascall

Upper part of John Day

Middle (fossils numerous) and (?) lower parts of John Day
$=$ upper Miocene

$=$ middle Miocene

$=$ Transition, upper Oligocene, lower Miocene

$=$ upper Oligocene, second phase
$=$ Procamelus zone.

= Merychippus zone.

= Promerycochœrus zone.

= Diceratherium zone

JOHN DAY FORMATION.

(Figs. 1, 10, 11; Pl. I.)

Age.-The time of the beginning of the John Day deposition appears to correspond with that of the close of the Leptauchenia zone in the South Dakota region (fig. 10), namely, the upper Oligocene. 


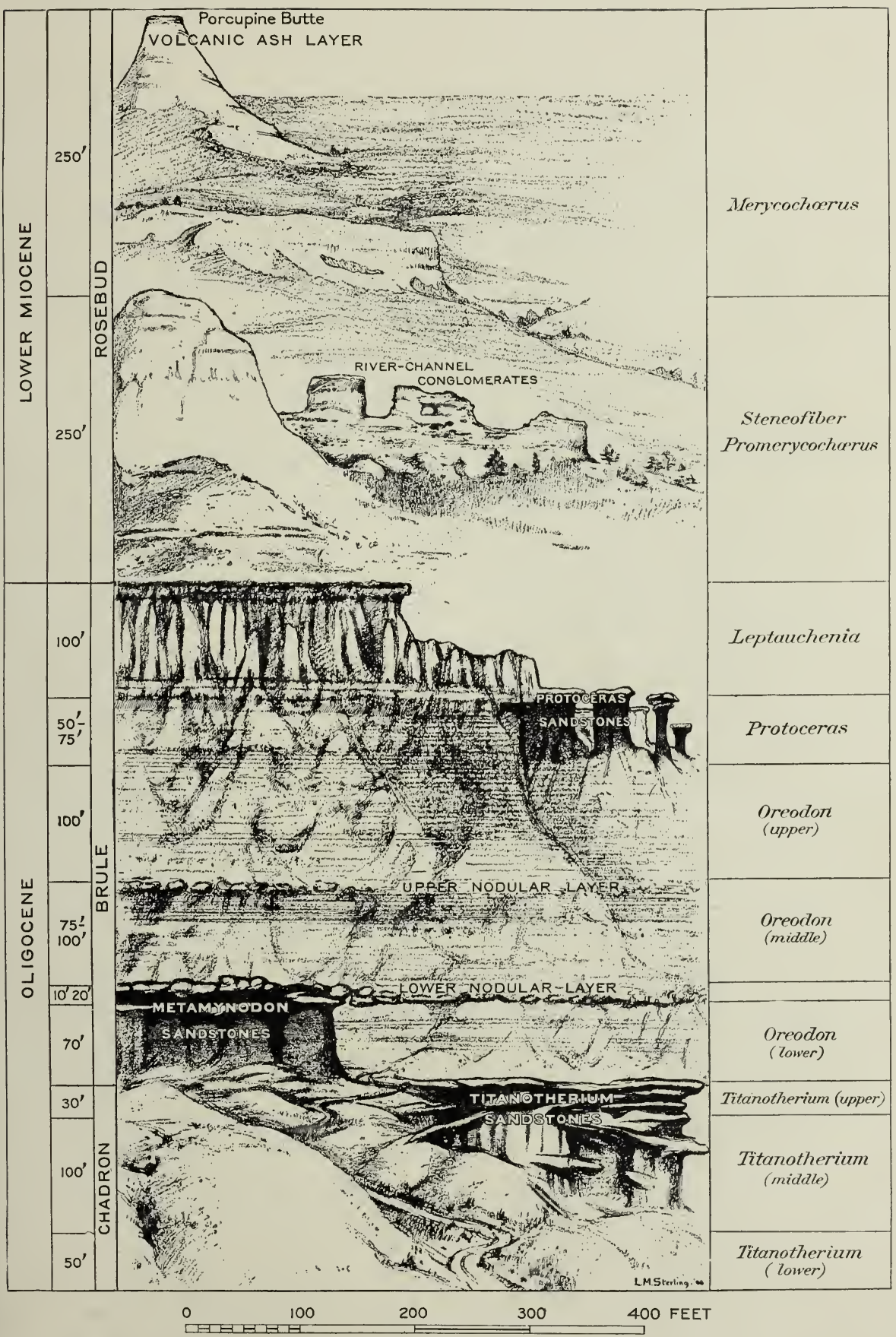

IDEALIZED BIRD'S-EYE VIEW OF THE GREAT BADLANDS OF SOUTH DAKOTA, SHOWING CHANNEL AND OVERFLOW DEPOSITS IN THE OLIGOCENE AND LOWER MIOCENE.

Looking southeast across Cheyenne and White rivers to Porcupine Butte, on Porcupine Creek, Pine Ridge Reservation. The location of the panorama is shown in PI. II, approximately on the line of section B. The ancient river-channel deposits in the successive levels are the "Titanotherium sandstones," "Mrtamymodon sandstones," and "Protoceras sandstones." River-channel conglomerates appear in the Rosebud levels also. 

OF WESTERN NORTH AMERICA.

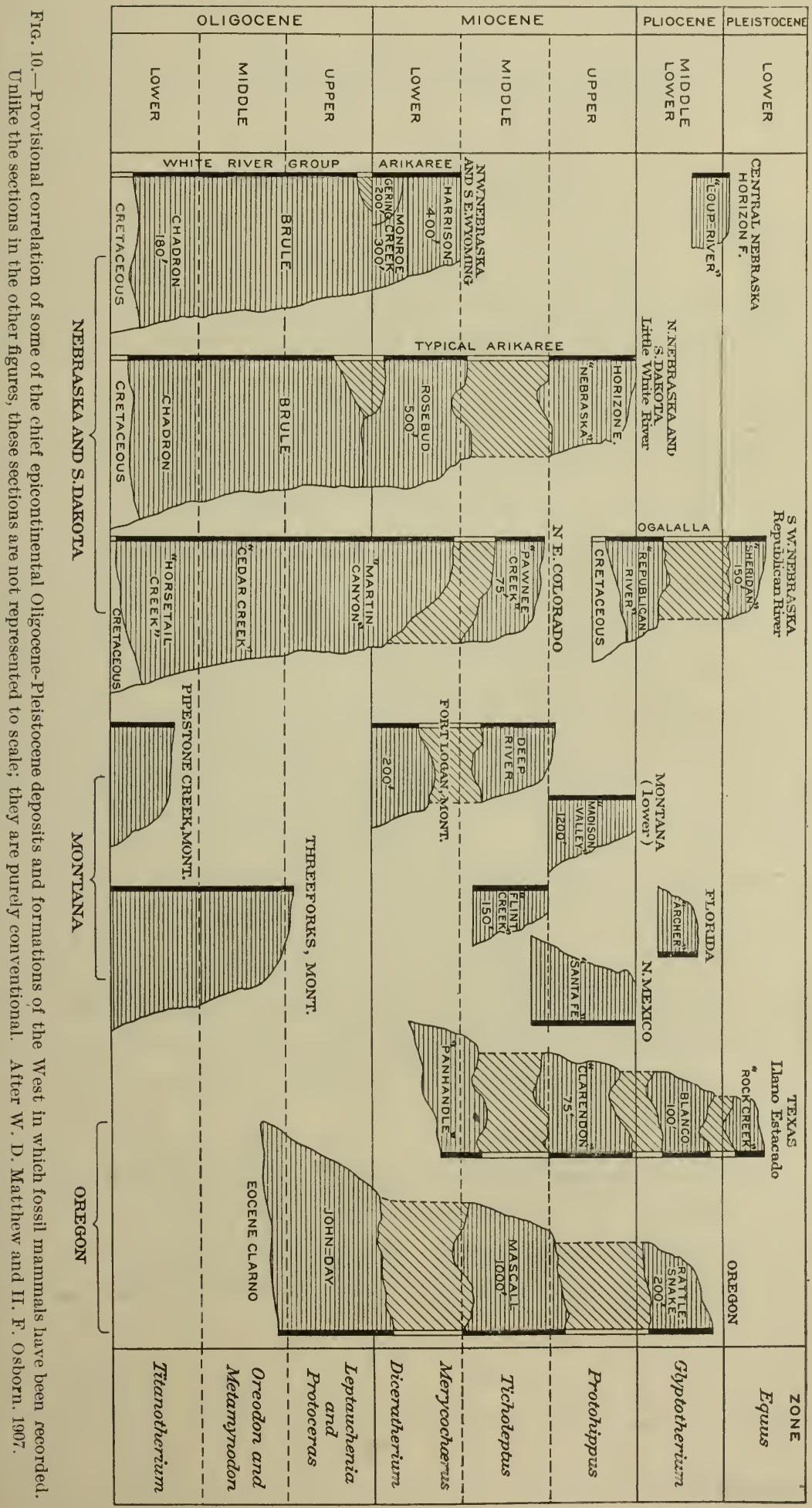

56092-Bull. 361-09-5 
Conditions of deposition.-The volcanic materials of the John Day were chiefly wind blown, as described by Merriam; ${ }^{a}$ there is little evidence of fluviatile conditions. The Mollusca are terrestrial or air breathing, with the exception of one locality which contains fluviatile Mollusca. The Testudinata, genus Stylemys, are of the Testudo, or terrestrial type; no fluviatile types have been recorded. The socalled beavers (Castoridæ) are not the true river-living beavers (Peterson).

Fauna. ${ }^{b}$ - The known fauna of the John Day formation as a whole is chiefly of open-forest and savanna-living type. We note the entire disappearance of the ancient fauna, Creodonta-Hyænodontidæ, and do not observe the introduction or invasion from Eurasia of any new families of mammals. The major part of the John Day fauna is of upper Oligocene age, but in its latest phases it is perhaps transitional to lower Miocene. The fauna is thus broadly transitional between that of the White River group and the Arikaree formation.

The more ancient Ischyromyidæ having disappeared, the modern Rodentia are represented by 6 existing families-Sciuridæ, Castoridæ, Geomyidæ, Muridæ, Leporidæ, and Haplodontidæ (Allomys, Mylagaulodon). Among the Carnivora highly varied Canidæ abound, the Felidæ are numerous but confined to the machærodont type, and there is a single member of the Mustelidæ, Oligobunis. The Perissodactyla begin to be reduced to the 3 existing families of Equidæ, Tapiridæ, and Rhinocerotidæ; the aberrant Chalicotheriidæ occur. Among Artiodactyla, the Elotheriidæ attain a great size; in the middle part of the John Day the peccary-like pigs, Dicotylidæ, are found in great numbers; a wider differentiation arises among the Oreodontidæ, but Leptauchenia does not occur here. In the upper part of the John Day the members of the Camelidæ are first recorded (Sinclair) and begin to attain considerable size; a species of Paratylopus or Miolabis occurs, resembling the species of the lower Arikaree. The lower John Day fauna is so little known that no deductions can be made from it, except that it appears to be closely related to that of the middle John Day.

The faunistic comparison of the John Day formation therefore begins with the middle John Day, which is highly fossiliferous and slightly more advanced than that of the upper portion of the Brule clay and "Protoceras sandstones," as will now be shown.

a A contribution to the geology of the John Day basin; Bull. Univ. California, Dept. Geology, vol. 2, 1901, pp. 269-314.

$b$ See Appendix, p. 91. 
UPPER OLIGOCENE, SECOND PHASE (EUROPE, ETAGE AQUITANIEN).

11. MIDDLE PART OF JOHN DAY FORMATION; DICERATHERIUM ZONE (ALSO UPPER PART OF JOHN DAY, TRANSITIONAL).

(Figs. 1, 10, 11; Pl. I).

\section{HOMOTAXIS AND SYNONYMY.}

America.-1, Middle part of the John Day formation of Oregon. ${ }^{a}$ 2, Diceratherium zone of Wortman (500 to 1,000 feet).

Europe.-Aquitanien. Homotaxis with the Aquitanien of France (typified by the St. Gérand-le-Puy, Allier) is close, as indicated by

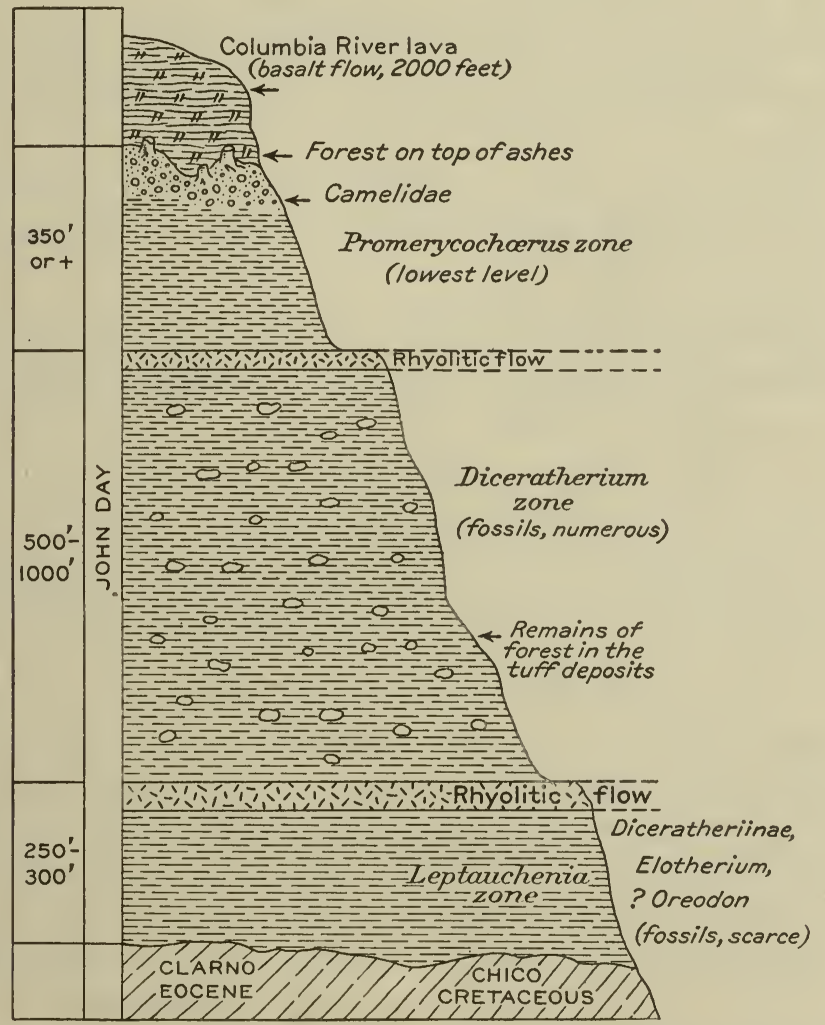

Fig. 11.-Columnar section of the John Day formation (Oregon), based on studies by Merriam and Sinclair.

similar stages in the evolution of Perissodactyla-Tapiridæ, Diceratheriinæ, Aceratheriinæ, Chalicotheriidæ, and other families.

\section{FAUNA. ${ }^{b}$}

The evolution stages in members of this typical Mountain fauna of the middle part of the John Day are in some families (e. g., Equidæ, 
Tapiridæ) similar to those of the Brule clay, in others (e. g., Rhinocerotoidea, Rodentia) more advanced than those of the upper Brule clay and "Protocercis sandstones." This more or less progressive character is illustrated as follows: Among Perissodactyla-Rhinocerotidæ Diceratherium is more advanced, with well-developed horn cores; among Tapiridæ Protapirus is similar to that in the "Protoceras sandstones;" among Equidæ browsing horses, small and similar to those of the "Protoceras sandstones." Among Artiodactyla 5 families: Elotheriidæ, Hypertragulidæ, Oreodontidæ (Eporeodon, Agriochœrus), Dicotylidæ, Camelidæ (not certainly present). Among Carnivora-Felidæ (Archælurus, Nimravus); among Canidæ Nothocyon, Temnocyon, Mesocyon, Philotrox. Among Rodentia Leporidæ (Lepus), Castoridæ (Steneofiber); also two new and peculiarly American rodent families, Geomyidæ (pocket gophers) and Haplodontidæ (sewellels, Meniscomys).

The conclusion is that the middle John Day deposition partly overlaps and is partly sequent to the deposition of the upper part of the Brule clay and the "Protoceras sandstones."

UPPER OLIGOCENE, LATEST PHASE (ELROPE, ÉTAGE AQUITANIEN).

\section{UPPER PART OF JOHN DAY FORMATION; PROMERYCOCH@RUS ZONE.}

(Figs. 1, 10, 11; Pl. I.)

\section{HOMOTAXIS.}

North America (provisional).-Great Plains: 1, Lower portion of Rosebud, of Matthew. 2, Gering, of Peterson's Running Water section. (See fig. 13.) 3, ? Gering, of Darton's Scotts Bluff section.

FACNA, ${ }^{a}$ EARLY PHASE.

The fauna of the upper part of the John Day formation is rich, but the levels have been certainly recorded only in the case of the following animals: Among Rodentia, Lepus, Entoptychus, Mylagaulodon. Among Carnivora-Canidæ, Nothocyon, Mesocyon, Temnocyon. Among Perissodactyla, (a) Equidæ, Anchitherium præstans, Mesohippus acutidens; (b) Tapiridæ, Protapirus; (c) Rhinocerotidæ, ?Diceratheriinæ, ? Aceratheriinæ. Among Artiodactyla, (a) Elotheriidæ, (b) Dicotylidæe, (c) Oreodontidæ, Promerycochœrus, 4 species, Eporeodon, (d) Hypertragulidæ, (e) Camelidæ, Paratylopus sternbergi, P. cameloides. ${ }^{b}$

TRANSITION FROM UPPER OLIGOCENE TO LOWER MIOCENE IN UPPER PARTS OF JOHN DAY, GERING, AND HARRISON AND LOWERMOST PART OF ROSEBLD.

From the preceding American Oligocene (upper part of Brule clay or Leptauchenia zone, and lower and middle parts of the John Day)

$b$ The only camels from the John Day obtained by the Lniversity of California expeditions came from the top of the formation. The matrix of the trpe of $P$. sternbergi shows that it is not from the middle John Day, as Wortman supposed (Sinclair, Norember, 1906). 
the transition beds are sharply demarcated positively (1) by the sudden appearance among Artiodactyla-Oreodontidæ of Promerycochœrus followed in higher levels by Merycochœrus and Merychyus; (2) by the survival of progressive species of Leptauchenia in the same family; (3) among Artiodactyla also, 3 families of earlier horizons apparently have become extinct, namely, Anthracotheriidæ (which also disappear in the Aquitanien of France), Leptochœridæ, and OreodontidæAgriochœrinæ.

COMPARISON WITH EUROPEAN HORIZONS OF UPPER OLIGOCENE AGE.

The upper part of the John Day formation, or Promerycochorus zone, of the Mountain region of Oregon, as well as the Gering and Monroe Creek formations of Hatcher, the Gering or lower Arikaree of Darton, the Rosebud (lower levels, see fig. 12) of Matthew, all in the Plains region of South Dakota, may be regarded as covering the transition between the Oligocene and Miocene epochs, as these divisions are employed in France. They resemble chiefly the upper Oligocene of France. (1) The upper part of the John Day of the Mountain region is somewhat older than the lower part of the Rosebud of the Plains, although both contain Promerycochœrus. (2) Recent explorations in the upper portion of the Harrison and equivalent formations ${ }^{a}$ reveal a fauna which partly resembles that of the upper Oligocene of France (an Oligocene character is given by the survival of Elotherium); at the same time, it contains a primitive Amphicyon, a characteristic Miocene form. The newer fauna of these beds is slightly subsequent to that of St. Gérand-le-Puy (generally regarded as upper Oligocene or Aquitanien, although several a u thorities place it in the lower Miocene). (3) The resemblance to the Aquitanien consists in the presence of Rhinocerotoidea-Diceratheriinæ, in the nonappearance of Mastodon among Proboscidea, and in the nonappearance of Teleoceras ainong Rhinocerotoidea. (4) It differs from the Aquitanien proper in the survival of Artiodactyla-Elotheriidæ, which disappear in the middle Oligocene of France. (5) It contains Chalicotheriidæ apparently near Macrotherium, a Miocene stage. (6) From a recent comparison of these fauna, Matthew writes (March, 1907):

The above comparisons indicate that the Rosebud faunæ are later than the upper Oligocene and earlier than the middle Miocene of the European standard. Their position is thereby fixed as lower Miocene, representing an earlier and a later stage.

It is concluded that the upper part of the John Day, for the present, may be somewhat arbitrarily separated as the American upper Oligocene, while the partly contemporaneous and partly sequent Plains formations may be termed lower Miocene.

a Matthew, W. D., A lower Miocene fauna from South Dakota: Bull. Am. Mus. Nat. Hist., vol. 23, 1907 , pp. $169-219$.

"From these discoveries it appears that the Miocene section from the Oligocene to the top of the Nehraska heds, in this general locality, may perhaps have to he regarded as lower Miocene."-Peterson. O. A., The Agate Spring fossil quarry: Ann. Carnegie Mus., vol. 3, No. 4, 1906, p. 491. 
MIOCENE.

IV. FOURTH FAUNAL PHASE-Continued.

LOWER MIOCENE (EUROPE, ÉTAGES AQUITANIEN, BURDIGALIEN).

13. ARIKAREE FORMATION, PROMERYCOCHCERUS ZONE (GERING, MONROE CREEK, HARRISON, AND ROSEBUD OF DARTON, HATCHER, AND MATTHEW).

(Figs. 1, 10, 12-14; Pl. I.)

GENERAL FEATURES.

Geology and nomenclature.-This Great Plains formation, officially designated Arikaree by the Survey was recognized as horizon D by Hayden, and, as shown in the synonymy below (p. 71), has been variously divided and named by Darton, Hatcher, and Matthew. It is

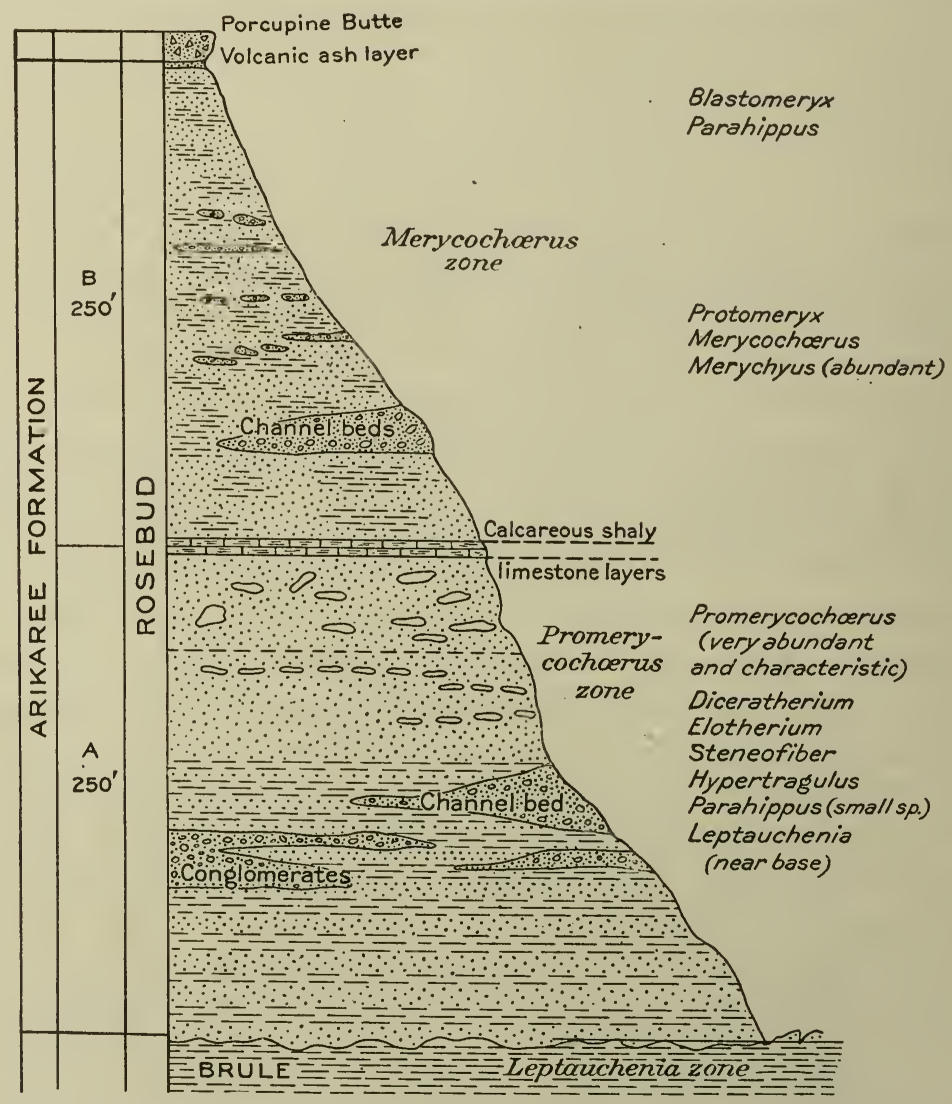

FIG. 12.-Columnar section of the Rosebud formation, after observations by Matthew and Thomson. 1906. For the chief line of this section see section B, PI. II.

extensively exposed along the Pine Ridge Bluffs of South Dakota on the south side of White River and along Niobrara River, as mapped by Darton. $^{a}$ (See Pl. I.) It extends more than 100 miles east and

$a$ Preliminary report on the geology and water resources of the central Great Plains: Prof. Paper U. S. Geol. Survey No.'32, 1905, pl. 35. 
west. It immediately overlies throughout, conformably or unconformably, the upper part of the Brule clay or Leptauchenia zone. In some places lithologically, and everywhere faunistically, it can be divided into lower and upper levels.

Synonymy.--The typical Gering formation of Darton, 1899, is at Scotts Bluff, western Nebraska; the broad extension by Darton of this formation to other localities is somewhat doubtful. The name Gering formation as used by Darton, Hatcher, and Peterson probably applies to noncontinuous river sandstones and conglomerates (maximum 200 feet), which are in a manner analogous to the "Titanotherium," "Metamynodon," and "Protoceras sandstones" that traverse the lower Arikaree clays or finer beds and partly erode irregular channels in the upper Brule clay (Leptauchenia zone). This formation is thus probably of the same age as the lower parts of the Arikaree, Monroe Creek, and Rosebud. Its known fauna is very limited. The so-called Gering of Hatcher and Peterson is in southeastern Wyoming and northwestern Nebraska; in their section it is said to be lithologically similar to the overlying Monroe Creek.

The typical Arikaree formation of Darton, 1899, is at Pine Ridge Bluffs, in South Dakota; whether or not this extends to southeastern Wyoming rests on future paleontological correlation. The Arikaree as described and mapped by Darton would broadly include the whole of the Rosebud formation of Matthew, as well as the Monroe Creek and Harrison, and broadly cover the whole of the Miocene. The entire Arikaree formation of Darton consists of finer materials, whitish or light-buff sandstones, more continuous and widespread, lying either on the Gering formation or on the Brule clay.

There remain to be compared, therefore, the faunæ contained in two sections about 95 miles apart east and west, probably continuous, substantially similar lithologically, and containing a substantially similar fauna. This comparison is based on the valuable recent papers of Peterson and Matthew (cit. supra). The local names Monroe Creek, Harrison, and Rosebud may all be retained until the question of geologic identity or dissimilarity can be settled.

\section{Approximate correlations of the Arikaree formation.}

Westerly section: Southeastern Wyo- Easterly section: South Dakota, Porming and northwestern Nebraska. cupine Creek. Matthew, Gidley, 1904; Hatcher, 1902; Peterson, 1906. (See Matthew, Thomson, 1906. (See fig. fig. 13.)

\begin{tabular}{|c|c|c|c|c|}
\hline \multirow[t]{2}{*}{ Upper division } & Upper part of Harrison & $\begin{aligned} \text { Feet. } \\
200\end{aligned}$ & Upper part of Rosebud. & $\begin{array}{l}\text { Feet. } \\
\text { a } 250\end{array}$ \\
\hline & $\left\{\begin{array}{l}\text { Lower part of Harrison ....... } \\
\text { Upper part of Monroe Creek. }\end{array}\right.$ & $\begin{array}{l}200 \\
300\end{array}$ & & \\
\hline \multirow[t]{2}{*}{ Lower division. } & $\left\{\begin{array}{l}\text { Lower part of Monroe Creek } \\
\text { (Gering of Hatcher and Peter- }\end{array}\right.$ & 200 & Lower part of Rosebud. & a 250 \\
\hline & $\begin{array}{l}\text { Upper part of Brule clay, or Lep- } \\
\text { tauchenia zone. }\end{array}$ & 150 & $\begin{array}{l}\text { Upper part of Brule clay, or Lep- } \\
\text { tauchenia zone. }\end{array}$ & \\
\hline
\end{tabular}




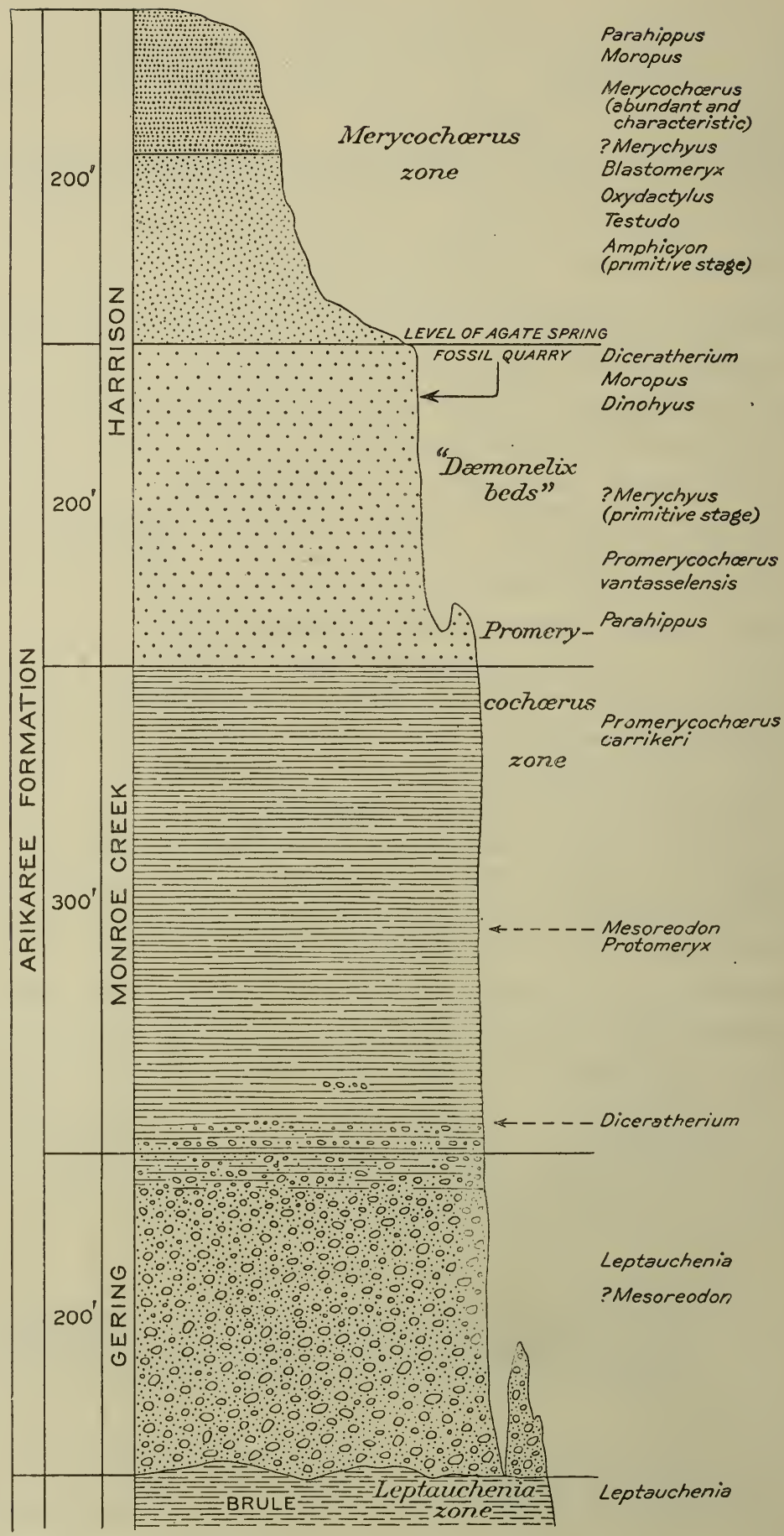

FIG. 13.-Columnar section of the Gering, Monroe Creek, and Harrison formations, based on Peterson's observations in western Nebraska. (See section A, Pl. II.) 
WESTERLY SECTION.

(Figs. 13, 14.)

The recognition of this famma ${ }^{a}$ is the most important advance of recent mammalian paleontology in North America. As opbserved by Peterson, ${ }^{b}$ continuing the observations of Hatcher, ${ }^{c}$ in a section run through northwestern Nebraska and southeastern Wyoming, we find three distinct formations, as described below.

\section{A. LOWER DIVISION.}

(a) Gering formation (or lower part of Monroe Creek).-Among Artiodactyla-Oreodontidæ, Mesoreodon, Leptauchenia. The species of Leptauchenia are but slightly more progressive than those ( $L$. decora, L. nitida) of the underlying Leptauchenia zone or upper part of the Brule clay.

(b) Monroe Creek formation.-Among Artiodactyla-Oreodontidæ, Mesoreodon, Promerycochœrus, Phenacocolus; among Camelidæ,

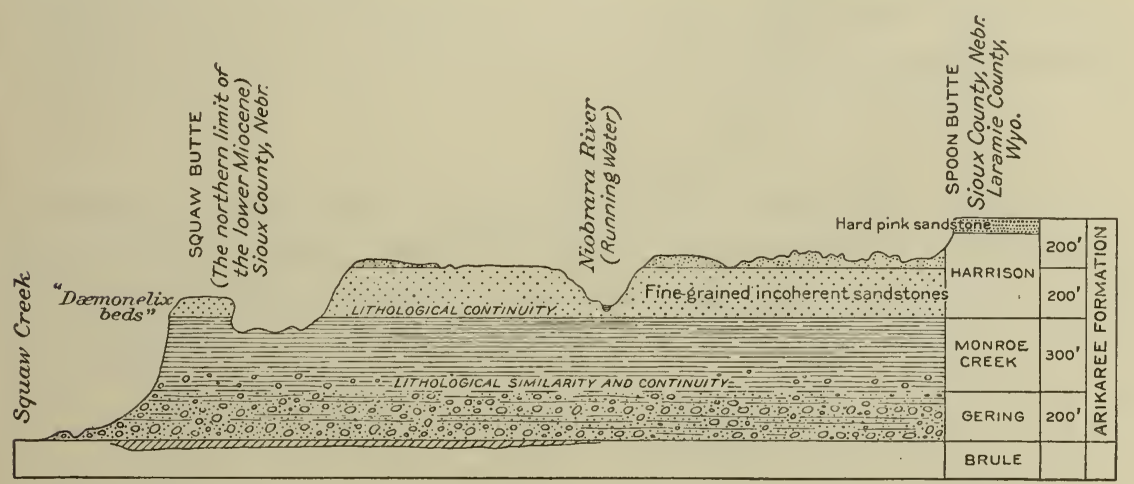

FIG. 14.-Diagrammatic section of the Gering, Monroe Creek, and Harrison formations of western Nebraska. Modified from Peterson, 1906. For the line of this section see section A, Pl. II.

Protomeryx; among Rodentia, Euhapsis platyceps; among Canidæ, Nothocyon; among Rhinocerotidæ. Diceratherium.

(c) Harrison formation, Hatcher.-These are the "Dæmonelix beds" of Barbour. The great spirals or corkscrews to which the name Dxmonelix was applied are found to contain remains of the characteristic lower Miocene rodents, Castoridæ-Steneofiber (an aberrant castoroid), and are believed by Peterson ${ }^{d}$ to represent the burrows of this rodent. The original theory of Barbour (1892) was that these corkscrews represent the spiral roots of some giant plant. Neither theory is entirely satisfactory. The Harrison forma-

$a$ See Appendix, p. 91.

$b$ The Miocene beds, etc.: Ann. Carnegie Mus., vol. 4, 1906, p. 23.

c Origin of the Oligocene and Miocene deposits of the Great Plains: Proc. Am. I'hilos. Soe., vol. 41, 1902, pp. 118-119.

d Mem. Carnegie Mus., vol. 2, 1905, pp. 139-191. 
tion contains, among Oreodontıdæ, Promerycochœrus (P. vantasselensis), Phenacocœlus ( $P$. typus ), also a primitive brachyodont stage of Merychyus; among Camelidæ, two brachyodont genera, namely, Miolabis and a related form, Oxydactylus; Stenomylus, a cameloid of the Hypisodus type; ${ }^{a}$ among Hypertragulidæ, Syndyoceras, ${ }^{b}$ which replaces Protoceras (of the upper Brule level); among Dicotylidæ, primitive species of Desmathyus; among Rodentia-Castoridæ, Steneofiber, very abundant (2 sp.); among Equidæ, Parahippus; among Mustelidæ, Brachypsalis.

(d) Harrison formation, Agate Spring quarry.-Near the middle of the Harrison formation is the extraordinarily rich deposit of this quarry, which gives us a nearly if not quite complete picture of the larger mammals of this region and period. So far as described by Peterson, ${ }^{c}$ it contains, among Perissodactyla-Equidæ, Parahippus; among Rhinocerotidæ, Diceratherium, 2 species; among Chalicotheriidæ, Moropus; among Artiodactyla-Oreodontidæ, Merychyus and ?.Merycochœerus; among Elotheriidæ, Dinohyus, a giant form similar to the large John Day types and probably the last of its family; among Carnivora-Canidæ, Nothocyon, Amphicyon (a very primitive form, its earliest appearance in America).

B. LPPER DIVISION.

(e) Upper part of Harrison formation. -Among ArtiodactylaOreodontidæ, Merycochorus (first abundant appearance of this genus), Merychyus; among Camelidæ, ? Miolabis and Oxydactylus, 2 species; the first appearance of the family Cervidæ, genus Blastomeryx, a modernized selenodont artiodactyl; Dicotylidæ, Desmathyus; among Perissodactyla-Equidæ, Parahippus, a large brachyodont horse constituting the most abundant type and most characteristic stage; among Chalicotheriidæ, Moropus; among Carnivora-Mustelidæ, Elurocyon. Also 2 species of Testudo.

\section{EASTERLY SECTION.}

(Fig. 12.)

About 90 miles farther east along Pine Ridge in northern Nebraska and on the south side of White River is the formation, also overlying the upper Brule clay, named by Matthew and Gidley ${ }^{e}$ (1904) the Rosebud beds. This is the region of the typical Arikaree section of Darton, described and named in 1899. The section (fig. 12) was made by Albert Thomson, of the American Museum expedition of 1906.

a Peterson, op. cit.

$b$ Barbour, E. H., Notice of a new fossil mammal from Sioux County, Nebr.: Nebraska Geol. Survey, voi. 2 , pt. 3 .

c The Miocene beds of western Nebraska, etc.: Ann. Carnegie Mus., vol. 4. 1906, pp. 21-i2.

$d$ Erroneously termed "Nebraska" in Peterson's first report. The Agate Spring fossil quarry: Ann: Carnegie Mus., vol. 3, 1906, p. 487.

e New or little known mammals from the Miocene of South Dakota: Bull. Am. Mus. Nat. IIist., vol. 20, 1904, pp. 241-268. 
As analyzed by Matthew ${ }^{a}$ it is to be noted that: (1) The Rosebud fauna contains no new immigrants, but is mainly a further development of the John Day fauna; all the animals exhibit slightly or decidedly more progressive stages. For example, the camels of the Monroe Creek, Harrison, and Rosebud are decidedly more advanced than anything from the upper part of the John Day, as are also the. horses, carnivores, rodents, and oreodonts. (2) This fauna was distributed farther out in the Plains Region, a circumstance that may have differentiated it locally from the more westerly fauna of the Monroe Creek and Harrison formations, which was presumably near the sources of the water supply, forests, etc. This fact of local distribution may account for some differences in comparison with the Monroe Creek and Harrison lists above. These differences may be reduced or increased by further exploration.

\section{A. LOWER PART OF ROSEBUD.}

Homotaxis.-1, Lower part of Rosebud of Matthew; 2, Gering of Darton, Hatcher, and Peterson; 3, Monroe Creek of Hatcher; 4, Harrison of Hatcher; 5, Middle portion of "Martin Canyon beds" of Matthew, Colorado.

Fauna. ${ }^{b}$-Among Carnivora, Nothocyon, Mesocyon, Enhydrocyon, Nimravus; among Rodentia, Entoptychus, Steneofiber, Euhapsis, Meniscomys, Lepus; among Perissodactyla, Parahippus, ?Anchitherium, Diceratherium; among Artiodactyla, Elotherium, Eporeodon, Mesoreodon, Promerycochorus (very abundant and characteristic), Leptauchenia, and Hypertragulus.

B. UPPER PART OF ROSEBUD.

Homotaxis.-1, Upper part of Rosebud of Matthew. 2, Deposits near Laramie Peak, Wyoming. 3, Upper part of IIarrison of Peterson, western Nebraska. 4, Summit of "Martin Canyon beds" of Matthew, Colorado.

Fauna.-(1) Few species pass from the lower part of the Rosebud into the upper part. (2) The Elotheriidæ, Hypertragulidæ, and Promerycochœrus have probably disappeared. (3) The Diceratheriinæ continue. Among Carnivora, Cynodesmus, Megatictis, Oligobunis. Among Insectivora, Arctoryctes (a supposed member of the Chrysochloridæ). Among Rodentia-Geomyidæ, Entoptychus, Lepus, and a heteromyid. Among Perissodactyla, 2 families: Parahippus, other Equidæ, Diceratherium. Among Artiodactyla, 4 families: (a) Dicotylidæ, Desmathyus; (b) among Oreodontidæ, Merychyus is extremely abundant and characteristic; Merycochorus also appears for the first time; (c) Camelidæ, Protomeryx; $(d)$ Cervidæ, Blastomeryx.

a A lower Miocene fauna from South Dakota: Bull. Am. Mus. Nat. Hist., vol. 23, 1907, pp. 169-219.

$b$ See Appendix, p. 91 . 


\section{FIFTH FAUNAL PHASE.}

Fresh migrations via Eurasia-First appearance of African Proboscidea, of true Felinæ among the Felidæ, of short-limbed Teleocerinæ among Rhinocerotoidea, animals occurring in the lower Miocene of EuropeEvidence of increasing summer droughts.

MIDDLE MIOCENE (EUROPE, ÉTAGES HELVÉTIEN, SARMATIEN, TORTONIEN).

\section{FAUNAL CHANGES.}

1. North America.-In the formations which are now commonly classed as middle Miocene, but which may prove to represent lower and middle Miocene, we meet another very profound change in the mammals of North America. This change is threefold: It consists ( $a$ ) in the occurrence of more advanced evolutionary stages, among the Camelidæ and Equidæ especially; $(b)$ in the extinction of many mammals characteristic of the Harrison or upper Rosebud or lower Arikaree, which we are here considering lower Miocene; $(c)$ in the sudden appearance of a large number of new forms of African (Proboscidea) and Eurasiatic (e. g., Rhinocerotidæ, Teleocerinæ, Pecora) origin. The appearance of several modernized selenodont artiodactyls or Pecora must have effected a change in the external aspects of the fauna which was only less striking than that caused by the mastodons and the bulky rhinoceroses.

2. Europe.-As regards $(b)$ and (c), a similar extinction and sudden appearance also mark the base of the European Miocene, the Langhien or Burdigalien as represented by the Sables de l'Orléanais of Europe. The conclusion is that these North American middle Miocene formations contain animals which first appear in the lower Miocene of Europe, just as the American lower Miocene contains animals which first appear in the upper Oligocene of Europe. At least, this is the hypothesis on which our correlations are based at present, allowing considerable time for migration from the old to the new world.

14. DEEP RIVER SEQUENCE, SCOTT; TICHOLEPTUS ZONE, COPE.

(Figs. 1, 10; Pl. I.)

HOMOTAXIS.

America.-This is in large part the "Loup Fork fauna" of Cope's descriptions, because his materials were chiefly from this level in Colorado and Oregon beds. (a) Central Plains: 1, Horizon E of Hayden and Leidy; 2, "Pawnee Creek beds" of Matthew, northeastern Colorado (75 feet), immediately overlying the Harrison; 3, "Panhandle beds" of Gidley, northwestern Texas. (b) Northern Plains: 4, Upper part of Deep River sequence (Smith Creek) or Ticholeptus zone (of Cope), Montana; 5, "Flint Creek beds" of 
Douglass (150 feet), Montana. (c) Mountain Region: 6, Mascall formation, Oregon (lower part, 1,000 feet), capping the (olumbia River lava (1,000 feet), which in turn overlies the John Day formation. The Colorado (Matthew ${ }^{a}$ ) and Montana (Scott, ${ }^{b}$ Douglass ${ }^{c}$ ) faunæ are the best known and are closely equivalent in age.

Europe.-Honotaxis with Europe is provisional, owing to: (1) Uncertainty as to what we should regard as the base of the American Miocene; (2) uncertainty as to the speed or rate of migration from Europe. The new mammals of this stage (viz, Proboscidea, Teleocerinx, and Pecora) are all from Europe, where they form the chief characteristics of the lower Miocene; but we may suppose that these animals occupied a portion of the lower Miocene period in migrating from western Europe to North America.

\section{FAUNA. ${ }^{d}$}

1. Scott first $\left(1893^{e}\right)$ fully characterized the upper Deep River fauna of Montana as prior to the so-called "Loup Fork" of Colorado.

2. Matthew ${ }^{f}$ first (1901) clearly distinguished the fauna of our so-called middle Miocene ("Pawnee Creek") from that of the upper Miocene or typical Niobrara River "Loup Fork" of Hayden, and the above correlations are chiefly due to him.

3. Its negative characters are: Nonoccurrence of ArtiodactylaElotheriidæ and Hypertragulidæ (which apparently became extinct during the lower Rosebud); of Perissodactyla-Diceratheriinæ (which apparently became extinct during the upper Rosebud).

4. Its positive or new characters are: (1) The first appearance of Proboscidea by migration from Africa. (2) By migration from western Europe or Eurasia: Among Carnivora 2 new and distinctive Eurasiatic subfamilies-(a) true Felidæ-Felinæ, Pseudælurus; (b) Canidæ-Amphicyoninæ, Amphicyon. Among Perissodactyla-Rhinocerotoidea, a member of the Teleocerinæ closely similar to the lower Miocene Teleoceras aurelianensis of France. Among Artiodactyla-Cervidæ, Palæomeryx; other peculiarly American modernized ruminants, Merycodus (family Antilocapridæ), date from this stage. Among Rodentia the new family Mylagaulidæ (also American) appears. Thus in our so-called middle Miocene the peculiarly American Hypertragulidæ disappear; the European Cervidæ and the peculiarly American Merycodontinæ take their places.

$a$ Matthew, W D., Fossil mammals of the Tertiary of northwestern Colorado: Mem. Am. Mus. Nat. Hist., vol. 1, pt. 7, Nov., 1901, pp. 355-447.

$b$ Scott, W. B., The Mammalia of the Deep River beds: Trans. Am. Philos. Soc., n. s., vol. 18, 1895, pp. 55-185.

$c$ Douglass, Earl, The Neocene lake beds of western Montana: Univ. Montana, doctorate thesis

June, 1899. New vertebrates from the Montana territory: Ann. Carnegie Mus., vol. 2, 1903.

$d$ See Appendix, p. 91 .

$e$ Scott, W. B. The mammals of the Deep River beds: Am. Naturalist, vol. 27, 1893, pp. 659-662. The Mammalia of the Deep River beds: Trans. Am. Philos. Soc., n. s., vol. 18, 1895, pp. 55-185.

$f$ Matthew, W. D., op. cit., pp. 358-374. 
Plains fauna.-Of local evolution on the Great Plains the Equidæ exhibit, as the most distinctive genus, the first of the Hippotheriinæ or Merychippus stage of horses with subhypsodont molar teeth; the large brachyodont Hypohippus is also found, as well as Parahippus. Among Rhinocerotidæ, the hornless Aphelops first occurs, also Teleoceras. Among Tapiridæ, Tapirarus. Among Camelidæ, Miolabis continues, Protolabis appears, and Alticamelus succeeds Oxydactylus. Among Oreodontidx, the family reaches a climax of differentiation in 7 genera, including Merychyus and Merycocharus, but adding the very characteristic genera Ticholeptus and Cyclopidius, which are probably direct descendants of Eporeodon and Leptauchenia of the preceding stage. Among Rodentia-Mylagaulidæ, Mylagaulus, Ceratogaulus. Among Canidæ, Cynarctus, Amphicyon, and other less aberrant genera.

Mountain Region fauna of the Mascall formation.-The Mascall formation of Oregon, overlying the Columbia River lava and subjacent John Day, is partly homotaxial with the middle and upper Miocene. The fauna, sparsely known, includes very primitive horses with short-crowned teeth (Archæohippus, Parahippus): also the more progressive Merychippus, which is characteristically middle Miocene, although it persists into the upper Miocene. We find Miolabis among Camelidæ. Among Cervidæ, Palæomeryx. Among Proboscidea, Trilophodon. An ungual phalanx of the Edentata-Grarigrada type is certainly reported from these beds (Sinclair); the true South American Gravigrada are first known to occur in the middle Pliocene (Blanco formation of Texas).

\section{MOUNTAIN REGION FLORA.}

The flora seems to point to a more recent age for these beds, but American floræ generally are more progressive than the rertebrate fauna. The Mascall flora was considered upper Miocene by Lesquereux. Knowlton ${ }^{a}$ also concludes that the flora is of upper Miocene age; from his list cited by Merriam ${ }^{b}$ (1901), Hollick ${ }^{c}$ observes:

I judge that the meteorological, climatal, and physiographic conditions indicated would be comparable to those now met with on the Atlantic coastal plain at about the latitude of the Carolinas. A majority of the trees, such as Salix, Quercus, Planus, Aralia, Acer. Prunus, etc., belong to the Temperate Zone, and represent a flora similar to that of this vicinity [New York, lat. $42^{\circ} \mathrm{N}$.]. Accompanying these, however, are a few of more southern distribution. such as Taxodium, Laurus, Sapindus, and Ficus?, which indicate that the flora as a whole should be regarded as warm-temperate. The indicated moisture factor is a little more difficult to determine. Marsilea is an aquatic plant. and the characteristic habitat of Taxodium is swamp land, while the other genera might represent either lowland or upland species.

a Knowlton, F. H., Fossil flora of the John Day basin: Bull. U. S. Geol. Survey No. 204, 1902, p. 108.

$b$ Merriam, J. C., A contribution to the geology of the John Day basin: Bull. Dept. Geology, Univ. California. vol. 2. 1991.pp. 30s. 309.

c Letter of February 6, 1906. 
UPPER MIOCENE (EUROPE, ÉTAGE PONTIEN).

15. OGALALLA FORMATION (IN PART); PROCAMELUS ZONE.

(Figs. 1, 10; Pl. I.)

\section{HOMOTAXIS AND SYNONYMY.}

North America.-This includes the "Loup Fork" of Leidy, Marsh, also of Scott and Osborn, in part. 1, "Nebraska" of Scott, 1894, western Nebraska. ${ }^{a}$ 2, Cosoryx zone, Scott, ${ }^{b}$ 1894. (The genus Cosoryx is preoccupied by Merycodus, so it appears that this name can not be used.) 3, Ogalalla and Arikaree of Darton (in part), 1899, western Nebraska. 4, Protohippus zone of Osborn, 1907. 5, "Santa Fe marls" of Cope, New Mexico. 6, "Clarendon beds" of Gidley, Llano Estacado, northwestern Texas (75 feet). Northern Plains: 7, "Madison Valley beds" of Douglass, Montana (1,200 feet).

Europe-Etage Pontien, Pikermi, Eppelsheim. The so-called "Loup Fork mammals," although including Hipparion, are not quite so modernized as those of Eppelsheim and Pikermi, which should be regarded as lower Pliocene.

This fauna has become universally known as the "Loup Fork fauna" (Cope, 1877), owing to errors on the part of Hayden, Leidy, Cope, and their successors, arising from the confusion of late Miocene and upper Pliocene faunæ. But, as shown fully on page 84 , the term "Loup Fork" is equivalent to "Loup River," and the latter term was originally applied so as to include an upper Pliocene or lower Pleistocene formation containing Elephas imperator.

\section{FAUNA. ${ }^{c}$}

This is one of the best known, most widely distributed, and most characteristic faunæ in all the Tertiary series. There is no evidence of a fresh Eurasiatic migration, but rather of rapid local evolution. The genus Protohippus distinguishes it clearly from the middle Miocene, which contains Merychippus only. Other new distinctive genera are the camels Procamelus and Pliauchenia, the horse Neohipparion, and the rhinoceros Peraceras. The wide distribution of a similar fauna at this stage indicates widespread conditions of aridity and a uniformly favorable environment, summer droughts probably lengthening and eolian deposits increasing. From Montana on the northwest and Texas on the southwest to Nebraska in the central west we find a very similar list of animals; so the homo-

a Bull. Geol. Soc. America, vol. 5, 1894, p. 595.

$b$ Under a misapprehension as to Scott's definition of the term " Nebraska," both Hatcher and Peterson first applied this term to a part of the lower A rikaree or lower Miocene.

c Matthew, W. D., and Gidlev, J W., New or little known mammals from the Miocene of South Dakota: etc.: Bull. Am. Mus. Nat. Hist., vol. 20, 1904, pp 241-2;8, See Appendix, p. 91. 
taxis of the American horizons "Nebraska," "Clarendon beds," "Santa Fe marls," and "Madison Valley beds" is singularly well established.

Among Rodentia-Mylagaulidæ, 1 genus. Among Sciuridæ, 2 genera. Among Carnivora-Canidæ, Elurodon, Cynodesmus(?), Borophagus, Dinocyon('), and Ischyrocyon. Among Mustelidæ, Mustela, Lutra, Potamotherium, Brachypsalis, Putorius. Among Felidæ, Pseudælurus (Felis of Leidy), and large machærodonts of uncertain genus. Among Procyonidæ, Leptarctus. Among Perissodactyla, 3 families: (a) among Equidæ (5 genera), Protohippus (5 or more species), Neohipparion (5-12 species) with long crowned teeth, Merychippus persisting with intermediate teeth, Hypohippus and Parahippus (Montana) persisting with short-crowned teeth; (b) among RhinocerotidæTeleocerinæ, 2 genera of the short-limbed type occur-Teleoceras, Peraceras, also Aphelops ceratorkinus; (c) among Tapiridæ, Tapirazus. Among Artiodactyla, 5 families: (a) Camelidæ, including Pliauchenia (its first appearance, 2 or more species), Procamelus (its first appearance, 2-7 species); (b) among Oreodontidæ, Merycochœrus (2 species, Montana), Merychyus, Pronomotherium; (c) among Merтcodontinæ, Merycodus; (d) among Dicotylidæ, Prosthennops (Montana); (e) among Cervidæ, Palæomeryx (5 species), Blastomeryx. Among Proboscidea there occur the long-jawed types analogous to Tritophodon angustidens of Europe.

LAST PHASE OF MIOCENE OR FIRST PHASE OF PLIOCENE (EUROPE, ÉTAGES PONTIEN. MESSINIEN).

A late phase of Miocene, or early phase of Pliocene, is the deposit on Republican River, in northern Kansas. It is, provisionally and subject to further exploration, distinguished (Matthew) from the so-called "Loup Fork," or "Nebraska," of Scott. Its fauna presents certain parallels with the Pikermi and Eppelsheim fauna (placed by Depéret in the upper Miocene) of Europe, eren if not of more recent age. It is widely separate from a second and much later phase, represented in the Blanco formation of northwestern Texas, which is much more recent in its fauna and is here regarded as middle Pliocene.

16. OGALALLA FORMATION (IN PART): PERACERAS ZONE.

(Figs. 1, 10; Pl. I.)

\section{HOMOTAXIS.}

America.-1, Upper "Loup Fork" (100 feet) of Republican River, northwestern Kansas. 2, Ogalalla formation (typical), Darton, of southwestern Nebraska. 3, "Archer formation" of Florida (in part). 4, Rattlesnake formation of John Day Valley, Oregon.

Europe--Pontien: Eppelsheim, in northern Europe; Pikermi, in Greece; Mont Léberon, Vaucluse, France. 


\section{FAUNA."}

From our present knowledge, the close of the Miocene or advent of the Pliocene may be characterized: Negatively, (1) by the absence of Artiodactyla-Oreodontidæ and the rarity of Merychyus, Merycochorus, etc., which thus far are represented only by fragmentary specimens; (2) by some reduction in the number of Camelidæ (in this family Pliauchenia is now the characteristic genus); (3) by the rarity of the browsing horses (Hypohippus); (4) by the disappearance of the Perissodactyla-Chalicotheriidæ. Probably some of these absent forms will be unearthed by future exploration. Positively, (1) by the more advanced evolution of the Rhinocerotidæ in progressive species of Teleoceras, Peraceras, and Aphelops; (2) by more progressive but still long-jawed forms of Proboscidea-Mastodontidæ, with four or more crests on the molar teeth.

Characteristic animals are: Among Rodentia-Mylagaulidæ, Mylagaulus, also a new and more specialized genus, Epigaulus Gidley; among Castoridæ, Dipoides; among Carnivora, both Felinæ and Machærodontinæ; among Canidæ, Elurodon, ? Dinocyon; among Rhinocerotidæ, Teleoceras, Peraceras, Aphelops, including the progressive species A. malacorhinus; among Equidæ, Protohippus; among Artiodactyla, 4 families, (a) Dicotylidæ, Prosthenops; (b) Camelidæ, Procamelus, Pliauchenia (a large form), Alticamelus (typical in the Rattlesnake formation, Oregon); (c) Merycodontinæ, Merycodus; (d) Cervidæ, Blastomeryx; among Proboscidea, Trilophodon campester and T.euhypodon are recorded, both with long jaws.

16a. RATTLESNAKE FORMATION (200 FEET) OF JOHN DAY VALLEY, OREGON.

(Figs. 1, 10; Pl. I.)

The sparsely known fauna of this formation, as determined by Merriam, ${ }^{b}$ Sinclair, and Gidley, contains the tortoise Clemmys hesperia Hay. Among mammals: Perissodactyla, (a) Equidæ, Pliohippus supremus, (b) Rhinocerotidæ-?Teleocerinæ, indet.; Artiodactyla, (a) Dicotylidæ, indet., (b) Camelidæ, Alticamelus altus (the typical fórm), also Pliauchenia; large species of Procamelus still survive.

\section{PLIOCENE.}

Homotaxis.-Pliocene homotaxis must be prefaced by the statement that the American fauna is sparsely and imperfectly known as yet, and that correlations with Europe (étages Messinien, Plaisancien, Astien) are very provisional. The gaps will undoubtedly be filled eventually.

$b$ A contribution to the geology of the John Day basin: Bull. Dept. Geology, Univ. California, vol. 2, 1901, pp. 310-312.

56092-Bull. $361-09-6$ 
VI. SIXTH FAUNAL PHASE.

Land connection with South America reestablished-Invasion of South American Edentata-Gravigrada and Glyptodontia-Migration of North American mammals to South America.

Decidedly distinct and more recent than either the typical "Loup Fork," the upper "Loup Fork" deposits on Republican River, Kansas, or the Rattlesnake formation, is the Blanco formation of Texas.

MIDDLE PLIOCENE OR SECOND PHASE (EUROPE, ÉTAGE ASTIEN).

17. BLANCO FORMATION; GLYPTOTHERIUM ZONE.

(Fig. 15; Pl. I.)

HOMOTAXIS.

North America.-Plains fauna: 1, Blanco formation of Cummins, ${ }^{a}$ Cope, ${ }^{b}$ Gidley $^{c}$ (100 feet), Llano Estacado of Texas. 2, Ogalalla formation of Darton (? in part), northwestern Nebraska.

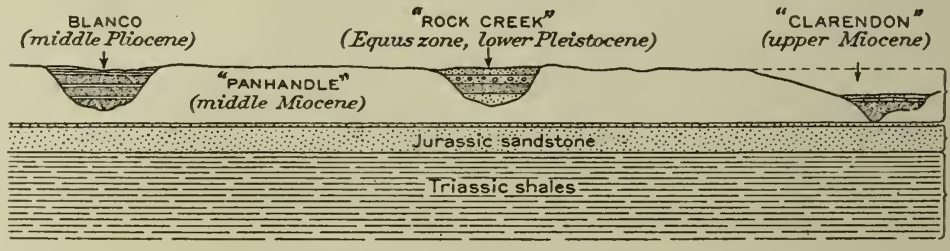

FIG. 15.-Diagrammatic section of the Staked Plains (Llano Estacado), Texas, showing the relations of the "Clarendon"'(or Protohippus zone), "Rock Creek" (or Equus zone), and Blanco (or Glyptotherium zone) to the underlying "Panhandle" (or ? Merycochœrus zone). After J. W. Gidley, 1908.

\section{FAUNA. ${ }^{d}$}

This faunal phase is clearly characterized negatively: (1) By the undoubted extinction of the Oreodontidæ, (2) by the apparent extinction of the Rhinocerotidæ, (3) by the apparent but not yet fully demonstrated absence of the forest or browsing horse Hypohippus. It is distinguished from the upper Pliocene of Europe (étage Sicilien) by being antecedent to the appearance of the genera Equus and Elephas. It is characterized very positively: In Texas (4) by the first appearance of South American Edentata-Gravigrada, Mylodon, Megalonyx; (5) also by the first appearance of Glyptodontia Glyptotherium; (6) in Texas and Nebraska by short-jawed Proboscidea with molar teeth in some respects resembling the Stegodon type, Dibelodon mirificus.

$a$ Cummins, W. F., Notes on the geology of northwest Texas: Third Ann. Rept. Geol. Survey Texas, 1831 (1892), pp. 129-200; Fourth Ann. Rept., 1892 (1893), pp. 179-238.

$b$ Cope, E. D., A preliminary report on the vertebrate paleontology of the Llano Estacado: Fourth Ann. Rept. Geol. Survey Texas, 1892 (1893), pp. 1-136.

c Gidley, J. W., The fresh-water Tertiary of northwestern Texas, etc.: Bull. Am. Mus. Nat. IIist., vol. 19, 1903 (Blanco), pp. 624-632.

$d$ See Appendix, p. 91 . 
The fossiliferous horizon on Loup River in Nebraska which yielded Dibelodon mirificus has not been recently explored. 'The fauna is sparsely known from the Blanco formation of Texas. It includes among Carnivora-Canidæ, Borophagus, Amphicyon being doubtfully present; among Mustelidæ, Canimartes; among Felidæ, Felis hillianus, the earliest positively known appearance of Felis. Among Proboscidea from this level is Dibelodon mirificus (Nebraska, Texas); among Artiodactyla-Dicotylidæ, the large cursorial peccary Platyqonus first appears; among Camelidæ, Pliauchenia of very large size; among Equidæ, Neohipparion and Protohippus continue; among Edentata-Glyptodontia, Glyptotherium resembles Panochthus of the Pampean in type, but is less specialized; Megalonyx and Mylodon occur.

\section{UPPER PLIOCENE OR LOWER PLEISTOCENE.}

18. ELEPHAS IMPERATOR ZONE.

HOMOTAXIS.

North America.--1, Horizon $\mathrm{F}$ of Hayden and Leidy, upper part only. 2, "Loup River" of Meek and Hayden, 1861-62, Nebraska. 3 , Certain formations (unnamed) in Texas and Mexico, containing Elephas imperator.

Europe.-In Europe the uppermost Pliocene is distinguished by the disappearance of Hipparion and the advent of Elephas (E. meridionatis) and Equus (E. stenonis).

\section{HISTORY AND SYNONYMY.}

According to the decision of the committee on geologic names of the Geological Survey, the typical beds of this stage may for the present be known as upper Pliocene or Elephas imperator zone. The ground for this decision is the confusion in the application of the terms "Loup River" and "Loup Fork," which apply to the same stream; also the confusion in the usage of the term "Loup Fork."

Horizon F, or the typical "Loup River beds," on "Loup Fork of Platte River, extending north to Niobrara River and south to an unknown distance beyond the Platte," were first characterized by Meek and Hayden ${ }^{a}$ (1861-62) as follows: "Fine loose sand, with some layers of limestone-contains bones of Canis, Felis, Castor, Equus, Mastodon, Testudo, etc., some of which are scarcely distinguishable from living species." Of the bones collected in this locality Leidy ${ }^{b}$ observed in 1869: "Other remains of elephants, as Doctor Hayden supposes them to be, he observed in association with those of Mastodon mirificus, Equus excelsus, and Hipparion at the head of the Loup Fork branch of the Platte River; also between this point and

a Proc. Acad. Nat. Sci. Philadelphia, rol. 13, 1861 (1862), p. 433.

$b$ Extinct mammalian fauna of Dakota and Nebraska, 1869, p. 255. 
the Niobrara River and on the latter." These species were determined by Leidy as follows: Elephas imperator Leidy, Mastodon mirificus Leidy, Equus excelsus.

The type of Equus excelsus is elsewhere stated to be from the "Pawnee Loup branch of the Platte or Niobrara River." In the same $\operatorname{article~}^{a}$ a somewhat fuller description of the "Loup River beds" makes them include all the deposits down to the top of the White River group, and the faunal list contains several Miocene genera in addition to the more modern types first cited.

The term "Loup River" was again employed by Hayden in 1862, 1869 (introduction to Leidy's memoir), 1871, and 1873.

It is unfortunate that this upper Pliocene or lower Pleistocene horizon, although fairly well defined both geographically and faunistically, should have been confused by Hayden and Leidy themselves (see 1869, pp. 15-21) with the very much older horizon or true upper Miocene, as part of their Horizon F, including the very rich upper Miocene faunal list. Thus Cope, ${ }^{b}$ while referring to the very same Nebraska fauna which was described by Leidy c in 1858, applies the terms "Loup Fork epoch" and "Loup Fork beds" to the "Santa Fe marls" of New Mexico. The error thus spread into all the subsequent literature. It appears, therefore, that: (1) "Loup River" is the original name. (2) "Loup River" originally included an upper Pliocene or lower Pleistocene horizon. (3) "Loup Fork" is essentially the same name; it is a synonym of "Loup River;" it was defined in still another sense and has been generally used in a very different sense, and must drop out of use entirely.

\section{PLEISTOCENE.}

\section{SEVENTH FAUNAL PHASE.}

Increasing cold, moisture, and forestation-Third modernization by a gradual Eurasiatic invasion of hardy, forest, fluviatile, mountain (alpine), plains, and barren-ground fauna-Gradual extinction of the larger Ungulata, of the native North American stocks, of the South American invading stocks, of the Miocene invading Eurasiatic and African stocks.

\section{LOWER PLEISTOCENE (PREGLACIAL).}

Our knowledge of the mammals in this period is still confined to the western plains and mountains.

The American Pleistocene begins either with the Elephas imperator zone (referred above to the upper Pliocene) or with the Equus zone. The exact position of the Elephas imperator zone, also the question whether it is of the same age as the Equus zone, remain to be determined. In the present review only a few of the characteristic Pleistocene deposits will be included, because the subject of Pleistocene correlation and succession is in its infancy. 


\section{EQUUS ZONE.}

HOMOTAXIS.

America.-Plains and border fauna. 1, "Sheridan formation" (Scott ${ }^{a}$ ) or, 2, Equus zone, Hay Springs, northwestern Nebraska. 3, "Rock Creek beds" (Gidley ${ }^{b}$ ), Tule Canyon, Llano Estacado, Texas. Widely scattered and numerous deposits in Great Plains and Mountain regions, some of which have received distinct formation names.

Europe.-Preglacial. Forest beds of Norfolk (England); St. Prest (Eure-et-Loire); Durfort (Gard), containing Elephas meridionalis (its last appearance). The European fauna of this period includes (Osborn, ${ }^{c}$ 1900) 12 Pliocene species, 32 Pleistocene species and races, now extinct, and 17 living species (7 Insectivora, 1 Cheiroptera.)

\section{FAUNA. ${ }^{d}$}

It is noteworthy (Matthew, ${ }^{e}$ 1902) that chiefly the Plains fauna and no purely forest fauna of this phase is known, a fact which may account for the nonappearance of certain forest-living types. There is some evidence of increasing moisture and of the renewal of streams and of forests; for example, at Hay Springs, northwestern Nebraska (a slightly earlier phase), the presence of streams is indicated by Fiber, of -wooded rivers by Castoroides. In Silver Lake, Oregon (a slightly more recent phase), a partly fluviatile and wooded country is indicated by Fiber, Lutra, Castor, and Castoroides.

The mammal fauna $e$ is characterized negatively (1) by the absence or disappearance of Perissodactyla-Rhinocerotidæ, (2) by the nonappearance of Bovidæ or Ursidæ. It is characterized positively by the first appearance (3) among Equidæ, of Equus (3 species); (4) among Proboscidea, of Elephas (2 species), E. columbi, E. imperator; $;$ (5) among Artiodactyla, of the distinctively American genus Antilocapra; among Camelidæ, of Camelus; among Rodentia, of 6 new modern genera and the first appearance of the extinct Castoroides.

More in detail, among Rodentia of Nebraska and Oregon occur 8 existing genera of the same region, Arvicola, Fiber, Thomomys, Geomys, Cynomys, Castor, Lepus, and Castoroides; among CarnivoraCanidæ, Canis (3 species); among Mustelidæ, Lutra; among Felidæ, Felis; among Edentata, Mylodon and Paramylodong (plains or river-

$a$ Bull. Geol. Soc. America, vol. 9, 1898, p. 406.

$b$ The fresh-water Tertiary of northwestern Texas: Bull. Am. Mus. Nat. Hist., vol. 19, 1903, p. 622.

$c$ Correlation, etc.: Ann. New York Acad. Sci., vol. 13, 1900, p. 38.

$d$ See Appendix, p. 91.

e Matthew, W. D., List of the Pleistocene fauna from Hay Springs, Nebraska: Bull. Am. Mus. Nat. Hist., vol. 16, art. 24, Sept. 25, 1902, pp. 317-322. Cope, E. D., The Silver Lake of Oregon and its region: Am. Naturalist, vol. 23, 1889, pp. 970-982.

$f$ As noted on p. 83, E. imperator may represent a late Pliocene phase.

$g$ Brown, Barnum, Bull. Am. Mus. Nat. Hist., vol. 19. 1903. nn. 56i9-583. 
border types); among Perissodactyla-Equinæ, only 3 species; among Artiodactyla, 4 families: (a) Camelidæ, Eschatius, Camelops (2 species), Camelus; (b) Dicotylidæ, Platygonus; (c) Antilocapridæ, Antilocapra (first appearance); (d) Merycodontinæ (last appearance of this peculiarly American subfamily, genus Capromeryx); among Proboscidea, Elephas columbi, E. imperator. In the "Rock Creek beds" of Texas is found a supposed Dinocyon (Borophagus) or one of the Ursidæ.

\section{MIDDLE PLEISTOCENE (GLACIAL).}

\section{GENERAL CHARACTERS.}

Our knowledge of the American mammals now for the first time becomes continental because it represents deposits in all parts of North America.

The general characters of the middle Pleistocene as a whole may be summarized as follows:

1. This long period, which will eventually be divided into faunal substages, as in Europe, is distinguished negatively by the absence of the lower Pleistocene mammals (1) Elephas imperator and (2) Artiodactyla-Merycodontinæ, and (3) by the gradual extinction of the resident large quadrupeds.

2. It is marked chiefly by the gradual invasion of a Eurasian hardy and boreal fauna and thus distinguished positively by the first recorded appearance (1) of Ursidæ; (2) of Bovidæ-(a) Ovinæ, (b) Bovinæ, (c) Rupricaprinæ; (3) of 3 genera of the larger northern Cervidæ, namely, Alces, Odocoileus, Cervus (it is noteworthy that Rangifer does not appear in our mid-Pleistocene); (4) among Proboscidea, Elephas primigenius and E. columbi succeed E. imperator, and the appearance of Mastodon americanus is first recorded.

3. The hardy forest and glade fauna both east and west increase in number and variety, including the Cervidæ and Ursidæ.

4. The resident plains and forest-border grass-eating forms (Equidæ, Camelidæ, Elephantinæ) diminish in number and gradually disappear.

5. Among all the larger Carnivora and Herbivora only 3 resident families, namely, the Canidæ, Dicotylidæ, and Antilocapridæ, survive.

6. Thus all the less hardy previously invading Eurasiatic, South American, and native North American animals disappear.

7. Thus again we note the gradual extinction (1) among Edentata of the South American Gravigrada and Glyptodontia, (2) among Perissodactyla of the indigenous North American Tapiridæ and Equidæ, among Camelidæ of Camelus, among Carnirora of the Machærodontinæ or saber-tooths; (3) among Eurasiatic forms of the Elephantinæ.

8. The question of latitude, or more northerly. or southerly distribution, becomes more important on account of the increasing cold. 
The divisions of the mid-Pleistocene will ultimately be clearly marked off, first by the successive disappearance and extinction of the less hardy lower Pleistocene forms, second by the appearance or invasion of the more hardy modernized forms.

The following table is merely approximate:

Order of appearance and disappearance of lower Pleistocene forms.

APPEARANCE.

\section{Early Pleistocene}

Mylodon (central).

Paramylodon.

Platygonus.

Elephas columbi.

Antilocapra.

Camelus.

\section{Mid-Pleistocene.}

Elephas primigenius.

Mastodon.

Odocoileus.

Haploceras.

Erethizon.

Bison.

Alces.

Ovibos.

Cervus (late).

Ursus (late).

Rangifer (late).
DISAPPEARANCE.

Early Pleistocene.

Elephas imperator.

Capromeryx.

?Paramylodon.

Mid-Pleistocene.

Camelus.

Mylodon.

Megalonyx.

Tapirus.

Arctotherium.

Elephas columbi.

Elephas primigenius.

\section{Upper mid-Pleistocene.}

Smilodontopsis.

Mastodon.

Equus.

Mylohyus.

\section{EARLY PHASES OF THE MIDDLE PLEISTOCENE.}

The earliest phase, corresponding with the earliest mid-Pleistocene of Europe, is probably at present unrecognized in America. Other early phases of the middle Pleistocene may be provisionally distinguished as follows: (1) The true European stag Cervus does not appear; (2) the Camelidæ, Equidæ, Tapiridæ, Edentata-Gravigrada, and Elephantidæ still survive; (3) many extinct species of modern genera and many surviving modern species appear.

Port Kennedy cave, Pennsylvania.-The Port Kennedy cave ${ }^{a}$ has yielded 54 species of mammals, 40 of which are now extinct. From an analysis of its fauna, Barnum Brown ${ }^{b}$ is inclined to place it in the early part of the mid-Pleistocene. The climate was apparently temperate. (1) It lacks the early Pleistocene genera Elephas and Camelus, but the latter has thus far not been found in eastern deposits at all. (2) Among surviving lower Pleistocene forms it includes (a) of the Machærodontinæ, 2 species; ( $b$ ) of the Edentata, 2 genera,

a Mercer, H. C., The bone cave at Port Kennedy, Pennsylvania: Jour. Acad. Nat. Sci. Philadelphia, vol. 11, pt. 2, 1899.

$b$ Brown, Barnum, The Conard fissure, a Pleistocene bone deposit in northern Arkansas: Mem. Am. Mus. Nat. Ilist., vol. 9, 1908, pp. 157-208. 
Megalonyx, Mylodon; (c) of the Perissodactyla, Equus, 2 species, Tapirus; $(d)$ of the Dicotylidæ, Mylohyus. (3) Among newly entering northern forms are: (a) Odocoileus; (b) Ursus, 2 species; (c) Erethizon (the first recorded appearance of the Hystricomorpha in North America).

(4) We note the absence of Bovidæ.

Twelvemile Creek, Kansas.-On the plains of western Kansas, in Logan County, on Twelvemile Creek, a tributary of Smoky Hill River, is a deposit formerly considered by Williston ${ }^{a}$ as of lower Pleistocene age, but now known to be of mid-Pleistocene age. In the blue-gray marl underlying the recent plains marl are recorded Elephas primigenius (? E. columbi), Platygonus compressus, and a number of specimens of Bison occidentalis (Lucas). Among Primates, Homo is indicated ${ }^{b}$ by the occurrence of an arrowhead certainly associated with the skeleton of Bison occidentalis and believed by Williston to be in situ.

\section{SUBSEQUENT PHASES OF THE MIDDLE PLEISTOCENE.}

HOMOTAXIS.

America.-Potter Creek cave, Shasta County, Cal.; Silver Lake, Oregon.

ENVIRONMENT.

Environmental conditions on the Pacific coast were quite different from those in the Middle and Eastern States: (1) All glaciation on the Pacific coast was comparatively late in the Pleistocene and of the alpine type (Sinclair). It is quite possible, therefore, that many types of mammals (elephants, mastodons, camels, bisons) survived in the comparatively mild climate of the Pacific coast after they had become extinct in more easterly regions.

\section{FAUNA.}

Potter Creek cave.-The very rich Potter Creek cave fauna is regarded by Merriam and Sinclair ${ }^{c}$ as a late phase of the middle Pleistocene, or even as late as the last quarter of the Pleistocene. It contains 37 genera and 49 species of mammals, of which 8 genera and 22 species are extinct, 3 are doubtfully extinct, and 21 are still existing. It is chiefly a forest fauna; forest types are numerous and plains types are lacking.

Positively we note the survival or presence of the edentates Megalonyx and Nototherium; also of Equus and Elephas. Among Artio-

\footnotetext{
$a$ Williston, S. W., The Pleistocene of Kansas: Univ. Geol. Survey Kansas, vol. 2, 1897, p. 300.

$b$ Williston, S. W., On the occurrence of an arrowhead with bones of an extinct bison: Trans. Intern. Congress of Americanists, 1902, p. 335.

$c$ Sinclair, W. J., A preliminary account of the exploration of the Potter Creek cave, Shasta County, Cal.: Science, n. s., vol. 17, No. 435, May 1, 1903, pp. 708-712. The exploration of the Potter Creek cave: Univ. California, Publ. Am. Arch. and Eth., vol. 2, No. 1, 1904, pp.1-27. New Mammalia from the Quaternary caves of California: Bull. Dept. Geology, Univ. California, vol. 4, 1905, pp. 145-161.
} 
dactyla-Cervidæ, the typical American deer Odocoileus is abundant. Negatively we note the absence or disappearance of PerissodactylaTapirus, of Carnivora-Machærodontinæ; these absences may have been due to local conditions; the machærodonts are frequently associated with a Plains fauna, as in the California asphaltum deposits. The nonappearance of the genus Cervus as well as of RodentiaHystricomorpha is significant.

A large number of new types appear. Among primates the presence of Homo is indicated, in the opinion of certain anthropologists (Putnam), by supposed bone implements; others (Merriam ${ }^{a}$ ) regard this evidence as inconclusive. Among Carnivora-Ursidæ, remains of Ursus and Arctotherium are very numerous; among Felidæ, Felis (a species of large size), Lynx; among Canidæ, Urocyon, Vulpes, Canis; among Mustelidæ, Taxidea, Mephitis, Spilogale, Putorius; among Procyonidæ, Bassariscus; among Rodentia, 17 existing species; among Artiodactyla, (a) Dicotylidæ, Platygonus (a doubtful determination); among (b) Cervidæ, Odocoileus; among (c) Bovidæ, Bison; among (d) Rupricaprinæ, Haploceras; among (e) Ovinæ, Euceratherium $^{b}$ (related to Ovibos); among ( $f$ ) Camelidæ, Camelus; among Edentata, Megalonyx (a forest and foothill edentate), 4 species; among Perissodactyla-Equidæ, Equus, 2 species; among Proboscidea, Mastodon (its first appearance, the species at present indeterminate), Elephas primigenius (? E. columbi).

Washtuckna Lake, Washington. - Of about the same age are the deposits of Washtuckna Lake, Washington, a forest, mountain, and open-country fauna, imperfectly known. Among CarnivoraMustelidæ, Taxidea; among Felidæ, Felis concolor, F. canadensis; among Edentata, Mylodon; among Perissodactyla-Equidæ, Equus; among Artiodactyla-Cervidæ, Alces, 2 species, Odocoileus, 1 species; among Camelidæ, Camelus, 3 species; among Rupricaprinæ, Haploceros.

Samwel cave, California.-In Samwel cave, Shasta County, Cal., is found (Furlong ${ }^{d}$ ) a fauna much more recent than that of the Potter Creek cave, including Preptoceras (with affinities to Ovibos and closer affinities to Euceratherium). Among Rodentia the Hystricomorpha appear; among Artiodactyla-Cervidæ, Odocoileus; among the absent or nonrecorded forms, Ursidæ, Arctotherium.

$a$ Merriam, J. C., Recent cave exploration in California: Am. Anthropologist, April-June, 1906, p. 221. $b$ Sinclair, W. J., and Furlong, E. L., Euceratherium, a new ungulate from the Quaternary caves of California: Bull. Dept. Geology, Univ. California, vol. 3, 1904, pp. 411-418.

c Matthew. W. D., List of the Pleistocene fauna from Hay Springs, Nebraska: Bull. Am. Mus. Nat. Hist., vol. 21, 1902, pp. 321-322.

$d$ Furlong, E. L., The exploration of Samwel cave: Am. Jour. Sci., 4th ser., vol. 22, Sept., 1906, pp. 235-247. 


\section{LATE PHASE OF THE MID-PLEISTOCENE.}

The Conard fissure of Newton County, Ark., ${ }^{a}$ contains a typical forest fauna that lived in a region with open glades similar to the present landscape. It is very rich in individual specimens. Of the 37 genera and 51 species of mammals represented, 4 genera and 24 species are now extinct. Twenty genera and 6 species which occur in the Port Kennedy cave are also found here. Of the surviving species many are now distinctly northern or boreal types, such as Microsorex, Mustela americana, Erethizon dorsatus, Cervus canadensis. There are also 7 species of amphibians and reptiles and 7 species of birds.

The Proboscidea, Edentata, Tapiridæ, and Camelidæ of the earlier Pleistocene faunæ have all disappeared or are not represented. Only Equus and a machærodont (Smilodontopsis) survive. There is no evidence of Homo.

Among Carnivora, (1) Ursidæ (Ursus) are numerous; (2) among Felidæ-Felinæ, Felis, subgenus Lynx; among Machærodontinæ, Smilodontopsis (Brown), a surviving saber-tooth; (3) among Canidæ, Canis, Vulpes, and Urocyon; (4) among Mustelidæ, Mephitis, Spilogale, Brachyprotoma (an extinct skunk, also found in the Port Kennedy cave fauna), Mustela, and Putorius; (5) among Procyonidæ, Procyon; among Insectivora, Blarina, Sorex, Microsorex, Scalops; among Cheiroptera, Vespertitio and Myotis; among Rodentia, Lepus, Microtus, Fiber, Neotoma, Reithrodontomys, Peromyscus, Castor, Geomys, Spermophilus, Tamias, Sciurus, Arctomys, and the hystricomorph Erethizon; among Artiodactyla-Dicotylidæ, Mylohyus; among Cervidæ, Odocoileus; among Equidæ, Equus (represented by a single tooth); among Bovidæ?, the aberrant musk ox, Symbos.

\section{CONCLUSION.}

The conclusion is that North America promises to give us a nearly complete and unbroken history of the Tertiary in certain ancient regions, which are, after all, comparatively restricted. The middle and upper Eocene is approaching solution, but the lower and basal Eocene still require additional surveys. The chief remaining gap is now in the Pliocene stratigraphy, which calls for very exact geologic sectioning and most careful systematic or faunistic comparisons.

Materials are at hand for an establishment of the Pleistocene sequence, which will be of the greatest aid to geologists. Here especially the paleontologist must work with the greatest caution in the identification and description of species. It would be easy by careless methods to separate two depositions which are actually closely similar in age.

$a$ Discovered in 1903 by Mr. Waldo Conard. The fauna was explored in 1903-4 and described by Barnum Brown in 1908: Mem. Am. Mus. Nat. Hist., vol. 9, 1908, pp. 157-208. 


\section{APPENDIX.}

\section{FAUNAL LISTS OंF THE TERTIARY MAMMALIA OF THE WEST.}

\section{By William Diller Matthew.}

BASAL EOCENE.

\begin{abstract}
First phase-Puerco.
Polymastodon zone.
\end{abstract}

1. San Juan basin, New Mexico.
SECOND PHASE-TORREJON.

Pantolambda zone.

1. San Juan basin, New Mexico.

2. Fort Union formation (in part), Montana.

\section{MULTITUBERCULATA.}

Plagiaulacide.

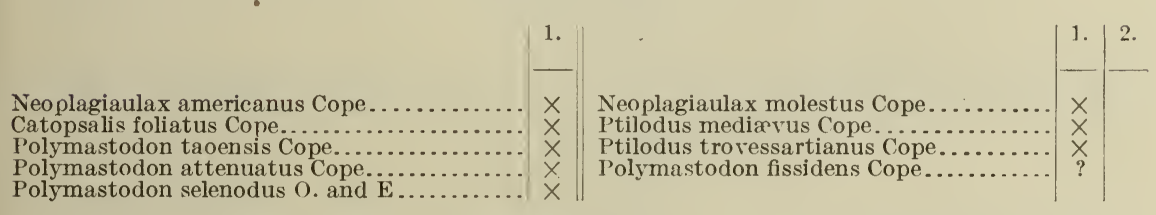

BOLODONTIDE.

|| Chirox plicatus Cope............... $\times$ |

\section{CRFODON'TA.}

\section{MIACIDE.}

| Didymictis haydenianus Cope.......... $\mid \times$ | ARCTOCYONIDE.

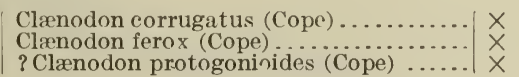

\section{MESONYCHIDA.}

Dissacus navajovius Cope $. . . \ldots \ldots \ldots . .$.

Dissacus saurognathus Wortman.........

TRIISODONTIDE.

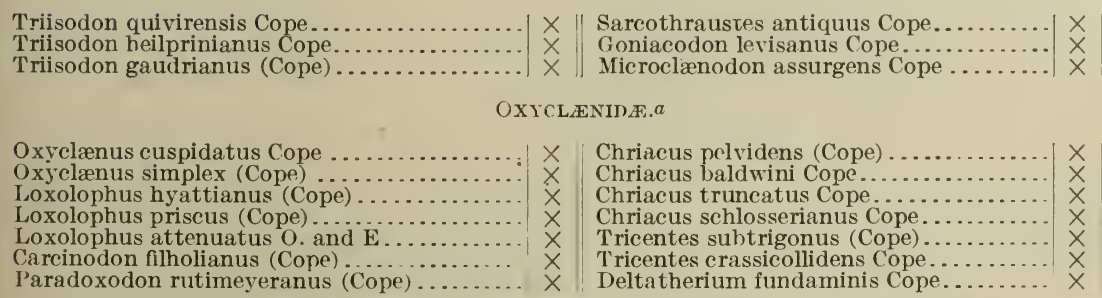

Loxolophus attenuatus $\mathrm{O}$. and

Paradoxodon rutimeyeranus (Cope)

$a$ Part or all of this family may be referable to the Insectivora, according to Wortman. 


\section{BASAL EOCENE-Continued.}

\section{INSECTIVORA.}

?HYOPSODONTIDE.

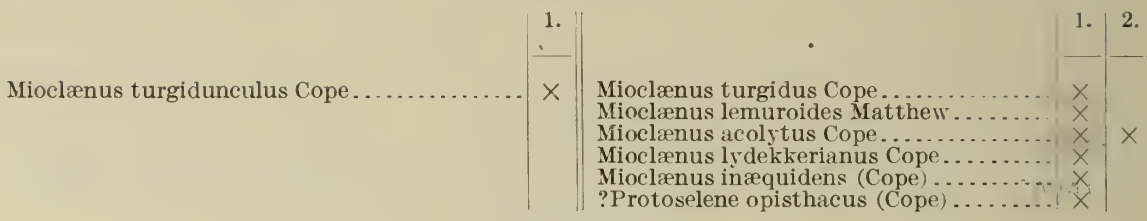

INCERTE SEDIS.

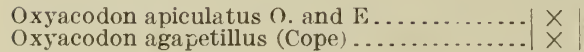

\section{Pantolestide.}

Pentacodon inversus Cope ............. $\times 1$

Mixodectide. $a$

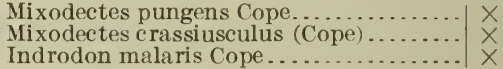

TANIODON'TA.

STYLINODONTIDE.

Wortmania otariidens Cope................ $\mid \times$, Psittacotherium multifragum Cope..... $|\times|$ CONORYCTIDE. $b$

Onychodectes tisonensis Cope. $x$
$x$

Conoryctes comma Cope. $|x|$

\section{CONDYLARTHRA.}

PHENACODONTIDE.

?Protogonodon pentacus Cope .............. $|\times| \mid$ Tetraclænodon puercensis (Cope) ...... $\times$. $\mid \times$ ?Protogonodon stenognathus Matthew....... $\times$ Tetraclænodon minor (Matthew) ........

\section{AMBLYPODA.}

PERIPTYCHIDE.c

Periptychus coarctatus Cope............... $X$

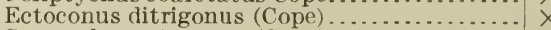
Conacodon entoconus (Cope) ................ Conacodon cophater (Cope) ................. Anisonchus gillianus Cope. Hemithlæus kowalerskianus Cope.
Periptychus carinidens Cope......... $\times$ Periptychus rhabdodon (Cope) .......... Haploconus lineatus Cope............ $x$ Haploconus corniculatus Cope........... Anisonchus sectorius Cope............. $\times$

\section{PANTOLAMBDIDE.}

Pantolambda bathmodon Cope....... $\times$

Pantolambda cavirictus Cope........... $\times$ $\times$

\section{IOWE R EOCENE.}

First Phase--Wasatch.

\section{Coryphodon zone.}

1. Typical Wasatch, Evanston, Wyoming.

2. Black Buttes, Washakie basin, IT yoming.

3. Bighorn Valley, Wyoming.

4. San Juan basin, New Mexico.
Second phase- Wind River.

\section{Lambdotherium and Bathyopsis zones.}

1. Wind River basin. Wyoming.

2. Lower Huerfano, Colorado.

\section{PRIMATES.}

NothaRCTIDE.

Pelycodus jarrovii Cope.

Pelycodus tutus Cope............

Pelycodus frugivorus Cope.

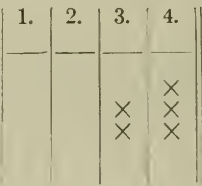

Pelycodus sp...................... Notharctus nunienus Cope..............

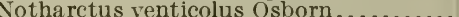

Notha retus palmeri Loomis............. Notharctus cingulatus Loomis............ $\mid \times$

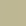




\section{LOWER EOCENE-Continued.}

\section{PRIMA'TES-Continued .}

ANAPTOMORPHIDE.
Anaptomorphus homunculus Cope............................. Loomis.
$-1.9-1$
1. $2 .|3| 4$.
1. 2.

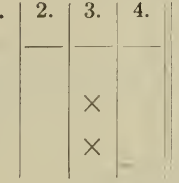
Anaptomorphus spierianus Cope.
Anaptomorphus abboti Loomis..
? Omomys ("Notharctus") minutus
Loomis........................ $\times$

\section{MICROSYOPIDE. $a$}
Cynodontomys latidens Cope ... Cynodontomys angulatus (Cope)
Microsyops scottianus Cope............... $|\times|$

\section{CARNIVORA (CREODON'TA).}

MIACIDE.

Didymictis protenus (Cope)..... Didymictis leptomylus Cope.... Viverravus ef. dawkinsianus (Cope) .....................

Miacis sp ...................

Uintacyon massetericus (Cope).

Vassacyon pronicrodon(W.and

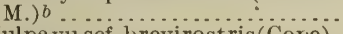

Vulparu scf. brevirostris(Cope).

Vulpavus sp .................

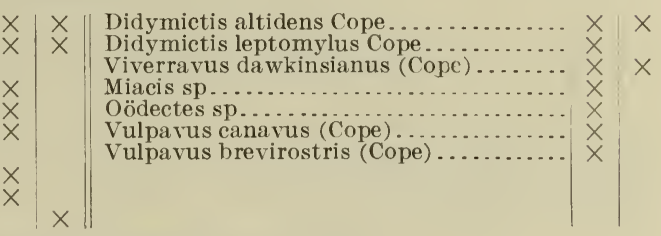

? ARCTOCYONIDE.

Anacodon ursidens Cope........ | | $\mid \times$

PALEONICTIDE (=AMBLOCTONIDE).

Palæonictis occidentalis Osborn.

Ambloctonus sinosus Cope......

Oxyæna lupina Cope.

Oxyæna forcipata Cope..........

Oxyæna morsitans Cope

$x \mid x \|$

OXYENIDE.

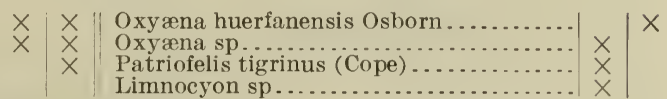

IY ENODONTIDE.

Sinopa viverrina (Cope)

Sinopa strenua (Cope) ............

Sinopa multicuspis (Cope).......

Sinopa hians (Cope)

Sinopa opisthotoma Matthew...

Pachyæna ossifraga Cope....... Pachyæna gigantea Osborn...... Pachyæna intermedia Wortman.

Hapalodectes leptognathus (Os-

born)d.

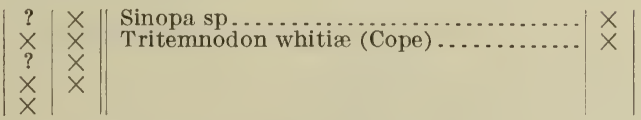

\section{MESONYCHIDA.}

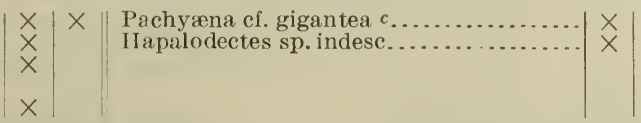

\section{INSECTIVORA.}

PANTOLESTIDE.

Palæosinopa veterrima Matthew

$|\times| \quad \|$ Palæosinopa didelphoides (Cope) $\ldots . . . .|\times|$

LEPTICTIDE.

Palæictops cf. bicuspis..........

Hyopsodus miticulus (Cope).... Hyopsodus lemoinianus Cope...

Hyopsodus powellianus Cope ...

Hyopsodus laticuneus (Cope)

Hyopsodus simplex Loomis.

$|X|$ || Palæictops bicuspis (Cope) $\ldots . . . . . . . \times 1$

HYOPSODONTIDE.

Diacodon alticuspis Cope.

Diacodon celatus Cope

Didelphodus absarokæ Cope $e$.

$a ?=$ Mixodectidæ (Insectivora)

$b$ Gen. nov. Type, Uintacyon promicrodon W. and M., 1899. Differs from Lintacyon in broad basinheel of lower carnassial and other characters.

c Auct. F. B. Loomis in lit.

d Gen.nov. Typc, Dissacus leptognathus, Osborn and Wortman, Buil. Am. Mus. Nat. Hist., vol. 4, p. 112 , fig. 10 .

$e$ Probably Insectivore, auct. J. L. Wortman.

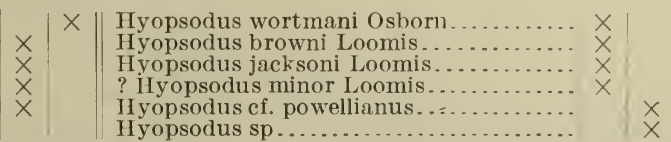

INCERTE SEDIS.

$\left|\begin{array}{l}x \\ \times\end{array}\right|$ "Peratherium" comstocki Core......... $|\times|$

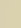




\section{LOWER EOCENE-Continued.}

\section{TILLODONTIA.}

? ANCHIPPODONTIDE.

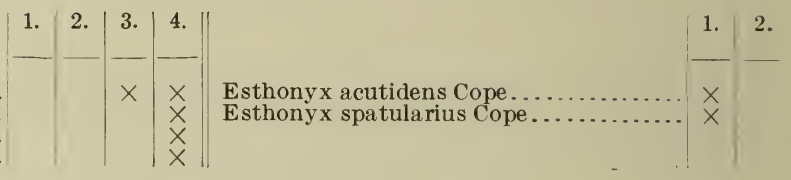

RODENTIA.

Esthonyx burmeisteri Cope.... Esthony $x$ acer Cope............. Esthonyx bisulcatus Cope.......

Esthonyx spatularius Cope.....

\section{ISCHYROMYIDE}

Paramys primævus Loomis..... Paramys quadratus Loomis .... Paramys atwateri Loomis ...... ? Sciuravus buccatus (Cope)....

Calamodon simplex Cope

Calamodon arcamoenus Co..... Calamodon novomehicanus Cope Ectoganus gliriformis Cope....

Dryptodon crassus Marsh.......

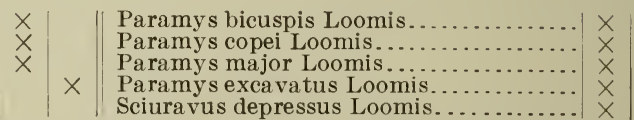

\section{TANIODONTA.}

STYLINODONTIDE.

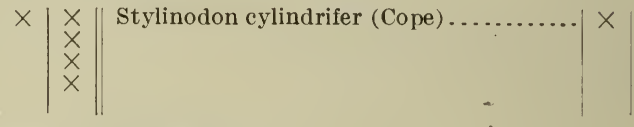

\section{CONDYLARTHRA.}

Phenacodontide.

Phenacodus primævus Cope..... $\times$

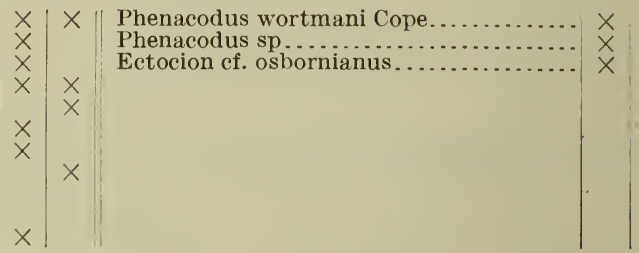

MENISCOTHERIIDE.

Phenacodus hemiconus Cope....

Phenacodus astutus (Cope) $a_{\ldots} .$.

Phenacodus flagrans (Cope).... .

Phenacodus brachypternus Cope

Phenacodus macropternus Cope.

?Phenacodus sulcatus Cope $b$...

Eohyus distans Marsh..........

Eohyus robustus Marsh..

Ectocion osbornianus Cope......

Meniscotherium

Cope.

terrærubræ

Meniscotherium chamense Cope.

Meniscotherium tapiacitis Cope..

\section{AMBLYPODA.}

\section{CORYPHODONTIDE.}

Coryphodon radians Cope....... $\times$ Coryphodon testis Cope......... Coryphodon lobatus Cope.

Coryphodon elephantopus Cope.

Coryphodon hamatus Marsh...

Coryphodon latidens Cope ......

Coryphodon curvicristis Cope...

Coryphodon armatus Cope......

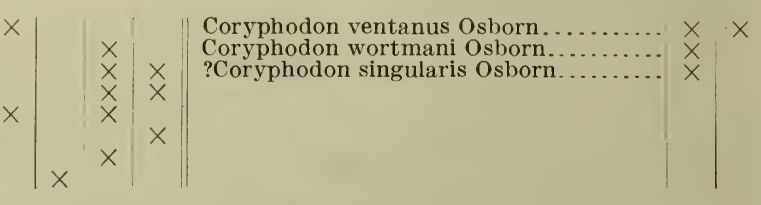

EOBASILEIDE (=UINTATHERIIDE).

Bathyopsis fissidens Cope............. $\mid \times 1$

\section{PERISSODACTYLA.}

LOPHIODONTIDE.

Heptodon posticus Cope........ Heptodon singularis (Cope) $b$...

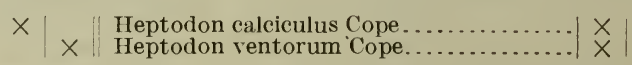
TAPIRID E.

Systemodon tapirinus (Cope)... Systemodon protapirinus Wort-

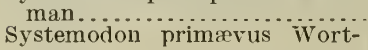

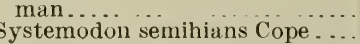


LOWER EOCENE-Continued.

- PERISSODACTYLA--Continued.

EQUIDE.

Eohippus pernix Marsh.........

Eohippus validus Marsh........

Eohippus vasacciensis (Cope)...

Eohippus index (Cope)

4.

Eohippus venticolus (Cope) ..

Eohppus index (Cope) ..........

Eohippus angustidens (Cope)

Eohippus cuspidatus (Cope) ...

Eohippus cristatus (Wortman)

Eohippus cristonensis (Cope)...

Eohippus montanus Wortnian.

Eohippus borealis Granger.

Eohippus resartus Granger......

TITANOTHERIIDE (=BRONTOTHERIIDE).

Lambdotherium popoagicum Cope...... $\times$ X $\times$

Eotitanops borealis (Cope) ............ $\times$

Eotitanops brownianus (Cope)............ $\times$

\section{ARTIODACTYLA.}

TRIGONOLESTIDE ( $=$ ? DICHOBUNIDE).

Trigonolestes brachystomus (Cope) .

Trigonolestes chacensis (Cope). Trigonolestes nuptus (Cope).... Trigonolestes metsiacus (Cope) . Helohyus etsagicus (Cope).....

\section{Parahyus vagus Marsh}

Parahyus aberrans Marsh.

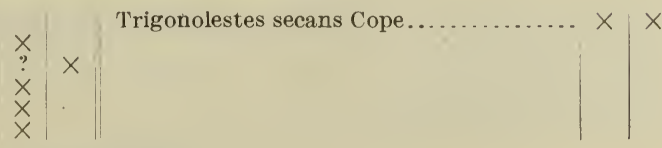

? ACHENODONTIDE.

\section{MIDDLE EOCENE.}

First phase-Bridger (lower part). Second phase-Bridger (Upper part).

\section{Orohippus zone.}

1. Lower Bridger (horizon B), Wyoming.

2. Upper Huerfano, Colorado.
Uintatherium zone.

1. Tpper Bridger (horizons $\mathrm{C}$ and $\mathrm{D}$ ), W yoming. 2. Washakie Basin, Wyoming.

\section{PRIMATES.}

Notharctid

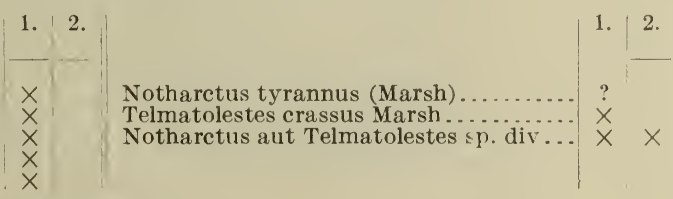

Pelycodus sp

Notharctus tenebrosus Leidy

Notharetus rostratus (Cope)

Telmatolestes crassus Marsh............ $\times$

Notharctus anceps (Marsh)

\section{ANAPTOMORPHIDE.}

Omomys carteri Leidy

Omomys pucillus (Marsh) .................

Omomys ameghini Wortman

Euryacodon lepidus Marsh.............

Anaptomorphus æmulus Cope.............

? Anaptomorphus sp.

? Smilodectes gracilis (Marsh) $a$.

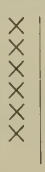

Memiacodon gracilis Marsh...

Hemiacodon pygmæus Wortm: $n . . . . . \times \times$

Washakius insignis Leidy ............. $\times$

Washakius sp..................... $\times$

\section{MICROSYOPIDE. $b$}

Microsyops elegans (Marsh) ............ Microsyops typus (Marsh) ................ $\times$ Microsyops sp......................... $\times$

a Incertæ sedis.
Microsyops annectens (Marsh) ......... $\times$ Microsyops schlosseri Wortman......... $\times \quad$ Microsyops sp.................... $\times$ $b ?=$ Mixodectidæ (Insectivora). 


\section{MIDDLE EOCENE-Continued.}

\section{CARNIVORA（CREODONTA）。}

MIACIDE.

\begin{tabular}{l|l|}
1. & 2. \\
\hline & \\
$x$ & \\
$x$ & \\
$x$ & \\
$x$ & \\
$x$ & \\
$?$ & \\
$?$ & \\
$x$ & \\
$x$ & \\
$x$ & \\
$x$ & \\
$x$ &
\end{tabular}

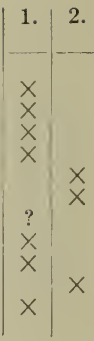

Viverravus gracilis Marsh.....

Viverravus minutus Wortman .........

Viverravus sp. indesc....................

Miacis parvivorus Cope ..................

Uintacyon vorax Leidy

Uintacyon edax Leidy.

? Uintacyon bathygnathus (Scett) ...........

Oödectes herpestoides Wortmian.

Oödectes sp. indesc.

Vulpavus palustris Marsh.......

Vulpavus sp. indesc..................

Vulpavus sp. indese

\section{OXYENIDE.}

Patriofelis ulta Leidy .

? Patriofelis coloradensis $a \times j, n j, \ldots .$.

Limnocyon verus Marsh

Thinocyon velox Marsh ...................

Thinocyon sp. indesc. .

Gen. et $\mathrm{sp}$. indesc.

x

Viverravus gracilis Marsh.......

iverravus minutus Wortman .......

Miacis sylvestris (Marsh) ................

Miacis washakius (Wortman) ..........

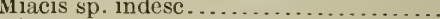

Uintacyon vorax Leidy ...............

Uintacyon sp. indesc..................

Uintacyon sp. indesc..................

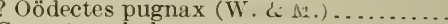

Gen. et sp. indesc..................... $\left.\right|^{x}$

Patriofelis ferox (Marsh) ..............

Limnocyon sp. indesc...................

Thinocyon medius Wortman.............

Thinocyon sp.indesc................ $\times$

\section{HYæNODONTIDE.}

Sinopa rapax Leidy

Sinopa pungens (Cope) ..................

Sinopa major Wortman..............

Sinopa minor Wortman................

Sinopa grangeri Matthew.

Tritemnodon agilis Marsh ................

$x$
$x$
$?$
$x$
$x$
$x$

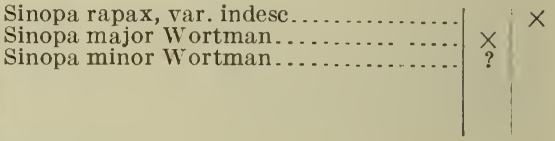

\section{MESONYCHIDE.} Mesonyx obtusidens Cope................
Harpagolestes macrocephalus wortman.

Synoplotherium lanius Cope $b$. $x \mid x$

\section{INSEC'TIVORA.}

APATEMyide.

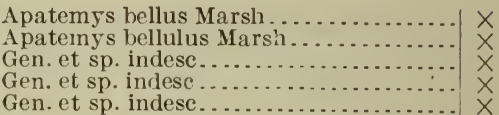

? TALPIDE.

Nyctilestes serotinus Marsh

Gen. et sp. indesc

Gen. et sp. indese.

Entomacodon angustidens Marsh .......
.......................

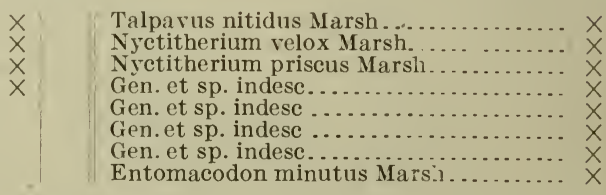

? Centetida.

Centetodon pulcher Marsh.............. $\times$

Centetodon altidens Marsh ................ $\times$

Centracodon delicatus Marsh............ $\times$

? LEPTICTIDE.

Antiacodon venustus Marsh $\quad \times$

Passalacodon littoralis Marsh ........... $\times$

Anisacodon elegans Marsh.............. $\times$

Gen. et sp. indesc . ...................

HYOPSODONTIDE.

Hyopsodus paulus Leidy

$\stackrel{x}{X}$

Hyopsodus sp. indesc

Hyopsodus sp. indesc....

Hyopsodus marshi Osbo.n................

Pantolestide.

Pantolestes longicaudus Cope

Pantolestes sp. indesc.

Pantolestes sp. indesc

Pantolestes cf. longicaudus................. $\times$

a "P. ulta Leidy," Osborn, Bull. Am. Ius. Nat. Hist., 1897, p. 256; idem, 1900, p. 278, fig. 8 . Not $P$. ulta of Leidy.

$b$ Including Dromocyon vorax Marsh. 
MIDDLE EOCENE-Continued.

TILLODONTIA.

ANCHIPPODONTIDE.

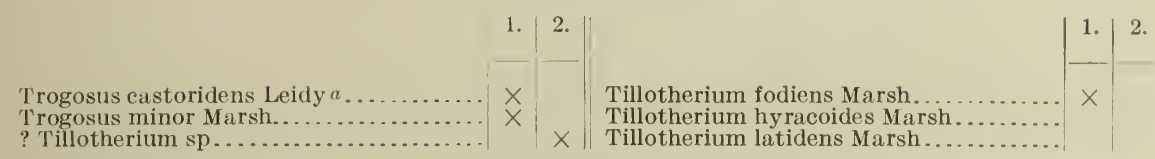

\section{RODENTIA.}

ISCHYROMYID A.

Paramys delicatus Ieidy.

Paramys delicatior Leidy.

Paramys delicatissimus Leidy...

Paramys sp. div....

Pseudotomus hians Cope

Pseudotomus robustus (Ma...

Pseudotomus superbus (O., S., and S.).

Pseudotomus sp. div.

Sciuravus nitidus Marsh

Sciuravus undans Marsh. .......

Sciuravus parvidens Marsh...
Sciuravus minimus (Leidy).

Scluravus sp. div .................. $\times$

Tillomys parvus Marsh...............

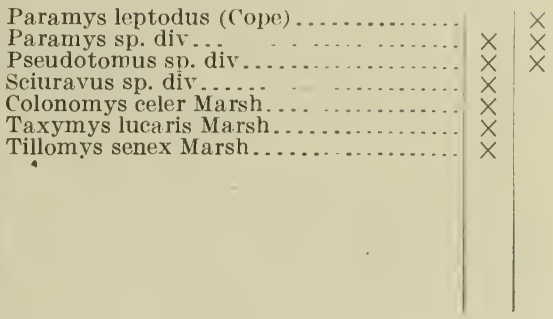

\section{TANIODONTA.}

STYLINODONTIDE.

Stylinodon mirus Marsh............ . ? I

\section{EDEN'TA'TA.}

METACHEIROMYIDA.

Metacheiromys marshi Wortman.

Metacheiromys dasypus Osborn...

Metacheiromys tatusia Osborn...

Metacheiromys sp.

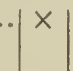

AMBLYPODA.

FOBASILEIDA (= UINTATHERIIDE).

? Uintatherium sp

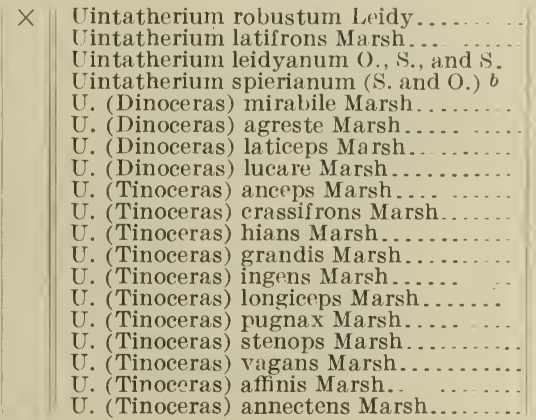

\section{PERISSODACTYLA.}

HYRACODONTIDE.

Hyrachyus agrarius Leidy.

Hyrachyus sp. div.......

? Hyrachyus bairdianus (Marsh)

Hyrachyus paradoxus O., S., and

Colonoceras agrestis Marsh...
Hyrachyus eximius Leidy ...

$\times \quad$ Hyrachyus intermedius $0 . . . . .$. and $\mathrm{S}$.

Hyrachyus crassidens O., S., and S

Hyrachyus princeps Marsh...

Hyrachyus imperialis O., S., and S....

Hyrachyus sp. div $: . . . . . . . . . . . . .$.

Triplopus cubitalis cope.

"Triplopus" amarorum Cope............ 
MIDDLE EOCENE-Continued.

PERISSODACTYLA-Continued.

LOPHIODONTIDE.

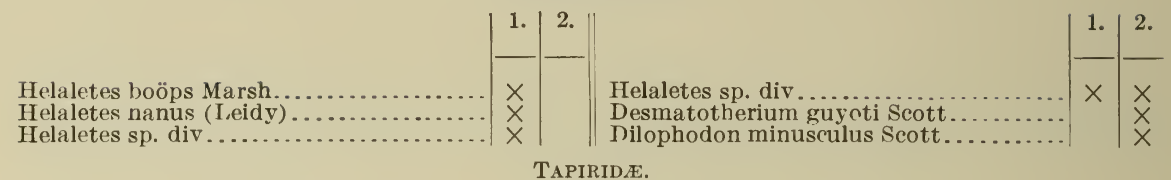

TAPIRIDE.

? Isectolophus modestus (Leidy)....... $|\times| \quad \|$ Isectolophus latidens (S. and O.)....... $|\times|$ EQUTDA.

Orohippus pumilus (Marsh)

Orohippus sylvaticus (Leidy)

Orohippus agilis Marsh.................. $\times$

Orohippus uintanus (Marsh) $\ldots . . . . . . . . . \times$

Orohippus ballardi (Marsh) .............. $\times$

Orohippus procyoninus (Cope) ...........

Orohippus major Marsh.............. $X$

Orohippus cinctus (Cope)............. $X$

Orohippus oshornianus (Cope).............

\section{TITANOTHERIIDE (=BRONTOTHERIIDE) $a$}

Palæosyops paludosus Leidy............ $\times$ Palæosyops major Leidy.............. $\times$ Palæosyops fontinalis cope........... $\times$ Limnohyops laticeps Marsh............. $\times$ Palæosyopinæ sp. div................... $\times$

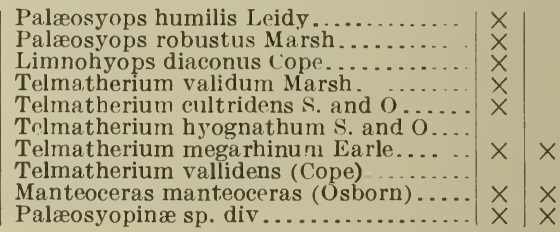

ARTIODACTYLA.

HOMACODONTIDE (= DICHOBUNIDÆ). $b$

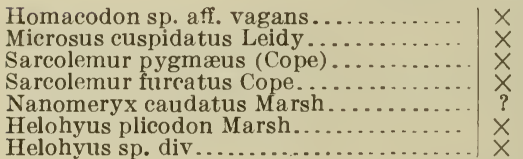

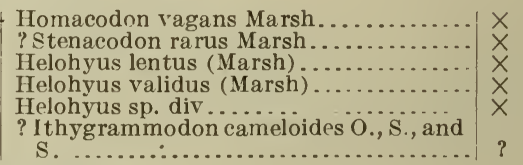

\section{UPPER EOCENE.}

First phase.

\section{Eobasileus zone.}

1. Washakie Basin, Wyoming (upper beds).

2. Uinta Basin, Utah (horizons $\Lambda$ and $B$ ).

3. ? Sage Creek, Montana.

4. ? Uppermost Bridger (horizon E), Wyoming.
Second phase-True Uinta.

\section{Diplacodon zone.}

1. Uinta Basin, Utah (horizon C).

PRIMATES.

NOTHARCTIDE.

Notharetus uintensis (Osborn).

$$
\left|\frac{2 .}{\times}\right| \frac{3 .}{?}\left|\frac{4}{?}\right| \mid
$$

\section{CARNIVORA (CREODONTA).}

MIACIDE.

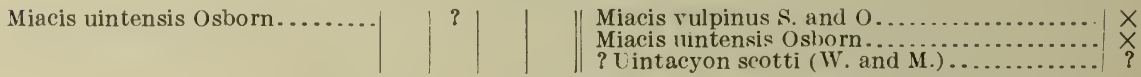
OXYANID死.

Oxyænodon dysodus Matthew .. $|\times| \times|\quad| \begin{aligned} & \text { Oxyænodon dysclerus Hay.................. } \\ & \text { Limnocyon sp. indesc . }\end{aligned} \mid \times$ MESONYCHIDE.

Harpagolestes uintensis (S. and $|\quad| \quad|\quad|$ Harpagolestes uintensis (S. and O.)........ ?

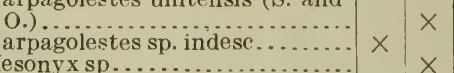

$a$ The Eocene titanotheres will be revised and the list of genera and species considerably extended in Professor Osborn's forthcoming monograph on the family.

$b$ See Stehlin, Säugethiere des schweizerischen Eocäns, IV. Th., Abhandl. Schw. pal. Ges., vol. 23, 1906 , p. 669, for inclusion of Homacodon and related genera in the Dichobunidæ. The reference of Microsus and Sarcolemur to t:is group is based on comparison with Homacodon. 
UPPER EOCENE-Continued.

CARNIVORA (FISSIPEDIA).

Canide.

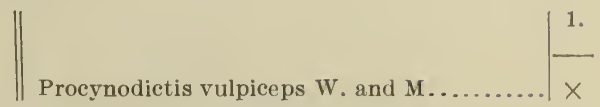

\section{INSECTIVORA.}

HYOPSODONTIDE.

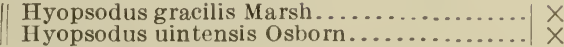

RODENTIA.

ISCHYROMYIDE.

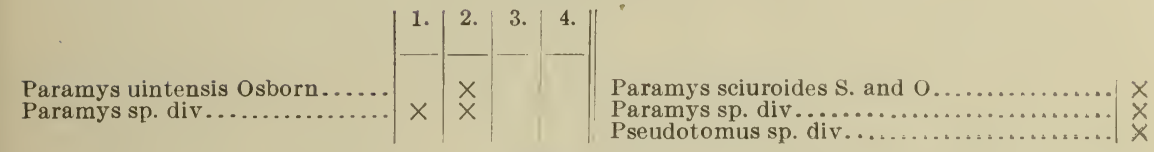

? GEOMYIDE.

If Protoptychus hatcheri Scott.............. X

AMBLYPODA.

EOBASILEIDE.

Eobasileus cornutus Cope.......

Eobasileus furcatus Cope.........

Eobasileus pressicornis Cope ....

Eobasileus galeatus (Cope).......

Eobasileus sp. div.

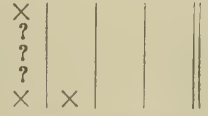

\section{PERISSODACTYLA.}

IIYRACODONTIDE.

Hyrachyus priscus Douglass.... $\left.\right|_{\times} \times\left.\right|^{X} \quad$ || Triplopus obliquidens (S. and O.)......... $\mid \times$ Hyrachyus sp. div.............. $\times$

Amynodon anticuus (S. and O.).

"Amynodon sp....................

nodon)

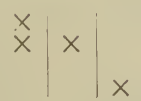

Amynodon advenus Marsh.

LOPHIODONTIDE.

"Heptodon"? sp.(=? Helaletes).

$|\times|$

\section{TAPIRIDE.}

i) Isectolophus annectens (S. and O.)........ $\times$ EQUIDA.

Epihippus uintensis Marsh $\ldots \ldots \ldots \ldots \ldots \ldots \ldots$
Epihippus graciiis Marsh $\ldots \ldots \ldots \ldots \ldots \ldots \ldots$

TITANOTHERIIDE (=BRONTOTHERIIDE). $a$

Dolichorhinus cornutus (Osborn)

Dolichorhinus sp...............

Telmatherium diploconum Os-

born........................

Telmatherium sp. div............

Manteoceras sp. div.

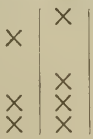

Diplacodon elatus Marsh

Diplacodon emarginatus Hatcher...............

Diplacodon sp........................... $x$

Telmatherium sp. div ............. $X$

? Manteoceras ulrimus (Osborn) .............. $X$

Manteoceras sp. div......................

\section{ARTIODACTYLA.}

ACHENODONTIDE.

Achænodon insolens Cope........

Achænodon robustus Oshorn..... ?

$\begin{aligned} & \text { Achænodon uintensis (Osborn)... } \\ & \text { Achænodon sp.................. }\end{aligned} \times \times$

? DICHOBUNIDE. $b$

$\mid \begin{aligned} & \text { Bunomeryx montanus Wortman............. } \\ & \text { Bunomeryx elegans Wortman............ }\end{aligned}$

$a$ See footnote $a$ on p. 98 .

$b$ Auct. Stehlin. See footnote $b$ on p. 98 . 


\section{UPPER EOCENE-Contintied.}

\section{ARTIODA CTYLA-Continued:}

Camelide or Hypertragulide.

Leptotragulus proavus $\mathrm{S}$. and $\mathrm{O}$ ?Leptotragulus sp.

Leptoreodon? marshi wortman.

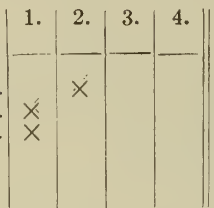

Leptotragulus proavus $\mathrm{S}$. and $0 \ldots \ldots \ldots \ldots \times$ Leptotragulus lævis (Marsh) ................ $\times$ Leptotragulus sulcatus (Marsh) ........... $X$ Protylopus petersoni Wortman............ $\times$ Camelomeryx longiceps Scott............. $\times$ Oromeryx plicatus Marsh................ $\times$

OREODONTIDE.

Protoreodon parvus S. and $0 \ldots \ldots \ldots \ldots \times$ Protoreodon pumilus (Marsh) .............. $\times$ Protoreodon paradoxicus (Scott) .......... $\times$ Protoreodon minor Scott.................. $\times$ Protagriochnerus annectens $\operatorname{scott} . . . . . . . . . . \times$

Hyomeryx breviceps Marsh................ $\times$

\section{Range of Eocene genera.}

[The figures show the number of known species in each gentis. Crosses indicate that the presence of the genus is recorded but no species have been described.]

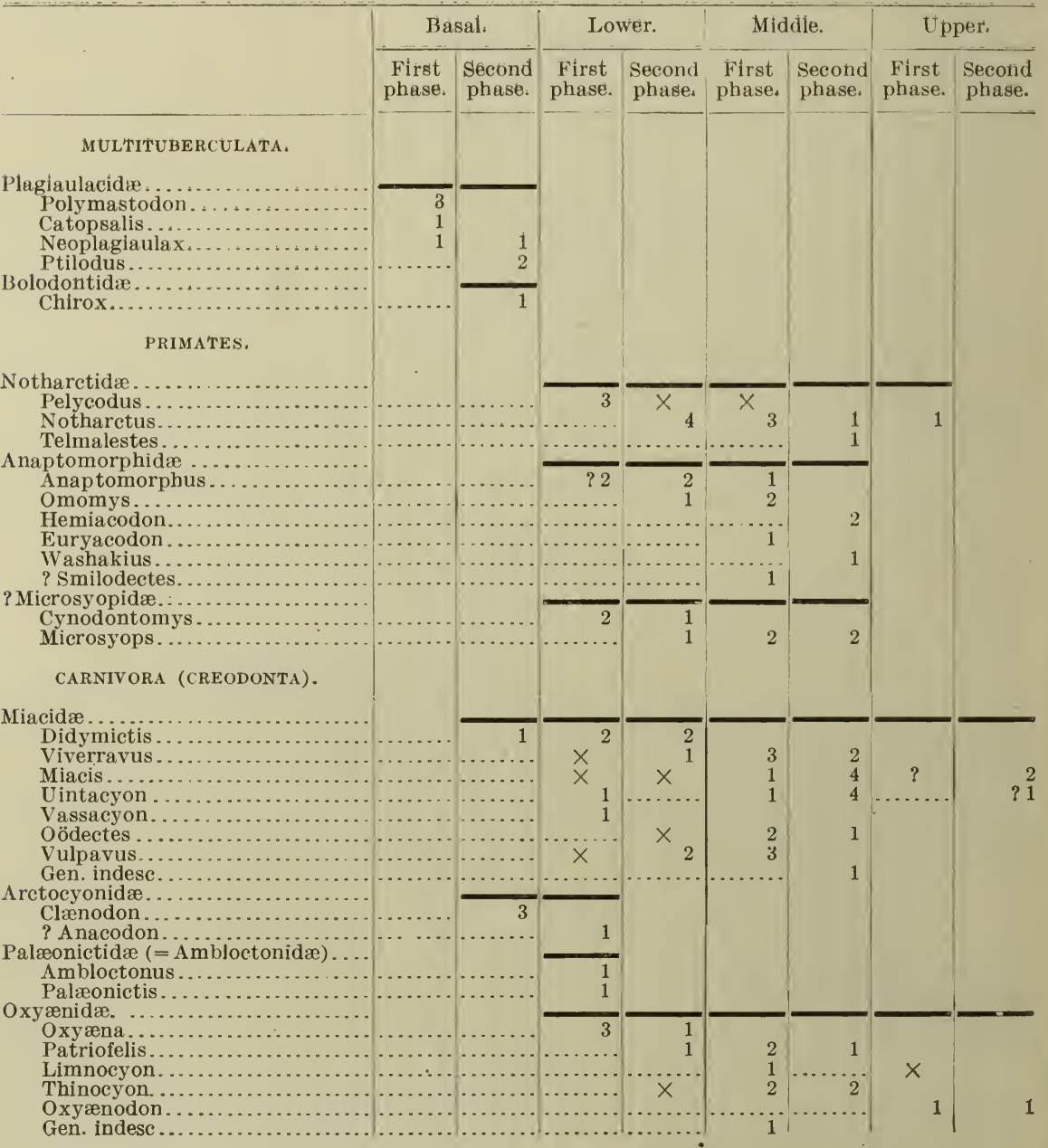


Range of Eocene genera-Continued.

CARNIVORA (CREODONTA) - cont'd.

Hyænodontidæ (Proviverrinæ) ... . Sinopa.

Tritem .......................

Mesonychidæ...

Dissacus.

Pachyæna .

Mesonyx.

Synoplotherium

Harpagolestes

Hapalodectes

Triisodontidæ

Triisodon.

Sarcothraustes.

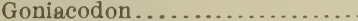

Microclænodon

Oxyclænidæ...

Oxyclænus.

Protochriacus $=$ Loxolophus.

Carcinodon...

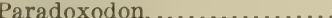

Chriacus.

Tricentes..........................

Deltatherium.

\section{INSECTIVORA.}

Pantolestidæ.

Pentacodon.

Palæosinopa.

Pantolestes.

Hyopsodontidæ

Mioclænus...

?Protoselene

Hyopsodus. .

Leptictidæ.

- Antiatons.

Passalacodon.

Anisacodon.

Gen. indesc

Apatemyidæ

Apatemys.

Gen. indese

? Talpidæ

Talpavus.

Nyctitherium

Nyctilestes

Gen. indesc

Gen. indesc.

Gen. indesc .

Gen. indesc

Entomacodon

? Centetidx

Centetodon

Centracodon.

Mixodectidæ.

Iixodectes

Olbodotes

Incertæ sedis

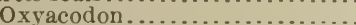

Diacodon

Didelphodus.

\section{TILLODONTIA.}

?Anchippodontidæ.

Esthony

Trogosus....

Tillotherium

\section{RODENTIA.}

Ischyromyidæ.

Paramys...

Pseudotomus.

Sciura vus.

......................

Taxymys

Tillomys.

?Geomyidæ.

Protoptychus.

$$
\text { . }
$$

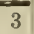

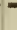

2

3

1

1

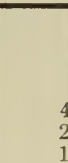

..........

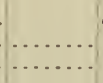

1

2

\begin{tabular}{|c|c|c|c|c|c|c|c|}
\hline \multicolumn{2}{|c|}{ Basal. } & \multicolumn{2}{|c|}{ Lower. } & \multicolumn{2}{|c|}{ Middle. } & \multicolumn{2}{|c|}{ Upper. } \\
\hline $\begin{array}{l}\text { First } \\
\text { phase. }\end{array}$ & $\begin{array}{l}\text { Second } \\
\text { phase. }\end{array}$ & $\begin{array}{l}\text { First } \\
\text { phase. }\end{array}$ & $\begin{array}{l}\text { Second } \\
\text { phase. }\end{array}$ & $\begin{array}{c}\text { First } \\
\text { phase. }\end{array}$ & $\begin{array}{l}\text { Second } \\
\text { phase. }\end{array}$ & $\begin{array}{c}\text { First } \\
\text { phase. }\end{array}$ & $\begin{array}{l}\text { Second } \\
\text { phase. }\end{array}$ \\
\hline
\end{tabular}

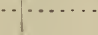

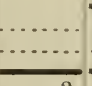
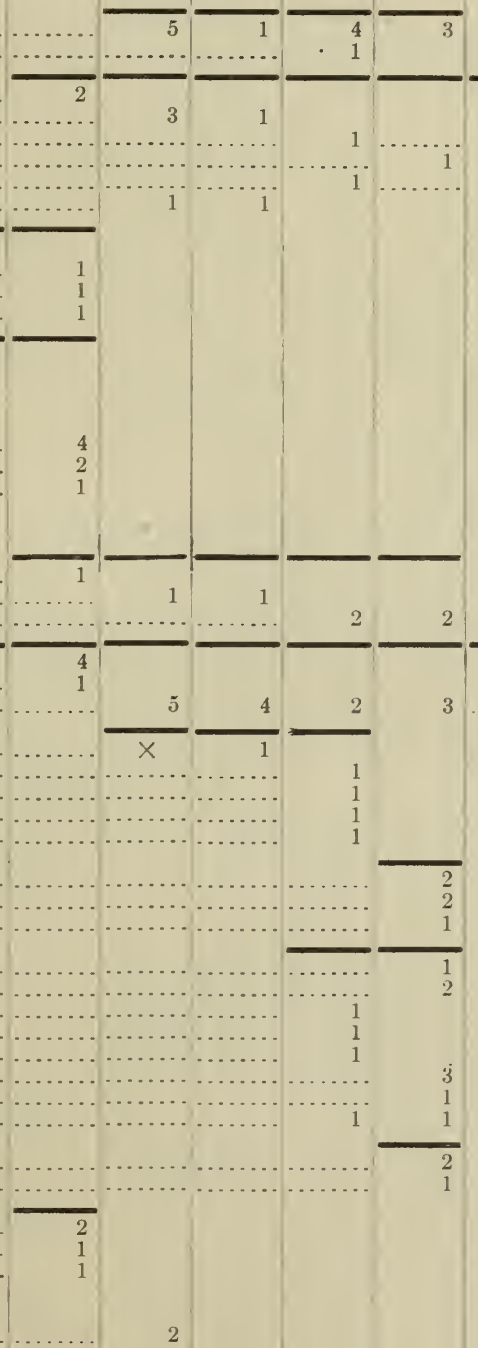

2

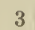

\section{2}


Range of Eocene genera-Continued,

TENIODONTA.

Stylinodontidæ,

Wortmania,

Psittacotherium

Calamodon (incl. Dryptodon). Ectoganus...

Stylinodon......................

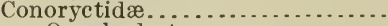

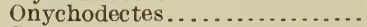

Conoryctes.

EDENTATA.

Metacheiromyidæ:

Metacheiromys

AMBLYPODA.

Periptychidæ

Periptychus

Ectoconus

Conacodon....................

Hemithlæus ......................

Haploconus

Anisonchus...............................

Pantolambdidæ

Pantolambda..................

Coryphodontidæ

Coryphodon

Eobasileidæ.

Bathyopsis.

Uintatherium $a . . . . . . . . . . . . . . .$.

Eobasileus

CONDYLARTHRA.

Phenacodontidæ

Protogonodon.

Euprotogonia (

Phenacodus (=Tetraclænodon)

Ectocion

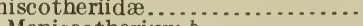

Meniscotherium $b$

PERISSODACTYLA.

Hyracodontidæ.

作

Colonoceras . . . . . . . . . . . . . .

Triplopus...

Amynodontidæ

Amynodon

Lophiodontidx.

Heptodon.

作

Desmatotherium

Tapiridæ.

Systemodon.

Isectolophus.

Equidæ.

Eohippus $d$

Orohippus $e$

Epihippus.

Titanotheriidæ

Lambdotherium .

Eotitanops.

Palæosyops

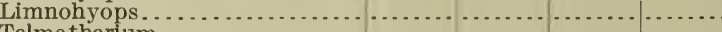

Telmatherium

Manteoceras..

Diplacodon...

\begin{tabular}{|c|c|c|c|c|c|c|c|}
\hline \multicolumn{2}{|c|}{ Basal. } & \multicolumn{2}{|c|}{ Lower. } & \multicolumn{2}{|c|}{ Middle. } & \multicolumn{2}{|c|}{ Upper. } \\
\hline $\begin{array}{l}\text { First } \\
\text { phase. }\end{array}$ & $\begin{array}{l}\text { Second } \\
\text { phase. }\end{array}$ & $\begin{array}{c}\text { First } \\
\text { phase. }\end{array}$ & $\begin{array}{l}\text { Second } \\
\text { phase. }\end{array}$ & $\begin{array}{l}\text { First } \\
\text { phase. }\end{array}$ & $\begin{array}{c}\text { Second } \\
\text { phase. }\end{array}$ & $\begin{array}{c}\text { First } \\
\text { phase. }\end{array}$ & $\begin{array}{l}\text { Second } \\
\text { phase. }\end{array}$ \\
\hline
\end{tabular}

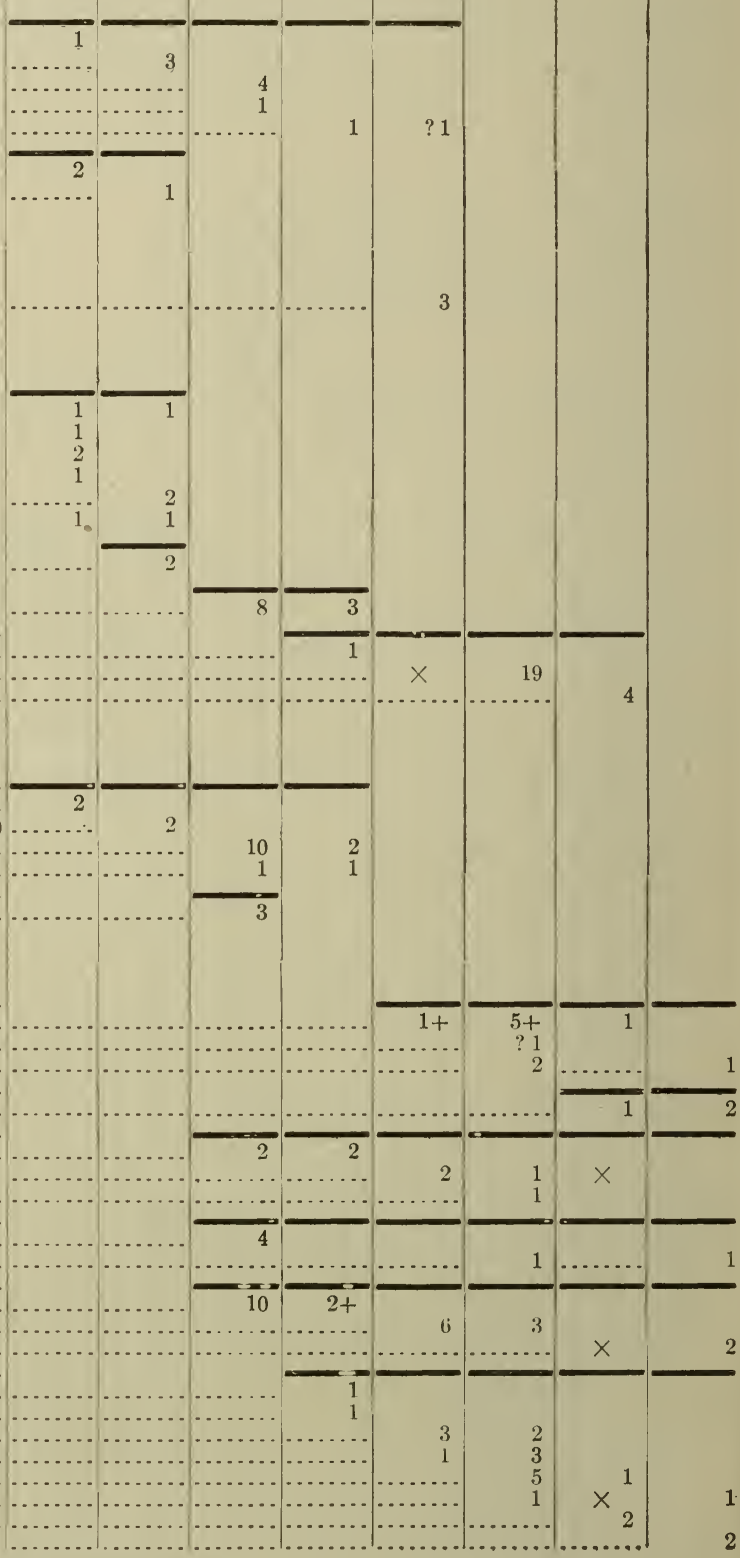

$a$ Including Dinoceras and Tinoceras.

$b$ Including Hyracops.

$c$ Including Dilophodon.

a Including Protorohippus.

e Including Orotherium, Helohippus, Oligotomus, and Helotherium. 
Range of Eocene genera-Continued.

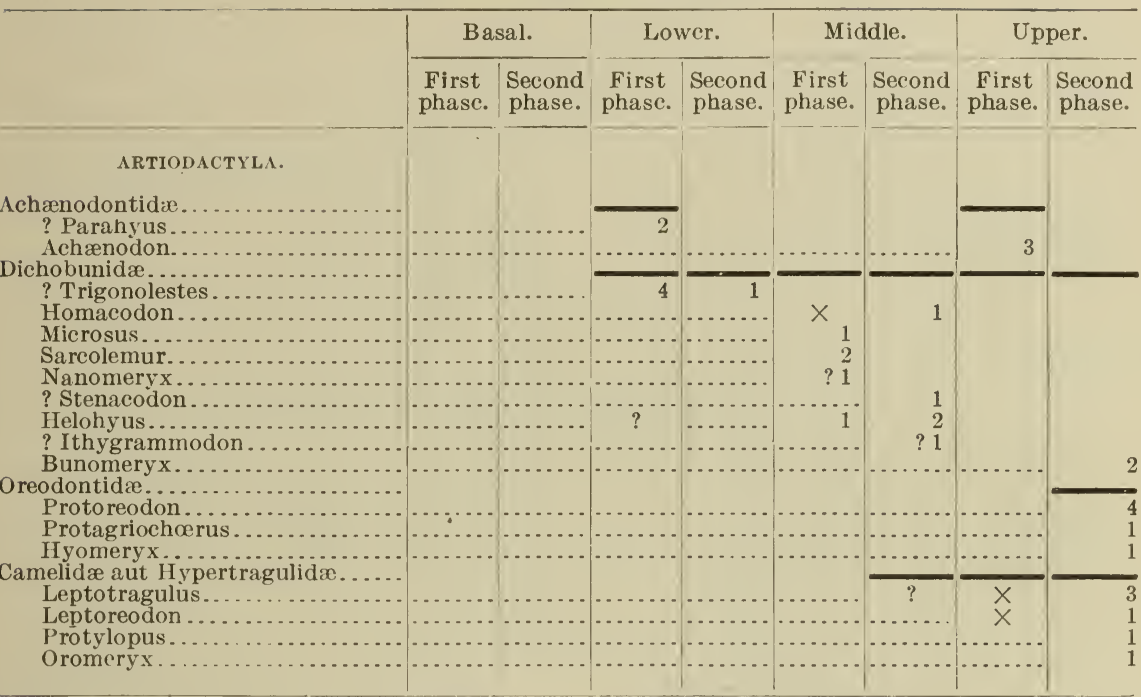

\section{LOWER OLIGOCENE.}

\section{Chadron (White River group).}

Titanotherium zone.

1. Chadron, South Dakota and adjoining parts of Nebraska and Wyoming.

2. Horsetail Creek, northeastern Colorado.

3. Pipestone Creek, Thompson Creek, and other localities in Montana.

4. Swift Current Creek, Canada.

\section{MARSUPIALIA.}

DIDELPHYIDE.

Peratherium titanelix Matthew.

CARNIVORA DONTA).

HYANODONTIDE.

? Pseudopterodon minutus (Douglass) a............... Hemipsalodon grand is Cope... Hyænodon sp.

\section{CARNIVORA (FISSI- PEDIA).}

\section{CANIDE.}

Daphænus dodgei Scott

Daphrenus sp. Cynodictis paterculus Matthew Cynodictis sp

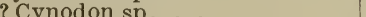

\section{MUSTELIDE.}

Bunælurus infelix Matthew .

\section{FELIDEE}

Dinictis fortis Adams......... Dinictis sp.

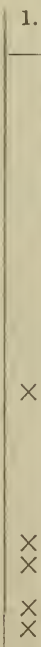

1. 2. $3 . \mid 4$.

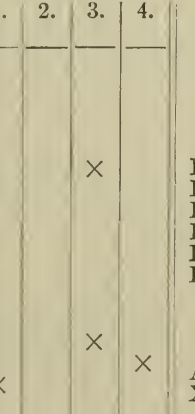

INSECTIVORA.

LEPTICTIDE.

Ictops acutidens Douglass. Ictops thomsoni Matthew. ctops montanus Douglas ctops intermedius Douglass... Ictops tenuis Douglass.......

Ietops major Douglass........

\section{? CHRYSOCHLORID $A$}

Apternodus mediævus Matthew Xenotherium unicum Douglass .

FAM. INDET

Micropternodus borealis Mat-

\section{RODENTIA.}

SCIURIDÆ.

Prosciurus vetustus Matthew Prosciurus jeffersoni Douglass

\section{CASTORIDE.}

Cylind rodon fontis Douglass...

Cylind rodon fontis Douglass...

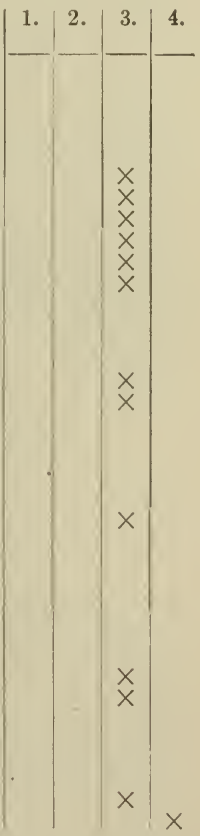

$x$

$a$ The type of this species is at present indeterminate. The reference to Pseudopterodon is based on the specimen figured by Matthew, 1903.

$b$ Auct. L. M. L,ambe in lit. 
LOWER OLIGOCENE-Continued.

1. 2. $3 . \mid 4$.

RODENTTIA-Continued.

ISCHYROMYIDE.

Ischyromys reterior Matthew.. Gymnoptrchus (=Adjidaumo) minutus (Douglass) ......... Grmnoptychus (=Adịiaumo) minımus Matthew............

LEPORIDE.

Palæolagus temnodon Douglass. Palæolagus brachyodon Iratthew.

PERISSODACTYLA.

HYRACODONTIDE.

Hyracodon priscidens Lambe... Hyracodon $\mathrm{sp} . . . . . . . . . . . . .$.

AMFNODONTIDE.

Metamynodon sp.

RHINOCEROTIDE.

Trigonias osborni.............. Trigonlas sp.................. I.eptaceratherium trigonodum. Cænopus (=Subhrracodon) $\mathrm{sp}$.

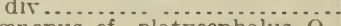

Cænopus cf. platycephalus O. and II $\ldots . . . \ldots \ldots \ldots . . . . .$.

Cænopus mitis Cope.............

LOPHIODONTIDE.

Colodon (=Mesotapirus) occidentalis Leidy

EQTIDE.

Mesohippus proteulophus Os-

born.......................

Mesohippus hypostrlus.........

Mesohippus celer Marsh........

Mesohippus montanensis Os-

born...............................

Mesohippus precocidens Lambe.

Mesohippus propinquus Lambe.

Mesohippus stenolophus Lambe Mesohippus planidens Lambe.. II e s o h i p p us assiniboiensis Lambe.

Mesohippus ? brachystylus Osborn......................

? CHALICOTHERIIDE.

"Chalicotherium" bilobatum Cope $a$.

TITAXOTHERIIDE (= BRONTOTHERIIDE).

Titanotherium prouti Leidy.... $\times$

Titanotherium helocerus (Cope)

Titanotherium trig on oceras

(Cope

(cope......................

Megacerops coloradensis (Leidy)

Megacerops dispar (Marsh).....

Megacerops angustigenis Cope.

Megacerops selwynianus (Cope).

Megacerops tichoceras (S.and O.) ..........................

Megacerops robustus (Marsh)..

Megacerops brachycephalus Osborn

X

$x$

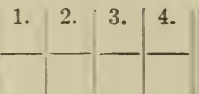

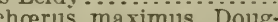

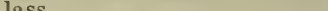

Agriochoerus mininius Doug-

lass.......................

Agriochœerus sp..............

\section{HYPERTRAGLLIDE.}

Trigenicus socialis Douglass... ? T rigenicus mammifer Cope... Leptomeryx esulcatus Cope....

Leptomeryx sp. dir...........

Heteromerrx dispar Matthew...

? Heteromerrx transversus

Cope) - .

CAMELIDE.

? Leptotragulus profectus Matthew.

a Generic reference incorrect; family reference very questionable. 


\section{MIDDLE OLIGOCENE.}

\section{Brule (lower part) (White River group).}

\section{Oreodon zone.}

1. Lower Brule, South Dakota and adjoining parts of Nebraska and Wyoming.

2. Cedar Creek, northeastern Colorado.

3. Scattered exposures in southwestern Montana.

\begin{abstract}
MARSUPIALIA.
DIDELPHY'ID.E.

Peratherium fugax (Cope) ........... Peratherium tricuspis (Cope) ..... Peratherium scalare (Cope ........ Peratherium marginale (Cope)

Peratherium alternans (Cope)..... Peratherium pygmæum (Scot $t)$.
\end{abstract} Peratherium huntii (Cope.

\section{CARNIVORA (CREO- DON'TA).}

HY ENODONTID.E.

Hyænodon horridus Leidy .......... Hyænodon cruentus Leidy ........... Hyænodon crucians Leid $5 . . . . . .$. . Hyænodon paucidens $\mathrm{O}$. and $\mathrm{W}$.... Hyænodon leptocephalus S. and O.. Hyænodon mustelinus Scott........ Hyænodon montanus Douglass.....

\section{CARNIVORA（FISSI - PEDIA).}

\section{CANID.玉.}

Daphœnus retus Leid $5 . . . . . . . . .$.

Daphœenus hartshornianus (Cope)... Daphœenus felinus Scott Daphœnus nebrascensis (Hatcher) $a$. Daphoenus inflatus (Hatcher).

Cynodictis gregarius (Cope) ......... Cynodictis lippincottianus (Cope)...

\section{MCSTELID.玉.}

Bunælurus lagophagus Cope....... ? Oligobunis sp.....................

FELIDE.

Dinictis felina Leid $y . . . . . . . . . . .$. Dinictis squalidens (Cope) .......... Dinictis paucidens Riggs

Iloplophoneus primærus (Leidr).... Hoplophoneus occidentalis (Leîd $y$ ) Hoplophoneus oreodontis Cope.... Hoplophoneus sp. (transitional to Eusmilus)

\section{INSECTIVORA.}

\section{ERINACEIDE.}

Proterix loomisi Matthew

\section{LEPTICTIDE.}

Leptictis haydeni Leidy

Ictops dakotensis Leidy

Ictops bullatus Matthew...........

ctops porcinus (Leidy) ..............

Mesodectes caniculus Cope

\section{SORICIDE.}

Protosorex crassus Scott

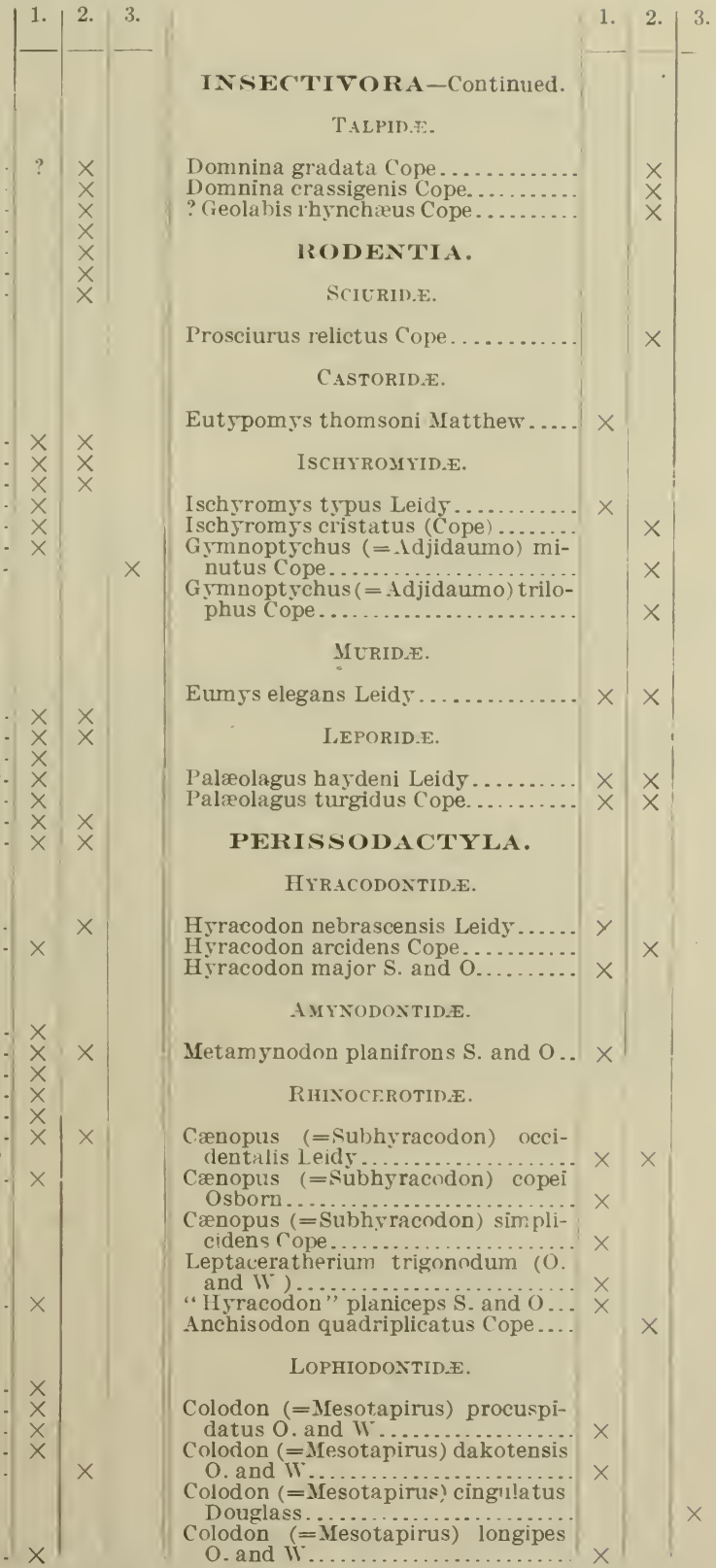

a Mr. Hatcher regarded this and the following species as types of distinct genera. As all the distinctive characters are functions either of the size of the species or the wear of the teeth they can hardly be regarded as of generic importance. D. nebrascensis is in fact very closely related to $D$. felinus and $D$. vetus, and $D$. inflatus to $D$. hartshornianus. 


\section{MIDDLE OLIGOCENE-Continued.}

PERISSODACTYLA-Con,

TAPIRIDE,

Protapirus simplex Wortman and Earle........................ $\times$

\section{EQUIDE.}

Mesohippus bairdii Leidy...

Mesohippus obliquidens Osbo

Mesohippus eulophus Osborn.........

Mesohippus exoletus (Cope).........

\section{ARTIODACTYLA.}

ELOTHERIIDE (=ENTELODONTIDE).

Elotherium (=Entelodon) mortoni

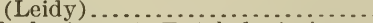

Elotherium (=Entelodon) ingens Leidy ........................... Elotherium (=Entelodon) crassus

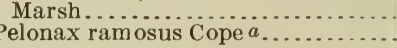

DICOTYLIDA: (=TAGASSUID $E$ ).

Perchœerus probus Leidy ........... $X$ Perchøerus nanus (Marsh).......... $\times$

\section{ANTHRACOTHERIIDA.}

Anthracotherium curtum (Marsh).. Hyopotamus (=Ancodon) rostra-

tus (Scott) $\ldots \ldots \ldots \ldots \ldots \ldots \ldots$

LEPTOCHARIDE, $h$

Leptochøerus spectabilis Leidy ...... Leptochœrus lemurinus (Cope).....

\section{2.3 .}

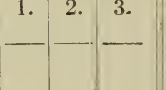

\section{$\Lambda$ griochnerus latifrons Ieidy}

reodon (=Merycoidodon) culbert-

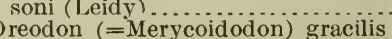
Leidy Oreodon (=Merycoidodon) coloradensis Cope.................... Oreodon (= Merycoidodon) periculorum Cope .....................

Oreodon (= Merycoidodon) macrorhinus Douglass.................. Oreodon (= Merycoidodon) sp. cl.

Leptauchenia sp................... $\times$

\section{HYPERTRAGULIDE.}

Hypertragulus calca ratus Cope.... Hypertragulus $s \rho$. div............... Leptomery $x$ evansi Leidy............ I.eptomeryx sp. div................ Hypisodus minimus Cope..........

\section{CAMEI.IDE.}

Poëbrotherium wilsoni Leidy.

Poëbrotherium labiatum Cove.

Poëbrotherium eximium Hay........

Paratylopus primævus Matthew...

\section{UPPER OLIGOCENE.}

\section{First Phase-Brule, UPPER PAR'T} (White River group).

\section{Protoceras and lower Leptauchenia zones.}

1. Upper Brule, South Dakota and adjoining parts of Nebraska and W yoming.

2. Lower Martin Canyon, Colorado.

3. White Buttes, North Dakota.d

4. Blacktail Deer Creek, Montana (?).e

\section{SECOND PHASE-John Day.}

\section{Diceratherium and Promerycochoerus zones.}

1. John Day, Oregon.c

2. ? Drummond, Montana.

\section{CARNIVORA (FISSIPEDIA).}

\section{CANIDE.}

Paradaphænus cuspigerus (Cope)

Paradaphænus transversus W. and $\mathbf{M}$.

(Cope) .................................

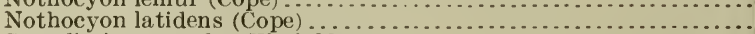

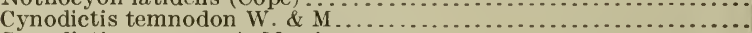

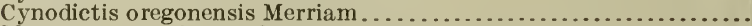

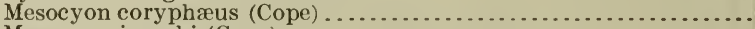

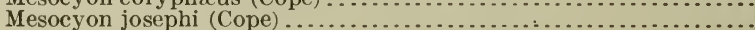

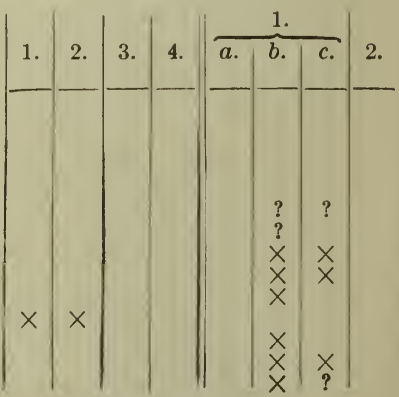

$a$ ? Upper Oligocene.

$b$ This group may perhaps belong in Dichobunidæ.

c Chiefly auct. J. C. Merriam and W. J. Sinclair. The level of many species (marked "? ") is doubtful as it is determined only by character of matrix. Where the level is unknown, it is given as between $b$ and $c$, the lower beds of the formation being practically barren.

$d$ Additional species from this region have been described by $D$ ouglass since the date of preparation of these lists. See Ann. Carnegie Mus., vol. 4, No. 2, 1907. The Oreodon horizon is also included in these exposures.

e More probably Lower Miocene. 
UPPER OLIGOCENE-Continued.

CARNIVORA (FISSIPEDI A) Continued.

CANIDA-Cont inued.

Mesocyon drummondanus Douglass

Mesocyon brachyops Merriam.

Temnocyon altigenis cope...

Temnocyon

Philotrox condoni Merriam

Enhydrocyon stenocephalus Cope

Enhydrocyon basilatus Cope.

Enhydrocyon sectorius (Cope)

\section{MUSTELIDA.}

Oligobunis crassivultus $a$ (Cope)

Parictis primævus Scott

\section{FELIDE.}

Dinictis bombifrons Adams.

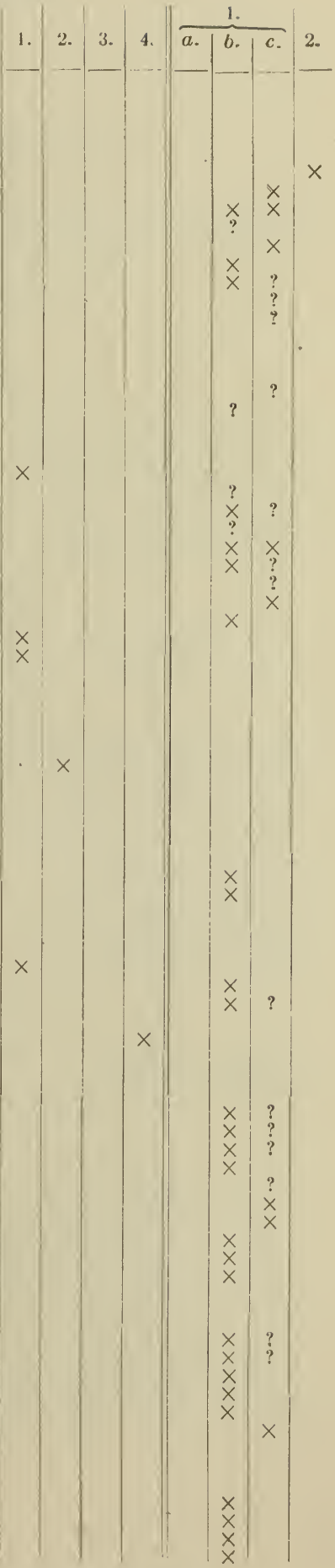

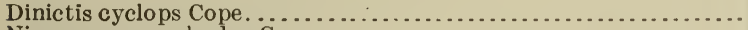

Nimravus gomphodus Cope.

Nimra vus confertus Cope.

Nim ravus debilis (Cope) .....

Pogonodon platycopis (Cope)

Pogonodon brachyops Cope.

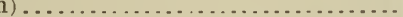

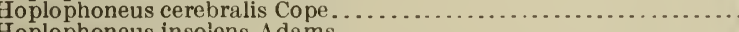

Hoplophoneus insolens Adams.

Eusmilus dakotensis Hatcher

\section{INSECTIVORA.}

TALPIDE.

Proscalops miocænus Matthew

\section{RODENTIA.}

SCIURIDE.

Prosciurus wortmani (Cope)

Prosciurus ballovianus (Cope)

\section{Castoride.}

Steneofiber nebrascensis (Leidy)

Steneofiber peninsulatus Cope.

Steneofiber gradatus Cope.

Steneofiber complexus Douglass $b$

Steneofiber hesperus Douglass.

\section{GeOMYide.}

Entoptychus cavifrons Cope.

Entoptychus planifrons Cope.

Entoptychus minor Cope

Entoptychus crassiramis Cope

Entoptychus lambdoideus Cope

Entoptychus sperryi Sinclair...

Pleurolicus sulcifrons Cope.

Pleurolicus diplophysus Cope.

\section{APLODONTIDE.}

Allomys nitens Marsh

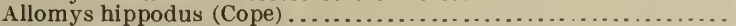

Allomys multiplicatus (Cope)

Allomys liolophus (Cope)

tllomys cavatus (Cope)

Mylagaulodon angulatus Sinclair

MURIDE.

Paciculus $c$ lockingtonianus (Cope)

Paclculus insolitus Cope

Peromyscus nematodon (Cope

Peromyscus parvus Sinclair.

$a$ See Matthew, Bull. Am. Mus. Nat. Hist., 1907, p. 193, for position of this genus.

$b$ Madison Valley, Montana, ?Protoceras zone.

$c$ Related to Dipodidx auct. Scott. 
UPPER OLIGOCENE-Continued.

RODEN'TIA-Contịnued

LEPORID.S.

Palæolagus agapetillus Cope. .

Palæolagus intermedius Matthew

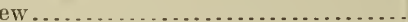

PERISSODACTYLA.

HYRACODONTID.E.

Hyracodon sp. div

RHINOCEROTID舟.

Cænopus tridactylus Osborn .

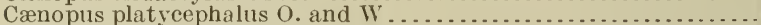

? Cænopus pacificus Leidy $a$.

? Cænopus truquianus Cope.

(l)

等

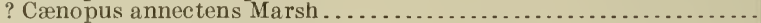

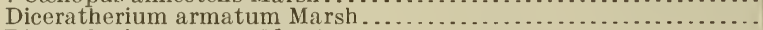

Diceratherium nanum Marsh

\section{TAPIRID.E.}

Protapirus robustus Sinclair.

Protapirus obliquidens $\mathrm{W}$. and $\mathrm{E}$. . . . . . . Protapirus validus Hatcher.

\section{EQUID}

Mesohippus intermedius $\mathrm{O}$. and $\mathrm{W}$

Mesohippus meteulophus Osborn.

(n.............................

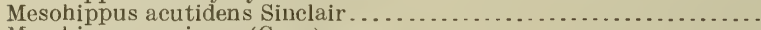

Mesohippus equiceps (Cope)...

Mesohippus brachylophus (Cope) - - - . - . -

Mesohippus longicristis (Cope) ..

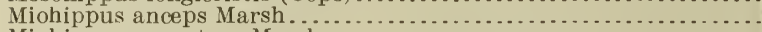

Miohippus annectens Marsh

Miohippus condoni (Leidy)

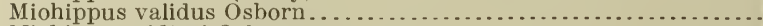

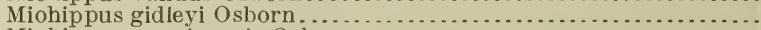

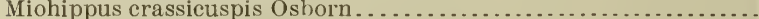

Anchitherium præstans Cope..

\section{ChALICOTHERIID瓜.}

Moropus ("'Lophiodon') oregonensis Leidy ................... Moropus senex Marsh...

Moropus distans Marsh.

\section{ARTIODACTYYA.}

ELOTHERIID压 (= ENTELODONTID尼).

Dæodon $b$ shoshonensis Cope

Boöchœerus humerosus Cope

? Elotherium (=Entelodon) imperator Leidy

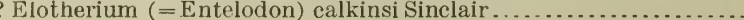

Elotherium (=Entelodon) ef. ingens Leidy. .

Elotherium (=Entelodon) ? crassus Marsh.

(=Entelodon) Pathrodon Marsh...

Elotherium (= Entelodon) sp.

$a$ This and the three following species may be referable to Diceratherium.

$b$ Dæodon Cope, 1878, Boöchœrus Cope, 1879, and Dinohyus Peterson, 1906, quite probably refer to one and the same genus, distinguished from Elotherium by slight development of chin bosses, moderate expansion of dependent processes of jugals, and certain minor changes in the premolars. $E$. calkinsi Sinclair belongs to this group, and perhaps other John Day species. 
UPPER OLIGOCENE-Continued.

\section{ARTIODACTYLA-Continued.}

DICOTYLID (= TAGASSUIDA).

Perchoerus robustus (Marsh)

Perchœrus pristinus (Leidy)

l'erchøerus subæquans (Cope)

Perchoerus rostratus (Cope;

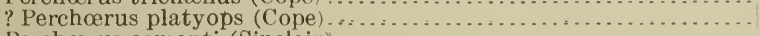

Perchœrus osmonti (Sinclairy

Chænohyus decedens Cope. .

LEPTOCHERIDE.

Leptochœrus $\mathrm{sp}$

\section{ANTHRACOTHERIIDE.}

Anthracotherium karense $\mathrm{O}$. and $\mathrm{W}$.

Hyopotamus (=Ancodon) liachyrhynchus () . and $w$

Arretotherium acridens Douglass.

OREODONTIDE (= IGRIOCHERID,E).

Agriochøerus major Leidy.

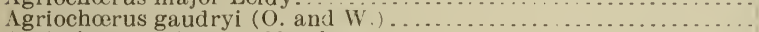

Agriochœrus migrans (Marsh) .

Agriochœrus ferox (Cope)

-

(Cope)

Ariohoerus ryderanus (Cope)

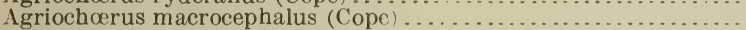

Agriochœrus trifrons (Cope)

Eporeodon (") Eucrotaphus) occidenta

Eporeodon (?= Eucrotaphus) leptacanthus (Cope

pape (Cope)

Eporeodon (? - Fucrotaphus) longifrons (Cope)

Eporeodon (? = Eucrotaphus) major (Leidy) .

Eporeodon (?=Eucrotaphus) cedrensis Matthew

Eporedon (?= Eucrotaphus) socialis Marsh....

Eucrotaphus jacksoni Leidy

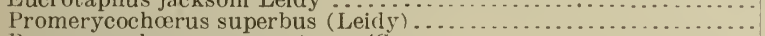

Promerycochœerus macrostegus (Cope) . . . . . . . . . . . . . . . . . . . . . .

Promerycochøerus chelydra (Cope)

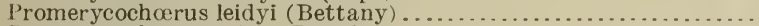

Promerycochœerus minor Douglass

\section{HYPERTRAGULID \&.}

Hypertragulus hesperius Hay.

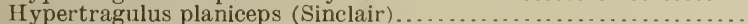

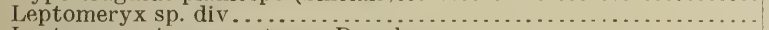

Leptomeryx transmontanus Douglass . . . . . . . . . . . . . . . . . . . .

Protoceras celer Marsh.

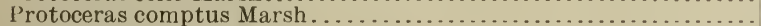

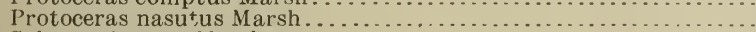

Calops cristatus Marsh.

Calops consors Marsh

\section{Camelide.}

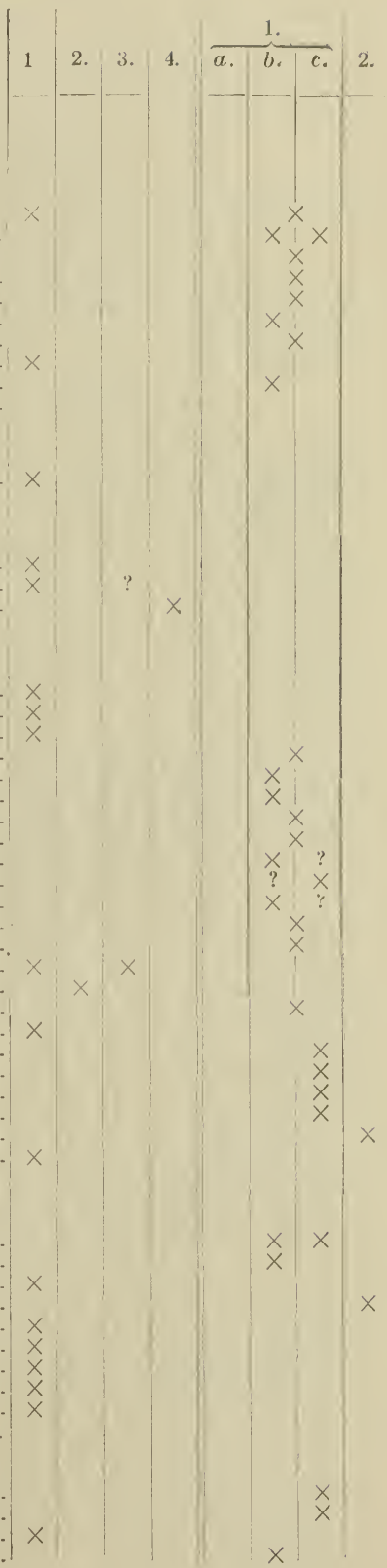

Paratylopus sternbergi (Cope

Paratylopus cameloides (Wortman) . . . . . . . . . . .

Pseudolabis dakotensis Matthew.

Camelidæ indet. 


\section{Range of Oligocene genera.}

\section{MARSUPIALIA}

Didelphyid $x$

Peratherium.

\section{CARNIVORA (CREODONTA).}

Hyænodontidæ (Hyænodontinæ)

Pseudopterodon

Hemipsalodon.

Hyænodon

\section{CARNIVORA (FISSIPEDIA).}

Canidæ
? Cynodon
Daphœenus
Cynodictis.
Paradaphænus .
Nothocyon
Mesocyon.
Temnocyon
Philotrox.
Enhydrocyon

Mustelidæ

Bunælurus .

Oligobunis

Fe'idæ.
Dinictis...
Pogonodon
Nimravus.
IIoplophoneus
Eusmilus.

\section{INSECTIVORA}

Leptictidæ .

Ictops

Mesodectes

Erinaceidæ

Proterix.

Soricidæ

Protosorex

Talpidæ.

Proscalops.

Chrysochloridæ

Apternodus

Xenotherium

Fam. indet.:

Micropternodus

\section{RODENTIA}

Sciuridæ

Prosciu

Cylindrodon

Eutypomys

Steneofiber

Ischy romyidæ.

İschyromys.

Gymnoptychus

Geomyidæ.

Entoptychus

Pleurolicus .

Aplodontiidæ.

Meniscomys.

Mylagaulodon

Muridæ.

Eumys...

Paciculus...

Leporidæ

Palæolagus

Lepus.

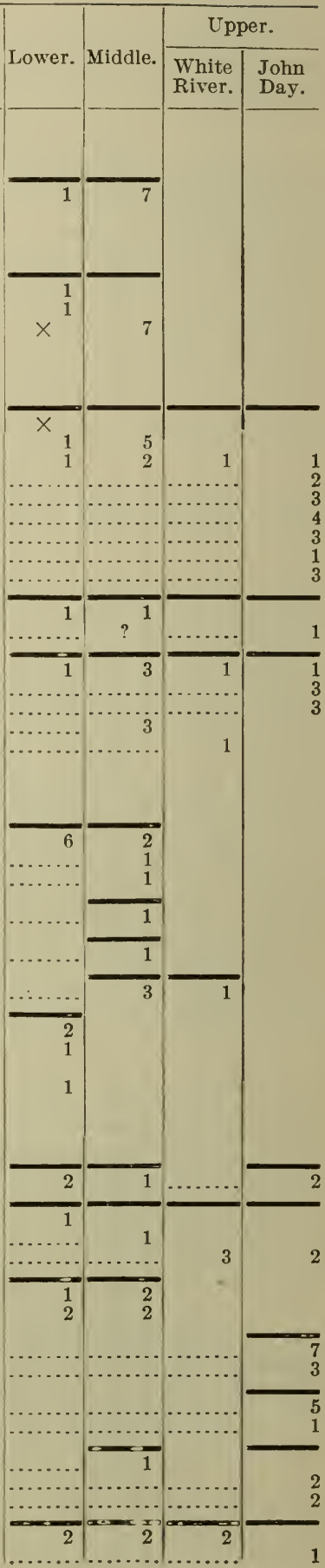


Range of Oligocene genera-Continued.

PERISSODACTYLA.

Hyracodontidæ

Hy racodon.

Amynodontidæ

Metamynodon.

Rhinocerotidæ

Trigonias.

Leptaceratherium

Cænopus.

Diceratherium

Lophiodontidæ

Tapiridæ...

Protapirus.

Equidæ.

Mesohippus

Miohippus.

Anchitherium

Chalicotheriidæ

Moropus....

Titanotheriidæ.....

Megacerops $t .$.

Brontotherium

Symborodon.

\section{ARTIODACTYLA.}

Elotheriidæ

Elotherium $b$

Dicotylidæ.

Perchoris.

Chænohyus

Leptochœridæ

Stibarus.

Leptochor rus.

Anth racotheriidm

Anth racotherium

Hyopotamus..

? Arretotherium

Oreodontidæ.

Bathygenys.

Oreodon.

Iimnenetes.

Eporeodon.

Promerycochœrus.

Leptauchenia.

Agriochœrus .

Hypertragulidæ

Trigenicus...

Leptomeryx.

Heteromeryx

Protoceras.

Calops .........

Hypisodus.

Camelidæ

? Leptotragulus

Paratylopus....

Poëbrotherium

Pseudolabis.

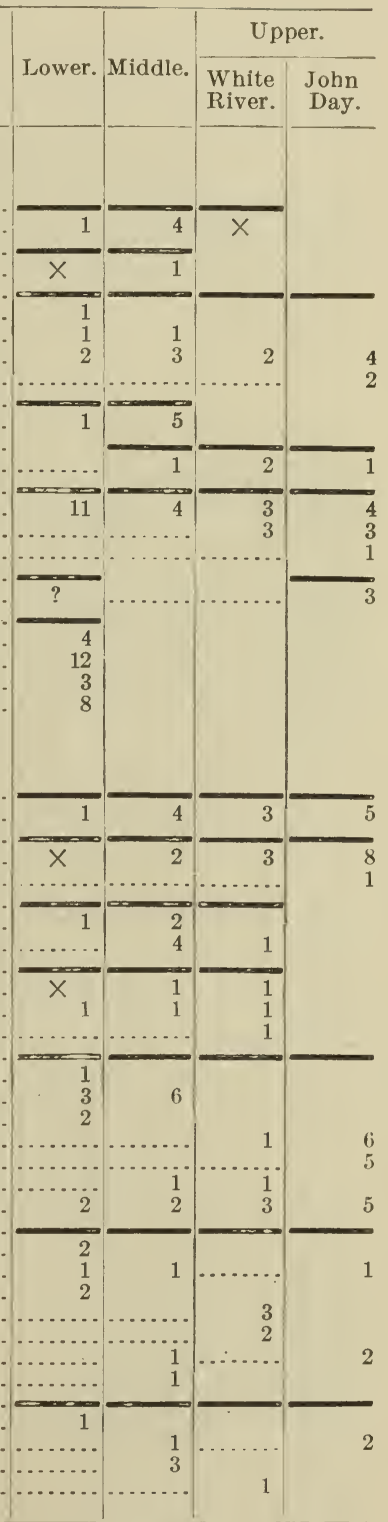

a Including Allops.

$b$ Including Pelonax, Dæodon, and Boöchœrus. 


\section{LOWER MIOCENE.}

\section{ARIKaree Formation (IN PART).}

Promerycochœrus zone.

First phase-Harrison.

1. Fort Logan, Montana.

2. Harrison, Nebraska.

3. Monroe Creek, Nebraska.

4. Lower Rosebud, South Dakota.

5. Canyon Ferry, Montana.

\section{SECOND PHASE.}

1. Laramie Peak, Wyoming.

2. Upper Harrison, Nebraska.

3. Upper Rosebud, South Dakota.

4. Uppermost Martin Canyon, Coloradc

\section{CARNIVORA.}

CANIDE.

Nothocyon gregorii Matthew Nothocyon vulpinus Matthew..........................
Nothocyon annectens Peterson ......................

Cynodesmus thoöides Scott. Mesocyon robustus Matthew

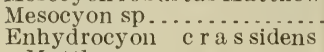

Matthew..................

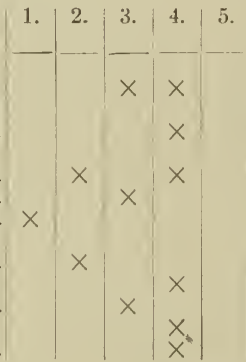

Cynodesmus brachypus (Cope) Cynodesmus thomsoni Mat-

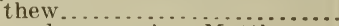
Cynodesmus minor Matthew...

PROCYONIDE.

Phlaocyon lencosteus Matthew.|

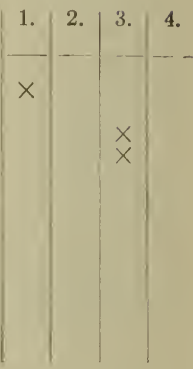
USTELIDE.

? Brachypsalis simplicidens Peterson

Oligobunis lepidus Matthew ....
Megalictis ferox Matthew

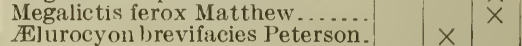

FELIDE.

Nimravus sectator Mattheiv

\section{INSECTIVORA.}

CHRYSOCHLORIDA.

li Aretoryctes terrenus Matthew.. | | $|\times|$

\section{RODENTIA.}

Castoride.

Euhapsis brachyceps PeterEuhapsis gaulodon Matthew Steneofiber ? pansus Cope... Steneofiber fossor Peterson. Steneofiber barbouri Petersteneofiber simplicidens Matthew ................... thew .................. Steneofiber brachyceps Mat-

thew
Steneofiber montanus scott

Meniscomys sp.

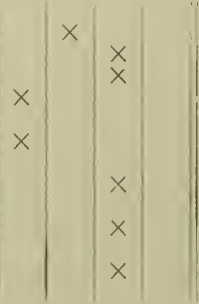

APLODONTIIDE.

$\times$

GEOMYIDE.

Entoptychus formosus Matthew ................... thew ................. ? $\mid \begin{aligned} & x \\ & x\end{aligned}$

Entoptychus formosus Matthew Entoptychus curtus Matthew ..

HETEROMYIDE.

Heteromyidie indet........... $|\quad| \times \mid$ 


\section{LOWER MIOCENE-Continued.}

ROIDENTIA-Continued.

I,EPORIDE.

Lepus primigenius Matthew Lepus macrocephalus Matthew..

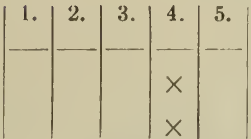

Lepus macroeephalus Matthew

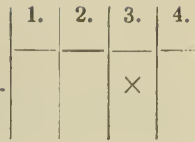

PERISSODACTYLA.

\section{RHINOCEROTIDE.}

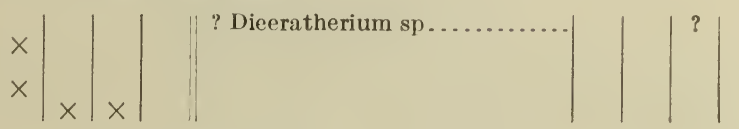

\section{Chalicotherinde.}

Moropus ? elatus Marsh..... | |

EQUIDE.

Parahippus aff. crenidens Scott.....................

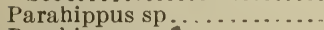
Parahippus sp:............

Anchitherium sp...........

"Miohippus annectens

"Marsh" ...................

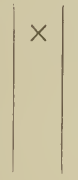

Parahippus nebrascensis Peter-

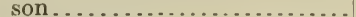

Parahippus sp ................. Parahippus sp

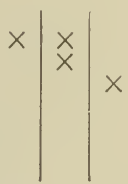

ARTIODACTYLA.

ELOTHERIIDE (=ENTELODONTIDE).

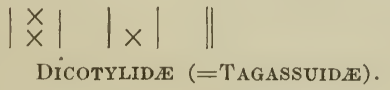

Desmathyus siouxensis ( $\mathrm{Pe}-$ trrson) ..................

Mesoreodon chelony $\mathrm{x}$ Scott Mesoreodon inte $\mathrm{r} \mathrm{m}$ e d $\mathrm{i} \mathrm{u}$ Scott.

Mesoreodon megalodon Peterson.................... Mesoreodon? latidens Douglass.

Eporeodon sp. div...........

Promerycochœrus earriker Peterson ................. Promerycoehœrus vantasselensis Peterson ......... Promerycochœrus sp. div... Promerycochœerus hatcheri Douglass.

Promeryeoehoerus grandis Douglass ................. Promeryecehœrus hollandi Douglass................. Merycoides eursor Douglass. Phenaeocolus typus Peterson .......................

"Merychyus elegans Leidy",

"Meryehyus" harrisonensis Peterson ................. Leptauchenia sp................. Leptauchenia major Leidy... Leptauchenia nitida Leidy..
Desmathyus pinensis Matthew . Desmathyus sp............... $|\times|^{X}$

OREODONTIDE (=AGRIOCHCRIDE).

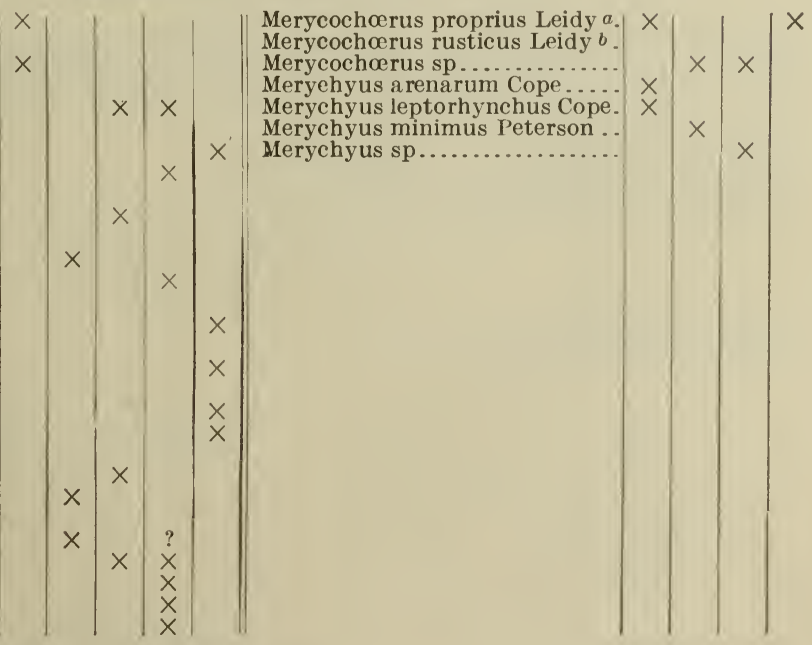

a "Headwaters of Niobrara River, near Fort Laramie."

$\checkmark$ Sweetwater River, Wyoming.

c Specific referenee probably erroneous, generic reference of this and the following species doubtful. The typical Merychyus is from the upper Miocene; the skull structure in the middle Miocene speeies is considerably more specialized than in any from the lower Miocene and although unknown in the upper Miocene speeles is presumably still more speeialized. The species from this early phase of the lower Miocene have in general more brachydont molars, and it may prove neeessary to separate them gener. ieally.

56092-Bull. $361-09-8$ 
LOWER MIOCENE-Continued.

ARTIODACTYLA-Continued.

CAMELIDE.

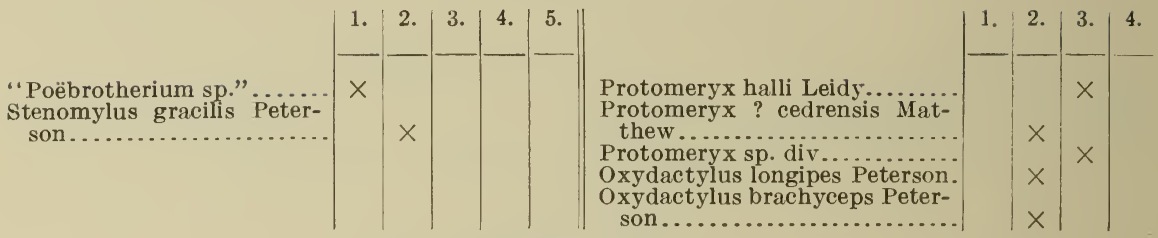

HYPERTRAGULIDE.

Syndyoceras cooki Barbour. Hypertragulus ordi n a $\mathrm{tus}$ Matthew............... Hypertragulus "calcaratus cope".

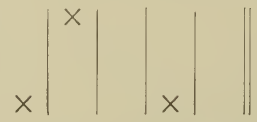

ANTILOCAPRIDE (MERYCODONTINE).

$\begin{aligned} & \text { Blastomeryx advena Matthew... } \\ & \text { Blastomery } \mathrm{x} \text { sp................ }\end{aligned}|\times| \times \mid$

\section{MIDDLE MIOCENE.}

Deep River sequence.

Ticholeptus zone.

1. Deep River (Smith River), Montana.

2. Pawnee Creek, northeastern Colorado.

3. Flint Creek, Montana; ? North Boulder Creek, Montana, etc.

4. Mascall, Oregon.

\section{CARNIVORA.}

\section{CANIDE.}

Tephrocyon rures ris Merriam. Cynarctus saxatilis Matthew... Amphicyon sinapius Matthew.. "Canis" anceps Scott.......... 'Canis', cf. temerarius Leidy... "Canis" sp................... Tomarctus brevirostris Cope... ?Cyon aut Icticyon sp.......... ??Aelurodon brachygnathus Douglass.

\section{MUSTELIDA.}

Mustela parviloba Cope. Mustela ogygia Matthew...... Potamotherium lycopotamicum Cope.

\section{FELIDE.}

Pseudælurus ?intrepidus Leidy.

\section{INSECTIVORA.}

TALPIDE.

Talpa platybrachys Douglass..

\section{RODENTIA.}

SCIURIDE.

Sciurus $\mathrm{sp}$

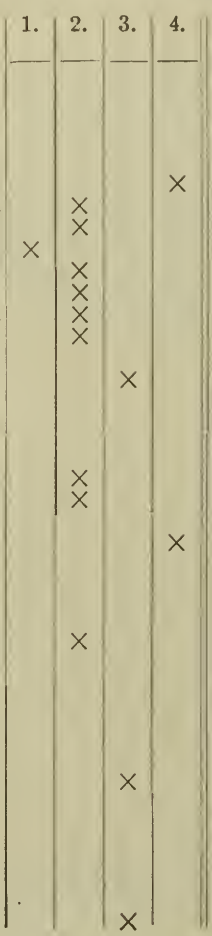

RODFNTIA-Continued. MYLAGaUlide.

Mylagaulus lævis Matthew.... Mylagaulus paniensis Matthew Mesogaulus ballensis Riggs..... Ceratogaulus rhinocerus Matthew.

GEOMYIDE.

Geomys sp.a

\section{EDENTATA.}

? MEGALONYCHIDE.

Gen. innom. Sinclair.

\section{PROBOSCIDEA.}

ElephaNTIDE.

Trilophodon (=Gomphotherium) proavus (Cope)......... Trilophodon (=Gomphotheriuin) breviceps (Cope) ........ $\times$

\section{PERISSODACTYLA.}

\section{RHINOCEROTIDE.}

Cænopus persistens Osborn.... Aphelops megalodus Cope...... A phelops profectus (Matthew). A phelops planiceps Oshorn. ? Aphelops oregonensis (Marsh). ? Aphelops sp................ Teleoceras medicornutus Osborn.......................

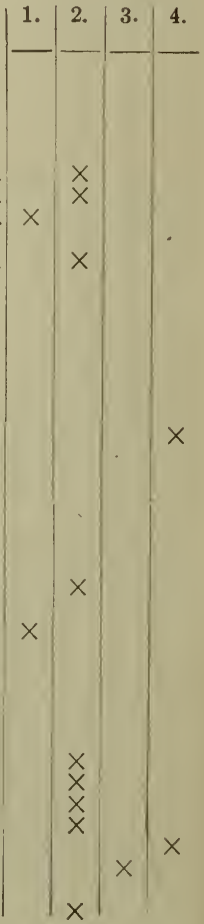

$a$ Blue Creek, Nebraska, associated with Cyclopidus. 
MIDDLE MIOCENE-Continued.

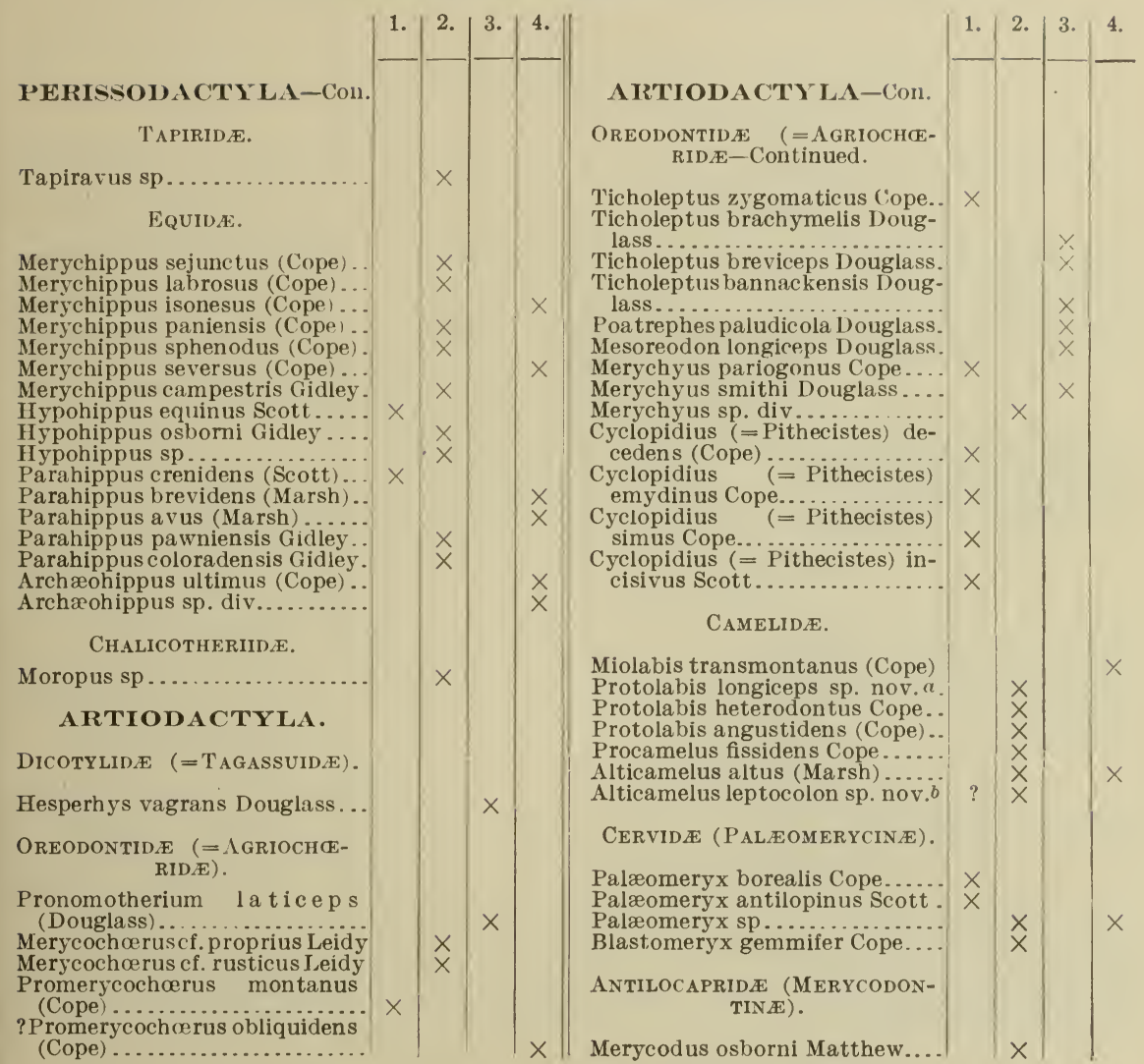

\section{UPPER MIOCENE AND ? LOWER PLIOCENE.}

\section{First phase-Arikaree formation} (IN PART).

\section{Procamelus zone.}

1. Fort Niobrara ("Nebraska formation"), $\mathrm{Ne}-$ braska.

2. Little White River, South Dakota

3. Santa Fe, New Mexico.

4. Clarendon, Texas.

5. Madison Valley, Montana.

\section{Second Phase-Ogalalla formation.}

Peraceras zone (doubtfully separable).

1. Republican River, Kansas and Nebraska.

2. Archer, Florida (Álachua clays).

3. Rattlesnake, Oregon.

\section{CARNIVORA.}

\section{CANIDE.}

Ælurodon sævus (Leidy).

Elurodon haydeni (Leidy)

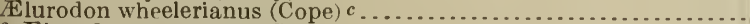

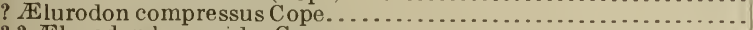

? ? Elurodon hyænoides Cope........................................

Amphicyon americanus Wortman......................................

? Dinocyon ursinus (Cope) ..................................

Dinocyon mæandrinus Hatcher....................................

Dinocyon gidleyi Matthew .......................................

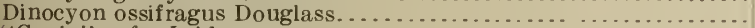

"Canis", vafer Leidy ..................

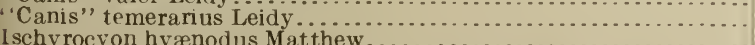

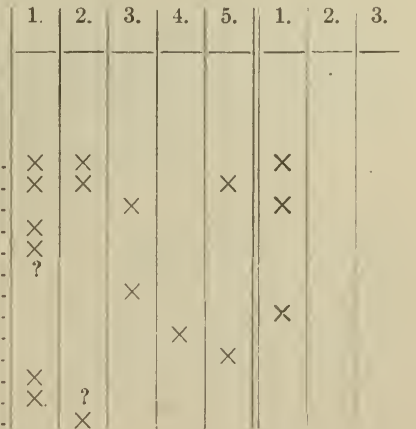

$a$ "P. montanus Douglass," Matthew, Mem. Am. Mus. Nat. Hist., vol.1, pt. 7, 1901, p. 435, figs. 31-33. Not $P$. montanus of Douglass.

b "Procamelus robustus Leidy," Matthew, op. cit., p. 427, fig. 30. Not P. robustus of Leidy.

$c$ Including $\mathscr{E}$. taxoides Hatcher. 
UPPER MIOCENE AND ? LOWER PLIOCENE-Continued.

CARNIVORA-Continuer.

? PROCYONIDE.

\section{RODEN'TIA.}

SCIURIDE.

Sciurus arctomyoides Douglass.

Palæarctomys montanus Douglass.

Palearctomys macrorhinus Douglass.

Palearctomys macrorhinus Douglass.........................

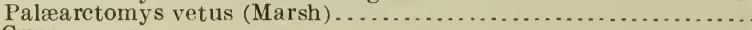

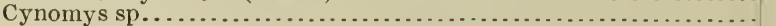

\section{CASTORIDA.}

Eucastor (=Dipoides) tortus Leidy

Sigmogomphius lecontei Merriam.

\section{MYlagaulide,}

Mylagaulus sesquipedalis Cope

Mylagaulus monodon Cope.

Mylagaulus pristinus Douglass.

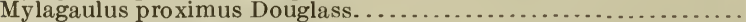

Mylagaulus paniensis Matthew

Epigaulus hatcheri Gidley....

\section{GEOMYIDE.}

Geomys bisulcatus Marsh..

\section{MURIDE.}

Hesperomys (= Peromyscus) loxodon (Cope)

\section{LEPORIDE.}

Panolax sanctæfidei Cope Lepus sp.

\section{PROBOSCIDEA.}

\section{ELEPTINTIDA.}

Trilophodon (=Gomphotherium) productus Cope

Trilophodon (=Gomphotherium) euhypodon Cope.

Trilophodon ( $=$ Gomphotherium) campester Cope.

Trilophodon ( $=$ Gomphotherium) præcursor Cope.
Trilophodon (= Gomphotherium) floridanus Leidy

\section{PERISSODACTYLA.}

RHINOCEROTIDE.

Teleoceras fossiger Cope.

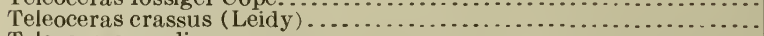

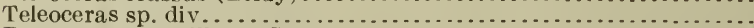

Peraceras superciliosus Cope...............................

? A phelops malacorhinus Cope..........................

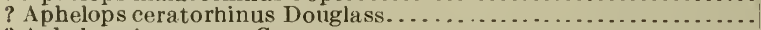

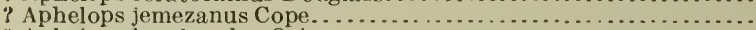

Aphelopstrachyodus Or

\section{TAPIRIDE.}

\begin{tabular}{l|l|l|l|l|l|l|l|} 
1. & 2. & 3. & 4. & 5. & 1. & 2. & 3. \\
\hline
\end{tabular}

Bijou Hills.

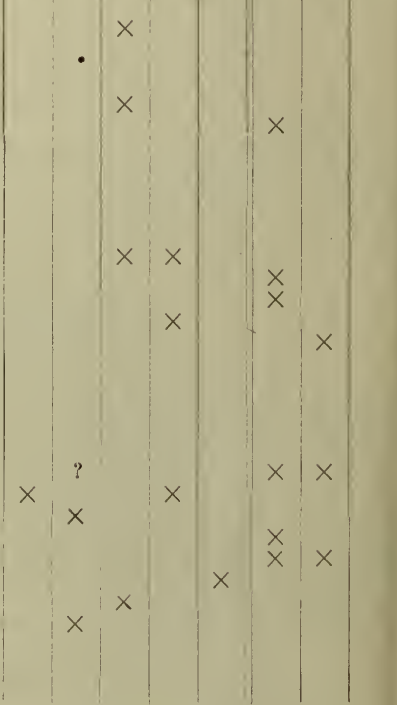

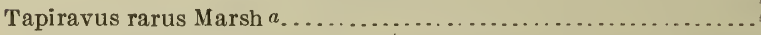


UPPER MIOCENE AND ? LOWER PLIOCENE-Continued.

PERISSODAC'YY I.A-Continued.

EQUIDE.

Hypohippus affinis Leidy .

Hypohippus sp........................

Merychippus insignis Leidy.

Protohippus mirabilis Leidy.

Protohippus perditus Leidy

Protohippus placidus Leidy.

Protohippus supremus Leidy -

Protohippus pernix (Marsh)

? Protohippus parvulus (Marsh)

Protohippus gracilis (Marsh).

Protohippus spectans (Cope)

Protohippus pachyops Cope.

Protohippus castilli Cope...

Protohippus profectus Cope.

Protohippus simus Gidley...

Protohippus fossulatus Cope.

Protohippus interpolatus Cope

Neohipparion whitneyi Gidley

Neohipparion occidentale (Leidy)

Neohipparion speciosum (Leidy)

Neohipparion affine (Leidv).

Neohipparion gratum (Leidy)

Neohipparion calamarium (Cope)

Neohipparion relictum (Cope).

Neohipparion montezumæ (Leidy)

Neohipparion peninsulatum (Cope)

Neohipparion lenticularis (Cope)

Neohipparion dolichops Gidler.

Neohipparion niobrarense Gidley.

Neohipparion sinclairii Wortman.

Neohipparion retrusum Cope.

Neohipparion princeps Leidy

Neohipparion eurystylus (Cope).

Neohipparion ingenuum (Leidy).

Neohipparion rectidens (Cope)

Neohipparion plicatile (Leidy)

\section{ARTIODACTYLA.}

DICOTYLIDE (=TAGASSUIDE).

Prosthennops crassigenis Gidley

Prosthennops serus (Cope).

"Platygonus" striatus Marsh.

\section{OREODONTIDE (=AGRIOCMERIDE)}

Pronomotherium altiramis Douglass.

? Merycochøerus cenopus Scott \& Osborn.

? Merycochøerus sp.

Merychyus elegans Leidy.

? Merychyus medius Leidy.

? Merychyus major Leidy.

? Merychyus sp.

\section{CAMELIDE.}

Procamelus occidentalis Leidy

Procamelus robustus Leidy.

Procamelus gracilis Leidy

? Procamelus prehensilis (Cope)

Procamelus leptognathus Cope.

Procamelus major Leidy .

Procamelus minor Leidy...

Procamelus minimus Leid $y$.

Procamelus madisonius Douglas.

Procamelus lacustris Douglass.

Procamelus sp. div ..............

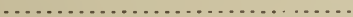

Protolabis serus (Douglass)

Pliauchenia humphreysiana Cope

Pliauchenia sp..................

Pliauchenia minima Wortman.

Pliauchenia sp. max.

a"Pliauchenia humphreysiana Cope," Wortman, 1899, not of Cope. Jaw larger, more robust, premolars more reduced, p. 2 absent, wbile in $P$. humphresiana it is vestigial.

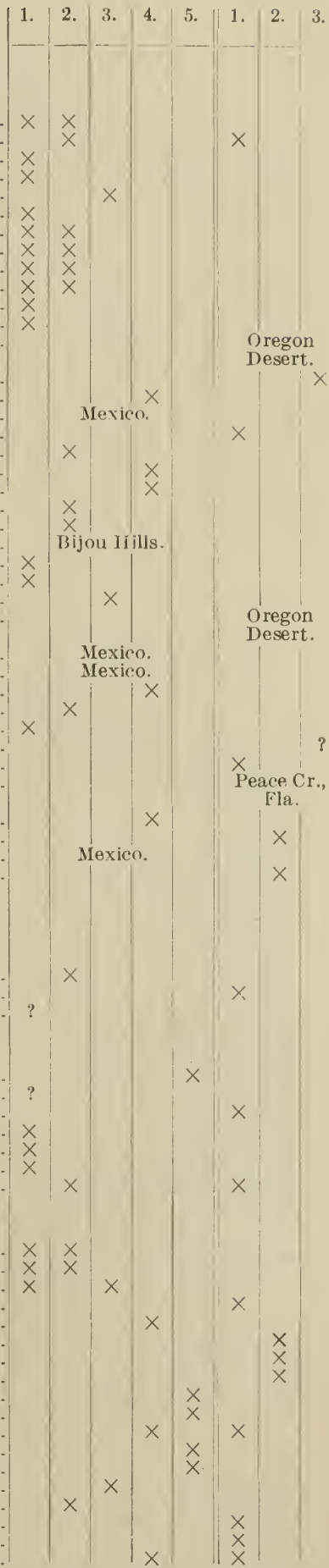


UPPER MIOCENE AND ? LOWER PLIOCENE-Continued.

\section{ARTIODACTYLA-Continued.}

\section{Cervide.}

Palæomeryx americanus Douglass.

Palæomeryx teres (Cope).

Palæomeryx trilateralis (Cope)

Palæomeryx sp. div

Blastomeryx wellsi Matthew

\section{ANTILOCAPRIDE (MERYCODONTINE).}

Merycodus necatus Leidy .

Mervcodus furcatus 'Leidy)

Merycodus ramosus (Cope

Merycodus agilis Donglass.

? Merycodus tehuanus (Cope)

\section{Range of Miocene genera.}

[The figures show the number of described species in each genus. Crosses indicate that the presence of the genus is recorded, but no species have been described.]

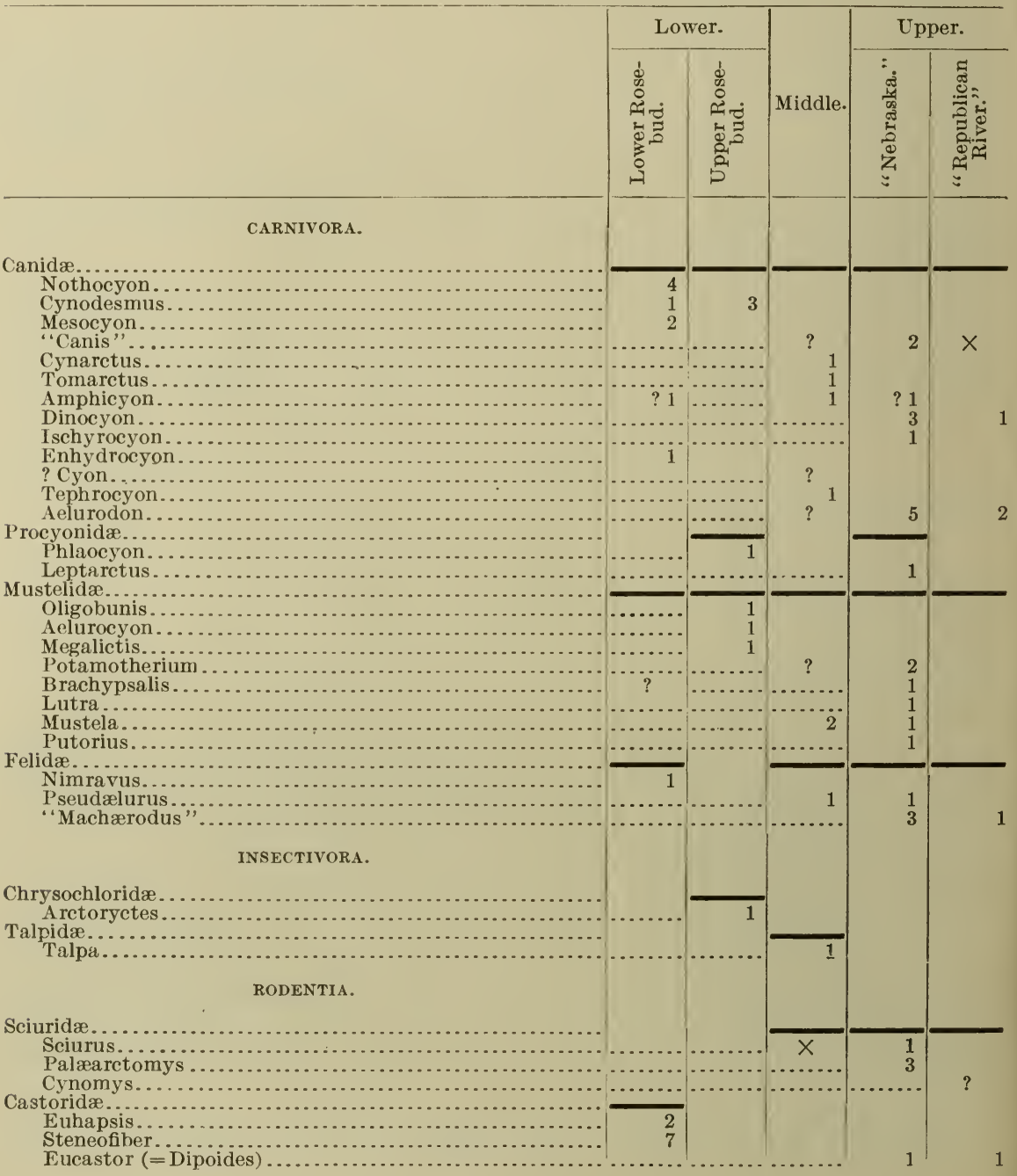


Range of Miocene genera-Continued.

\section{RODENTIA-continued.}

Mylagaulidæ.

Mylagaulus.

Ceratogaulus.

Mesogaulus.

Epigaulus.

Geomyidæ.

Entoptychus

? Geomys

? Thomomys

Muridæ

? Hesperomys (= Peromyscus)

odontidæ... Heteromyidæ.

Heteromyid indet.

Leporidæ..

Lepus...

Panolax.

Megalonychidæ:

Gen. innom .

EDENTATA.

Elephantidæ

PROBOSCIDEA

Trilophodon (=Gomphotherium)

Rhinocerotidæ.

PERISSODACTYLA.

Diceratherium.

Cænopus

Aphelops.

Teleoceras

Peraceras.

Tapiridæ

Tapiravus.

Equidæ.

Anchitherium.

.

Hypohippus.

Parahippus.

Merychippus.

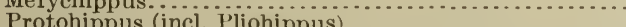

Neohipparion.

Chalicotheriidæ.. Moropus.

\section{ARTIODACTYLA.}

Elotheriidæ (= Entelodontidæ) Elotherium (= Entelodon). Dinohyus.

Dicotylidæ (= Tagassuidæ). Desmathyus..

Prosthennops.

Hesperhys.

Oreodontidæ (= Agriochœridæ) Eporeodon..

Mesoreodon...

Phenacocolus.

Merycoides. .

Merychyus.

Ticholeptus (incl. Poatrephes)

Promerycochœerus

Merycochœerus.

Pronomotherium

Leptauchenia ${ }^{2}$

Cyclopidius.

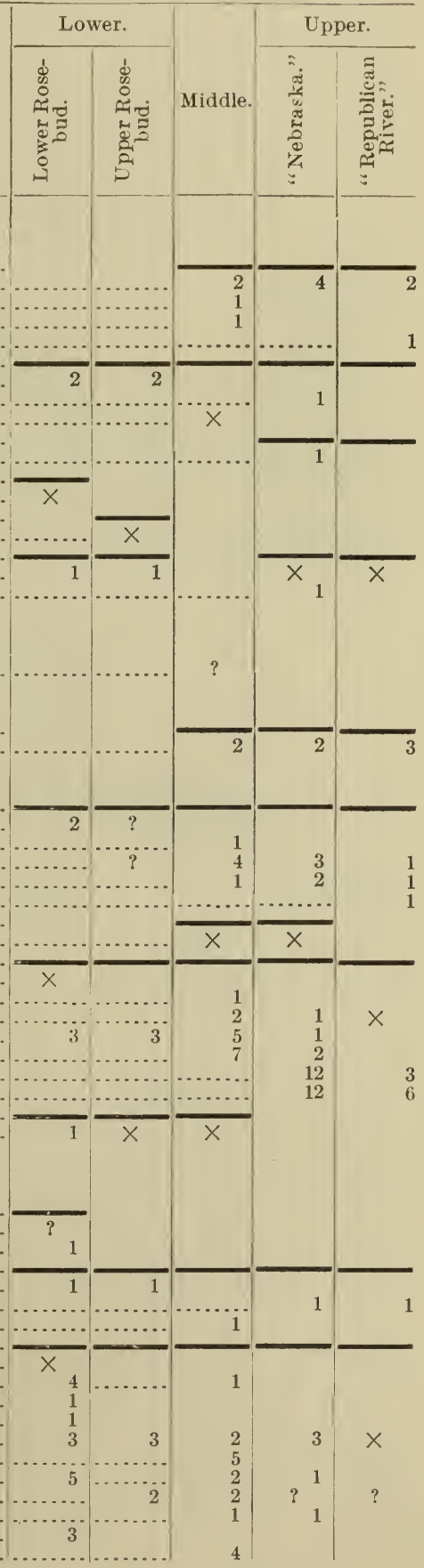


Range of Miocene genera-Continued.

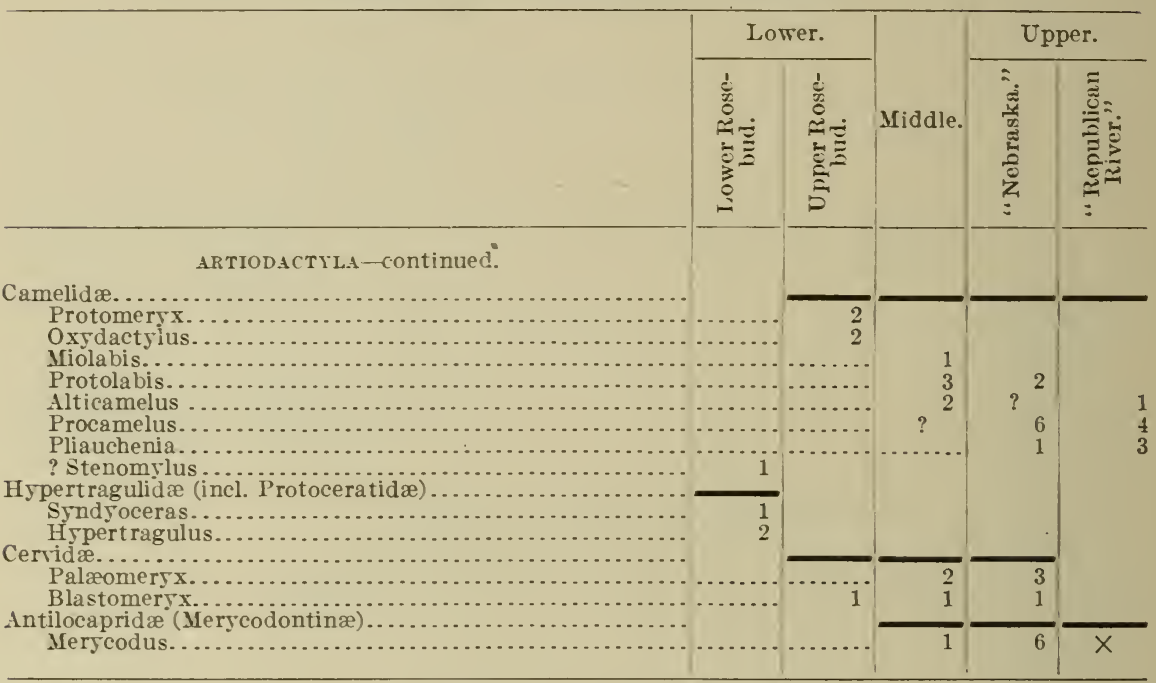

\section{MIDDLE PLIOCENE.}

Blanco formation (Texas).

Glyptotherium zone.

\section{CARNITORA.}

CANTD王.

Borophagus diversidens Cope. ? Amphicyon sp.

\section{MUSTELID王.}

Canimartes cumminsi Cope.

FELID..

Felis hillanus Cope.

\section{EDENTATA.}

GLYPTODONTID.E.

Glyptotherium texanum Osborn.

\section{MEGaLONYCHID.E.}

Megalonyx leptostoma Cope.

MYLODONTID王.

Mylodon sp.

\section{PROBOSCIDEA.}

\section{ELEYHANTID.E.}

Trilophodon(=Gomphotherium)shepardii Leidy. $a$ Dibelodon mirificus Leids.

Dibelodon tropicus Cope.

Dibelodon præcursor Cope.

? Dibelodon humboldtii (Curier)

\section{PERISSODAC'TYLA.}

\section{EQUID王.}

Pliohippus simplicidens (Cope).

Protohippus minutus (Code) (=phlegon (Hay)). Protohippus cumminsii (Cope).

Neohipparion sp.

\section{ARTIODACTILA.}

DICOTYLID.玉 (=TAGASSUID玉).

Platygonus bicalcaratus Cope.

Platygonus texanus Gidley.

\section{CAMELIDE.}

Pliauchenia spatula Cope.

Pliauchenia sp.

a This species should probably be referred to Dibelodon. 


\section{INDEX.}

\section{A.}

Acer.

Aceratheriinæ

Achænodon

insolens.

robustus

uintensis

sp.

Achænodontid $æ$

Achænodontinæ...................... 57,61

Adjidaumo minimus ................... 104 minutus......................... 104,105

trilophus......................... 105

Ælurocyon....................... 74,118

brevifacies...................... 112

Flurodon........................ 80, 81,118

brachygnathus .................... 114

compressus........................ 115

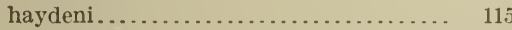

hyænoides..................... 115

sævus........................... 115

taxoides.......................... 115

wheelerianus...................... 115

Agriochœridæ.............. 63, 113, 115, 117, 118

Agriochnerinæ....................... 69

Agriochœrus ....................... 68,111

antiquus.......................... 106

ferox ............................. 109

gaudryi.......................... 109

guyotanus ...................... 109

latifrons.......................... $10 j$

macrocephalus................... 109

major........................... 109

maximus.......................... 104

migrans.......................... 109

minimus........................ 104

ryderanus.......................... 109

trifrons............................ 109

sp................................ 104

Alces............................ 86, 87,89

Allomys............................ 60

caratus........................ 107

hippodus ...................... . 107

liolophus..................... 107

multiplicatus...................... 107

nitens ........................... 107

Allops amplus ...................... 104

crassicornis .......................... 104

serotinus......................... 104

Almy formation, sectiou of, figure showing... $\quad 39$

Alticamelus........................ $78,81,120$

altus ........................... 81,115

leptocolon....................... 115

Ambloctonidæ..................... 93, 100
Ambloctonus - Page

sinosus........................... 93

Amblypoda....................... 33

$35,37,40,41,42,45,49,52,54,56,57,92$, $94,97,99,102$.

American correlation, problem of .......... 29

American-Eurasiatic correlation, problem of. 29-30

American-European faunas, correlation of.... 59

Americoids . . . . . . . . . . . . . . . . . . . . . . 40

Amphicyon............69, $72,74,77,78,83,118$ sinapius......................... 114

superbus........................ 112

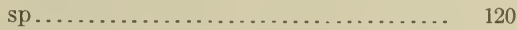

Amphicyoninæ ...................... $\quad 77$

Amynodon............................. 102

advenus........................... 99

antiquus............................ 99

intermedius........................ 99

sp................................ 99

Amynodontidæ........................ 54 ,

$57,60,61,62,63,99,102,104,105,111$

Anacodon ........................ 38,45, 100 ursidens........................... 93

Anaptomorphidæ............. 46, 52, 93, 95, 100

Anaptomorphus...................... 100 abboti............................ 93

æmulus........................... $\quad 95$

homunculus..................... 93

minimus........................... 93

spierianus . . . . . . . . . . . . . .

sp.......................... 9.

Anchippodontidæ................ 94,9 , 101

Anchippodus.......................... 52 vetulus.......................... 97

Anchisodon quadriplicatus............... 105

Anchitherium .................... $75,111,119$ præstans....................... 68, 108 sp................................... 113

Ancodon. See Hyopotainus.

Anguidæ.......................... 47

Anisacodon .......................... 101 elegans............................ 96

Anisonchus ......................... 102

gillianus.......................... 92

sectorius............................. 92

Anthracotheriidæ.................... 55

$60,61,62,63,64,69,104,166,109,111$

Anthracotherium...................... 111 curtum........................... 106

karense........................... 109

sp................................ 104

Antiacodon........................... 96, 101

Antilocapra...................... 85, 86,87 
Page.

Antilocapridæ $77,86,114,115,118,120$

Apatemyidæ. 96,101

Apatemys. bellulus.

101

bellus............................. 96

Aphelops........................ $78,81,119$

brachyodus......................... 116

ceratorhinus..................... 80, 116

jemezanus......................... 116

malacorhinus..................... 81, 116

megalodus........................ 114

oregonensis........................ 114

planiceps......................... 114

profectus............................ 114

Aplodontiidæ................... 10 $107,110,119$

Apternodus ............................ $\quad 110$ mediævus......................... 103

Aquitanien étage, homotaxis and fauna of. . 67-75

Aralia............................... 78

Archælurus........................... 68

Archæohippus.................... 78, 119 ultimus........................... 115 sp................................. 115

Archaic mammals, elimination of.......... 35 orders of.

Archer, Fla., fauna at................. 115-118

Arctocyonidæ........ 33, 34, 35, 40, 42, 45, 91, 93, 100 Arctomys............................ 90

Arctoryctes......................... 75, 118 terrenus.......................... 112

Arctotherium ...................... 87,89

Arikaree formation, correlation of......... 71 fauna of ............. $70-75,112-114,115-118$ homotaxis of . . . . . . . . . . . . . . . . $70-75$

figure showing................ 70,72

Arretotherium....................... 111 acridens.......................... 109

Artiodactyla.... $33,36,38,40,42,52,54,55,56,57,58$, $59,60,61,62,63,64,66,68,69,73,74,75,77,80$, $81,83,85,86,88-89,90,95,98,99-100,103,104$, $106,108-109,111,113-114,115,117-118,119,120$

Arvicola.............................. $\quad 85$ Astien étage, homotaxis and fauna of....... 82-83

\section{B.}

Banding, occurrence of ................. 27-28 Bartonien étage, homotaxis and fauna of.... 50-57 Bassariscus........................... 89

Bathygenys.......................... 111 alpha............................. 104

Bathyopsis................... 44, 45, 47,102 fissidens.

$43-48,92-95$
-2

Bathyopsis zone, fauna of......... 43-48, 92-95 homotaxis of ................... 43,48 figure showing.................. 44

Beds, use of term...................... 7

Beede, J. W., and Haworth, E., paper by.... 17 Bibliography of western Cenozoic horizons... 9-18 Bighorn Basin, Wyo., fauna of.......... 42, 92-95 sections of, figures showing........... 23, 38

Bison.............................. 87,89 occidentalis.................... 88

Blacktail Deer Creek, Mont., fauna of..... 106-109 Blanco formation, fauna of ........... 82-83, 120 homotaxis of ..................... $82-83$ figure showing................. 82
Page.

Blarina.............................. 90

Blastomeryx............ $70,72,74,75,80,81,120$

advena........................... 120

gemmifer ......................... 115

wellsi......................... 118

sp............................... 114

Bolodontidæ........................ 91,100

Boöchœrus......................... 108

Borophagus..................... 80,83,86

diversidens....................... 120

Bovidæ.................... 85, 86, $88,89,90$

Bovinæ............................ 86

Bozeman lake beds, character of........... $\quad 24$

Brachyprotoma...................... 90

Brachypsalis..................... 74,80,118

pachycephalus.................... 116

simplicidens....................... 112

Bridger Basin, Wyo., section of, figure showing........................ 23

Bridger formation, character of ............. 25-26 distribution of, map showing ........... $\quad 37$ fauna of. . . . . . . . . . . . . . . 50-53,95-100 homotaxis of..................... $50-53$

figures showing .............. 23,39,51

Brontotheriidæ.............. 95,98, 100,104,111

Brontotherium ........................ 111

bucco............................. 104

curtum........................... 104

dolichoceras....................... 104

gigas.............................. 104

hypoceras........................ 104

leidyi........................... 104

platyceras........................... 104

ramosum........................ 104

Brown, Barnum, on Port Kennedy cave

Brule clay, distribution of, plates showing... 7,60

fauna of . . . . . . . . . . . . . . 62-68, 105-109

homotaxis of . ................... $62-68$

figures showing................. 62,64

Buffalo basin, deposits of................ 41

Bunælurus.........................6 63,110

infelix............................ 103

lagophagus....................... 105

Bunodonta......................... 52

Bunomeryx......................... 103

elegans............................. 99

montanus.......................... 99

Burdigalien étage, homotaxis and fauna of... 70-75

C.

Cadurcotherium...................... 62

Cænopus............................ 111,119

annectens........................ 108

copei.............................. 105

mitis................................ 104

occidentalis........................ 105

pacificus.......................... 108

persistens......................... 114

platycephalus.................... 104, 108

simplicidens........................ 105

tridactylus........................ 108

truquianus........................ 108

tubifer............................ 108

sp................................. 104 
Page.

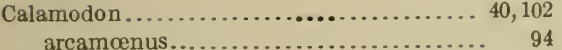

arcamœenus.

novomexicanus.

simplex.

Calops

consors.

94

94

111

cristatus.

109

109

Camelidæ

$66,67,68,73,74,75,76,78,80,81,83,85,86,87,89$

$90,100,103,104,106,109,111,114,115,117,120$

Camelomeryx

Camelops.

100

Camelus.

$85,86,87,89$

Canada, fauna of.

103-105

Canidæ

$63,66,68,73,74,77,78,80,81,83,85,86,89,90$, $99,103,105,106-107,110,112,114,115,118,120$

Carimartes.

cumminsii ................... 120

Canis.......................... 83, $85,89,90,118$

anceps.

114

temerarius........................ 114,115

vafer............................... 115

sp................................. 114

Canyon Ferry, Mont., fauna near......... 112-114

Capromeryx......................... 86,87

Carcinodon............................ 101

filholianus......................... 91

Carnivora............................ 33, $35,40,42,45,46,52,54,56,5 \pi, 58,59,60,61,63$, $68,74,75,77,80,81,83,85,86,89,90,93,96,98-99$, $100-101,103,105,110,112,114,115-116,118,120$

Castor.

$83,85,90$

Castoridæ

$66,68,73,74,81,103,105,107,110,112,116,118$

Castoroides

Catopsalis.

foliatus............................. 91

Cedar Creek, Colo., fauna of ............. 105-106

Ceneutheria........................... 33

Centetes ............................. 61

Centetiidæ......................... 52

Centetodon........................... 101

altidens........................... 96

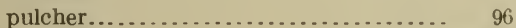

Centetodontidæ..................... 96, 101

Centracodon.......................... 101

delicatus........................... 96

Ceratogaulus......................... 78,119

rhinocerus........................ 114

Cernaysien étage, homotaxis and fauna of. . . 34-35

Cervidæ.... 74, 75, 77, 78, 80, 81, 86, 89, 90, 115, 118,120

Cervus.......................... 86,87,89 canadensis.

90

Chadron, S. Dak., fauna of .............. 103-104

Chadron formation, distribution of, plate showing.

7,60

fauna of

$60-61,103-104$ homotaxis of

$60-61$

figures showing.

62,64

Chænohyus.

111

decedens

109

Chalicotheriidæ.................... 55,60,

$61,62,66,67,69,74,81,104,108,111,113,115,119$

Chalicotherium bilobatum.

104

Cheiroptera.

45,56
Chelydridæ.......................... 58

Chirox................................ 100

plicatus............................ 91

Chriacus............................. 101

baldwini . . . . . . . . . . . . 91

pelvidens.......................... 91

schlosserianus..................... 91

truncatus........................... 91

Chrysochloride.............. $75,103,110,112,118$

Clænodon.......................... 100

corrugatus......................... 91

ferox............................. 91

protogonioides . . . . . . . . . . . . . . . . . . 34,91

Clarendon, Tex., fauna near............ 115-118

Clark, W. B., papers by ................... 9

Clemmys............................ $\quad 58$

hesperia........................ 81

Cockerell, T. D. A., paper by ............. 13

Colodon............................. 111

cingulatus.......................... 105

dakotensis......................... 105

longipes............................. 105

occidentalis...................... 104

procuspidatus....................... 105

Colonoceras.......................... 102

agrestis............................ 97

Colonomys.......................... 101

celer.............................. 97

Colorado, fauna of ............... 92-98, 103-109 formations in, homotaxis of........... 22

figure showing.................. 23,65

Conacodon........................... 102

cophater.......................... 92

entoconus........................ 92

Conard fissure, Ark., fossils of. . . . . . . . . .. 90

Condylarthra......... 33, 35, 40, $41,42,45,92,94,102$

Conoryctes............................ 102

comma............................. 92

Conoryctidæ..................... 34,92,102

Cope, E. D., on archaic mammals......... 34

on Loup Fork beds................... 84

papers by ................... 10,11,13,17

Cope, E. D., and Wortman, J. L., paper by.. 17

Correlation, attempts at............ . \$ $-9,31-32$ methods of ....................... 30-31

problems of........................ 29-30

progress of....................... 8 $8-\theta$

Coryphodon........... 38, $40,41,44,45,47,49,102$

armatus........................... 94

curvicristis......................... 94

elephantopus........................ 94

hamatus.......................... 94

latidens.......................... 94

lobatus.............................. 94

radians............................... 39.94

semicinctus........................ $\quad 39$

singularis.......................... 94

testis................................. 94

ventanus........................ 49,94

wortmani........................... 94

Coryphodon zone, fauna of............. 40,92-95 homotaxis of . . . . . . . . . . . . . . 23, 36-40 figures showing............... 23, 38,39

Coryphodontidæ...... 35, 37-35, 40, 41, 42, 45, 94, 102 Creodonta........ 33, $35,37,40,42,45,52,54,56,57$, $59,60,62,66,91,93,96,98,100-101,103,105,110$ 
Crocodilus.

Cummins, W.F., paper by............... 13

Cyclopidius.......................... 78,114

decedens......................... 115

emydinus.......................... 115

incisivus............................ 115

simus............................ 115

Cylindrodon........................... 110

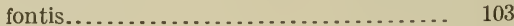

Cynarctus............................. 78

saxatilis............................ 114

Cynodesmus....................... 75, 80,118

brachypus........................ 112

minor............................. 112

thomsoni......................... 112

thoöides........................... 112

Cynodictis...................... 57,61,63,110

gregarius......................... 105

lippincottianus..................... 105

oregonensis........................ 106

paterculus......................... 103

temnodon.......................... 106

sp................................. 103

Cynodon.............................. 110

Cynodontomys.......................... 100

angulatus.......................... 99

latidens........................... 93

sp............................... 93

Cynomys............................ 85, 118

sp.................................. 116

Cyon................................ 118

sp................................... 114

D.

Dæmonelix beds, homotaxis and fauna of ... 73-74 homotaxis of, figure showing .......... 72

Dæodon.............................. 108 Dall, W. H., papers by............... 10, 13, 29

Dall, W. II., and Harris, G. D., paper by.... 13

Daphænus....................... 61,63, 110 dodgei............................ 103

felinus............................ 105

hartshornianus...................... 105

nebrascensis....................... 105

vetus.............................. 105

sp................................ 103

Darton, N. II., on Monument Creek formation. ........................ 61

papers by..................... 11, 13, 14, 19

Dasypoda....................... 33, 43, 50, 52

Dasypodidæ........................... $\quad 31$

Davis, W. M., papers by ................. 10

Dawkins, W. B., papers by................ 10

Deep River, Mont., fauna of. ............ 114-115

Deep River sequence, fauna of...... 76-78, 114-115

homotaxis of .................... $76-78$

Deltatherium.......................... 101

fundaminis......................... 91

Depéret, Charles, correlation by .......... 8 8-9

Deposition, stages of, character of .......... $\quad 22$

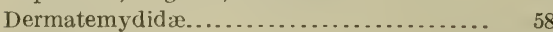

Desmathyus...................... 74,75,119 pinensis............................ 113

siouxensis........................ 113

sp ................................ 113

Desmatotherium...................... 102

guyotii.
101

alticuspis........................ 93

celatus................................. 93

Dibelodon............................ 120

humboldtii....................... 120

mirificus...................... 82, 83,120

præcursor....................... 120

tropicus.......................... 120

Diceratheriinæ............ 59, 64, 67, 68, 69, 75, 77

Diceratherium.... 61, 68, 70,72, 73, 74, 75, 108, 111,119

armatum......................... 108

cooki............................ 113

nanum.............................. 108

niobrarense........................ 113

sp............................... 113

Diceratherium zone, fauna of ....... $67-68,106-109$

homotaxis of..................... 64,67

figures showing . . . . . . . . . . $23,65,67$

Dichobunidæ. . . ......... 36, 57,95, 98, 99, 103, 106

Dicotylidæ ...... 59, 61, 63, $66,68,74,75,80,81,83,86$, $87,89,90,104,106,109,111,113,115,117,119,120$

Didelphodus.......................... 49, 101 absarokæ.......................... 93

Didelphyidæ............. 55, 59,61, 103, 105, 110

Didymictis......................... 46, 100

altidens. . . . . . . . . . . . . . . . . . . . . 49,93

haydenianus..................... 91

leptomylus......................... 93

protenus............................. 93

Dilophodon........................... 102

minusculus....................... 98

Dinictis........................... 110

bombifrons......................... 107

cyclops........................... 107

felina.............................. 105

fortis............................ 103

paucidens......................... 105

squalidens........................... 105

sp................................. 103

Dinoceras. See Uintatherium.

Dinocerata.................. ${ }^{47} 4,52,54,56,57$

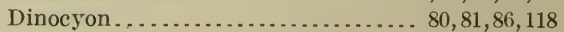

gidleyi.......................... 115

mæandrinus........................ 115

ossifragus.......................... 115

ursinus.......................... 115

Dinohyus...................... 72,74,108

hollandi........................... 113

Diplacodon........................... 102

elatus.............................. 99

emarginatus......................... 99

sp.............................. 99

Diplacodon zone, fauna of . . . . . . . . 55-57,98-100 homotaxis of . . . . . . . . . . . . . .

figures showing.................. 23,56

Dipodidæ........................... 107

Dipoides........................... 81,118

tortus.............................. 116

Dissacus........................... 35, 101

leptognathus........................ 93

navajovius......................... 91

saurognathus....................... 91

Dolichorhinus . .

cornutus........................ 54,57,99

sp................................. 99

Domnina crassigenis..................... 105

gradata.............................. 105 
l'age.

46

Dorcatherium aquaticum.

Douglass, Earl, papers by

$11,14,19$ 21,24

Drainage, changes in

96

Dromocyon vorax

Drummond, Mont., fauna near . . . . . . . . 106-109

Dryptodon............................ 102 crassus........................... 94

Earle, Charles, and Osborn, H. F., paper by. 12

Ectocion oshomianus.

Ectoconus. dil rigonus

Ectogảnus. gliriformis.

Edentata $78,82,83,85,86,87,89,90,97,102,114,119,120$

Elephantidæ.

$116,119,120$

Elephantinæ.

86,87

Elephas.

$82,83,87$ columbi.................. $85,86,87,88,89$ imperator.............. $79,83,84,85,86,87$ meridionalis....................... 83,85 primigenius................. $86,87,88,89$

Elephas imperator zone, fauna of.......... 83-84 homotaxis of . . . . . . . . . . . . . . . . . . .

Elotheriidæ.................... 54, 57, $66,68,69,74,75,77,104,106,108,111,113,119$

Elotheriin $x^{2 . . . . . . . . . . . . . . . . . . . . . . . ~} 61,63$

Elotherium.............. 59,67, 69, 70, 75, 108, 119 bathrodon...................... 108 calkinsi ............................ 108 coarctatum........................ 104 crassum..................... 104, 106, 108 imperator........................ 108 ingens......................... 106, 108 mortoni......................... 106 sp.......................... 104, 108, 113

Emydidæ............................ 58

Enhydrocyon................... 75, 111, 118 basilatus.......................... 107

crassidens......................... 112

sectorius......................... 107

stenocephalus...................... 107

Entelodon. See Elotherium.

Entelodontidæ. Sce Elotheriidæ.

Entelodontinæ........................ 61

Entomacodon angustidens................. 96 minutus............................. 96

Entoptychus.................... 68, 75, 110 cavifrons.......................... 107 crassiramis...................... 107 curtus............................. 112 formosus.......................... 112

lambdoideus....................... 107 minor................................ 107 planifrons......................... 107 rostratus.......................... 107 sperryi ............................. 107 Eobasileidæ................... 94, 97, 99, 102

Eobasileus................... 54,56,97,102 cornutus furcatus. galeatus. pressicornis sp.
Eobasileus zone, fauna of. homotaxis of.

Page. figures showing...

20, $53,54-55$ $22,53,54-55$ Eocene, distribution of, plate showing ..... 7,60 fauna of. .

33- $57,91-103$ range of . . . . . . . . . . . . . . . . 100-10s homotaxis of . . . . . . . . . . . . . . . . 33-5i records of....

Hocene, basal, falma of . . ..... 33-35,91-92, 100-103 homotaxis of . . . . . . . . . . . . . . . . 33-35

Eocene, lower, fauna of....... 35-50,92-95, 10()-103 homotaxis of . . . . . . . . . . . . . . . 35-50

Eocene, middle, fauna of . . . . . 43-54,95-98, 100-103 homotaxis of . . . . . . . . . . . . . . . . 43-54

Eocene, upper, fauna of . .......... 53-57,98-103 homotaxis of . . . . . . . . . . . . . . . . 53-57

Eocene-Oligocene correlation, progress of .... 31

Eohippus.............. 38,41,44,45,46, 47, 102 angustidens....................... 95

borealis......................... 95

craspedotus........................ 95

cristatus .......................... 38,95

cristonensis....................... 95

cuspidatus........................ 95

index ............................ 39,95

montanus........................ 95

pernix........................... 95

resartus.............................. 95

validus............................. 95

vassaciensis..................... 39,95

venticolus......................... 95

sp............................... 49

Eohippus zone. homotaxis of ............ .23

Eohyus distans...................... 94

robustus............................ 94

Eolian theory, history of ............... 27

Eotitanops....................... 44,45, 102

borealis..................... 44, 46, 48,95

brownianus..................... 46, 95

Eotitanops zone, homotaxis of ............ 23

Epigaulus.......................... 81,119

hatcheri......................... 116

Epihippus............................ 102

gracilis........................... 99

parvus............................. 99

uintensis . . . . . . . . . . . . . . . . . .... 99

Eporeodon................. 64, $68,75,78,111,119$

leptacanthus....................... 109

longifrons......................... 109

major............................. 109

occidentalis........................ 109

pacificus........................... 109

socialis............................ 109

trigonocephalus..................... 109

sp............................... 109, 113

Equidæ... 30, 38, 40, 41, 46, 52, 54, 57,61, 63, $64,66,67$, $68,74,75,76,78,80,81,83,85,86,87,89,90,95,98$, $99,102,104,106,108,111,113,115,117,119,120$

Equinæ............................... 86

Equus...................... $82,83,85,87,89,90$ excelsus......................... 83,84

stenonis........................... 83

Equus zone, fauma of ................. 85,86 homotaxis of ..................... 85

figure showing............... $\quad 82$ 
Page.

Erethizon......................... 87,88,90 dorsatus......................... 90

Erinaceidæ..................... 52,105,110

Erosion, retardation of ................. 21

Eschatius............................ 86

Esthonyx.................... 38,45,46,101 acer............................. 94

acutidens.......................... 94

bisulcatus.......................... 94

burmeisteri......................... 94

spatularius....................... 94

Eucastor............................ 118 tortus............................. 116

Euceratherium........................ 89

Eucrotaphus. See Eporeodon. jacksoni ...

Euhapsis............................... 75,118 brachyceps....................... 112 gaulodon........................... 112 platyceps.......................... 73

Eumys.............................. 110 elegans........................... 105

Euprotogonia......................... 40,102

Eurasiatic-American correlation, problem of. 29-30

European-American faunas, correlation of...

Euryacodon. lepidus.

Eusmilus. dakotensis

utypomys...

thomsoni.

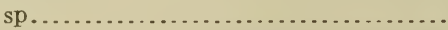

Evanston formation, section of, figure showing.

F.

$$
\text { F. }
$$

Fauna localities, location of, map showing... .

Felidæ......... 60,61,63, 66, 68, 77,80,83,85,89, $90,103,105,10 \bar{\tau}, 110,112,114,116,118,120$

Felinæ......................... 64,77,81,90

Felis....................... 80, $83,85,89,90$ canadensis........................ $\quad 89$

concolor.......................... 89

hillianus ....................... 83,120

Fiber ............................ 85,90

Ficus ................................... 78

Field work, character of ................ 19

Filhol, H., papers by.................... 10

Fissipedia............ 33,99,103,105,106-107-110

Flint Creek, Mont., fauna of ........... 114-115

Flood-plain theory, history of ............. 26-28

Florida, formations in, homotaxis of, figure showing......................

Formation, definition of..................

Formation names. form of.

Formations, mountains and plains, homotaxis of

Fort Logan, Mont., fauna near.

112-114

Fort Niobrara, Nebr., fauna near......... 115-118

Fort Union, Mont., section at, figure showing.

Fort Union formation, fauna of..

homotaxis of, figure showing.

Fowkes formation, homotaxis of, figure showing ............................

Furlong, E. L., papers by.... ............
Geolabis rh ynchæus .....

\section{G}

Page.

Geological Survey, rulings of, on formation names..................... 8

Geomyidæ........................ 61 $66,68,75,99,101,107,110,112,114,116,119$

Geomys........................ 85, 90, 119

bisulcatus......................... 116

sp................................. 114

Gering formation, homotaxis and fauna of... 73

homotaxis of, figure showing......... 72

Gidley, J. W., paper by ................. 14,21

Gidley, J. W., and Matthew, W. D., paper by . 15

Gilbert, G. K., papers by .............. 10,14

Gilbert, G. K., and Hall, J., paper by ...... 17

Glacial epoch, homotaxis and fauna of...... $86-90$

Glyptodontia.................... 82, 83,86

Glyptodontidæ....................... 120

Glyptosaurus......................... 47,49

Glyptotherium ........................ 83

texanum......................... 120

Glyptotherium zone, fauna of ........ 82-83, 120

homotaxis of ..................... 82

figure showing ............. 23, 65, 82

Gomphotherium. See Trilophodon.

Goniacodon ........................... 101

levisianus........................ 91

Gravigrada..................... 78, 82, 86, 87

Great Plains, dry-land conditions in........ $57-58$

Green River formation, homotaxis of, figure showing..................... $\quad 39$

Gymnoptychus ....................... $\quad 110$

minimus......................... 104

minutus.......................... 104,105

trilophus.......................... 105

H.

Hall, J., and Gilbert, G. K., paper by...... 17

Hapalodectes........................ 45, 101

leptognathus...................... 93

sp............................... 93

Haploceras. . . . . . . . . . . . . . . . . . . . . 87,89

Haploconus........................... 102

corniculatus.................... 92

lineatus............................. 92

Haplodontidæ...................... 64, 66, 68

Harpagolestes......................... 101 macrocephalus.................... 96

uintensis.......................... 98

sp................................ 98

Harris, G. P., and Dall, W. H., paper by.... 13

Harrison, Nebr., fauna near............. 112-114

Harrison formation, homotaxis and fauna of . 73-74 homotaxis of, figure showing......... 72

Hatcher, J. B., papers by............ 14, 17, 19

Haworth, E., paper by ................... 15

Haworth, E., and Beede, J. W., paper by... 17

Hay, O. P., on Great Plains.............. 57-58 paper by......................... 11

Hay, R., paper by .................... 15

Hayden, F. V., on Washakie basin........ 53 on Wind River formation........... 44-45, 47 papers by........................ 11

Helalotes.......................... 99, 102 boöps............................ 98 
Helaletes, nanus...................... $\quad \begin{array}{r}\text { Page. } \\ 98\end{array}$ sp............................... 98

Helaletinæ........................ 41, 54

Helohippus........................... 102

Helohyus............................ 103 etsagicus........................... 95

lentus............................. 98

plicodon......................... 98

validus............................ 98

sp ................................. 98

Helotherium.......................... 102

Helvétien étage, homotaxis and fauna of.... $76-78$

Hemiacodon......................... 100 gracilis........................... 95

pygmaeus.......................... 95

Hemipsalodon grandis................ 103,110

Hemithlæus........................... 102 kowalevskianus.................... 92

Heptodon..................... 38, 41, 46, 102 calciculus......................... 94 posticus........................... 94 singularis............................ 94 ventorum........................ 94 sp.................................. 99

Herbivora............................... 86

Hesperomys.......................... 118 loxodon ........................... 116

Hesperhys............................ 119 vagrans. . . . . . . . . . . 115

Heteromeryx ......................... 111 dispar........................... 104 transversus......................... 104

Heteromyidæ....................... 57,119 sp................................. 112

Hills, R. C., papers by . ................. 11

Hipparion . . . . . . . . . . . . . . . . . . . . 79,83

Hippotheriinæ. . ....................... 78

Holarctica, invasion from.............. 35-36

Hollick, Arthur, on Mascall flora.......... 78

Homacodon ......................... 98, 103

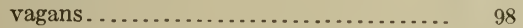

sp................................. 98

Homacodontidæ. . . . . . . . . . . . . . . . . . . 57,98 Homo............................. 88,89,90 Homogalax. See Systemodon.

Hoplophoncus........................ 110

cerebralis.......................... 107

davisi............................ 107

insolens.......................... 107

occidentalis....................... 105

oreodontis......................... 105

primævus.......................... 105

sp............................. 105

Horizons, phases of, homotaxis and faunæ. . . 33-90 time correlation of................... 29-32

Horsetail Creek, Colo., fauna of. . . . ....... 103-104

Huerfano formation, fauna of. ........ 48-50,95-98 homotaxis of. ..................... 48-50

figure showing.................. 23

Huerfano Park, Colo., deposits of .......... 48 fauna of........................... 92-95 section of, figure showing............. 23

Hyænidæ............................ 64

Hyænodon . . . . . . . . . . . . . . . . . . . 59, 103,110 crucians.......................... 105 cruentus
Hyænodon horridus.................. Page. leptocephalus....................... 105 montanus......................... 105 mustelinus......................... 105 pauciden s . . . . . . . . . . . . . . . . . . . 105

Hyænodontidæ............... 40,45, 46, 52, 54, $57,60,61,62,63,666,93,96,101,103,105,110$

Hyohippus....................... . 78, 82

Hyomeryx......................... 103

breviceps......................... 100

Hyopotamus................. 59, 61, 62, 64, 111 americanus....................... 104

brachyrhinchus.................... 109

rostratus......................... 106

Hyopsodontidx........ 46, 52, 59, 92, 93, 96, 99, 101

Hyopsod us. . . . . . . . . . . . . . . . 38, 40, 44, 45, 47, 101 browni......................... 93

gracilis.......................... 99

jacksoni.......................... 93

laticuneus......................... 93

lemoinianus...................... 93

marshi........................... 96

minor........................... 93

minusculus....................... 96

miticulus......................... 93

paulus............................. 96

powellianus...................... 93

simplex........................ 93

uintensis.......................... 99

wortmani........................ 93

sp........................... 49,93,96

Hypertragulidæ . . . . . . . . . . . 57, 61, $C 3,64,68,74$,

$75,77,100,103,104,106,109,111,114,120$

Hy pertragulus. . . . . . . . . . . . . 70, 75, 111, 120 calcaratus....................... 106,114

hesperius......................... 109

ordinatus....................... 114

planiceps......................... 109

sp................................ 109

Hypisodus. . . . . . . . . . . . . . . . . . 74,111

minimus......................... 106

Hypohippus. . . . . . . . . . . . . . . . 80, 81, 119

affinis.......................... 117

equinus......................... 115

osborni........................... 115

sp............................ 115, 117

Hyrachyus........................ 49, 102

agrarius. . . . . . . . . . . . . . . . . . . . 97

bairdianus....................... 97

crassidens......................... 97

eximius.......................... 97

imperialis....................... 97

intermedius..................... 97

paradoxus......................... 97

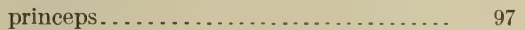

priscus......................... 99

sp.................................... 97

Hyracodon......................... 111

arcidens......................... 105

major............................ 105

nebrascensis....................... 105

planiceps........................ 105

priscidens.......................... 104

sp.................................. 108

Hyracodontidæ................... 52

$54,57,61,63,99,102,104,105,108,111$ 
Page.

Hyracoidea.

Hyracops.

Hystricomorpha. 88,89

I.

Icticyon $\mathrm{sp}$.

114

Ictops.

acutidens.

bullatus.

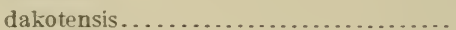

intermedius.

major.

montanus.

porcinus

tenuis.

thompsoni

Indrodon.

malaris.

110

103

105

105

103

103

103

105

103

103

Insectivora...................... $33,34,40,45$

$3.5,101$ $46,52,56,58,59,61,63,64,75,90,92,93$, $95,96,99,101,105,107,110,112,114,118$

Irving, J. D., paper by.

15

Ischyrocyon......................... 80, 118 hrænodus. .

115

Ischyrom yidæ.

$61,63,66,94,97,99,101,104,105,110$

Ischyrom $5 \mathrm{~s} . \ldots \ldots \ldots \ldots \ldots \ldots \ldots \ldots \ldots .61,110$

cristatus........................... 105

typus.............................. 105

veterior ........................... 104

Isectolophus .......................... 102

annectens . . . . . . . . . . . . . . . . . . . . . . 99

latidens. ......................... 98

modestus. . . . . .

Ithygrammodon........................ 103

cameloides.

John Day, Oreg., fauna of.

106-109

John Day formation, fauna of....... 64-69, 106-111

homotaxis of .................. 22, 64-69

figures showing. . . . . . . . . . . . 23, 65,67

Johnson, W. D., papers by

\section{K.}

King, on voleanic ash .

Knight formation, homotaxis of, figures showing..

Knowlton, F. H., paper by.

L.

Lacertilia

Lacustrine theory, history of ............. 26-28

Lambdotherium.......... 41, 44, 45, 46, 47, 48, 102 popoagicum................. 46, 47, 49,95 primærum...................... 38, 48

Lambdotherium zone, fauna of.... 43-47, 49, 92-95 homotaxis of ................ 22, $43,4 \overline{7}, 48$ figures showing.............. 23, 38, 44

Laramie formation, homotaxis of, figure showing.................... $\quad 39$

Laramie Peak, Wyo., fauna near........ 112-114 Laurus............................ is Leidy, J.. on Loup Fork fauna........... \$3

Leidy, J., and Lucas, F. A., paper by ....... 15 Leporidæ.... 61, 66, 68, 104, 105, 108, 110, 113, 116, 119

\section{Leptaceratherium . \\ trigonodon.}

Page.

111

Leptaretus.

104,105

Leptauchenia..... $64,66,69,70,72,73,75,78,111,119$

decora.

73,113

major.

113

nitida....................... 73,113 sp......................... 106, 109.113

I.eptauchenia zone. fauna of . ....... 63, fit , 106-109 homotaxis of ..................... 63 figure showing............. 23, $(52,64,65$

Leptictidæ..... . 45, $46,52,611,93,9 \nmid, 101,103,105,110$

Leptictis............................ 110 haydeni........................... 105

Leptochœridæ. . . . . . . . . . . . . 63, 69, 104, 10ti, 109, 111

Leptochœrus.......................... 111

gracilis.......................... 106

lemurinus.......................... 106

robustus.......................... 106

spectabilis....................... 106

sp................................. 109

Leptomeryx......................... 111

esulcatus........................ 104

evansi........................... 106

transmontanus...................... 109

sp ............................. 104, 106

Leptoreodon......................... 103

marshi.......................... 100

Leptotragulus......................... 103, 111

lævis............................. $\quad 100$

proarus........................... 100

profectus......................... 104

sulcatus........................ 100

sp................................ 100

Lepus....................... $68,75,85,90,110$

ennisianus........................ 108

macrocephalus...................... 113

primigenius........................ 113

sp.............................. 116

Ligurien étage, homotaxis and fauna of..... 54

Limnenetes........................... 111

anceps........................... 104

platyceps......................... 104

Limnocyon......................... 45,100

verus........................... 96

sp.......................... 93,96, 98

Limnohyops........................... 102

diaconus......................... 98

laticeps............................ 98

Little White River. S. Dak., fauna of ...... 115-118

Loomis, F. B., on Bighorn Basin ........... 41 on Wind River formation........... $\quad 47$ papers by...................... 11, 15

Lophiodon oregonensis . ................. 108

Lophiodontidæ...... 36, $38,40,41,46,52,54,57,61$, $63,94,95,99,102,104,105,111$

Loup Fork fauna. identity of........... $79, \$ 3-84$

Lower Brule Creek S. Dak.. fauna of...... 105-106

Loxolophodon....................... 54 semicinctus...................... 54

Loxolophus.......................... 101 attenuatus............................ 91

hyattianus...................... 91

priscus......................... $\pi$

Lucas, F. A., and Leidy, J.. paper by....... 15 
Page.

Ludien étagc, homotaxis and fauna of. 54,57. 60-61 Lutćtien étage, homotaxis and fauna of ..... 43-53 Lutra......................... 80,85,118 pristina... ....................... 116

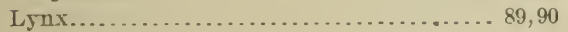

\section{II.}

Machærodus.......................... 118

augustus.......................... 116

catocopis........................ 116

crassidens ......................... 116

maximus........................... 118

Machærodontin $æ . . . . . . .60,61,63,81,86,87,89,90$

McMaster, J. B., paper by ............... 12

Macrotherium........................ 69

Madison Valley, Mont., fossils of.......... 11j-118

Mammalian life, phases of ............... 20

Manteoceras........................ 53,102 manteoceras......................... 98

ultimus........................... 99

sp.................................. 99

Marsh, O. C., papers by................ 10

Marsilea............................ 78

Marsupialia............. 33, 55, 59,61, 103, 105, 110

Martin Canyon, Colo., fauna of.... 106-109,112-114

Mascall, Oreg., fauna of.................. 114, 115

Mascall formation, homotaxis and fauna of. $22,64,78$ homotaxis of, figure showing........... 23

Mastodon........................ 69, 83, 87,89 americanus........................ 86 mirificus......................... 83,84

Mastodontidx......................... 81

Matthew, IV. D., correlation by ......... 8, 29.69 on Brule clay.................... 62, 63 on faunal persistence................. $\quad 42$ on Great Plains deposition.............. $\quad 27$ on Miacidæ......................... 52 on Rosebud beds.................... 75 papers by ...................... 11, 15, 17

Matthew, W. D., and Gidley, J. W., paper by .........................

Meek, F. B., and Hayden, F. V., on Loup Fork beds.

Megacerops.

nis........................

bicornutus.........................

brachycephalus.....................

coloradensis..

dispar..

marshi

robustus.

selwynianus.

tichoceras.

Mcgalictis ferox............................ 112

Megalonychidx.................. 114, 119, 120

Megalonyx................... 82,83,87,88,89 leptostoma...................... 120

Meniscomys.................... 65,75, 110 sp.............................. 112

Meniscotheriidæ..................... 40, 94, 102

Meniscotherium..................... 102 chamense......................... 94 tapiacitis.......................... 94 terrarubræ..
89,90

Mercer, II. C., paper by.................. 18

Merriam, J. C., on volcanic ash........... 25 papers by...................... 15, 18, 19

Merychippus................... $78,79,80,119$ calamarius ........................ 117

campestris.......................... 115

insignis........................... 117

isonesus........................... 115

labrosus.......................... 115

paniensis.......................... 115

sejunctus......................... 115

seversus......................... 115

sphenodus....................... 115

Merychippus zone, homotaxis of.......... 64

Merychyus...... $69,70,72,74,75,78,80,81,113,119$

elegans....................... 113, 117

harrisonensis.................... 113

major........................... 117

medius............................ 117

pariogonus........................ 115

smithi.. $11 \tilde{0}$

sp........................... 115, 11 .

Merycochœrus........ $69,70,72,74,75,78,80,81$ cenopus......................... 117

proprius.......................... 115

rusticus....................... 115

sp........................... 113,117

Merycochœrus zone, homotaxis of, figures showing .......... 23, 64, $65,70,72,82$

Merycodontinæ........ $7,80,81,86,114,115,118,120$

Merycodus..................... $77,80,81,120$

agilis. . ........................... 118

furcatus......................... 118

necatus........................... $\quad 118$

osborni............................ 115

ramosus............................ 118

tehuanus.......................... 118

Merycoides........................... 119

cursor.......................... 113

Merycoidodon. See Oreodon.

Mesatirhinus........................ 51

megarhinus...................... 52, 53,54

Mesocyon.................... 68, 75, 110,118

brachyops........................ 107.

coryphæus...................... 106

drummondanus...................... 107

josephi.......................... 106

robustus......................... 112

sp............................. 112

Mesodectes........................... $\quad 110$

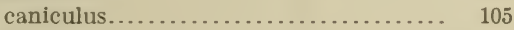

Mesogaulus........................... $\quad 119$

ballensis........................ 114

Mesohippus........................ 111 acutidens. . . . . . . . . . . . . . . . . 68,108 assiniboiensis...................... 104 bairdii......................... 106

brachylophus .................... 108

brachystylus.................... 104,108

celer.............................. 104

equiceps .......................... 108

euloplius ............................. 106

exoletus........................... 106

hypostylus....................... 104 
Mesohippus, intermedius ............... $\quad 108$

latidens............................ 104

longicristis...................... 108

montanensis....................... 104

obliquidens........................ 106

precocidens......................... 104

planidens............................ 104

propinquus ........................ 104

proteulophus...................... 104

stenolophus .......................... 104

Mesonychidæ..................... 33,34,35, $37,40,45,46,52,54,57,90,91,93,96,98,101$

Mesonyx obtusidens

sp.......................................

98

Mesoreodon ................... 72,73,75,119 chelonyx......................... 113

intermedius....................... 113

latidens.......................... 113

megalodon .......................... 113

Mesotapirus. See Colodon.

Messinien étage, homotaxis and fauna of... 80

Metacheiromyidæ.................... 97,102

Metacheiromys..................... 50,52,102

dasypus........................... 97

marshi........................... 97

tatusia......................... 97

sp............................... 97

Metamynodon....................... 62,111

platyfrons.......................... 105

sp............................. 99,104

Metamynodon sandstones, fauna of......... 63

homotaxis of ..................... 62

figures showing........... 22,62,64,65

Miacidæ .. 35, 40, 42, 46, 52, 54, 57, $90,91,93,96,98,100$

Miacis........................... 46,100 hargeri. .

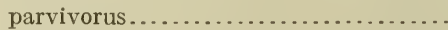

sylvestris.

uintensis.

vulpinus.

washakius.

sp................................ 93,96

Microclænodon ........................ 101

assurgens.......................... 91

Micropternodus ...................... 110

borealis.......................... 103

Microsorex........................... 90

Microsus.......................... 98, 103 cuspidatus........................ 98

Microsyopidæ................ 46, 52,93, 95, 100

Microsyops........................ 49, 100 annectens...

elegans...

schlosseri.

scottianus.

typus...

Microtus.

Miocene, distribution of, plates showing ..... 7,60

fauna of.

$70-81,112-120$

homotaxis of.

$70-81$

figures showing.................... 64,65

Miocene, lower, fauna of .... 70-75,112-114, 118-120 homotaxis of . . . . . . . . . . . . . . . .

figure showing.

65
Miocene, middle, fauna of.... $76-78,114-115,118-120$ homotaxis of ..................... $76-78$ figure showing.................. 65

Miocene, upper, fauna of........... $79-81,115-120$ homotaxis of . . . . . . . . . . . . . . figure showing.................. 65

Mioclænus........................... 34, 101 acolytus........................... 92

inæquidens....................... 92

lemuroides......................... 92

lydekkerianus...................... 92

turgidunculus..................... 92

turgidus ............................ 92

Miohippus.......................... 111

anceps........................... 108

annectens..................... 108, 113

condoni.......................... 108

crassicuspis....................... 108

equiceps......................... 113

gidleyi........................... 108

validus......................... 108

Miolabis ..................... 66, 74, 78,120

transmontanus....................... 115

Mixodectes ............................ . 35, 101

crassiusculus.................... 92

pungens.......................... 92

Mixodectidæ.................. 34, 92, 93, 95, 101

Modernized mammals, invasion of .......... 35 orders of......................... 33

Modernization, first stage of . . . . . . . . . . . 35-42 second stage of.................... . 57-69 third stage of ..................... 84-90

Mollusca............................ 66

Monroe Creek, Nebr., fauna near......... 112-114

Monroe Creek formation, homotaxis and fauna of ................... 73 homotaxis of, figure showing.......... $\quad 72$

Montana, fauna of......... 91-92, 98-100, 103-109 formations of, homotaxis of........... 22

figure showing................... 23, 65

Monument Creek formation, description of... 61

Moropus................... 72, $74,111,113,119$ distans.......................... 108

elatus........................... 113

oregonensis........................ 108

senex............................. 108

sp............................... 115

Mountain Region, deposits of, correlation of . 31-32 erosion in......................... 21 homotaxis of, with plains deposits...... 22

figures showing................. 23 mammalian life of .................. 20,22

Tertiary history of................. 19-25

Mountains, persistence of............... 24

Multituberculata.................. 33, 35, 40, 91

Muridæ............. 63, 66, 105, 107, 110, 116, 119

Mustela........................ 80, 90,118 americana......................... 90

minor............................ 116

ogygia........................... 114

parviloba........................... 114

Mustelidæ........... $60,61,63,66,74,80,83,85,89$, $90,103,105,107,110,112,114,116,118,120$

Mylagaulodon ....................66, 68, 110 angulatus.......................... 107 
Page.

Mylagaulidæ $77,78,80,81,114,116,119$

Mylagaulus. lævis... $78,81,119$ monodon paniensis. 114,116 pristinus. 116 proximus sesquipedalis.

116

Mylodon. 116 sp.

$82,83,85,87,89$ yylohyus.

Myotis.

90

\section{N.}

Nanohyus. See Ictops.

Nanomeryx. caudatus.

Nebraska, fauna of .................. 103-109 formations in, homotaxis of. figure showing. Oligocene and Miocene in, map showing.

Neohipparion $79,80,83$, affine calamarium

dolichops.

eurystylus

gratum...

ingenuum

lenticularis.

montezumæ

niobrarense.

occidentale.

peninsulatum.

plicatile.

princeps.

rectidens.

relictum.

retrusum.

sinclairii.

speciosum

whitneyi .

sp.........

americanus.

molestus

Neotoma.

formation of, homotaxis of

$$
\text { figure showing. }
$$

Nimravus confertus.

.. 23,65

debilis............................ 107

gomphodus....................... 107

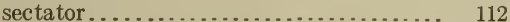

North Boulder Creek, Mont., fauna of.... 114-115

North Dakota, fauna of.................. 106-109

Notharctidæ.............. 46,52,92,95, 98,100

Notharctus........................ 46,47,100

affinis........................... 95

anceps............................ 95

cingulatus........................ 92

minutus........................... 93

nunienus.......................... 92

palmeri.......................... 92

rostratus.......................... 95

tenebrosus.
Notharetus, tyrannus............. Page.

uintensis.......................... 98

venticolus........................ 92

sp............................... 95

Nothocyon.............. $68,73,74,75,110,118$

annectens....................... 112

geismarianus...................... 106

gregorii........................... 112

latidens......................... 106

lemur......................... 106,112

vulpinus........................ $\quad 112$

Notostylops zone, mammals of ........... 33

Nototherium........................ 88

Nyctilestes........................... 101

Nyctitherium ........................ 101

priscus........................... 96

serotinus........................ 96

velox........................... 96

O.

Odocoileus................... $86,87,88,89,90$

Ogalalla formation, fauna of....... 79-81,115-118 homotaxis of .................... 79-81

Olbodotes........................... 101

Oligobunis.................... 66,75,110,118

crassivultus...................... 107

lepidus.......................... 112

sp............................. 105

Oligocene, distribution of, plates showing... 7,60 fauna of .................. 57-69,103-111 range of .................... 110-111 homotaxis of .................... $57-69$ figures showing.................. 64,65

Oligocene, lower, fauna of.... 60-61,103-104,110-111 homotaxis of .................... 60-61 figure showing.................. 65

Oligocene, middle, fauna of .. 62-63,105-106,110-111 homotaxis of ..................... 62-63 figure showing.................. 65

Oligocene, upper, fauna of . . . . . . . 63-69,106-111 homotaxis of .................... $63-69$ figure showing.................. 65

Oligocene-Eocene correlation, progress of..... $\quad 31$

Oligocene-Pleistocene correlation, progress of. 31-32

Oligotomus............................ 102

Omomys............................ 100

ameghini......................... 95

carteri.......................... 95

minutus......................... 93

pucillus........................... 95

Onychodectes......................... 102

rarus............................. 92

tisonensis......................... 92

Oödectes........................ 46, 52,100 herpestoides...................... 96 pugnax.......................... 96 sp.................................. 96

Opisthotomus. See Phenacodus.

Oregon, fauna of ..................... 106-109 formations of, homotaxis of.......... 22, 64 figure showing. . . . . . . . . . . $23,65,67$

Oreodon............................. 67 affinis............................ 104

bullatus......................... 104, 106

coloradensis...................... 106

culbertsoni......................... 106 
Oreodon, graeilis

hybridus.

macrorhinus.

104

periculorum.

106

Oreodon zone, fauna of . . . . . . . 62-63, 105-106

homotaxis of.

figure showing ............. 23,62,64,65

Oreodontidæ........................ 63 , $64,66,68,69,73,74,75,78,80,81,82,100$, $103,104,106,109,111,113,115,117,119$

Oreodontinæ........................ 57,61

Orohippus...................... 49, 52,102

agilis............................ 98

ballardi........................... 98

cinctus......................... 98

major.

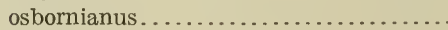

procyoninus.

pumilus.

sylvaticus

uintanus.

(1) fauna of . .......... 50,95-98

homotaxis of.................. $22,50-53$

figures showing.............. 23, 51

Oromeryx............................ 103

plicatus.......................... 100

Orotherium.......................... 102

Osborn, H. F., on divergent evolution...... 42

on Great Plains deposition............ $\quad 27$

papers by ................... 10,11, 12, 16

Osborn, H. F., and Earle, Charles, paper by . 12

Osborn, H. F., and Wortman, J. L., paper by. 12

Ovibos............................... 87,89

Ovinæ............................. 86,89

Oxyacodon............................. 101

agapetillus....................... 92

spiculatus.......................... 92

Oxyænа......................... 38,45, 100

forcipata....................... 93

huerfanensis . . . . . . . . . . . . . .... 49, 93

lupina............................. 93

morsitans........................ 93

sp................................ 93

Oxyænidæ. $37,40,45,46,48,52,54,57,93,96,98,100$

Oxyænodon .

dysclerus.......................... 98

dysodus......................... 98

Oxyclænidæ.................. 33, 34, 35, 91, 101

Oxyclænus........................... 101

cuspidatus....................... 91

simplex.......................... 91

Oxydactylus ...................... $72,74,78,120$

brachiceps....................... 114

longipes........................... 114

P.

Pachyæna......................... 45, 101

gigantea......................... 93

intermedia..................... 93

ossifraga........................ 93

Paciculus............................. $\quad 110$

insolitus......................... 107

lockingtonianus..................... 107

Palæarctomys....................... 118

macrorhinus ...................... 116

montanus. . ......................... 116

vetus............................ 116
Page.

Palæictops ..................... 38, 45, 46, 101

bicuspis.......................... 93

Palæolagus............................ 110

agapetillus......................... 108

brachyodon....................... 104

haydeni........................... 105

intermedius ....................... 108

temnodon......................... 104

turgidus......................... 105

Palæomeryx....................... $77,78,80$

americanus..................... 118

antilopinus...................... $\quad 115$

borealis............................ 115

teres............................. 118

trilateralis........................ 118

sp ........................... 115, 118

Palæonictidæ................. 40, 42, 46, 93, 100

Palæonictis......................... 100

occidentalis...................... 93

Palæosinopa...................... 45, 101

didelphoides....................... 93

veterrima........................ 93

Palæosyopinæ sp....................... 98

Palæosyops....................... 49, 54, 102

borealis....................... 44, 45, 51

fontinalis........................ 98

humilis.......................... 98

major............................ 98

paludosus........................ $\quad 98$

robustus........................... 98

Panochthus........................... 83

Panolax........................... 118

sanctæfidei.......................... 116

Pantolambda......................... 35,102

bathmodon....................... 92

cavirictus......................... 92

Pantolambda zone, fauna of ........ 34-35, 91-92

homotaxis of .................... 34

figure showing.................. 23

Pantolambdidæ................. 35, 40,92, 102

Pantolestes.......................... 101

longicaudus..................... 96

sp................................. 96

Pantolestidæ............. 45, 46, 52, 92, 93, 96, 101

Paradaphænus....................... 110 cuspigerus........................ 106

transversus........................ 106

Paradoxodon.......................... 101

rutimeyeranus.................... 91

Parahippus............. 70, 72, 74, 75, 78, 80, 119 avus............................... 115

brevidens....................... 115

cognatus.......................... 117

coloradensis. . . . . . . . . . . . . . . . . 115

crenidens....................... 113,115

nebrascensis...................... 113

pawniensis......................... 115

sp............................. 113, 115

Parahyus ............................ 103

aberrans............................ 95

vagus.............................. 95

Paramylodon ......................... 85, 87

Paramys........... 38, 40, 46, 49, 50, 57, 59, 61, 101

atwateri.......................... 94

bicuspis........................... 94

copei............................ 94 
Paramys, delicatior. delicatissimus.

delicatus.

excavatus.

leptodus.

major

primævus

quadratus

sciuroides.

uintensis

sp.......

cameloides.

primævus .

sternbergi

Page.

Parictis primævus.

Passalacodon. littoralis.

Patriofelis.

coloradensis

ferox

tigrinus.

ulta.

sp.

Pawnee Creek, Colo., fauna of

Peale, A. C., on volcanic ash

Pecora.

Pelycodus.

$38,40,44,46,47,100$

frugivorus.

jarrovii

tutus.

68,109

107

101

96

$45,50,100$

96

50,96

93

50,96

49

114-115

24

76,77

sp............................. 92,95

Pentacodon.

34,101

inversus.

92

Peraceras...................... $79,80,81,119$ superciliosus.

116

Peraceras zone, fauna of ........... $81,115-118$ homotaxis of .................... $\quad 80$

Peratherium......................... 110

alternans.......................... 105

comstocki...................... 46, 93

fugax ............................ 105

huntii........................... 105

marginale......................... 105

pygmæum....................... 105

scalare............................ 105

titanelix.......................... 103

tricuspis ........................ 105

Perchœrus............................. 111

lentus............................ 106

nanus.......................... 109

osmonti.......................... 109

platyops.......................... 109

pristinus......................... 109

probus.............................. 106

robustus......................... 109

rostratus........................... 109

socialis............................ 109

subæquans....................... 109

trichænus........................ 109

sp................................ 109

Periptychidæ................... 33, 35, 92,102

Periptychus......................... 102

carinidens........................ 92

coarctatus......................... 92

rhabdodon......................... 92
Page.

Perissodactyla .. 33, 36, 38, 40, 41, 42, 46, 52, 53, 54, 55, $56,57,58,59,60,61,62,63,64,66,67,68,74,75$, $77,80,81,85,86,87,89,94-95,97-98,99,102,104$, $105-106,108,111,113,114-115,116-117,118,120$

Peromyscus..................... 90, 110,119

loxodon ......................... 116

nematodon...................... 107

parvus........................... 107

Peterson, O. A., papers by ................ 16

Phenacocœlus.................... 73, 74, 119

typus......................... 74,113

Phenacodontidæ..... 33, 35, 40, 41, 42, 45, 92, 94, 102

Phenacodus.................. 38, 40,44,45,102

astutus........................... 94

brachypternus................... 94

flagrans......................... 94

hemiconus....................... 94

macropternus ..................... 94

nunienus......................... 94

primævus......................... 39,94

sulcatus......................... 94

wortmani ..................... 49, 94

sp................................ 94

Philotrox......................... 68, 110

condoni......................... 107

Phlaocyon .......................... 118

leucosteus....................... 112

Pipestone Creek, Montana, fauna of ...... 103-104

Pithecistes decedens..................... 115

emydinus ......................... 115

incisivus......................... $\quad 115$

simus........................... 115

Plagiaulacidæ..................... 34, 91, 100

Plains Region, deposition in............. 26-28

deposits of, correlation of . . . . . . . . . . 31-32

erosion in ........................ 21-22

homotaxis of, with mountain deposits... 22

figures showing................. 23

mammalian life of ................ 20, 22

Tertiary history of ............. 19-23, 26-28

Tertiary topography of ............... 28

Planus.............................. $\quad 78$

Platygonus .................. 83, 85, 87, 88, 89

bicalcaratus...................... $\quad 120$

striatus.......................... 117

texanus.......................... 120

Pleistocene, distribution of, plate showing... 7

homotaxis and fauna of.............. 83-90

homotaxis of, figure showing.......... 65

Pleistocene, lower, homotaxis and fauna of. . 83-86

Pleistocene, middle, homotaxis and fauna of. $86-90$

Pleistocene-Oligocene correlation, progress of. $31-32$

Pleurolicus............................ $\quad 110$

diplophysus.................... 107

leptophrys ........................ 107

sulcifrons......................... 107

Pliauchenia ................ 79, 80, 81, 83, 120

humphreysiana.................. 117

minima......................... 117

spatula.......................... 120

vera............................ 117

sp......................... 117, 120

Pliocene, distribution of, plate showing..... $\quad 7$

gaps in.......................... 32

fauna of ................. 81-84, 115-118

homotaxis of ..................... $81-84$

figure showing................ 65 
Page.

Pliocene, middle, fauna of .............. $82-83,120$ homotaxis of ..................... 82-83

Pliocene, upper, homotaxis and fauna of.... 83-84

Pliohippus .............................. $\quad 119$ simplicidens....................... 120 supremus........................ 81

Pliolophus............................ 49

Poatrephes............................ 119

paludicola........................ 115

Poëbrotherium ....................... 64,111

eximium .......................... 106

labiatum........................ 106

wilsoni........................... 106

sp.............................. 114

Polymastodon....................... 100

attenuatus......................... 91

fissidens.......................... 91

selenodus....................... 91

taoensis............................ 91

Polymastodon zone, fauna of. ........ 33-34,91-92 homotaxis of ..................... 33

figure showing.................. 23

Pontien étage, homotaxis and fauna of..... 79-81

Port Kennedy cave, Pa., fauna of........... 87-88

Post-Cretaceous, homotaxis and fauna of .... 33-35

Potamotherium ........................ $\quad 80$

lacota............................ 116

lycopotamicum..................... 114

robustum ........................... 116

Potter Creek cave, California, fauna of ...... 88-89

Preptoceras.......................... 89

Primates ........................... 33, 36, $38,40,52,56,57,59,88,92-93,95,98,100$

Proboseidea ...................... 33,69,76, $77,78,80,81,82,83,86,89,90,116,119,120$

Procamelus ..................... 79, 80,81, 120 gracilis........................... 117

lacustris........................ 117

leptognathus....................... 117

madisonius........................ $\quad 117$

major........................... 117

minimus......................... 117

minor ............................. 117

occidentalis ......................... 117

prehensilis.......................... 117

robustus ........................ 115,117

Procamelus zone, fauna of........ . 79-80,115-118

homotaxis of .................... 64,79

Procynodictis vulpiceps.................. 99

Procyon.............................. 90

Procyonidæ......... 46, 64, $80,89,90,112,116,118$

Proglires................................ 92

Promerycochœrus.... 30,68,69, 70,73; $74,75,111,119$ carrikeri....................... 72,113 chelydra ......................... 109

grandis............................ 113

hatcheri......................... 113

hollandi........................... 113

leidyi.............................. 109

macrostegus........................ 109

minor ............................... 109

montanus.......................... 115

obliquidens........................ 115

superbus. ........................... 109

vantasselensis................... $72,74,113$

sp............................. 113
Page.

Promerycochœrus zone, fauna of ........ 68-69,

$73-75,106,109,112-114$

homotaxis of .............. 23,64,68,70-71

figures showing.......... $64,65,67,70,72$

Pronomotherium...................... 80,119

altiramis......................... 117

laticeps.......................... 115

Proscalops............................ 110

miocænus ....................... 107

Prosciurus ............................ 110

ballovianus...................... 107

jeffersoni........................... 103

relictus......................... 105

vetustus......................... 103

wortmani. . . . . . . . . . . . . . . . . . . 107

Prosthennops .................... 80,81,119

crassigenis........................ $\quad 117$

serus............................. 117

Protagriochœrus........................ 103

annectens.......................... 100

Protapirus.......................... 68,111

obliquidens........................ 108

robustus......................... 108

simplex......................... 106

(Tapiravus) validus............... 20,108

Proterix........................... $\quad 110$ loomisi............................ 105

Protoceras....................... 64,74,111

celer............................ 109

comptus.......................... 109

nasutus........................... 109

Protoceras zone, fauna of ........... 63,106-109

homotaxis of ...................... 63

figure showing............. 62,64,65

Protoceratidæ........................ 120

Protochriacus. See Loxolophus.

Protogonodon.......................... 102 pentacus.......................... 92 stenognathus........................ 92

Protohippus................. 79,80,81,83,119

castilli.......................... 117

cumminsii....................... 120

fossulatus....................... 117

gracilis............................. 117

interpolatus....................... 117

minutus........................... $\quad 120$

mirabilis........................... 117

pachyops.......................... 117

parvulus......................... 117

perditus........................... $\quad 117$

pernix .......................... 117

phlegon........................... 120

placidus........................... 117

profectus........................... 117

robustus.......................... 117

simus............................ 117

spectans......................... 117

supremus........................ 117

Protohippus zone, fauna of...............

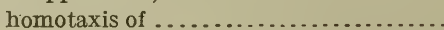

figure showing ................. 65,82

Protolabis .......................... 78, 120

angustidens......................... 115

heterodontus...................... 115

longiceps........................... 115

montanus.......................... 117

Protomeryx..............64, $70,72,73,75,120$ 
Page.

Protomeryx, cedrensis. .

halli.

sp.

114

114

114

Protoptychus

57,101

hatcheri

Protoreodon.

minor.

paradoxicus.

parvus.

pumilus..

Protorohippus.

Protoselene..

opisthacus.

Protosorex...

crassus.

Protylopus. petersoni.

Proviverrinæ

Prunus

Pseudælurus . $77,80,118$ intrepidus.

114,116

Pseudolabis. dakotensis

103,110

Pseudopterodon.

103

Pseudotomus........................ 57,101

hians........................... 97

robustus.......................... 97

superbus

97

sp........................... 97,99

Psittacotherium...................... 102

multifragum....................... 92

Ptilodus ............................. 100

mediævus......................... 91

trouessartianus....................... 91

Puerco formation, fauna of. . ....... 33-34,91-92 homotaxis of . ................... 22,33 figure showing................. 23

Putorius....................... 80, 89, 90, 118 nambianus.

Quercus

R.

Rangifer.

Rattlesnake, Oreg., fauna near......... 115-118

Rattlesnake formation, homotaxis and fauna of . . . . . . . . . . .

Reithrodontomys................... 90

Republican River, deposits on .......... $\quad 80$ fauna of ....................... 115-118

Rhinocerotidæ ........................ 30, $57,59,61,62,63,64,66,68,73,74,76,78,80$, $81,82,85,104,105,108,111,113,114,116,118$

Rhinocerotoidea............... 52, 54, 68, 69, 77

Rocky Mountains. See Mountain Region.

Rodentia............... 33, 36, 38, 40, 46, 52, 54, $55,56,57,58,59,61,63,64,66,68,73,74,75$, $77,78,80,81,85,89,90,94,97,99,101,103-$ $104,105,107-108,112-113,114,116,118-119$

Rosebud formation, distribution of, plates showing..

homotaxis and fauna of ........... 70,75 homotaxis of, figures showing. . ..... 23, 64, 70 Rosebud River, S. Dak., fauna near ...... 112-114 Rupricaprinæ
S.

Page.

Sage Creek, Mont., fauna of. . . . . . . . . 98-100

Salix.......................... 78

Samwel cave, Cal., fauna of.............. $\quad 89$

San Juan basin, N. Mex., fauna of ....... 35, 91-95 section of, figure showing............. 23

Sannoisien étage, homotaxis and fauna of. . . . 60-61

Santa Fe, N. Mex., fauna near ......... 115-118

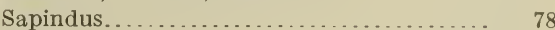

Sarcolemur....................... 38, 98, 103 furcatus......................... 98

pygmæus........................... 98

Sarcothraustes....................... 101

antiquus........................ 91

Sarmatien étage, homotaxis and fauna of.... $76-78$

Scalops........................... 90

Sciuravus.................. 44, 46, 59,61, 101 buccatus........................ 94

depressus......................... 94

minimus.......................... 97

nitidus........................ $\quad 97$

parvidens.......................... 97

undans............................ 97

sp.............................. 97

Sciuridæ.. 55, 61, $66,80,103,105,107,110,114,116,118$

Sciurus........................... 90,118

arctomyoides..................... 116

sp................................. 114

Scott, W. B., papers by ................. 12, 16

Scudder, S. H., papers by .............. 16, 18

Selenodonta........................ 52,57

Shufeldt, R. W., paper by ................ 18

Sigmogomphius lecontei ................. 116

Sinclair, W. J., faunal lists by . . . . . . . . . . 67

on Potter Creek cave................. 88

on volcanic ash .................... $\quad 25$

papers by .................. 12, 17, 18,19

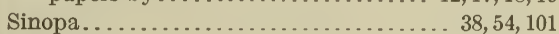

grangeri........................ 96

hians........................... 93

major............................. 96

minor............................. 96

multicuspis . . . . . . . . . . . . . . . . . . 93

opisthotoma...................... 93

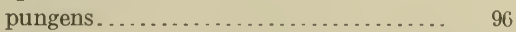

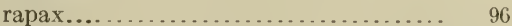

strenua.......................... 93

virerrina.......................... 93

sp............................. 93

Smilodectes........................... 100

gracilis.......................... 95

Smilodontopsis ....................... 87,90

Solenodon ............................ 61

Sorex............................... 90

Soricidæ...................... 52, 105, 110

South Dakota, badlands of, bird's-eye view

of $\ldots \ldots \ldots \ldots \ldots \ldots \ldots \ldots . .64$

fauna of ....................... 106-109

formations in, homotaxis of........... 22

homotaxis of, figure showing........ 23,65

Oligocene and Miocene in, map showing . $\quad 60$ Sparnacien étage, homotaxis and fauna of... 36-42 Spermophilus......................... 90 Spilogale......................... 89,90 Staked Plains, Texas, section of, figure showing...................... 82 Stampien étage, homotaxis and fauna of... 60-63 
Stegodon.

Stehlin, II. G., on European-American correlation.....................

Stenacodon. rarus.

Stenomylus gracilis.

Steneofiber. barbouri.

brachyceps.

complexus.

fossor.

gradatus

hesperus.

montanus.

nebrascensis.

pansus.

peninsulatus.

sciuroides.

simplicidens

Stenomylus.

Sternberg, C. H., paper by.

Stibarus.

montanus.

obtusilobus

quadricuspis.

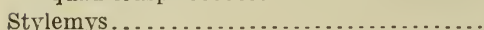

Stylinodon.................... 45, 46, 52, 102 cylindrifer. mirus $30,64,68,70,73,74,75,110,118$

Page. 82 39 103

tylinodontidæ.

Subhyracodon copei .

occidentalis.

simplicidens

sp. .

Suoidea.

Swiftcurrent Creek Canada, fauna of ...... 103-104 Symborodon

acer...

montanus. torvus.

Symbos...

Syndyoceras .

cooki......
Synoplotherıum lanius.

$34,40,92,94,97,102$

stemodon. .

primævus .

protapirinus.

semihians.

tapirinus.

\section{T.}

Tæniodonta ..... 33, 34, 35, 40, 45, 46, 52, 92, 94, 97, 102 Tagassuidæ. . . ............ 113, 115, 117,119, 120 Talpa.. platybrachys

Talpavidæ.

Talpavus.... nitidus.

Talpidæ..

Tamias...

Tapiravus.

rarus.....

validus

sp.
Page.

Tapiridæ........................ 40,46,

$52,54,57,60 ; 61,62,63,64,66,67,68,78,80,86$,

$87,90,94,98,99,102,106,108,111,115,116,119$

Tapirus............................ 87, 89

Taxidea............................ $\quad 89$

Taxodium............................ $\quad 78$

Taxymys........................... 101

lucaris......................... 97

Teleoceras.................. 69, 78,80, 81, 119

aurelianensis..................... $\quad 77$

crassus........................... $\quad 116$

fossiger.......................... 116

medicornutus ...................... 114

sp.............................. 114

Teleoceratinæ................. $76,77,80,81$

Telmalestes........................... 100

Telmatherium....................... 102

cultridens...................... 98

diploconum..................... 99

hyognathum................... 98

megarhinum...................... 98

validum.......................... 98

vallidens....................... 98

sp............................... 99

Telmatolestes crassus................... 95

sp............................... 95

Temnocyon.......................68, 110

altigenis........................ 107

ferox........................... 107

wallovianus. . ..................... 107

Tephrocyon.......................... 118 rurestris............................ 114

Tertiary deposits, homotaxis of........... 22

homotaxis of, figure showing......... . $\quad 23$

time scale for. ..................... 29-33

Tertiary history, outline of . ............. 19-28

Testudinata...................... 57,66

Testudinidæ........................... 58

Testudo.......................66, 72,74, 83

brontops ......................... 58

Tetraclænodon. See Euprotogonia.

Texas, formations in, homotaxis of, figures showing ...................65, 82

Thanétien étage, homotaxis and fauna of . . . 33-35

Thinocyon........................ 100 medius........................... 96

velox. . ......................... 96

sp................................ 96

Thomomys......................... 85

Thompson Creek, Mont., fauna of........ 103-104

Ticholeptus......................... 78, 119

bannackensis ..................... 115

brachymelis...................... 115

breviceps.......................... 115

zygomaticus ....................... 115

Ticholeptus zone, fauna of ........... 114-115 homotaxis of . . . . . . . . . . . . . . $76-77$

figure showing ................. 23, 65

Tillodontia.............45,46,51,52,94,97, 101

Tillomys........................... 101 parvus.......................... 97

senex............................ 97

Tillotherium.. .............. 49,50,52,97, 101

fodiens......................... 97

hyracoides . ..................... 97

latidens. . . . . . . . . . . . . . . . . . . . 97

sp.......................... 49,97 . 
Tinoceras. See Uintatherium.

'Titanotheriidæ..................... 25, 41, $43,46,48,52,54,57,60,61,95,98,99,102,104,111$

Titanotherium ................... $61,62,111$ helocerus....................... 104 ingens.......................... 104 prouti........................... 104 trigonoceras...................... 104

Titanotherium zone, fauna of. ..... 60-61, 103-104 homotaxis of . .................... 22, 60 figure showing........... 23, $62,64,65$

Tomarctus .......................... 118 brevirostris...................... 114

Tongrien étage, homotaxis and fauna of. ... 60-63 Torrejon formation, fauna of.... . . . 34-35,91-92 homotaxis of.................... 22,34-35 figure showing................. 23

Tortonien étage, homotaxis and fauna of .... $76-78$

Tricentes........................... 101 crassicollidens.. .................. 91 subtrigonus.................... 91

Trigenicus.......................... 111 mammifer......................... 104 socialis........................ 104

Trigonias.......................... 111 osborni........................ 104 sp............................... 104

Trigonolestes.................... 38,48, 103 brachystomus .................... 95 chacensis........................ 95 metsiacus...................... . 95 nuptus........................... 95 secans.......................... 95 sp.............................. 49

Trigonolestidæ........................ 95

Triisodon........................... 35, 101 gaudrianus....................... 91 heilprinianus..................... 91 quivirensis........................ 91

Triisodontidæ.................... 90,91, 101

Triisodontinæ........................ 33, 34

Trilophodon........................... 78, 119

angustidens..................... 80

campester...................... 81,116

euhypodon ...................... 81,116

floridanus....................... 116

præcursor........................ 116

productus........................ 116

shepardii........................ 120

Trionyx.............................. 47

Triplopus............................. 102

amarorum....................... 97

cubitalis.......................... 97

obliquidens. ..................... 99

Tritemnodon..................... 44, 45, 100 agilis........................... 96 whitiæ... ......................... 93

Trogosus........................ 52, 97, 101 castoridens....................... 97 minor........................ 97

Twelvemile Creek, Kans., fauna of......... 88

$$
\mathrm{U} \text {. }
$$

Uinta basin, deposits of.

$54-57$ fauna of .......................... $98-100$

Uinta formation, distribution of, map showing........................ homotaxis of, figures showing. .
Vintacyon...................... 93,100

bathygnathus................. . 96

$\operatorname{edax} \ldots \ldots \ldots \ldots \ldots \ldots \ldots \ldots \ldots . . . \ldots \ldots$

massetericus. . ...................... 93

promicrodon....................... 93

scotti.......................... 98

vorax........................... 96

sp............................ 96

Uintatheriidæ............... 42, 45, 52, 57,94, 97

Uintatherium ................ 51,52,53,102

(Tinoceras) affinis................ 97

(Dinoceras) agreste................ $\quad 97$

(Tinoceras) anceps.................. 97

(Tinoceras) annectens .............. 97

(Tinoceras) crassifrons............... 97

(Tinoceras) grandis. . . . . . . . . . . . . . . 97

(Tinoceras) hians. ................ 97

(Tinoceras) ingens. ............... $\quad 97$

(Dinoceras) laticeps. . . . . . . . . . . . . 97

latifrons........................ 97

leidyanum. ..................... 97

(Tinóceras) longiceps............... 97

(Dinoceras) lucare.................. 97

(Dinoceras) miralbile . .............. $\quad 97$

(Tinoceras) pugnax .............. 97

robustum....................... 97

spierianum......................... 97

(Tinoceras) stenops. . . . . . . . . ..... 97

(Tinoceras) vagans................ 97

sp............................. 97

Uintatherium zone, fauna of. .... 49-54, 55-57, 95-98 homotaxis of . ......... 22, 42, 49-50,53,54-55

figures showing............ 23,51,53,55

Ungulata........... $35,40,42,46,52,54,57,61,84$

United States, map of, showing fossil locali-

ties....................... 7

Upper Brule Creek, S. Dak., fauna of ..... 106-109 Urocyon........................... 89, 90

Ursidæ...................... $64,85,86,89,90$

Ursus........................ 87,88,89,90

Utah, fauna of ...................... 98-100

formations of, homotaxis of ........... 22 homotaxis of, figure showing...... 23

\section{V.}

Vassacyon.......................... 100

promicrodon...................... 93

Veatch, A. C., on volcanic ash............. 25 paper by ......................... 12

Vespertilio.......................... 90

Viverravus........................ 46,100 dawkinsianus.................... 49,93 gracilis.......................... 96 minutus........................... 96 sp .............................. 96

Viverridæ........................... 64

Volcanic ash, distribution of. ......... 22,24-25

Volcanoes, prevalence of................. 24

Vulpavus...................... 46,52, 100 brevirostris....................... 93

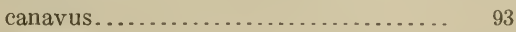

palustris ........................... 96 sp............................... 93,96

Vulpes............................. 89,90

W.

Wasatch formation, distribution of, map showing.................... 
Page.

Wasatch formation, fauna of. $36-42,92-95$ homotaxis of $\ldots \ldots \ldots \ldots \ldots \ldots . . \ldots \ldots+36-42$ figures showing.............. 23,38, 39

Washakie Basin, Wyo., deposits of........ 53-54 fauna of . . . . . . . . . . . . . formations of, homotaxis of, figures showing 23,53 history of....................... 53

WVashakius. .......................... 100 insignis......................... 95 sp.............................. 95

Washtucna Lake, Wash., fauna of......... 89

Weeks, F. B., papers by .................. 9

White Buttes, N. Dak., fauna of . . . . . . . . 106-109

White River group, fauna of . . . . . . . . . 103-111 homotaxis of . . . . . . . . . . . . . . . . $60-61$ figure showing. . . . . . . . . . . . . 23, 62

Williston, S. W., papers by .............. 18

Wind River Basin, Wyo., formations of, homotaxis of, figure showing....

Wind River formation, distribution of, map showing..................... 37 fauna of ..................... . 43-48,92-95 homotaxis of .................... 43-48

Wortman, J. L., on Huerfano Basin ......... on volcanic ash.
Wortman, J. L., on Wind River formation. papers by

Wortman, J. L., and Cope, E. D., paper by.. 17 Wortman, J. L., and Osborn, H. F., papers by ...................... 12, 16

Wortmania........................... 102 otariidens......................... 92

Wyoming, fauna of............ 92-100,103-109 formations in, homotaxis of, figures showing........................ 23,65 geologic map of...................... $\quad 37$ Oligocene and Miocene in, map showing. $\quad 60$

$\mathrm{X}$.

Xenotherium........................ 110

unicum......................... 103

Y.

Yprésien, homotaxis and fauna of . ....... 36-50

\section{Z.}

Zeuglodon............................ 20

Zeuglodon zone, mammals of . . . . . . . . . . . 20

Zone, definition of................... 7

Zones, mammalian, diagrammatic section showing.................... 
. 



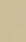






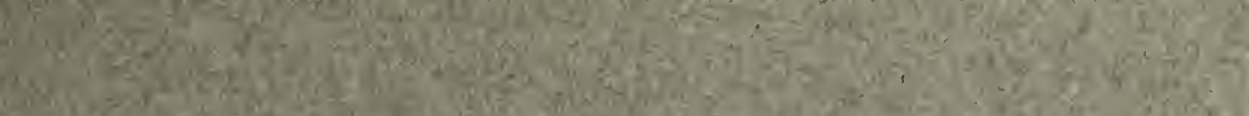

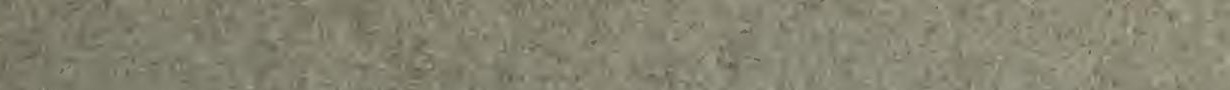

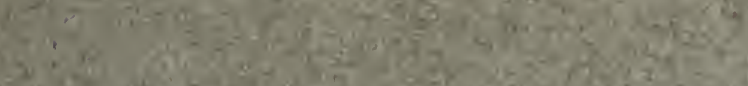

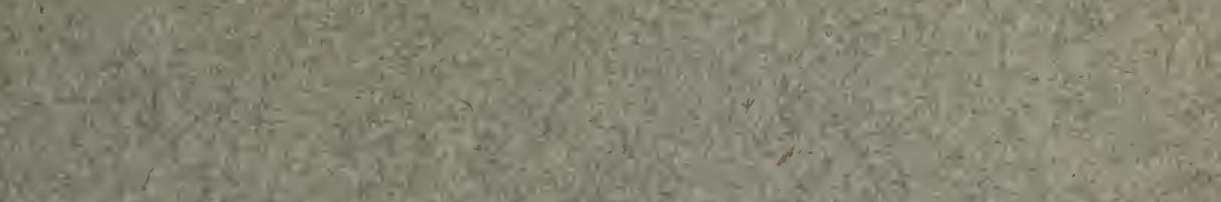

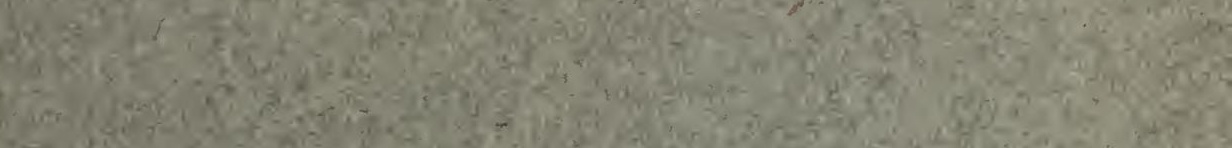

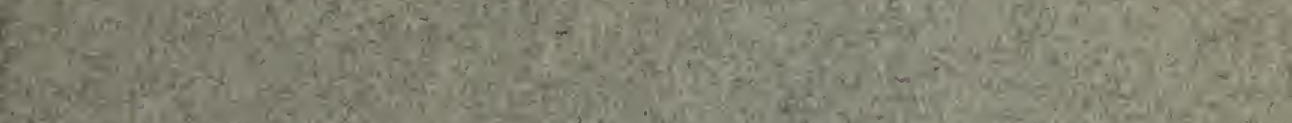

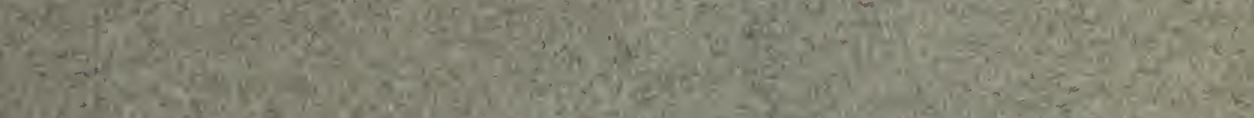

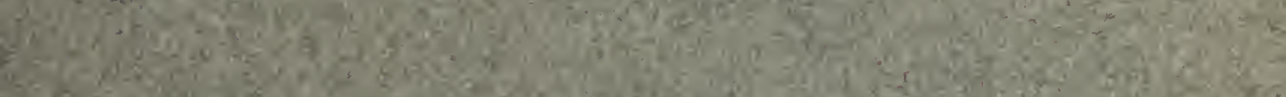

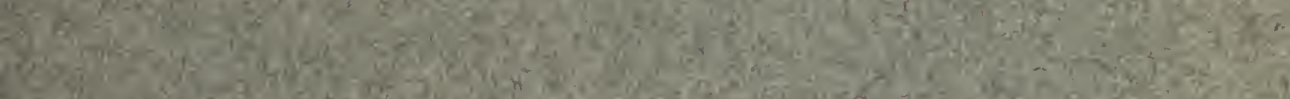

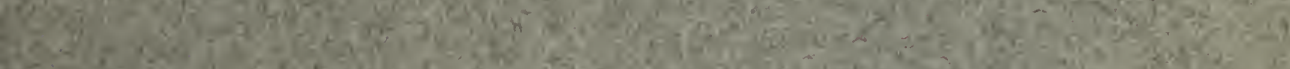

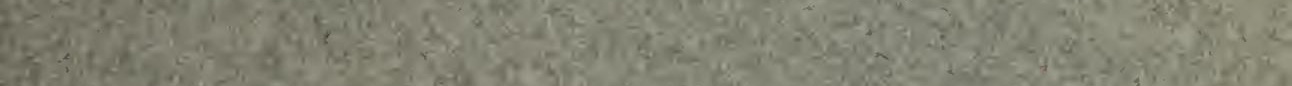

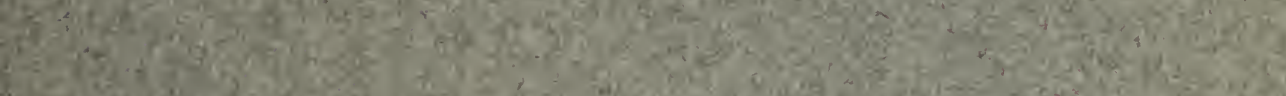
a.

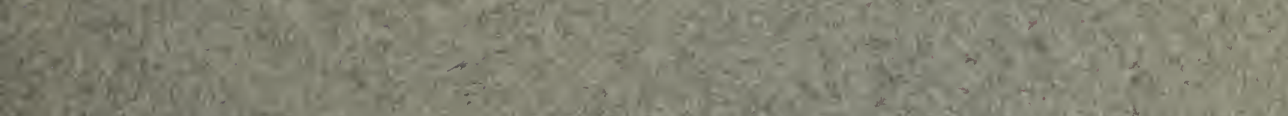
Q.

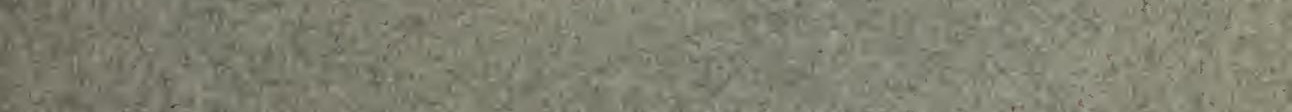

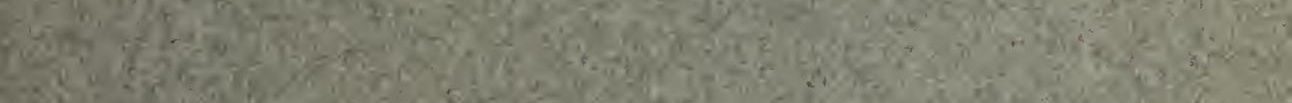

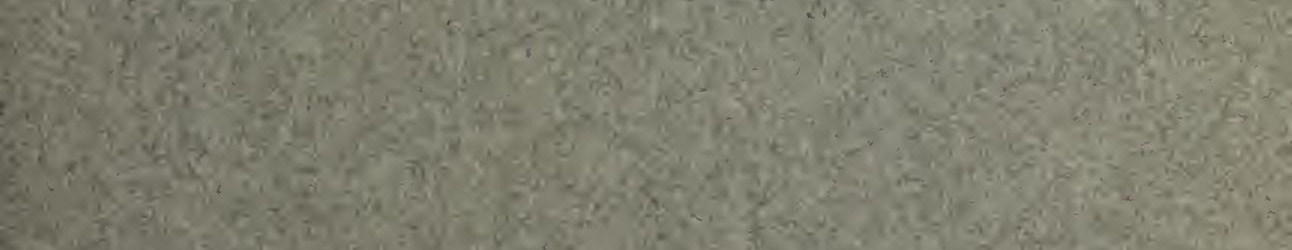

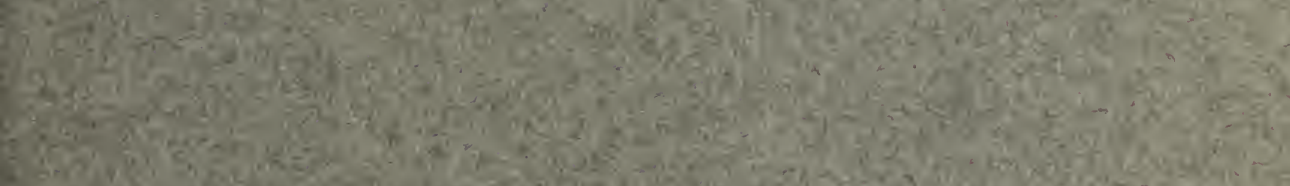

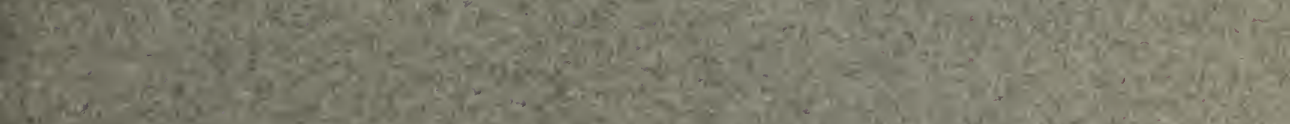

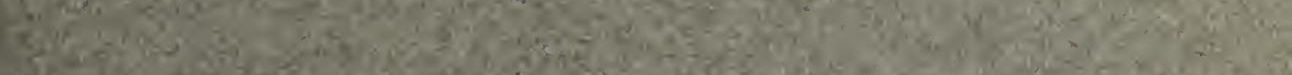

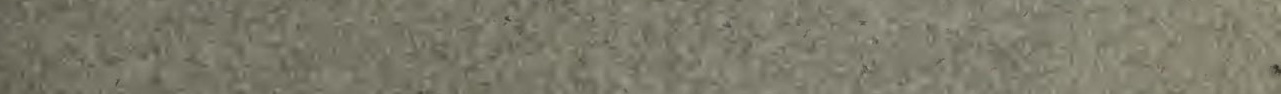

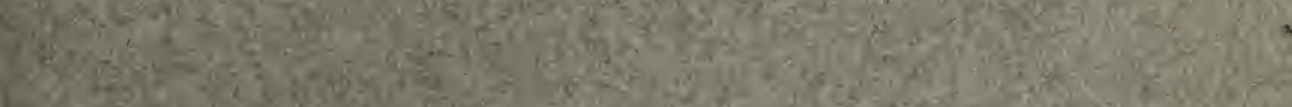

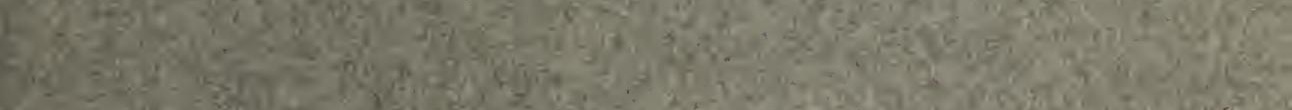

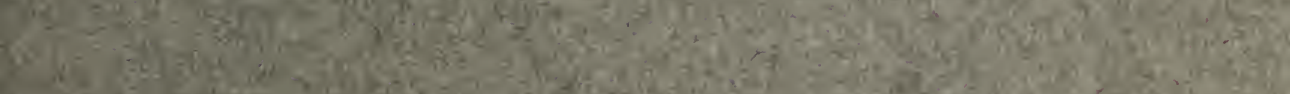

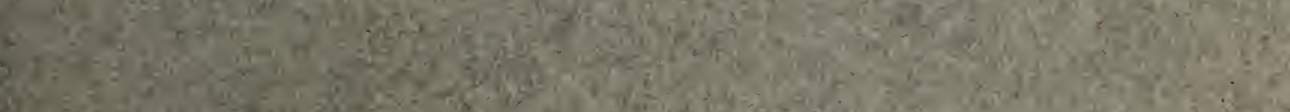

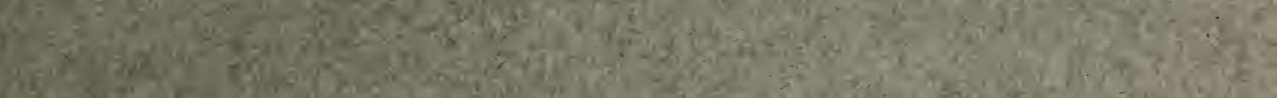

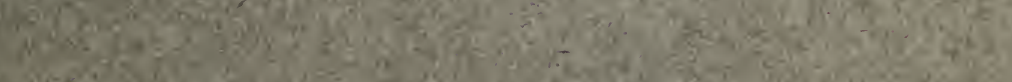




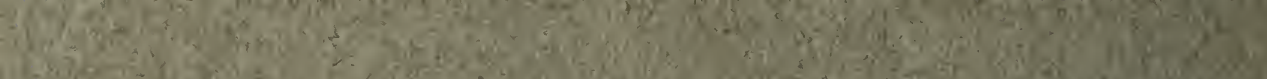

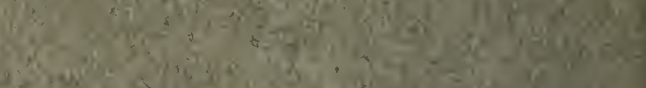

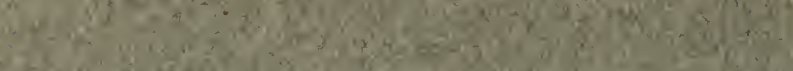

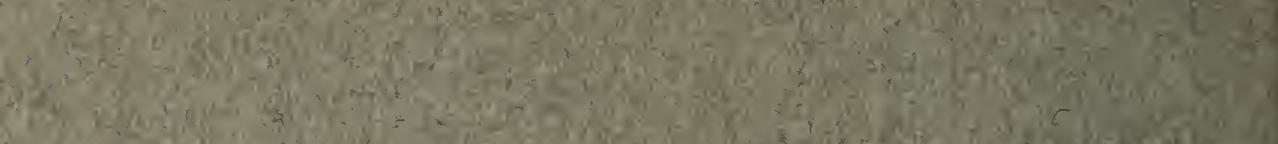

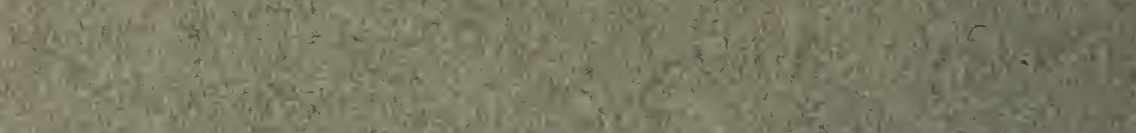

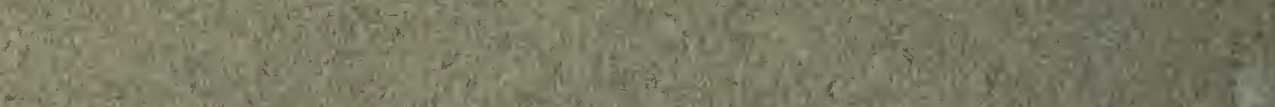

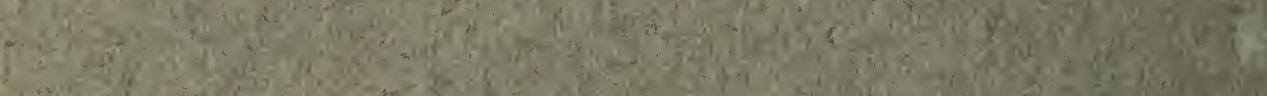
Novis 1
1

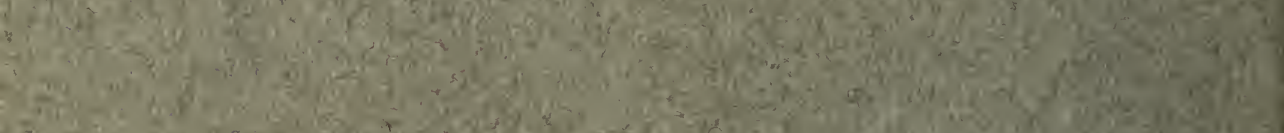

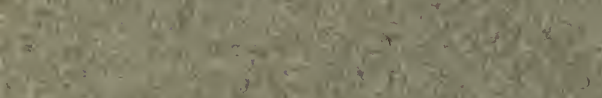

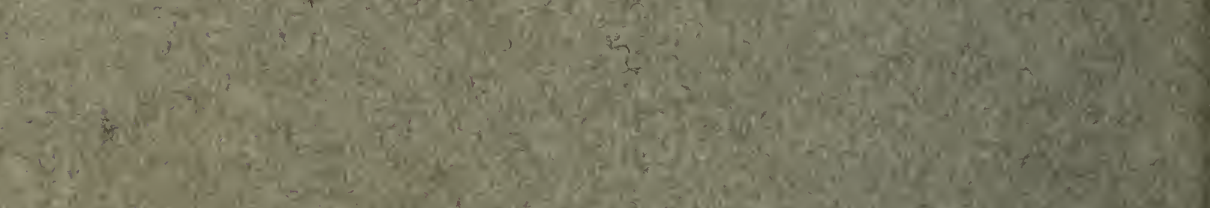

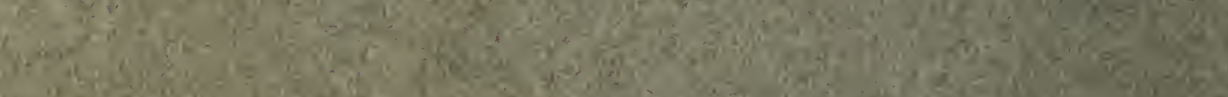

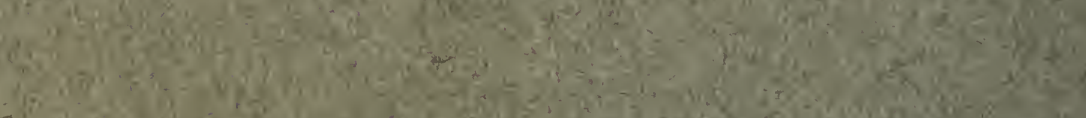

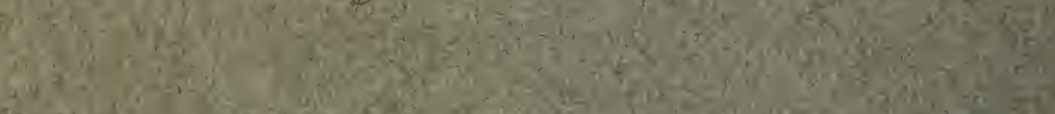

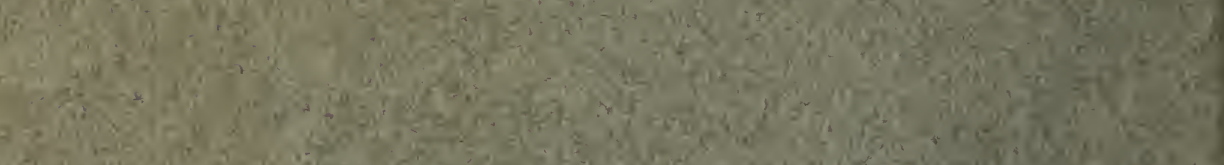

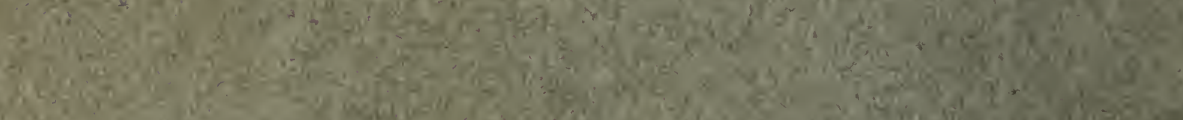

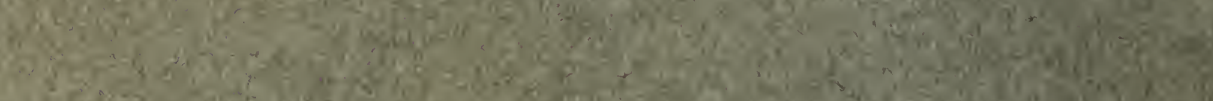

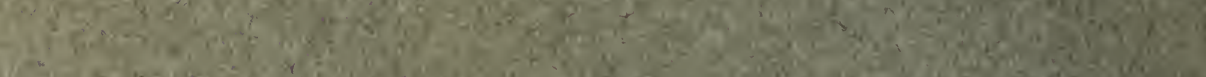

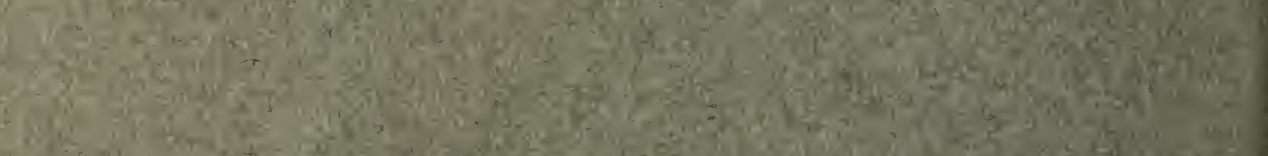

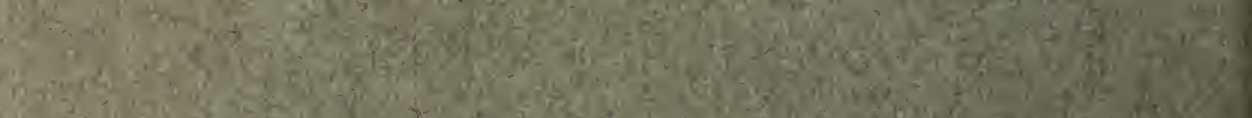

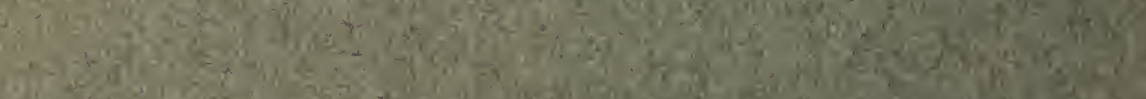

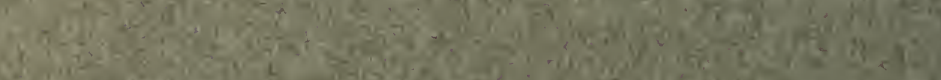
W.

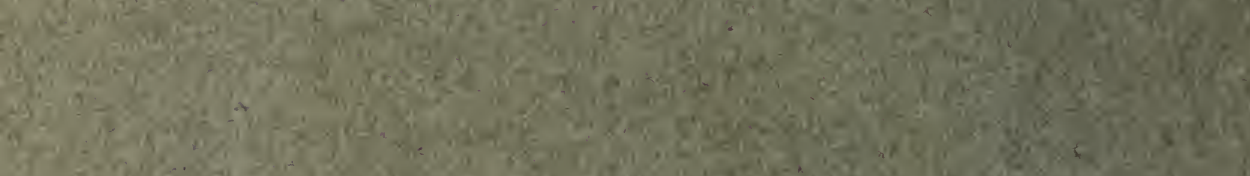

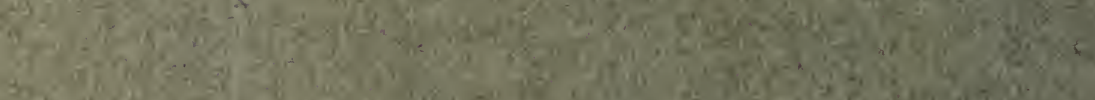

\begin{tabular}{l}
$3 y^{2}$ \\
\hline
\end{tabular}

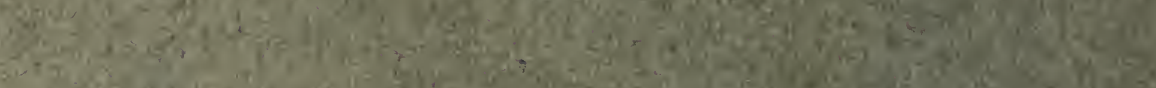

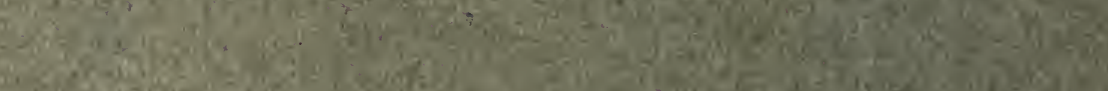

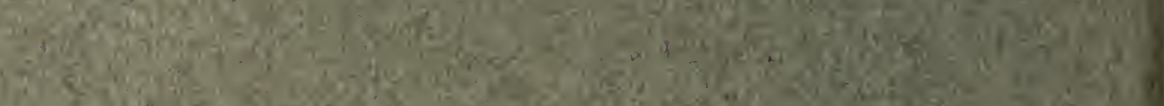
Q.

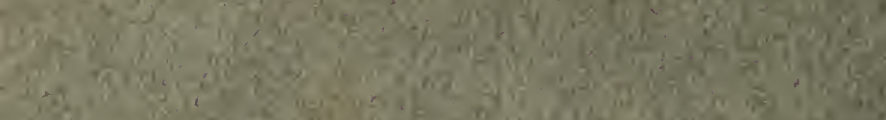

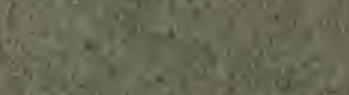

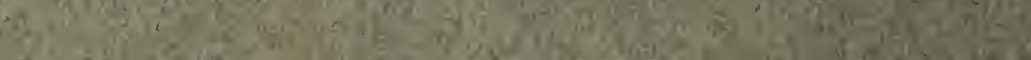

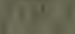




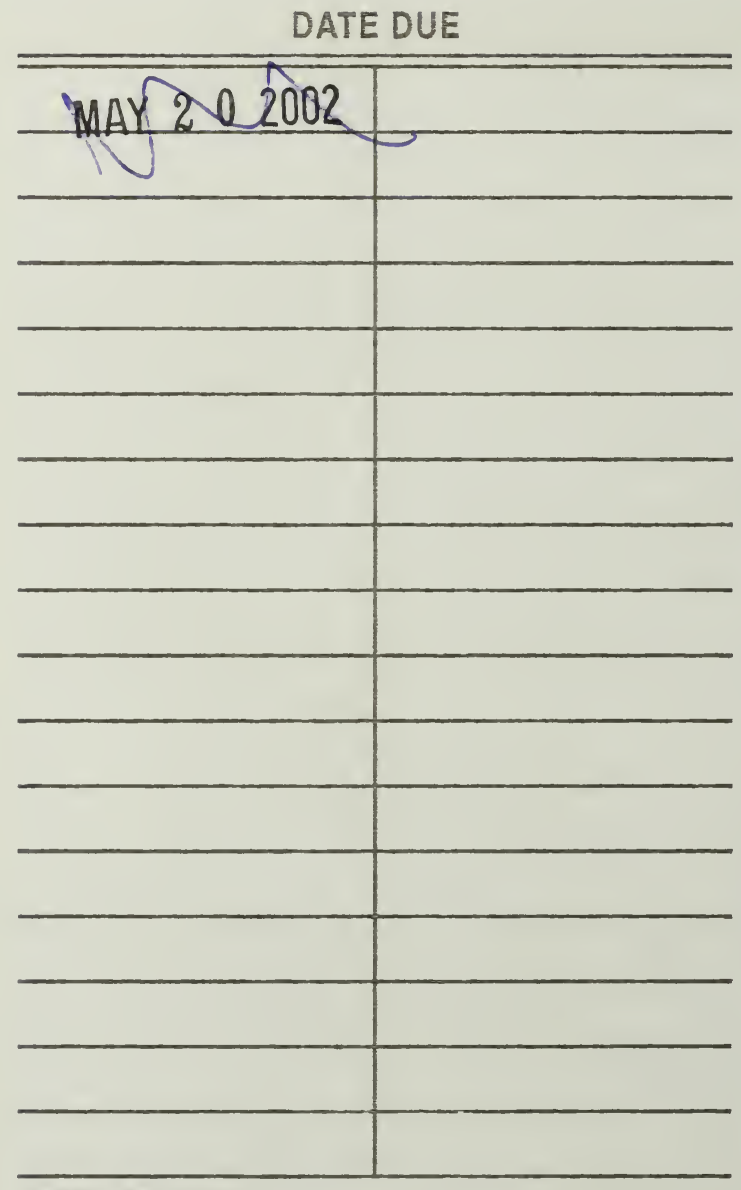

DEMCO, INC. 38-2931 
ERNST MAYR LIBRARY

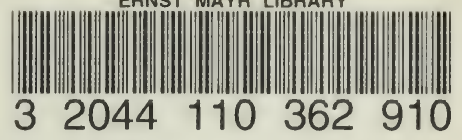


